University of Louisville ThinkIR: The University of Louisville's Institutional Repository

Electronic Theses and Dissertations

$5-2016$

\title{
Woody plant communities of three urban wetlands and the success of an invasive shrub (Lonicera maackii) over natural and experimental flooding gradients.
}

Meghan Rhea Langley

University of Louisville

Follow this and additional works at: https://ir.library.louisville.edu/etd

Part of the Terrestrial and Aquatic Ecology Commons

\section{Recommended Citation}

Langley, Meghan Rhea, "Woody plant communities of three urban wetlands and the success of an invasive shrub (Lonicera maackii) over natural and experimental flooding gradients." (2016). Electronic Theses and Dissertations. Paper 2475.

https://doi.org/10.18297/etd/2475

This Doctoral Dissertation is brought to you for free and open access by ThinkIR: The University of Louisville's Institutional Repository. It has been accepted for inclusion in Electronic Theses and Dissertations by an authorized administrator of ThinkIR: The University of Louisville's Institutional Repository. This title appears here courtesy of the author, who has retained all other copyrights. For more information, please contact thinkir@louisville.edu. 
WOODY PLANT COMMUNITIES OF THREE URBAN WETLANDS AND THE SUCCESS OF AN INVASIVE SHRUB (LONICERA MAACKII) OVER NATURAL AND EXPERIMENTAL FLOODING GRADIENTS

\author{
By \\ Meghan Rhea Langley \\ B.S., Centre College, 2004 \\ A Dissertation Submitted to the Faculty of the \\ College of Arts and Sciences of the University of Louisville \\ In Partial Fulfillment of the Requirements \\ for the Degree of
}

Doctor of Philosophy in Biology

Department of Biology

University of Louisville

Louisville, Kentucky

May 2016 
Copyright 2016 by Meghan Langley

All rights reserved 

WOODY PLANT COMMUNITIES OF THREE URBAN WETLANDS AND THE SUCCESS OF AN INVASIVE SHRUB (LONICERA MAACKII) OVER NATURAL AND EXPERIMENTAL FLOODING GRADIENTS

\author{
By \\ Meghan Rhea Langley \\ B.S., Centre College, 2004 \\ A Dissertation Approved on
}

June 3, 2016

by the following Dissertation Committee:

Dissertation Director

Dr. Margaret Carreiro

Dr. Christopher Barton

Dr. Gary Cobbs

Dr. Sarah Emery

Dr. Wayne Zipperer 


\section{DEDICATION}

This dissertation is dedicated to my parents

Robert Franklin Langley

and

Michele Mann Langley

for encouraging curiosity, valuing education and supporting me through all my academic endeavors. 


\section{ACKNOWLEDGEMENTS}

I offer sincere gratitude to the many people who contributed to my Ph.D. work with their advice, time, effort, and support. My committee chair, Dr. Margaret Carreiro provided her expertise, encouragement, lab space and financial support. I credit her and my current committee members_-Dr. Chris Barton, Dr. Gary Cobbs, Dr. Sarah Emery and Dr. Wayne Zipperer-with keeping me motivated and on the path to completion. Past members of my advisory committee (Dr. Hwa-Seong Jin and Dr. Clara Leuthart) also provided valuable insights. Dr. Jeff Jack, my former advisor, also deserves remembrance for accepting me into his lab and piquing my interest in wetland research before his untimely passing.

A number of graduate students, undergraduate students, friends and family members provided their assistance in the field: Kaycee Stone, David Warder, Allen Barnett, Melissa Barrett, Laura Kennedy, Eddie Alagna, Troy Tucker, Preston Pipal, Ayla Murrell, Gillian Langley, Allison Smith and Jeff Masters. They endured long days, mosquitos, and thickets of poison ivy. Kaycee, in particular, was instrumental to my research, providing assistance in both field research and the seedling growth experiment. Her reliability and thoroughness were essential to the success of these projects.

I would also like to thank the following people for their time, effort and expertise in various fields. Steve Blanford and Bob Eigel of the USDA Natural Resource 
Conservation Service provided soil descriptions at my research sites. Dr. Gary Cobbs spent a great deal of time meeting with me and providing expertise for the statistical analysis in Chapter 3. Dr. Susi Remold also consulted on statistical analysis. Adrian Camacho and Pat Haragan provided assistance with plant identification.

Through the generosity of Dr. Chris Barton and Dr. Wayne Zipperer, I was able to access valuable equipment that was essential to my research. Financial support was provided by the Kentucky Society of Natural History, University of Louisville, the Society of Wetland Scientists, and The Wetland Foundation.

My lab mates gave me much needed company and encouragement; thank you Allison Smith, Tara Trammell, Shannon Scroggins, Preston Pipal, Robbie Johnson, Jay McLeod, Jonathan White, Eli Levine, David Word, Wes Daniel, and Natalie Abram.

Finally, thank you to my family for your love and support. My parents, Robert and Michele Langley, wished and worked for their children to pursue educational opportunities that were not available to them. They instilled curiosity, skepticism, and creativity in all their children, and these values have been invaluable to my growth as a scientist. 


\title{
ABSTRACT \\ WOODY PLANT COMMUNITIES OF THREE URBAN WETLANDS AND THE SUCCESS OF AN INVASIVE SHRUB (LONICERA MAACKII) OVER NATURAL AND EXPERIMENTAL FLOODING GRADIENTS
}

\author{
Meghan R. Langley
}

June 3, 2016

Globally, wetlands are known for providing important ecosystem services that enhance the quality of human life and regulating global biogeochemical cycles. Despite the wide recognition of their value, temperate forested wetlands are the least protected type of ecosystem world-wide, and are threatened by human activities such as logging and development. The ecology of forested wetlands remaining in urbanized areas is impacted by a multitude of anthropogenic threats, including fragmentation (which decreases the amount of interior habitat and increases edge habitat), hydrologic modification (ditching and draining of wetlands) and the incursion of invasive species (which are frequently introduced by human activities).

In the first study presented in this dissertation (Chapter 2), I examined how woody plant communities of three urban wetlands - the dominant biota of these ecosystemschanged along edge-to-interior and hydrologic gradients. Detailed measurements of elevation, surface water levels, and ground water levels were made to estimate the number of days each transect was flooded. The three study forests were surveyed in transects along edge-to-interior gradients (0-60 meters from the forest edge) and were 
found to exhibit a gradient of flooding (measured as the number of days flooded in sampled areas). Ordination with non-metric multidimensional scaling (NMS) - using Importance Values (IVs) of adult trees, saplings, tree seedlings, shrubs and vines in transects at 1, 5, 10, 30 and $60 \mathrm{~m}$ from the edge-was used to see if patterns in the woody plant community related to distance from edge, number of days flooded and other environmental variables.

Distance from the forest edge and number of days flooded were the two variables shown to be most correlated with ordination axes generated from the species matrix $\left(r^{2} \geq 0.15\right)$, and each was associated with a different axis. The shrub community was most indicative of community differences along the hydrologic gradient (Axis 1); Lindera benzoin (a facultative shrub) and Cornus foemina (a facultative wetland shrub) were the species most associated with drier and wetter transects, respectively. The invasive shrub species, Lonicera maackii, was present at all sites, but more important at the two driest sites. Because the relative elevation (within a transect) of L. maackii plants increased with the number of days flooded, it appeared that higher elevation microsites may have provided refugia for the establishment and/or persistence of this invasive species in flooded areas. Fraxinus pennsylvanica (green ash) was a major component of the tree canopy species at all sites, and the imminent threat posed by the emerald ash borer (Agrilus planipennis) will most certainly result in the formation of large canopy gaps.

Following the findings of Chapter 2, two manipulated experiments were conducted to determine the degree to which L. maackii was impacted by flooding at early life history stages. In the first experiment (Chapter 3), seedlings of L. maackii were subjected to factorial treatment combinations of simulated canopy cover (2 levels), 
flooding duration (3 levels) and flooding depth (4 levels) in experimental mesocosms for 40 days. Flooding events were followed by a recovery period. Inundation and saturation of seedlings for 10 to 17 days had a markedly negative effect on honeysuckle seedlings as shown by slow vertical growth or dieback and loss of leaves. No seedlings inundated for 17 days survived.

In the second experiment (Chapter 4), I measured the germinability and mean germination time (MGT) of L. maackii seeds stratified under cool-moist, cool-saturated, or cool-inundated conditions and transitioned to a second set of conditions intended to mimic natural drawdown or flooding events. A constantly moist control was included. Only MGT, but not germinability, of moist-to-inundated transitions (a simulated flooding treatment) differed significantly from moist controls. Seeds subjected to simulated drawdown conditions did not differ from moist controls, indicating that seeds of $L$. maackii seeds can remain viable in flooded areas, and that temporary, winter flooding of wetland microsites may not impose a major limitation on L. maackii germination.

The results of these three studies underscore the threats posed by invasive plant and insect species to the native woody plant community of these study systems. Evidence from the field and mesocosm studies suggest that flooding does pose a barrier to L. maackii colonization, but that higher elevation "safe sites" (with shorter flooding durations and/or depths) may enhance the ability of this species to invade wetter areas. At the time of field data collection (2010), emerald ash borer was largely absent from these forests, but has now caused widespread tree death in the region. Because Lonicera maackii is known to benefit from increased light availability, the opening of the tree 
canopy could have a beneficial effect on the spread of this invasive plant species within wetland sites. 
TABLE OF CONTENTS

PAGE

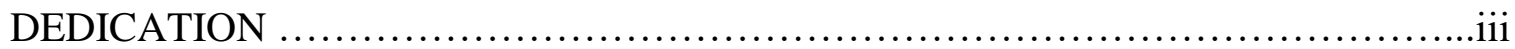

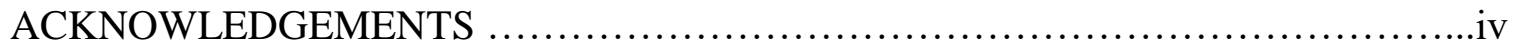

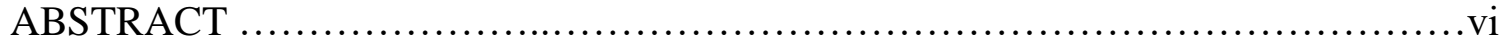

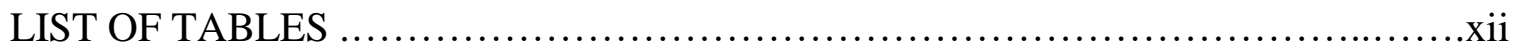

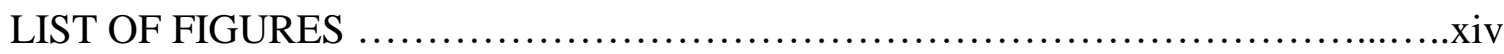

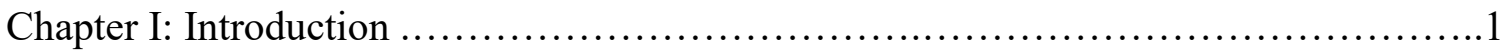

Chapter II: Patterns of Woody Plant Communities Over Hydrologic and Edge-To-Interior

Gradients: A Study of Three Urban Wetlands.............................5

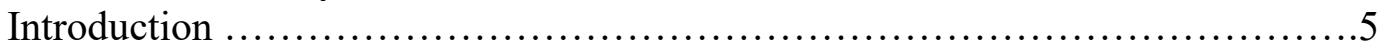

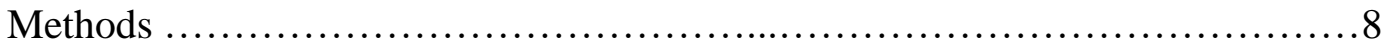

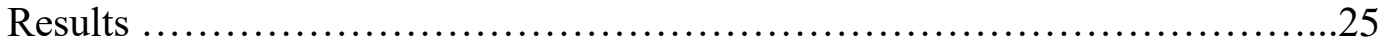

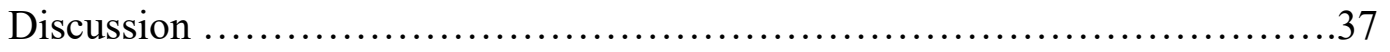

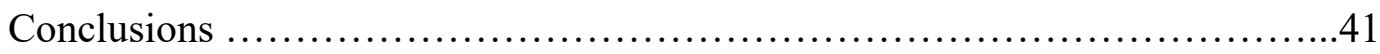

Chapter III: Effects of Flooding Duration, Flooding Depth and Light on the Growth and Survival of Lonicera Maackii in an Experimental Mesocosm ..................67

Introduction ..........................................................67

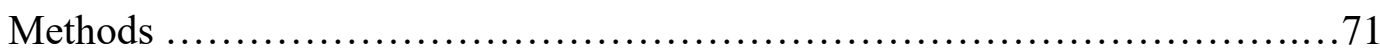

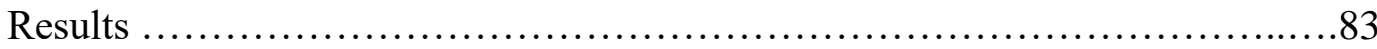

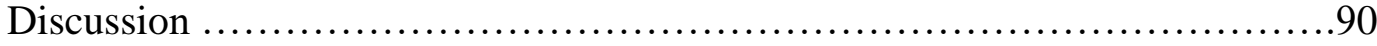

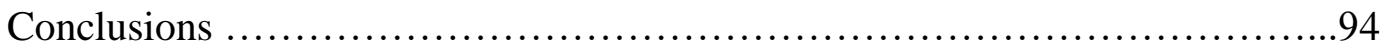

Chapter IV: Effects of Simulated Flooding on Germination of Lonicera Maackii

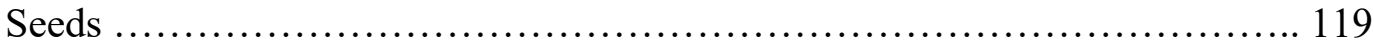

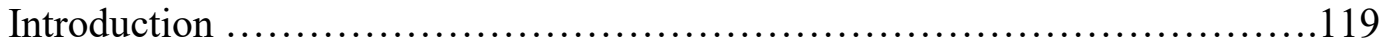

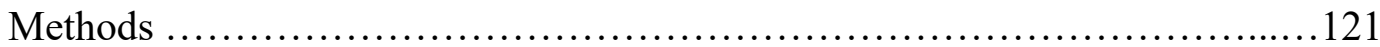

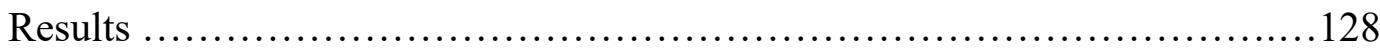

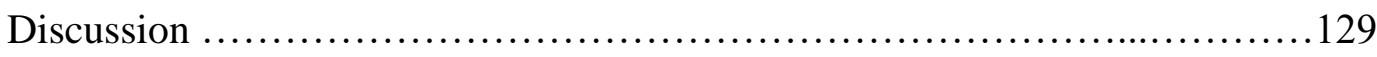

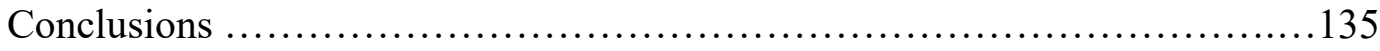

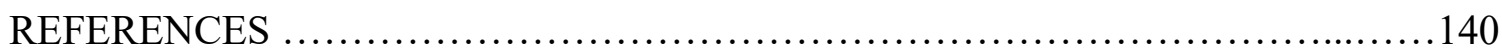

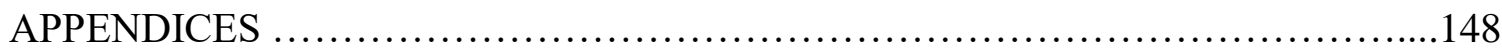

Appendix Table 1 ................................................... 148

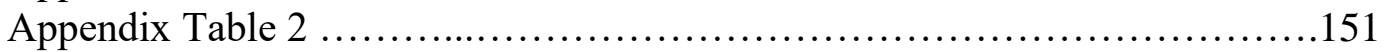

Appendix Table 3 ..................................................... 152 


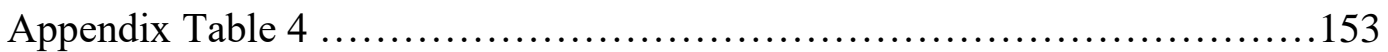

Appendix Table 5 ......................................................... 154

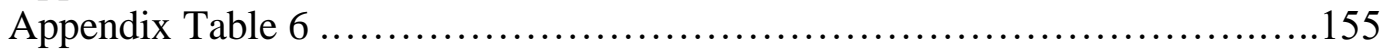

Appendix Table 7 .................................................... 158

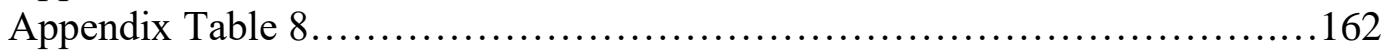

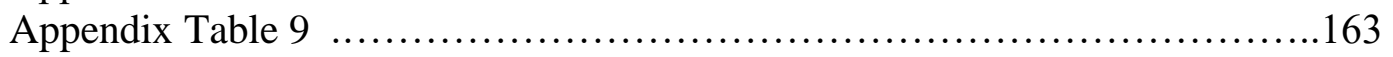

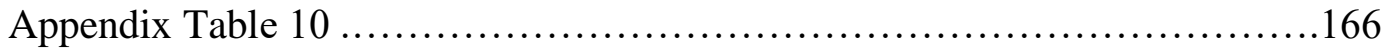

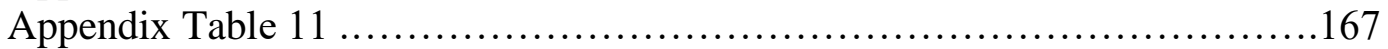

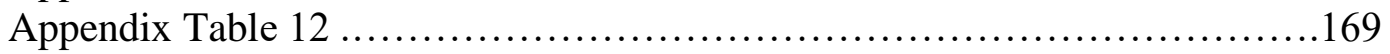

Appendix Table 13 .................................................... 170

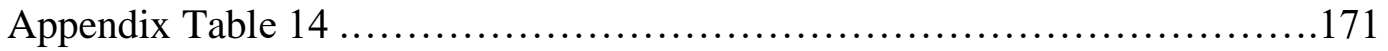

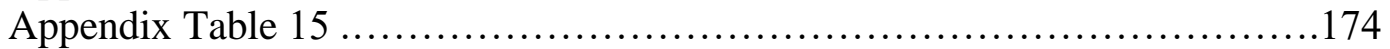

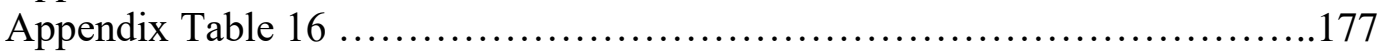

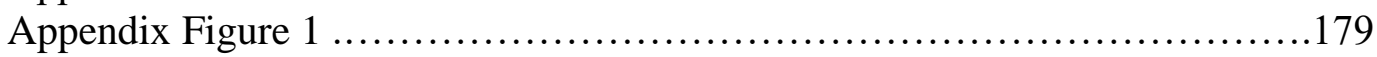

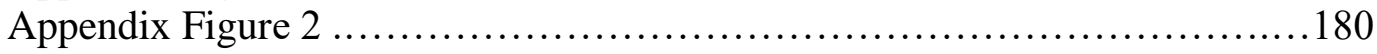

Appendix Figure 3 .................................................... 181

Appendix Figure 4 .................................................... 182

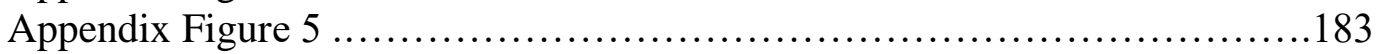

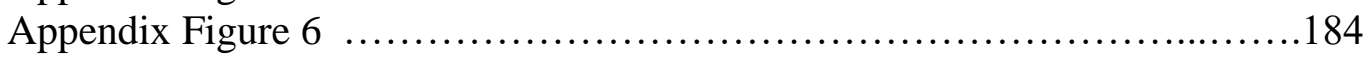

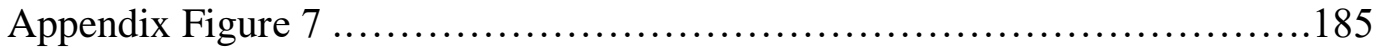

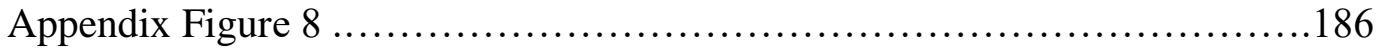

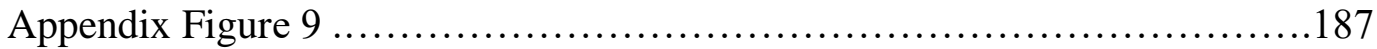

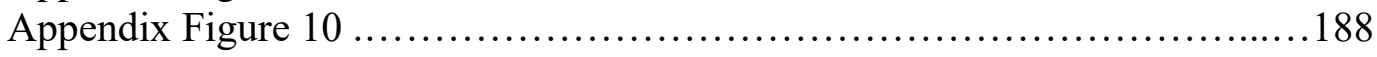

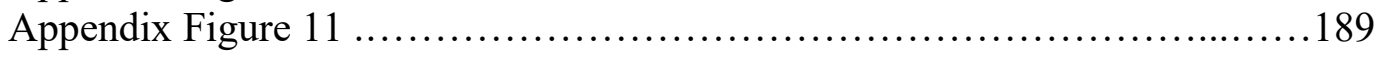

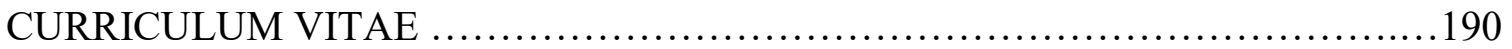




\section{LIST OF TABLES}

Table 2-1: Summary of research site characteristics ..............................42

Table 2-2: Number of days flooded for edge-to-interior transects and sites ............. 43

Table 2-3: Summary of environmental variables in edge-to-interior transects ...........44

Table 2-4: Correlations between environmental variables ............................45

Table 2-5: Density, Importance Values and basal area of adult trees by site .............46

Table 2-6: Species richness and diversity measures for all vegetation layers ............48

Table 2-7: Density, Importance Values and frequency of tree saplings by site ...........49

Table 2-8: Density, Importance Values and frequency of tree seedlings by site ...........50

Table 2-9: Density, Importance Values and frequency of shrub species by site ...........51

Table 2-10: Density, Importance Values and frequency of shrub species by site .........52

Table 2-11: Summary of environmental and biotic and environmental variables

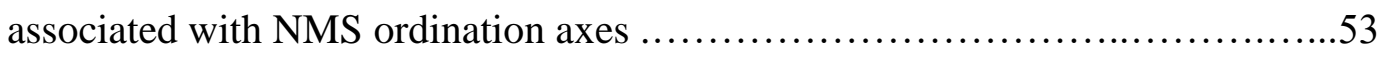

Table 2-12: Correlation data for relationships between days flooded, total shrub stem density, and stem density of important shrub species ........................55

Table 3-1: Results of mixed model regression testing effects of experimental variables on plant growth response of Lonicera maackii seedlings ............................96

Table 3-2: Results of mixed model regression testing effects of experimental variables on leaf number response of Lonicera maackii seedlings ..........................97

Table 3-3: Mean, minimum and maximum days lived of Lonicera maackii seedlings for all combinations of flooding depth and flooding duration ......................98

Table 3-4: Results of mixed model regression testing effects of experimental variables on final aboveground biomass of Lonicera maackii seedlings .......................99

Table 3-5: Results of mixed model regression testing effects of experimental variables on final belowground biomass of Lonicera maackii seedlings ........................ 100 
Table 3-6: Results of mixed model regression testing effects of experimental variables on final root-shoot ratio of Lonicera maackii seedlings .........................101

Table 4-1: Summary of stratification and post-stratification treatments for all five treatment groups in germination assay

Table 4-2: Means of mean germination time (MGT) for all flooding treatments and moist controls .......................................................... 138

Table 4-3: Means of total seed germinability for different flooding treatments ..........139 


\section{LIST OF FIGURES}

Figure 2-1: Layout and dimensions of sampling units ..........................55

Figure 2-2: Visual aid explaining terms used in quantifying site hydrology .............56

Figure 2-3: Hydrographs depicting water levels in water monitoring wells in each of the three research sites....................................................... 57

Figure 2-4: Seedling density of important species in north and south-facing edges with

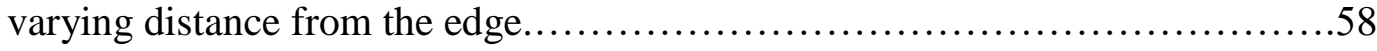

Figure 2-5: Mean stem density of the four most abundant shrub species, at each site....59

Figure 2-6: Height class distribution of Lonicera maackii stems at each site.............60

Figure 2-7: Total percent cover of Lonicera japonica vines with distance from the forest edge at all three research sites....................................................61

Figure 2-8: Biplot of environmental variables with NMS ordination axes 1 and 3 based on woody plant species Importance Values (IVs) in all sampling units (parallel transects) from all three study sites.................................................62

Figure 2-9: Biplot of biotic variables with NMS ordination axes 1 and 3 based on woody plant species Importance Values (IVs) in all sampling units (parallel transects) from all three study sites........................................................63

Figure 2-10: Biplot of biotic variables with NMS ordination axes 1 and 2 based on woody plant species Importance Values (IVs) in all sampling units (parallel transects) from all three study sites.....................................................64

Figure 2-11: Stem densities of dominant shrub species vs. days flooded in parallel transects across all sites..................................................65

Figure 2-12: Factor-ceiling distribution of the number of days flooded vs. the rank elevation of all Lonicera maackii individuals sampled. .66 
Figure 3-1: Graphical summary of split-split plot experimental design, showing nested structure of variables..................................................... 102

Figure 3-2: Photographs illustrating construction of outdoor mesocosms..............103

Figure 3-3: Graphical summary of split-split plot design for each experimental tank....104

Figure 3-4 Illustration of flood depth and flood duration manipulations...............105

Figure 3-5: Daily fluctuation in temperature for soil, water and air in experimental mesocosms, as measured on a single date............................... 106

Figure 3-6: Mean observed vs. predicted growth curves for seedlings over the duration of the experiment................................................. 107

Figure 3-7: Stem growth response of seedlings subjected to different flooding depths for three days over the duration of the experiment.......................... 108

Figure 3-8: Stem growth response of seedlings subjected to different flooding depths for ten days over the duration of the experiment................................ 109

Figure 3-9: Stem growth response of seedlings subjected to different flooding depths for seventeen days over the duration of the experiment...........................110

Figure 3-10: Mean observed vs. predicted curves for change in seedling leaf number over the duration of the experiment. 111

Figure 3-11: Change in leaf number for seedlings subjected to different flooding depths for three days over the duration of the experiment

Figure 3-12: Change in leaf number for seedlings subjected to different flooding depths for ten days over the duration of the experiment 113

Figure 3-13: Change in leaf number for seedlings subjected to different flooding depths for seventeen days over the duration of the experiment 114

Figure 3-14: Mean aboveground biomass for all combinations of light, flood depth and flood duration.

Figure 3-15: Interaction plot showing final mean aboveground biomass of surviving seedlings for all combinations of light, flood depth and flood duration..........116

Figure 3-16: Mean belowground biomass for all combinations of light, flood depth and flood duration. 
Figure 3-17: Mean root-shoot-ratio for all combinations of light, flood depth and flood

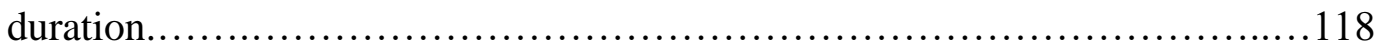

Figure 4-1: Mean daily temperature in experimental germination chamber from days

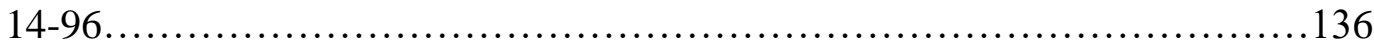




\section{CHAPTER I}

\section{INTRODUCTION}

Wetlands, in their many forms, are recognized as some of the most important ecosystems in the world. According to Costanza et al. (1997), per unit of area, wetland ecosystems are the most valuable terrestrial ecosystem globally, because of the multitude of ecosystem services they provide. In a review of ecosystem services in urban areas, urban wetlands were the only ecosystem type regarded by Bolund and Hunhammar (1999) as providing all identified services, including air filtration, regulation of microclimate, regulation of rainwater drainage, waste treatment, and cultural/recreational values.

While benefits of wetlands are recognized by the scientific community, these ecosystems continue to be threatened as a result of both direct and indirect human activities. Only $3.9 \%$ of the world's temperate forested wetlands are protected; this is the lowest figure for any forest type globally (Schmitt et al. 2009). Although legislation in the United States strictly regulates the development and draining of wetlands, wetland losses continue. From the 1950s through the mid-80s over 9 million acres of freshwater forested wetlands were lost from the conterminous United States (Dahl 2016). For approximately two decades thereafter, promising gains were made, and forested wetland area increased. Unfortunately, from 2004-2009, this trend saw a reversal, with losses of over 600,000 acres $(1.2 \%)$ of forested wetland. Urbanization accounted for 
$26 \%$ of losses during this time period. Since this type of conversion generally involves draining, filling and building on wetlands, these represent permanent losses of wetland area and their associated ecosystem services.

Remnant wetlands in urbanized areas face a number of threats. Urban forests are likely to be highly fragmented because of their association with high road densities and development, thus decreasing the amount of forest interior. Wetland forest fragments in urbanized areas must contend with the combined threats of air, soil, and water pollution, invasive species, altered hydrology, and the urban heat island effect, each of which has the potential to affect the survival, growth, reproduction and distribution of wetland flora and fauna, and can affect the ability of wetlands to perform ecosystem services (Faulkner 2004).

Many aspects of the urban environment mirror changes in climate, disturbance

regimes, and species movements that are currently occurring at a global scale (Carreiro \& Tripler 2005). Thus, study of urban wetlands may be seen as an opportunity to "flashforward" and make predictions about the future condition of forests that may be increasingly affected by human activities, invasive species, and global climate change.

\section{Personal Reflections and Dissertation Objectives}

Recognizing both the value and scarcity of forested wetlands in my local area (Louisville, Kentucky), my initial motivations for pursuing this topic were both scientific and personal. From a scientific perspective, these systems offered the opportunity to explore ecological patterns along gradients of stress and resource availability. From a personal perspective, I wanted to explore these locally rare — and often isolated- 
systems, documenting and describing the plant communities of these systems before they vanished permanently.

Finding and gaining access to research sites was an eye-opening experience that helped to shape my research goals and furthered my curiosity about these systems. Knowing that much of southwest Jefferson County had, at one time, been covered by swamp land, I was taken aback by how relatively few patches of wetland forests remained in the area. Furthermore, most of these areas were privately owned, with uncertain prospects for the future. One site (Site 3), was completely landlocked in a sea of concrete, between a shipping yard, train depot, and commercial developments. The boundary between the forest and gravel was abrupt, with semi-trucks touching the tree branches, and frogs jumping out of puddles made by their huge wheels.

With this boundary between the industrial world and nature in mind, my initial research goals for this work were to study changes in woody plant community composition occurring along an edge-to-interior gradient. Studies from upland forest systems showed that changes in resources availability and microclimate occurring at the forest edge affected ecosystem pattern (Chen et al. 1992, Cadenasso and Pickett 2001, Harper et al. 2005) and process (Weathers et al. 2001), but I was not familiar with as much work on edge effects in wetland areas.

After conducting a pilot study, I was somewhat frustrated by my inability to demonstrate what variables were most responsible for controlling important community patterns - such as the presence of invasive species - which did not always show the clear associations with edge habitats I had expected. Adjusting my focal lens to the wetland 
context, I realized I needed to quantify the hydrology of these systems to truly understand the extent of edge effects, as hydrology is of fundamental importance to wetland species distributions. In Chapter II, I show the results of my field research in three forested wetlands, where I link species distributions within and among wetlands to both hydrology and proximity to edge. Special attention is paid to the apparent influence of hydrology on the distribution of an invasive shrub species, Lonicera maackii (Amur honeysuckle).

Following this evidence, I conducted two manipulated experiments testing the effects of simulated flooding on L. maackii at two critical life history stages: seed and seedling. In Chapter 3, the impact of flooding depth and duration, and its potential interaction with light levels, on L. maackii seedling growth and survival is examined in detail. In Chapter 4, I conducted a germination assay of L. maackii seeds subjected to different treatments of simulated flooding and drawdown. 


\section{CHAPTER II}

\section{PATTERNS OF WOODY PLANT COMMUNITIES OVER HYDROLOGIC AND EDGE-TO-INTERIOR GRADIENTS: A STUDY OF THREE URBAN WETLANDS}

\section{$\underline{\text { Introduction }}$}

Current policy in wetland management permits the continued loss of naturally occurring wetlands, a factor that undoubtedly results in a net loss of ecosystem services and wildlife habitat (Faulkner 2004, Mitsch and Gosselink 2007). As a result, remaining forested wetland areas are often highly fragmented. Such fragmentation may have a number of effects that can alter the structure and function of these forest types (Saunders et al. 1991).

Urban forests, generally speaking, are threatened by fragmentation and tend to be smaller than rural counterparts (Medley et al. 1995). Fragmentation increases the perimeter-area ratio of forests, reducing the area of interior forest, increasing the area of forest susceptible to edge effects, and modifying the microclimate of forest boundaries. Edge effects include changes in the forest microclimate — such as light, temperature, soil moisture - and have been demonstrated for various forest types in a number of studies (Matlack 1993, 1994, Chen et al. 1995, Delgado et al. 2007). This perturbation of the abiotic environment has been shown to affect the distribution of individual species, as well as induce changes at the community level (Harper et al. 2005). This is due both to 
species' individual requirements and tolerances, as well as from competitive interactions that may result when the resource environment is altered. Potential differences in herbivore activity along edges as opposed to forest interiors (Jules and Rathcke 1999, Cadenasso and Pickett 2000) may also shape species distributions.

Plant community composition and structure in edge habitats are also affected by species movements through or along edges. For instance, the role of edge habitats facilitating forest colonization by invasive plant species has been the subject of a number of papers (Moran 1984, Brothers and Spingarn 1992, Hutchinson and Vankat 1997, Cadenasso and Pickett 2001, Honnay et al. 2002, With 2002, Pauchard and Alaback 2004, Borgmann and Rodewald 2005, Bartuszevige et al. 2006). This effect is thought to be due to the high light environment of edge habitats, and the proximity of edges to disturbed landscape matrices, which may foster "weedy" species. Edges may also act as filters of plant propagules into a forest, the extent to which is related to the mode of seed dispersal, and the physical structure and composition of edge vegetation (Cadenasso and Pickett 2001).

Most studies of edge effects on plant communities have been conducted in upland systems. In these systems, which are defined by the presence of surface, or near-surface water on an intermittent or continuous basis, site hydrology is the major factor influencing plant distributions. While the surrounding landscape matrix and within-site legacy determine the potential pool of species available to colonize wetland sites, hydrologic conditions are the primary filter determining which species are able to persist. Thus, any potential edge effects due to increased light, propagule pressure, or edaphic factors must be considered in the context of the hydrologic conditions. For instance, 
exotic wetland species from the surrounding landscape matrix may not be able to tolerate wetland flooding, which could offer these systems some resistance to exotic species invasion. Because hydrology is the primary driver of plant species distributions in wetlands, any attempt to measure edge effects must quantify site hydrology and determine if it is affected by the proximity to the forest edge, or if it varies independently of this factor.

With this in mind, the main objectives of this study were as follows:

1) Describe the woody plant community of urban wetlands along edge-to-interior gradients and determine if environmental variables, edge proximity and/or edge orientation is associated with changes in plant community composition.

2) Quantify variation in hydrology between and within research sites and determine its potential association with changes in woody plant composition and structure, with special consideration to the occurrence of invasive woody species.

3) Determine if site hydrology varies with distance to edge.

4) Determine which patterns in community composition (i.e. importance of exotic species, importance of obligate and facultative wetland species and species richness) appeared to be driven primarily by hydrology, and which by distance from the forest edge. 


\section{$\underline{\text { Methods }}$}

\section{Site Descriptions}

All study sites are contained within the boundaries of Jefferson County, Kentucky (total land area of $1000 \mathrm{~km}^{2}$ ) and includes the full extent of the incorporated metropolitan area of Louisville, Kentucky. The northern border of the county is formed by the Ohio River. Within the county borders, the range of elevations observed is 383 to 902 feet above sea level. Jefferson County land use and land cover ranges from highly developed at the urban core, to forest, pasture and cropland towards the county boundary.

The majority of sites selected for this study lies in southwestern Jefferson County in the Pond Creek watershed. This low-lying, $231 \mathrm{~km}^{2}$ watershed has large portions of land that are subject to frequent flooding and ponding, and historically has had the most wetland area in the county (MSD 2006). The low gradient terrain that characterizes this area formed as a result of glacial outwashes from the Quaternary period. In the last century, the creation of ditches (Northern and Southern Ditch) has aided in draining this area for development, which is primarily residential (MSD 2010). However, the shallow elevational gradient in this area still promotes the maintenance of wetland hydrology and vegetation on hydric soils in certain areas. The Louisville Metropolitan Sewer District (MSD) considers the destruction of wetlands in the Pond Creek watershed as a contributor to frequent flooding episodes and water pollution (MSD 2006).

Table 2-1 summarizes the area and soil characteristics of all wetlands selected for inclusion in this study. Study sites were identified using the National Wetlands Inventory (USFWS 2016), county soils data from the Soil Survey Geographic Database (SSURGO; 
Soil Survey Staff, 2009), and high-resolution digital color imagery in ArcGIS. All data sets were used together to locate potential study areas in Jefferson County, but sites had to be identified as meeting hydric criteria according to the SSURGO soils database to be considered further. Potential sites were also disqualified for the following reasons: 1) Forest did not appear to be primarily closed canopy, 2) the forest did not appear to have well-defined north and south-facing edges, 3) forest was $<1$ hectare in size, 3) forest consisted only of thin strips of riparian forest, or 4) landowner information obtained from the Jefferson County Property Evaluation Administrator (PVA) revealed that the property ownership was in a state of flux. Landowner permission was obtained by phone, or mail using addresses on file with the Jefferson County Property Evaluation Administrator (PVA). Access permission was granted by 8 out of $\sim 35$ landowners. Of these 8 , the three with the largest area were chosen.

Soil series determination from each transect location (see Sampling Design) were verified in the field by NRCS personnel. Transects in Site 1 (Max Sawyer), were located on the Melvin soil map unit characterized as frequently flooded, silt loam. Transects in Sites 2 and 3 (Evangel and Trinity), were located on the Zipp soil map unit. NRCS soil descriptions (NRCS 2005) indicate both soil map units meet hydric criteria and have seasonally high water tables present at $0-0.8$ feet of the soil surface. Both soil series are classified as having apparent (i.e. endosaturated), rather than perched (i.e. episaturated) water tables, indicating that zone of soil saturation is continuous from a depth of $2 \mathrm{~m}$ or more to the top of the water table (NRCS 1999).

Site 1 (Max Sawyer) was located in a primarily residential area, adjacent to a major transportation corridor (I-65). Based on my observations, Site 1 (later referred to 
as the "dry" site in this chapter) had undergone the most modification and was the most hydrologically disconnected from the surrounding landscape. Surrounded by residential land use and an interstate, this area has been heavily ditched around the periphery to drain water away from the area (i.e. where transects were located). However, standing water is still present at this site during portions of the growing season, and areas near the water monitoring well routinely had knee-deep water in winter and spring. In some instances, the land immediately outside the forest boundary was lower than that inside the forest; this was most likely a result of grade alterations made in residential plots to drain water away from houses, towards ditches. Although this soil series is characterized as frequently flooded (i.e. inundated by flowing water from stream overflow, or runoff from the adjacent landscape), the extent of ditching through and around the site perimeter appeared to limit flooding events. For instance, drainage ditches running parallel to the forest edge were present at 3 out of the 4 transect locations, effectively intercepting runoff from the adjacent landscape at the forest edge. Additionally, a large ditch runs through the middle of the wetland and drains to nearby Fishpool Creek. This feature is extremely incised, and I never personally observed water levels high enough to overflow onto the adjacent wetland areas. Based on these observations, it appeared that the presence of standing water or near surface water was driven mostly by the influence of the water table and/or precipitation. There was frequent evidence of human disturbance in this site, including numerous waste items, ATV tracks and construction debris.

Site 2 (Evangel) was located adjacent to I-65, but was surrounded on three sides by a fairly large tract of undeveloped open space and pasture. Large ditches ran to the north and south of the site, approximately $100 \mathrm{~m}$ and $200 \mathrm{~m}$ from research areas at the 
forest edge, respectively. In contrast to Site 1, these ditches were further from the forest edge, and the elevation of the land immediately surrounding the forest edge was similar to the elevation within the forest. I later will refer to this wetland as the "intermediate" site.

Site 3 (Trinity, later referred to in the paper as the "wet" site) was the most isolated from other forest and undeveloped spaces, being surrounded by a rail depot, shipping container storage yard, and commercial or industrial space. There was minimal evidence of recent human activity in the wetland and minimal ditching at the forest edge (shallow concrete ditches were present on the north and west sides). This was the only Site where I ever observed any visible sheet flow of water; this was observed near the sampling well in the forest interior.

\section{Sampling Design}

Before establishing sampling transects, aerial imagery of each site was examined, and areas with well-defined north- and south-facing edges were identified. In the field, segments of edge on the north and south forest with continuous canopy cover were identified (i.e. no large canopy gaps along the edge, or within $\sim 100 \mathrm{~m}$ of the edge). The boundaries of this candidate area were flagged, and a random number table was used to choose a point along the edge to be the starting point of the edge-to-interior transect. Two edge locations were flagged on both north- and south-facing edges at each site. Care was given to avoid locating transects within $100 \mathrm{~m}$ of one another on the same edge, or within 60 meters of an adjacent forest edge. Aerial images of all research sites are included in Appendix Figures 1, 2 and 3 with the location of transects. 
Fig. 2-1 shows the transect design and components. The edge boundary was marked at each of the four flagged edge points at each site. This was done by moving from the surrounding landscape matrix towards the forest edge until the canopy cover transitioned to approximately $80 \%$ cover. A flag was placed at this point, and at 1, 5, 10, 30 and $60 \mathrm{~m}$ from this point towards the forest interior, in a straight line, thus forming the edge-to-interior transect.

At each of the five marked distances along the edge-to-interior transect, a second set of $12 \mathrm{~m}$ long transects running parallel to each other were delineated. These were referred to as parallel transects. During environmental and plant sampling procedures (see following sections), four temporary 2 × 2 m quadrats delineated by PVC frames were placed $1 \mathrm{~m}$ apart from each other, centered along the midpoint of parallel transects. A second set of $12 \times 12 \mathrm{~m}$ plots for measuring adult trees was centered over the $6 \mathrm{~m}$ and 60 m midpoints of the edge-to-interior transect.

To summarize, each site contained four edge-to-interior transects (two on the north- and two on the south-facing sides) running from the forest edge to $60 \mathrm{~m}$ towards the forest interior. Parallel transects $(12 \times 2 \mathrm{~m})$ were established at 1, 5, 10, 30 and $60 \mathrm{~m}$ along each edge-to-interior transect. Four $2 \times 2 \mathrm{~m}$ quadrats were nested within each 12 x $2 \mathrm{~m}$ parallel transect.

\section{Data Collection Dates}

All woody plant (see Plant Data Collection, below), ground cover and elevation data (see Environmental Data Collection, below) were collected during the summer of 
2010. Dates of data collection in 2010 for each site were: August 17 to September 9 at Site 1 , June 29 to July 19 at Site 2, and July 23 to August 13 at Site 3.

Hydrologic data-including surface water elevations along each edge-to-interior transect and groundwater level data—was collected the following summer of 2011. Together with ground surface elevations taken during 2010, this data was used to estimate the average number of days each transect was flooded (see Environmental Data Collection). Although this data was not collected during the same time period as plant data, I felt it was valid to apply this data to characterize the flooding of each transect and relate to woody vegetation community data. In systems with highly dynamic microtopography, this could be problematic because surface elevations could vary greatly year to year. There were two reason I felt this was not an issue in these systems. For one, personal observations made for three consecutive seasons indicated that that there was minimal disturbance of microtopography between years. This was assessed by noting that large soil deposits on top of leaf litter were rare, and that observed water in all but one perpendicular transect was always ponded, stagnant water, with no observable flow. At Site 2, transect "S2" was the only exception to this, but noticeable flow was minimal and occasional. If microtopography were highly dynamic, I would have expected to observe frequent deposits of soil. Based on my familiarity with these sites, I felt it was reasonable to estimate the number of days each transect was flooded based on 2010 elevation data in combination with ground and surface water data obtained the following summer. Furthermore, since I was dealing with woody, perennial species, whose distributions are reflective of long-term environmental trends, I felt it was 
reasonable to view flooding trends in 2011 as a relative measure of overall hydrologic differences between transects and sites, and relate these to plant data from 2010.

\section{Environmental Data Collection}

In each sampling quadrat, the ground cover of several variables was estimated. These variables were: 1) percent bare soil, 2) percent leaf litter 3) percent coarse woody debris (widths $>10 \mathrm{~cm}, 4$ ) percent herbaceous cover. While bare soil and litter were considered mutually exclusive (additive) cover types, others were not. For instance, herbaceous cover or coarse woody debris could occupy the same two-dimensional space as leaf litter or bare soil. Thus, total ground cover could be greater than $100 \%$. In some instances, leaf litter was covered by a relatively thin layer of sediment ( 1-4 mm) due to recent flooding events, but leaf litter was still clearly distinguishable underneath this layer; this was counted as leaf litter cover. Bare soil was primarily evident in areas of relatively high relief (i.e. mounds, sides of ditched areas) where leaf litter did not accumulate. Coarse woody debris was defined as woody material having an average diameter of $10 \mathrm{~cm}$ or greater. The percent cover of each ground cover type was recorded as falling in one of the following classes: $<5 \%, 6-25 \%, 26-50 \%, 51-75 \%, 76-95 \%$ or $95+\%$. The canopy closure of each transect (a proxy for light availability) was estimated using a spherical densiometer held $\sim 1 \mathrm{~m}$ from the ground surface in each transect (Robert E. Lemmon, Forest Densiometers, Bartlesville, OK).

Hydrologic conditions in each parallel transect were quantified by combining data from three datasets: 1) detailed surveys of microtopography in each parallel transect during 2010,2 ) readings of water levels in wells made throughout the growing season in 
2011, and 3) surface water levels recorded in each transect on select dates in 2011. The following paragraphs detail how this data was collected and combined to estimate hydrologic conditions.

During the summer of 2010 (when plant data was collected), detailed surveys of transect microtopography were conducted. A permanent elevation benchmark (i.e. a nail in a tree, or piece of rebar in a high elevation area) was established at each edge-tointerior transect (Fig.2-2). Using a surveyor's level and stadia rod (CST/Berger SAL Level), an assistant and I recorded the elevation of 10 points in each $2 \times 2 \mathrm{~m}$ quadrat. These elevations were made relative to the established benchmark at each edge-tointerior transect. Elevation sampling points within quadrats were randomly chosen along lengths of PVC placed in each half of the quadrat.

In spring of 2011, a shallow ground water well $1 \mathrm{~m}$ deep was installed at each of the three wetland sites (Appendix Fig. 4). Each was placed in an interior location (> 100 $\mathrm{m}$ from forest edges) where flooded conditions were evident in the immediate vicinity. However, to avoid surface water entering the wells, wells were installed in locally high sites that did not appear to be frequently flooded above the soil surface. Following established protocols for installing groundwater monitoring wells (Sprecher 2008), slotted well casings (with an unslotted riser within $35 \mathrm{~cm}$ of the soil surface) extended 1 $\mathrm{m}$ below the soil surface. These were surrounded with packed, coarse sand $(\sim 5 \mathrm{~cm}$ below the well bottom and to the sides). The sand extended $\sim 5-10 \mathrm{~cm}$ above the slotted portion of the well. Bentonite clay was then packed around the riser to the soil surface, and a mixture of field soil and bentonite was mounded around the base of the well above the ground surface. Above the mounded soil, wells were vented (i.e. a hole was drilled) to 
equalize pressure between the well environment and open air pressure. The location of the wells in areas of slightly higher elevation than adjacent flooded areas, and the bentonite clay seal were intended to prevent surface water entering the wells directly, so that groundwater levels could be accurately measured. PVC housing constructed for a water level data logger was mounted on top of each well casing, and equipped with a waterproof cap. The total length of each well with the housing was $1.75 \mathrm{~m}(0.75 \mathrm{~m}$ extending above the soil surface). Each well was equipped with a Global Water WL15 water level data logger (Global Water, College Station, Texas). This device uses a pressure transducer to measure the amount of water above the sensor. Following manufacturer procedures, each device was calibrated to accurately record water levels. Sensors were placed at the well bottom. Water levels in each well were recorded continuously on an hourly basis from 5/2/2011 to 8/26/2011, a total of 123 days.

Monitoring points for measuring surface water depth were established at approximately 10, 30 and 60 meters along each edge-to-interior transect in May 2011. These were lengths of PVC pipe approximately $0.75 \mathrm{~m}$ long that were pounded into the soil (Fig. 2-2). The elevation of the top of these monitoring points was recorded relative to the permanent site benchmark established the previous summer. On 3 to 4 dates, when surface water was present at each site, the distance between the top of the monitoring point and the water surface was measured. These values were ultimately used to reference the elevation of the of the water surface to the site elevation datum, and determine the difference between the daily average water table elevation and surface water levels (see below). This enabled the prediction of daily surface water levels in each parallel transect. 
A final elevation survey at each site was conducted to measure the elevation of permanent elevation benchmarks relative to one another, thereby registering them to the same datum and one of the four permanent elevation benchmarks at each site was used as a reference point for the whole site. The elevation of the top of the water monitoring well was also recorded during this survey. To summarize, for each site the resulting dataset had all of the following information relativized to the respective site's datum: 1) ground surface elevations in quadrats where plants were collected in 2010,2) the elevations of surface water monitoring points, and 3) elevation of the top of the groundwater monitoring well.

Fig. 2-2 provides a visual aid for interpreting the following calculations. Daily mean height of water in each well was calculated. The average water table surface elevation on each day $\left(\boldsymbol{E}_{\boldsymbol{w} t}\right)$ was calculated by subtracting $1.75 \mathrm{~m}$ (total well length) from the top of well elevation $\left(\boldsymbol{E}_{\text {well }}\right)$ and adding the daily mean height of the water table above the sensor $\boldsymbol{h}_{\boldsymbol{w}}$ (Eq. 1). For each day water surface elevations were measured (3-4 days at each point) the elevation of the water surface $\left(\boldsymbol{E}_{\boldsymbol{w}}\right)$ at each monitoring point was calculated by subtracting the distance measured from the top of the water monitoring point to the water surface $\left(\boldsymbol{D}_{\boldsymbol{w}}\right)$ from the elevation of the top of the monitoring point $\left(\boldsymbol{E}_{\boldsymbol{w m}}\right.$, Eq. 2). Finally, the height difference between the water surface (in each transect) and the water table $(\Delta w t)$ surface was calculated for each day water surface measurements were made. This was done by subtracting the elevation of the water table $\left(\mathbf{E}_{\boldsymbol{w} t}\right)$ from the water surface elevation $\left(\mathbf{E}_{\boldsymbol{w}}\right)$. This calculation is given in Eq. 3.

\section{Eq. 1}




$$
\mathrm{E}_{w t}=E_{w m p}-1.75+h_{w t}
$$

Eq. 2

$$
\mathrm{E}_{w s}=E_{w e l l}-D_{w s}
$$

Eq. 3

$$
\Delta \mathrm{wt}=E_{w s}-E_{w t}
$$

Average values of $\Delta \mathbf{w t}$ were calculated for each water monitoring point, and this number was added to daily values of mean water table elevations to estimate the average elevation of the water table at each monitoring point, for each day of the monitoring period. Since the water surface was not always level (e.g. because of ditching) these values could be very different along an edge-to-interior transect. Water table elevations generated from $10 \mathrm{~m}$ monitoring points were applied to parallel transects at 1, 5 and 10 m. Water table elevations from $30 \mathrm{~m}$ and $60 \mathrm{~m}$ monitoring points were applied to parallel transects at their respective distances.

Using the ground surface elevations measured in 2010, I used predicted values of the water table elevation in each parallel transect to estimate how many days each ground surface elevation data point was flooded in 2011 (40 points/transect). For every day of the monitoring period, a point was considered "flooded" if it was equal to, or lower than, the predicted water level. Thus, every elevation point, in every quadrat, had a corresponding value for "days flooded". These values were averaged over a quadrat, and quadrats were averaged over the parallel transect. The resulting value, describing the wetness of each parallel transect, is referred to as "days flooded" or "number of flooded 
days" for the rest of the chapter. Because this estimate incorporated elevation data, it is reflective of how microtopography impacts the overall "wetness" of a local area.

During June of 2011, leaf area index (LAI) data was recorded. A LAI-2000 Plant Canopy Analyzer was used to measure LAI (LI-COR, Lincoln, Nebraska). LAI is a unitless ( $\mathrm{m}^{2}$ leaf $/ \mathrm{m}^{2}$ ground surface) measure of foliage quantity, and commonly used as a measure of productivity. This was of interest directly, and because it should be inversely related to light availability at the forest floor. Standard protocols for measuring LAI were followed as per the manufacturer's recommendations (LI-COR 1992). LAI was measured in 4 locations per parallel transect, in the approximate quadrat locations from the previous season of field work. Measurements were made away from tree trunks, as the sensor registers any light blocking object as leaf area. I also used an equipped filter to block my own outline from the sensor, and made measurements of LAI approximately $0.5 \mathrm{~m}$ from the ground surface. Sensor data was downloaded and the manufacturer software was used to compute values of LAI.

\section{Plant Data Collection}

Plants were sampled in area units described in Sampling Design. Adult trees were defined as those with a diameter at breast height $(\mathrm{dbh})$ greater than $2.5 \mathrm{~cm}$. The species identity and dbh of all living trees in $12 \times 12 \mathrm{~m}$ edge and interior plots was recorded (4 edge and 4 interior plots at each site). All other plant data was collected within 2 x $2 \mathrm{~m}$ quadrats in each parallel transect. Woody vines falling in each quadrat were identified, and recorded as $\%$ cover in the following ranges: $<5 \%, 6-25 \%, 26-50 \%, 51-75 \%, 76-$ $95 \%$ or $95+\%$. Vine cover on the ground and in the canopy above a quadrat was tallied 
separately. Stem counts of saplings species $(<2.5 \mathrm{~cm}$ dbh and $>30 \mathrm{~cm}$ tall $)$ and shrub species in each quadrat were also recorded. For tree seedlings, a distinction was made between" recent germinants" and "established seedlings". Recent germinants generally only had 1-2 pairs of leaves and/or cotyledons. Established seedlings had some woody tissue formation and/or more than 2 pairs of leaves.

For shrubs, stem counts for individual plants were tallied when possible, but this was difficult for clonally growing species such as Cornus foemina. Because the growth habit of shrubs varied, I tried to sample stem counts in a consistent manner. First, individual shrubs (or a definable clump of clonally growing shrubs) were placed into a height category based on the average height of plant stems. These categories were $<0.25$ $\mathrm{m}, 0.25-0.5 \mathrm{~m}, 0.5-1.0 \mathrm{~m}, 1.0-2.0 \mathrm{~m}$, and over $2 \mathrm{~m}(2+\mathrm{m})$. The number of stems originating within the first $0.3 \mathrm{~m}$ of the ground was recorded as the stem number of the individual. Finally seedlings ( $<0.3 \mathrm{~m}$ tall) were counted by species.

The elevation of all Lonicera maackii shrubs was also recorded. Using data from the ground elevation survey, each shrub was assigned an elevation rank, based on its relative elevation within a parallel transect. Ranks were calculated using the "PERRANK" function in MS Excel, which returns a ranking of a value (range: 0-1) as a percentage of a range of values. For individual plants, this function was used to calculate the elevation rank of all L. maackii shrubs, based on the range of sampled ground elevation values in a parallel transect (80 sampled elevation points). Therefore shrubs near the highest sampled ground elevation point would rank close to 1 , and those near the lowest points would rank close to 0 . In a few instances, the elevation of plants fell outside the range of sampled elevation points. In these cases, the plant was assigned a 
rank of " 0 " if it was lower than the lowest sampled elevation point and " 1 " if it was higher than the highest sampled elevation point.

The intention of obtaining this data was to examine the relationship between rank elevations of L. maackii and the number of flooded days in parallel transects where they occurred. If flooding constrained the range of suitable habitat for L. maackii, I expected the rank elevation of shrubs to increase with the number of days flooded.

\section{Data Treatments}

Stem counts for saplings, seedlings and shrubs per quadrat were totaled over each parallel transect by adding quadrat level data. Stem counts for each species and vegetation layer (i.e. seedlings, saplings, etc.) were converted to density in $\mathrm{m}^{2} \mathrm{ha}^{-1}$. For vines, values of total percent cover were determined by adding together the percent cover of vines on the ground and in the canopy. Thus, it was possible for vines to have greater than $100 \%$ cover. For each vegetation layer, the frequency, relative frequency, relative density (relative cover for vines) and importance value (IV) were calculated. For a species, $X$, these measures were calculated as follows for each vegetation layer, in each parallel transect.

Density $=\frac{\text { total \# of stems of species } X \text { in parallel transect }}{16 \mathrm{~m}^{2}} \times 10,000 \frac{\mathrm{m}^{2}}{\mathrm{ha}}=$ stems $/$ ha

$$
\text { Frequency }=\frac{\text { number of quadrats containing species } X}{4}
$$




$$
\begin{gathered}
\text { Relative Frequency }=\frac{\text { frequency of species } X}{\text { sum of all species frequencies }} \\
\text { Relative Density (or \% Cover) }=\frac{\text { density (or \% cover)of species } X}{\text { sum of all species densities (or total \% cover) }} \\
\qquad \text { IV }=\frac{\text { Relative Frequency }+ \text { Relative Density }}{2} \times 100
\end{gathered}
$$

Adult basal area was calculated by summing the total cross sectional area (in $\mathrm{m}^{2}$ ) of species by plot and expressing it in terms of $\mathrm{m}^{2} / \mathrm{ha}$.

$$
\text { Basal Area }=\frac{\text { total cross sectional area of species } X\left(\mathrm{~m}^{2}\right)}{144\left(\mathrm{~m}^{2}\right)} \times 10,000 \frac{\mathrm{m}^{2}}{\mathrm{ha}}=\frac{\mathrm{m}^{2}}{\mathrm{ha}}
$$

Relative basal area and IV values were then calculated as above, substituting basal area for "density".

For ordination (see Statistical Analysis), "Exotic Vine IV" and "Exotic Shrub IV" were calculated by summing the total importance values of species meeting those criteria within each parallel transect. "Exotic" was defined as having provenance outside of North America.

Species richness was calculated by vegetation layer as the total number of species. Shannon diversity (Magurran 2013) was calculated according to the following equation, where $p$ is the relative density or relative cover of a species.

$$
\mathrm{H}=\sum_{i=1}^{s} p_{i} \ln p_{i}
$$


Environmental variables were averaged at the parallel transect level for analyses listed below.

\section{Statistical Analyses}

For certain variables of interest (species richness of individual plant strata and abundance of species of interest), I performed multiple regression using a mixed linear model (PROC MIXED in SAS 9.4) to test if these response variables varied with fixed effects of site, edge orientation, or distance from edge, and included all 2 and 3-way interactions between these variables. Parallel transects represented individual samples. The ID of an edge-to-interior transect was included as a random blocking effect within site and side (i.e. north vs. south). For count data (density or number of species) I first tried modeling the data using the Poisson distribution (recommended for count data) and the link=logit method. In all instances, data were over-dispersed as indicated by model output indicating $X^{2}$ values divided by degrees of freedom were substantially greater than one. In this case the negative binomial distribution was used, which is recommended for over-dispersed data, and the logit link. Failure of the model to fit random effects indicated over-fitting of the model and the random blocking effect was removed from the model. The model was then rerun with only fixed effects in PROC MIXED or PROC GENMOD. When comparing the number of days flooded between sites, number of days flooded was treated as a continuous variable. Model residuals were examined for normality and homoscedasticity. Percent cover data were modeled using the arcsine transform where:

$$
\mathrm{Y}(\text { Transformed })=\operatorname{arcsine}\left(\mathrm{y}^{-2}\right)
$$


Non-metric multidimensional scaling (NMS) is an ordination method often used to find patterns in plant community data. I used the PC-ORD software following guidelines recommended in McCune et al. (2002) to run this procedure. The species matrix was composed of importance values of all species, for each parallel transect separated by vegetation layer. For instance, Fraxinus sp. seedlings and saplings were entered as separate "species". Adults were not included because they were sampled at a different scale. Species occurring in fewer than three transects were removed from the matrix ( $\sim 5 \%$ of transects), as recommended. The outlier analysis function in PC-ORD was used to find transects that were outliers ( $>2$ standard deviations from the mean) and these were removed from the analysis due to concerns over model stability. Three transects from Site 3 were removed from the analysis because of this. I used PC-ORD autopilot mode ("slow and thorough" method) to run the ordination and checked that model stress was within an acceptable range, as recommended in (McCune et al. 2002).

Secondary matrices summarizing environmental data variables and biotic variables were created in Excel and imported into PC-ORD. These data were used for creating biplots depicting relationships between these variables and ordination axes. Variables included in the environmental matrix were: days flooded, distance from edge, percent herb cover, percent coarse woody debris, LAI, and percent canopy closure. Percent bare soil was not included because it was highly correlated with percent leaf litter and contributed essentially no unique information. The biotic matrix contained summary variables about exotic species, wetland indicator status and the total density or cover of plants from individual vegetation layers (i.e. saplings, tree seedlings, shrubs, vines). Wetland Indicator Status (WIS) information was obtained from PLANTS Database 
(USDA 2016). I used regional statuses for the Eastern Piedmont Region. These designations indicate the association of particular species with wetland habitats. The WIS for species from this study are shown in Appendix Table 16. The total IV of species with facultative wetland (FACW) or obligate wetland (OBL) status was calculated for each vegetation layer and included in the matrix. Other biotic variables were: exotic shrub IV, exotic vine IV, total seedling density, total sapling density, total vine cover, and total shrub stem density.

\section{$\underline{\text { Results }}$}

\section{Environmental Variables}

\section{Site-Level Environment}

The three sites differed in hydrology, as shown by differences in the number of days flooded $\left(X^{2}(2)=28.24, \mathrm{p}<0.0001\right.$; Table $)$ and visual comparison of site hydrographs (Fig. 2-3). Site 1 transects had the fewest number of flooded days (i.e. days where surface water level was $\geq$ ground level, mean of $3.9 \pm 1.9$ days ) with 5 out of the 15 transects experiencing an average of zero days of flooding. At Site 2, days flooded ranged from $0.4 \pm 0.2$ to $71.9 \pm 4.9$ days flooded, (mean of $19.9 \pm 3.7$ ). Site 3 transects experienced the highest number of flooded days, (range: 0 to $84.5 \pm 0.4$; mean of $39.4 \pm 7.6$ days). Tukey's pairwise comparisons confirmed a significant difference in days flooded between Site 1 and 3 (Tukey's adjusted p < 0.0001) and Sites 2 and 3 (Tukey’s adjusted p $<0.0001$ for both comparisons, Table 2-2). Based on these findings, Sites 1, 2 and 3 are hereafter referred to as the "dry", "intermediate" and "wet" sites, respectively. The mean number of days flooded for all parallel transects, edge-to-interior transects and sites is given in Table 2-2. 
All values for mean days flooded, other environmental variables (averaged over edge-to-interior transects) and sites are given in Table 2-3. Mean LAI was highest for the dry site (4.42 \pm 0.12$)$, with values of $2.76 \pm 0.12$ and $3.80 \pm 3.0$ for the intermediate and wet sites, respectively. Percent canopy closure was similar among sites, and ranged from $89.0 \pm 1.5 \%$ at the wet site to $91.1 \pm 1.6$ at the intermediate site. Herb cover varied greatly between sites, being lowest in the dry site $(13.4 \pm 3.5 \%)$ and similar in the other sites $(60.3 \pm 17.1 \%$ and $56.4 \pm 2.5 \%$, for the intermediate and wet site, respectively).

Environmental data at the transect scale is listed in Appendix Table 2.

\section{Associations among Environmental Variables}

Pearson correlations between environmental variables at the landscape scale (calculated by including transects from all sites) are given in Table 2-4. Percent leaf litter and percent bare soil were essentially redundant variables that were highly correlated $(\mathrm{r}=$ $-0.98, \mathrm{p}<0.0001$. Days flooded was also positively correlated with $\%$ herbaceous cover $(\mathrm{r}=0.31, \mathrm{p}=0.023), \%$ bare soil $(\mathrm{r}=0.41, \mathrm{p}=0.008)$ and negatively correlated with $\%$ canopy closure $(\mathrm{r}=-0.3662, \mathrm{p}=0.006)$. Herb cover and LAI were negatively correlated $(\mathrm{r}=-0.63, \mathrm{p}<0.0001)$

At this scale of examination, considering transects from all sites, no environmental variables correlated with distance from edge. However, because flooding and distance from forest edge were both expected to be important factors affecting plant communities, it was necessary to know if these variables were still independent of one another at the site level. At the landscape scale, when transects from all sites were included, these variables were not shown to be related $(r=0.1160, p=0.4)$. At the 
intermediate site, there was a marginally significant, positive correlation between days flooded and distance from edge $(\mathrm{p}=0.07, \mathrm{r}=0.41)$, indicating a probable lack of independence between these factors at this location. At the other two sites, distance from edge was not correlated days flooded $(\mathrm{r}=0.19, \mathrm{p}=0.49$ at the dry site; $\mathrm{r}=0.01, \mathrm{p}=0.96$ at the wet site). Therefore, based on these three forested wetlands, the assumption that distance from edge will necessarily be correlated with hydroperiod cannot be made.

\section{Woody Plant Communities}

\section{Adult Trees}

The total basal area of adult trees ranged from $32.5 \pm 4.1$ to $47.1 \mathrm{~m}^{2} \mathrm{ha}^{-1}$ in the wettest and driest site, respectively (Table 2-5). Acer rubrum (red maple, FAC) adults had the highest IV and basal area at all three sites (Table 2-5). At the wet and intermediate site, Fraxinus pennsylvanica (green ash, FACW) and Celtis laevigata (sugarberry, FACW) were in the top three highest importance values. At the driest site $F$. pennsylvanica and Liquidambar styraciflua (FAC) were the second and third most important species, respectively.

Adult tree species richness was highest at the dry site (15 species, $5.8 \pm 1.0$ species/144 $\mathrm{m}^{2}$ plot, Table 2-6), but there was no significant difference among sites ( $\mathrm{p}$ > 0.8). Total species richness of adult trees at the intermediate and wet sites was was 10 and 12 species ( $4.8 \pm 0.4$ and $5.3 \pm 0.6$ species $/ 144 \mathrm{~m}^{2}$ plot, Table $2-6$ ), respectively. Six species of trees occurred only at the dry site; of these 6 species, 5 were found in the edge (first $10 \mathrm{~m}$ ) only (L. styraciflua, Liriodendron tulipifera, Ulmus rubra, Populus deltoides and Nyssa sylvatica; Appendix Table 3). Of these five species, all except N. sylvatica 
were facultative upland species. Considering all sites, mean adult richness was higher at the edges $\left(6.58 \pm 0.65\right.$ species $/ 144 \mathrm{~m}^{2}$ plot $)$ than the interior $\left(3.92 \pm 0.08\right.$ species $/ 144 \mathrm{~m}^{2}$ plot) and this difference was significant $\left(X^{2}(1)=7.8, p=0.005\right.$, Appendix Table 4). Across sites, mean adult diversity $(\mathrm{H})$ was $1.32 \pm 0.05$ and $1.00 \pm 0.09$ in edge and interior plots, respectively (Appendix Table 5).

\section{Saplings}

The total density of saplings ranged from $12,094 \pm 3273$ to $4594 \pm 4593$ stems ha $^{-1}$, at the wet and dry sites, respectively (Table 2-7), and decreased with distance from the edge (Appendix Figure 5). Mean frequencies, densities and importance values of sapling species at all distances from the edge, at each site, are presented in Appendix Table 7.

F. pennsylvanica saplings had the highest mean density of any species at all three sites, and the highest importance values at the wet and dry site (Table 2-7). At the wet site, it had the highest density of any species at all distances from the edge, with

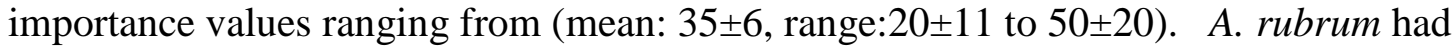
the second highest mean density and IV at the wet site. At the intermediate site, $C$. laevigata and $F$. pennsylvanica had the highest two importance values and/or densities at all distances. This pattern was similar at the dry site, with those two species maintaining high densities and/or importance values at all distances. Asimina triloba (pawpaw, FAC) was unique to the dry site and had higher densities than other species at 30 and $60 \mathrm{~m}$ from the forest edge.

Species richness of saplings declined with distance from the forest edge $\left(F_{1,42}=\right.$ $6.8, \mathrm{p}=0.013$, Appendix Tables 5 and 6). Seven species (plus one unidentified species) 
were found exclusively in transects from 1-10 meters, while only two species were found exclusively in the 30 or $60 \mathrm{~m}$ transects. Species found exclusively at the edge included FACU, FAC, FACW and OBL species, and all were fairly rare within sampled areas. These species included L. tulipifera saplings (FACU) and Nyssa sylvatica (FAC), which were only found at the wet site, but limited to the edge $(5$ and $10 \mathrm{~m})$. Four of these seven species are considered shade intolerant (L. tulipifera, Salix nigra, Platanus occidentalis and Sassafras albidum), while N. sylvatica is considered shade tolerant. The other two species (Prunus sp. and Crategus sp.) were only identified at the genus level.

\section{Seedlings}

Total seedling density ranged from $2906 \pm 644$ to $7156 \pm 1855$ stems ha $^{-1}$ for the dry and intermediate sites, respectively (Table 2-8). F. pennsylvanica had the highest importance value and density of seedlings at all sites. Celtis laevigata, which was the second most important and abundant species at the intermediate and dry site, was very uncommon at the wet site, despite having basal area of adults comparable to those in the other sites. According to Burns and Honkala (1990), this species is intolerant of flooding in the seedling stage and this may explain its low abundance at this site. No relationships between species richness and site, edge orientation or distance from edge were found.

Seedling density appeared to differ in north vs. south facing plots. This was tested for significance. Mixed-model regression indicated a significant interaction between edge orientation and distance from edge on seedling density $\left(\mathrm{F}_{1,41}=6.26, \mathrm{p}=\right.$ 0.016, Appendix Table 8), with no significant effects of site. Since seedling density did not appear to have a clear relationship with distance from edge (Appendix Fig. 6), the 
significance of this interaction is most likely due to seedling density being generally higher in south sides at all distances except $60 \mathrm{~m}$, where they were approximately equal. As seen in figure (Fig. 2-4), F. pennsylvanica was a major contributor to high seedling densities in south-facing transects. At all sites, $F$. pennsylvanica maintained high, if not the highest, importance values in the seedling layer at all distances from the edge (Appendix Table 9). C. laevigata was generally the next most important species at the intermediate and dry site, at all distances; an exception was the intermediate site at $30 \mathrm{~m}$. Quercus palustris (pin oak, FACW) was another relatively important seedling species that reached its highest densities at 30 and $60 \mathrm{~m}$, but appeared to have a stable distribution throughout the edge zone (1-10 m) as well.

Two species that were present as adult trees at the intermediate site, but did not appear as seedlings (or saplings) were Populus deltoides (cottonwood, FAC) and Platanus occidentalis (American sycamore, FACW).

\section{Shrubs}

Shrub species richness differed significantly by site $\left(F_{2,9}=10.3, p=0.005\right.$, Appendix Table 10) and the dry site had significantly higher species richness than the two other sites (Tukey adjusted $\mathrm{p}=0.005$ for dry site vs. intermediate site, Tukey adjusted $\mathrm{p}=0.03$ for wet vs. dry site). Thirteen shrub species were present at the dry site (Table 2-9), with four species found only at that site. These species were: L. benzoin, Euonymus alatus (burning bush, an exotic species, wetland indicator status undetermined), Euonymus americanus (bursting-heart, FAC), and a Prunus sp. In contrast, only three shrub species were present at the intermediate site: Lonicera maackii 
(Amur honeysuckle, an invasive exotic), Rubus sp. and Cornus foemina (stiff dogwood, a FACW native). Eight species of shrubs were found at the wet site, and two of thoseCephalanthus occidentalis (buttonbush, a native wetland OBL) and Aralia spinosa (devil's walking stick, FAC) —-were unique to that site.

The shrub species with the highest importance value differed for all three sites (Table 2-9). The most important shrub species at each site were: Lindera benzoin (dry site, IV $=41 \pm 5.3$ ), Lonicera maackii (intermediate site, IV = 43.1 \pm 9.5 ) and Cornus foemina (wet site, IV = 40.1 \pm 8.7 ). L. benzoin (spicebush) was found exclusively at the dry site, but the other two species were present at all sites. The stem density of these three shrub species at each site is compared in Fig. 2-5, along with Rubus spp., which also occurred at all sites.

At $1 \mathrm{~m}$ from the forest edge, Rubus sp. had the highest stem density and/or importance value across sites, and tended to decline in importance with distance from the forest edge (Appendix Table 11). In the wet site, C. foemina was the most important species at all distances from the forest edge. In the dry site, L. benzoin was dominant from 5 to $60 \mathrm{~m}$ from the edge, with L. maackii and Rubus sp. maintaining lower, but relatively stable, importance values in the same areas. At the intermediate site, $L$. maackii appeared $5 \mathrm{~m}$ from the forest edge, then maintained high importance values at 5, 10 and $30 \mathrm{~m}$ from the forest edge (IV values of $75 \pm 15,92 \pm 8$ and $44 \pm 18$, respectively), then substantially decreased in density at $60 \mathrm{~m}$, leaving $C$. foemina as the dominant shrub. Total shrub stem density did not appear to have any relationship to distance from edge (Appendix Fig. 7). Densities of L. maackii clearly declined with distance from edge at the intermediate site, but this trend was not seen at the other sites (Appendix Fig. 8). 
As discussed previously, the number of days flooded increased with distance from the edge at the intermediate site only. In view of this, it seems likely that hydrology, not proximity to the forest edge, was a more likely driver of this pattern at the intermediate site.

Density of L. maackii differed significantly between sites, with both the dry and intermediate sites having greater stem densities than the wet site (Tukey adjusted $p=0.01$ for both comparisons, Appendix Table 12). The size class structure of L. maackii stems was similar among sites, though the dry site had a greater density of stems in the largest height category (>2 m tall), but this was not tested for significance (Fig. 2-6). Because $L$. maackii has been negatively correlated with native shrub densities in other studies, I examined correlation values between the density of this species and the three other dominant shrubs. None of these correlations was significant $(\mathrm{p}>0.3)$.

\section{Vines}

The vine community at the wet and intermediate sites was dominated by Toxicodendron radicans (poison ivy, FAC), which had importance values of $49 \pm 8$ and $58 \pm 6$ at each site, respectively (Table 2-10). At the dry site, Lonicera japonica (Japanese honeysuckle, an exotic, invasive species) was the most important species (IV=38 \pm 4 ). Total vine cover generally declined towards the forest interior (Appendix Fig. 9). Along edge-to-interior transects in the intermediate and dry site, $T$. radicans retained the highest importance values and percent cover at all distances from the forest edge (Appendix Table 14). At the dry site, L. japonica had the highest importance values and percent 
cover at all distances except $30 \mathrm{~m}$, where Euonymus fortunei (wintercreeper, an exotic invasive species) was more abundant. No vine species were unique to any one site.

Lonicera japonica had significantly different cover between sites. $\left(\mathrm{F}_{2,12.5}=7, \mathrm{p}=\right.$ 0.009, Appendix Table 12) with coverage in the dry site being higher the two other sites. It also showed a pattern of decreasing cover with distance from the forest edge at all three sites (Fig. 2-7) and this trend was significant $\left(\mathrm{F}_{1,42}=7, \mathrm{p}=0.01\right.$, Appendix Table 12).

\section{NMS Ordinations: Community Patterns and Environmental Correlates}

The initial run of the NMS used mean woody species IVs calculated from all parallel transects at all sites. The solution resulted in three axes explaining $72.2 \%$ of the variation in the plant community composition with a final stress of 17.64. The environmental biplot in Fig. 2-8 shows the position of transects and species by strata (vines, shrubs, tree seedling, and saplings) based on their association with the resulting NMS axes, as well as vectors indicating environmental variables also associated with these axes. Fig. 2-9 shows transects and species by strata plotted identically as in Fig. 28 , but displayed with vectors indicating axis associations with biotic variables such as wetland indicator status, exotic status and total abundance by stratum (i.e. shrub stem density). Referring to both figures, it is possible to make indirect associations between species distributions, environmental variables and community patterns. Table 2-11 summarizes the predominant species, environmental variables, and biotic variables that were most strongly associated with Axis 1 and 3 .

Plotting transects in relationship to Axis 1 and 3 (Fig. 2-8) revealed clear compositional differences between Site 1 (dry site) and the two other sites, based on their 
position in ordination space. Axis 1 explained $34.5 \%$ of the variation in the species matrix and had a positive correlation with the number of days flooded $\left(r^{2}=0.38\right)$ and was the primary dimension that separated site 1 (dry site) from the 2 others (Fig. 2-8). The total IV of exotic vines and total shrub density were negatively associated with Axis 1 $\left(r^{2}=0.44\right.$ and $r^{2}=0.19$, respectively), while the IVs of FACW/OBL shrubs and percent herbaceous cover were positively associated with this axis $\left(r^{2}=0.40\right.$ and $r^{2}=0.34$, respectively; Fig. 2-9). The two species most strongly associated with Axis 1 were both shrubs; Cornus foemina (FACW) and Lindera benzoin (FAC) displayed positive $\left(\mathrm{r}^{2}=0.34\right)$ and negative $\left(\mathrm{r}^{2}=0.59\right)$ associations with Axis 1, respectively. The negative association between Axis 1 and shrub density was probably due to the influence of Lindera benzoin, which achieved high densities at the "dry" site (Site 1). Axis 3 was positively correlated with Celtis laevigata seedlings $\left(\mathrm{r}^{2}=0.20\right)$, distance from forest edge $\left(r^{2}=0.20\right)$, and total seedling density $\left(r^{2}=0.20\right.$; Fig. $\left.2-8\right)$.

Axis 2 was positively associated with percent vine cover $\left(r^{2}=0.21\right)$ and the IV of exotic shrubs $\left(r^{2}=0.45\right.$; Fig. $\left.2-10\right)$, but not with any measured environmental variables.

The position of the three dominant shrub species in ordination space, particularly the strong negative and positive associations of Lindera benzoin (FAC) and Cornus foemina (FACW) with Axis 1, suggests that the shrub community is strongly indicative of current hydrologic conditions. Lonicera maackii, the exotic shrub species, did not relate strongly with Axis 1. As shown in Appendix Fig. 10, stem density of L. maackii was generally highest at values of Axis 1 near zero. This may indicate at preference of $L$. maackii for areas with intermediate flooding intensity, such as those at Site 2, where this species achieved the highest mean density. 


\section{Shrub Distribution and Hydrology}

NMS results indicate that total shrub density responded negatively to increased flooding. However, this relationship appeared to vary by species, with Lindera benzoin, Lonicera maackii and Cornus foemina occupying different regions of an apparent hydrologic gradient. To directly examine the relationship between shrub density and days of flooding and differences in this relationship by species, I generated scatter plots and correlation coefficients for relationships between: 1) total shrub stem density vs. days flooded (Appendix Figure 11) and 2) shrub stem density (by species) vs. days flooded (Fig. 2-11). Correlation data are given in Table 2-11. Total shrub stem density was not significantly correlated with the number of flooded days $(\mathrm{p}=0.38)$. Considering the Ushaped distribution of data points in Appendix Fig. 11, this appears to be due entirely to the influence of Cornus foemina which increased in density with the number of days flooded $\left(\mathrm{r}^{2}=0.13, \mathrm{p}=0.007\right)$. The stem density of all other species decreased with the number of days flooded $(\mathrm{p} \leq 0.05)$. Of the four shrubs, Lindera benzoin persisted in the most narrow range of hydrologic conditions, and did not occur in transects with more than 28 days of flooding. It should be noted, however, that this species only occurred at one site, which had the most limited range of flooded days; thus its absence from transects with longer flooding durations may be limited by site factors, such as dispersal or other edaphic conditions. L. maackii and Rubus spp. had similar relationships with days flooded; they were found in transects with a relatively high number of flooded days, but did not increase in density with this factor. For clarity, it should be noted that "days flooded" is a property of the transect, and not a measure of how long an individual plant 
experienced flooding, because plants at higher elevations will experience fewer days of flooding than those at lower elevations, within a transect.

Because the invasive species Lonicera maackii was a species of special concern, I further examined the rank elevation of L. maackii individuals within parallel transects, and its relationship with the number of days flooded. If areas of raised elevation, in flooded areas, created safe sites for the establishment of L. maackii, it was expected that the rank elevation of plants in transects would increase with the number of flooded days. As seen in Fig. 2-12, plants in transects with $\sim 0-4$ total days of flooding occupied the full range of relative elevations within their respective transects. Individuals in transects flooded for approximately 5 days or more were constrained to increasingly higher relative elevations as the number of days flooded increased. Mature L. maackii plant stems (>2.0 $\mathrm{m}$ tall) persisted into a transect experiencing up to 43 days of flooding (during the water level monitoring period) by occupying the highest recorded elevation within that transect (Site 3-N1-30m). The number of flooding days in each transect where L. maackii was found, along with the relative elevations, stem numbers, and heights of individual plants are listed in Appendix Table 15.

\section{$\underline{\text { Discussion }}$}

The three most important tree species encountered in research sites were Fraxinus pennsylvanica (FACW), Acer rubrum (FAC), and Celtis laevigata (FACW). A. rubrum was the dominant adult species at all three sites. The second most important adult tree 
species in the intermediate and dry sites were $C$. laevigata and $F$. pennsylvanica. $\quad F$. pennsylvanica was extremely important across sites, and had the highest densities and/or importance values of any species in both the sapling and seedling layers, across sites. The sapling and seedling layers at the two drier sites indicate a growing importance of Celtis laevigata, a relatively short-lived, fast-growing species (Burns and Honkala 1990). This species is intolerant of flooding, particularly in the seedling stage; thus, this species reflects the hydrology of the two drier sites. Adult trees had higher species richness towards the forest edges, with most of the species unique to the edge being facultative upland species.

Findings from the NMS ordination suggest that the shrub community were most indicative of community differences among these three wetlands, and that these differences are primarily related to differences in hydrology. Importance values of shrubs at each site, and the location of these shrubs in ordination space, show that each site is associated with a different shrub species. L. benzoin (a native FAC shrub) and $C$. foemina (a native FACW shrub) were associated with the driest and wettest sites, respectively, while L. maackii (an invasive, exotic species) was associated with the intermediate site. L. maackii density at the two driest sites was significantly higher than at the wet site.

It was surprising that $L$. maackii had higher importance values and similar stem densities at the intermediate, rather than dry site. The majority of studies on L. maackii invasion in North America have been conducted in upland systems and I expected this species to be clearly associated with the driest habitat. This study shows that L. maackii has the ability to invade and gain dominance in wetland habitats. The association of $L$. 
maackii with relatively higher elevations in areas subjected to greater flooding indicates that microtopography is an important factor in facilitating invasion.

Interestingly, the intermediate and dry sites had similar densities of L. maackii, but differed in important ways. The driest site had a dense native shrub layer (dominated by L. benzoin) that persisted alongside L. maackii throughout the forest edge and interior. This is contrary to findings from other studies that have found a negative correlation between L. maackii and the diversity or species richness of other plant species. This offers some evidence that L. maackii, under certain circumstances, may add to the native shrub community, rather than replace it. Since the stem size class structure of L. maackii did not appear to be different between the intermediate and dry site, there is no evidence of a more recent, less established invasion at the dry site. One clue to the coexistence of L. benzoin and L. maackii at this site may lie in the forest canopy. Since this study sought out to minimize confounding effects of light availability from sources other than the forest edge, I chose transect locations with relatively closed canopies. Studies have shown that L. benzoin has maximum stem growth at $25 \%$ full sun photosynthetic photon flux density (PPFD), and that L. maackii has highest efficiency at a higher level of light availability (near 100\%). Thus, L. maackii is likely to outcompete L. benzoin in the presence of light-creating disturbances, where it can use increased light availability to achieve higher growth rates. Since we avoided large gaps, I may have encountered environmental conditions that supported a stable coexistence between $L$. benzoin and $L$. maackii. This could potentially be disrupted by the future creation of canopy gaps.

The importance of canopy gaps are particularly important to consider in the context of: 1) global climate change, where changing frequency of storms with damaging 
winds may affect the forest canopy (Peterson 2000), and 2) Emerald ash borer infestation, which affects Fraxinus species such as $F$. pennsylvanica, a dominant species in these wetlands. According to recent estimates, Emerald ash borer (EAB) infestations can kill a healthy ash stand with close to 100\% mortality within 6 years (USFS 2007). Healthy trees die within approximately 4 years of infestation. Saplings are also attacked by this beetle and can be killed in a single year (Poland and McCullough 2006), and may not be able to replace dead ash adults quickly via gap-filling While I have not assessed the impact of EAB on my study sites, it is hard to imagine a scenario where it does not fundamentally alter the environment of these forests in many different ways (i.e. increased canopy openness, increased temperatures, and decreased evapotranspiration resulting from loss of a dominant species), with resulting shifts in plant community structure.

While the driest site had the greatest species richness and diversity in most vegetation layers, many of the species unique to this site (particularly in the adult tree and shrub layers) were exotic species or FAC/FACU species. In other words, the greater number of species at the dry site did not come primarily from a greater number of native woody wetland species. This site also had the highest percent cover of the invasive woody vine, Lonicera japonica, which was the most important vine species at this site. There were no exotic, woody plant species that were found only at the wettest site. The susceptibility of the dry site to invasion may be encouraged by its residential setting, but is likely permitted by drier conditions. Although wetland systems have been cited as being particularly prone to the incursion of exotic, invasive plant species (Zedler and 
Kercher 2005), my study suggests that wetland hydrology offers some degree of protection from invasive, woody species.

Wetland managers should be mindful of L. maackii and other woody invaders when implementing restoration strategies. Microtopography in wetland forests is important because it facilitates the establishment of native species that require safe sites for germination in wetland areas (Battaglia et al. 2000, Blood and Titus 2010). Thus, the creation of microtopography (i.e. "pits and mounds") may be a goal of wetland restoration and management (Pietrzykowski et al. 2015, Kangas et al. 2016). However, my results suggest that the results of these efforts must be monitored closely, particularly in areas with relatively open canopy conditions, which may encourage the growth and spread of exotic species, such as L. maackii, that can take advantage of light-creating and topographical disturbances.

There is some evidence to suggest that $L$. maackii, once established in wetlands, may alter the environment to its benefit. A recent study by Boyce et al. (2012) suggests that evapotranspiration by L. maackii may cause a net soil water loss, thus drying the soil. In the context of wetland systems, this represents a potential positive feedback loop, whereby water losses via L. maackii evapotranspiration contribute to altered wetland hydrology, further facilitating the establishment and spread of this invasive species.

\section{Conclusions}

This field study sampled plant communities over a range of hydrologic conditions and varying distance from the forest edge in three forested wetlands. The shrub community was most indicative of differences in hydrology between sites. Based on 
results from this study and others (Swab et al. 2008), the invasive shrub Lonicera maackii can be expected to be more problematic in wetlands that have undergone hydrologic modifications, resulting in drier conditions. Because survival in wetland soils requires specialized adaptations, it is likely that wet conditions provide resistance to woody invaders from upland systems. However, the availability of more elevated "safe sites" (sensu Grubb 1977) may facilitate the colonization of wetland sites. Fraxinus pennsylvanica was a major component of the tree canopy at all study sites, and the losses of this species due to Emerald ash borer infestation are likely to have lasting consequences on plant community structure and composition in these forested wetlands. 
Table 2-1. Characteristics of the three research sites chosen for study, including area, soil type, soil flooding/ponding characteristics, and drainage class, according to the NRCS SSURGO dataset. All information, besides size, was verified by NRCS personnel in the field.

\begin{tabular}{|c|c|c|c|c|c|c|}
\hline $\begin{array}{c}\text { Site Numbers } \\
\text { and Names }\end{array}$ & $\begin{array}{l}\text { Area } \\
(\mathrm{Ha})\end{array}$ & Soil Map Unit & $\begin{array}{c}\text { Flooding or } \\
\text { Ponding Class }\end{array}$ & $\begin{array}{c}\text { Approx. } \\
\text { Elevation (feet) }\end{array}$ & " Drainage Class & Coordinates \\
\hline $\begin{array}{c}\text { Site } 2 \\
\text { Intermediate Site } \\
\text { (Evangel) }\end{array}$ & 15.1 & Zipp silty clay & Ponded & 451 & Poor & $\begin{array}{c}38^{\circ} 8^{\prime} 52.57^{\prime \prime} \mathrm{N} \\
85^{\circ} 42^{\prime} 36.01^{\prime \prime} \mathrm{W}\end{array}$ \\
\hline $\begin{array}{c}\text { Site } 1 \\
\text { Dry Site } \\
\text { (Max Sawyer) }\end{array}$ & 28.5 & Melvin silt loam & $\begin{array}{l}\text { Frequently } \\
\text { flooded }\end{array}$ & 456 & Poor & $\begin{array}{c}38^{\circ} 7^{\prime} 26.48^{\prime \prime} \mathrm{N} \\
85^{\circ} 41^{\prime} 58.86^{\prime \prime} \mathrm{W}\end{array}$ \\
\hline $\begin{array}{c}\text { Site } 3 \\
\text { Wet Site } \\
\text { (Trinity) }\end{array}$ & 31.1 & Zipp silty clay & Ponded & 459 & Very Poor & $\begin{array}{l}38^{\circ} 7^{\prime} 24.58^{\prime \prime N} \\
85^{\circ} 44^{\prime} 2.27^{\prime \prime} \mathrm{W}\end{array}$ \\
\hline
\end{tabular}


Table 2-2. Data used in ranking sites by wetness. Means at the scale of edge-to-interior transect $(\mathrm{N}=4$ per site), parallel transect, and site. Each edge-to-interior transect consisted of five parallel transects spaced at 1, 5, 10, 30 and 60 meters.

\begin{tabular}{|c|c|c|c|c|c|c|c|}
\hline \multirow{2}{*}{\multicolumn{2}{|c|}{$\begin{array}{cc} & \\
\begin{array}{c}\text { Edge-to- } \\
\text { Interior }\end{array} & \begin{array}{c}\text { Pransect } \\
\text { Transect } \\
\text { Tran from } \\
\text { edge })\end{array} \\
\end{array}$}} & \multirow{2}{*}{\multicolumn{2}{|c|}{$\begin{array}{l}\text { Site 1: Dry Site } \\
\text { Days Flooded } \\
\text { SE }\end{array}$}} & \multirow{2}{*}{\multicolumn{2}{|c|}{$\begin{array}{c}\text { Site 2: Intermediate } \\
\text { Site } \\
\text { Days Flooded } \\
\text { SE }\end{array}$}} & \multirow{2}{*}{\multicolumn{2}{|c|}{$\begin{array}{l}\text { Site 3: Wet Site } \\
\text { Days Flooded } \\
\text { SE }\end{array}$}} \\
\hline & & & & & & & \\
\hline N1 & 1 & ${ }^{\circ}$ & . & 10.3 & 3.4 & 0.0 & 0.0 \\
\hline N1 & 5 & . & . & 0.4 & 0.2 & 12.2 & 1.4 \\
\hline N1 & 10 & . & . & 10.7 & 0.4 & 33.3 & 7.7 \\
\hline N1 & 30 & . & . & 1.4 & 1.4 & 42.5 & 11.4 \\
\hline $\mathrm{N} 1$ & 60 & . & . & 3.0 & 1.3 & 36.5 & 1.4 \\
\hline \multicolumn{2}{|l|}{ Mean } & & & 5.2 & 2.2 & 24.9 & 8.1 \\
\hline $\mathrm{N} 2$ & 1 & 0.0 & 0.0 & 14.9 & 4.3 & 40.9 & 6.1 \\
\hline $\mathrm{N} 2$ & 5 & 0.0 & 0.0 & 10.9 & 5.1 & 55.0 & 1.6 \\
\hline $\mathrm{N} 2$ & 10 & 0.8 & 0.5 & 17.9 & 1.6 & 52.5 & 4.1 \\
\hline $\mathrm{N} 2$ & 30 & 28.1 & 11.3 & 33.5 & 14.1 & 47.6 & 2.8 \\
\hline $\mathrm{N} 2$ & 60 & 10.3 & 7.5 & 71.9 & 4.9 & 23.8 & 1.9 \\
\hline \multicolumn{2}{|l|}{ Mean } & 7.8 & 5.4 & 29.8 & 11.2 & 44.0 & 5.6 \\
\hline S1 & 1 & 0.0 & 0.0 & 32.6 & 6.2 & 2.6 & 1.1 \\
\hline $\mathrm{S} 1$ & 5 & 9.7 & 9.6 & 8.2 & 1.7 & 4.5 & 1.1 \\
\hline $\mathrm{S} 1$ & 10 & 0.0 & 0.0 & 15.3 & 4.2 & 6.2 & 0.5 \\
\hline $\mathrm{S} 1$ & 30 & 0.0 & 0.0 & 17.3 & 5.2 & 8.7 & 1.1 \\
\hline $\mathrm{S} 1$ & 60 & 0.9 & 0.7 & 34.4 & 4.1 & 2.2 & 0.4 \\
\hline \multicolumn{2}{|l|}{ Mean } & 2.1 & 1.9 & 21.6 & 5.1 & 4.8 & 1.2 \\
\hline $\mathrm{S} 2$ & 1 & 1.5 & 1.5 & 31.5 & 4.9 & 83.2 & 0.5 \\
\hline $\mathrm{S} 2$ & 5 & 4.1 & 1.8 & 5.4 & 1.2 & 84.5 & 0.4 \\
\hline $\mathrm{S} 2$ & 10 & 1.1 & 0.5 & 21.4 & 4.5 & 84.3 & 0.6 \\
\hline $\mathrm{S} 2$ & 30 & 0.6 & 0.6 & 33.9 & 3.6 & 84.2 & 0.5 \\
\hline $\mathrm{S} 2$ & 60 & 1.2 & 1.2 & 22.3 & 3.5 & 82.6 & 1.3 \\
\hline \multicolumn{2}{|l|}{ Mean } & 1.7 & 0.6 & 22.9 & 5.0 & 83.7 & 0.4 \\
\hline \multicolumn{2}{|c|}{ SITE MEAN $( \pm S E)$} & 3.9 & 1.9 & 19.9 & 3.7 & 39.4 & 7.6 \\
\hline
\end{tabular}


Table 2-3. Summary of measured environmental variables at the perpendicular transect level (N=4, within each site). Each edge-tointerior transect consisted of five parallel transects spaced at 1, 5, 10, 30 and 60 meters.

\begin{tabular}{|c|c|c|c|c|c|c|c|c|c|c|c|c|c|c|c|c|}
\hline \multirow{2}{*}{$\begin{array}{c}\text { Site } \\
\\
1\end{array}$} & \multirow{2}{*}{$\begin{array}{c}\begin{array}{c}\text { Edge-to-Interior } \\
\text { Transect }\end{array} \\
\text { N1 }\end{array}$} & \multirow{2}{*}{$\begin{array}{l}\mathrm{N} \\
\\
\\
5\end{array}$} & \multicolumn{2}{|c|}{$\begin{array}{c}\text { Days } \\
\text { Flooded } \\
\pm \mathrm{SE}\end{array}$} & \multicolumn{2}{|c|}{$\begin{array}{c}\% \text { Herb } \\
\text { Cover } \\
\pm \mathrm{SE}\end{array}$} & \multicolumn{2}{|c|}{$\begin{array}{c}\% \text { Bare Soil } \\
\pm \mathrm{SE}\end{array}$} & \multicolumn{2}{|c|}{$\begin{array}{c}\text { \% Leaf } \\
\text { Litter } \\
\pm \text { SE }\end{array}$} & \multicolumn{2}{|c|}{$\begin{array}{c}\% \mathrm{CWD} \\
\pm \mathrm{SE}\end{array}$} & \multicolumn{2}{|c|}{$\begin{array}{c}\text { \% Canopy } \\
\text { Closure } \\
\pm \mathrm{SE}\end{array}$} & \multicolumn{2}{|c|}{$\begin{array}{c}\% \text { LAI } \\
\pm \text { SE }\end{array}$} \\
\hline & & & . & . & 10 & 3 & 18 & 10 & 75 & 11 & 3 & 2 & 88 & 1 & 4.60 & 0.16 \\
\hline 1 & $\mathrm{~N} 2$ & 5 & 7.8 & 5.4 & 16 & 4 & 35 & 17 & 61 & 15 & 9 & 5 & 85 & 2 & 4.62 & 0.12 \\
\hline 1 & S1 & 5 & 2.1 & 1.9 & 22 & 10 & 21 & 16 & 77 & 16 & 1 & 1 & 92 & 0 & 4.09 & 0.15 \\
\hline 1 & S2 & 5 & 1.7 & 0.6 & 6 & 2 & 13 & 4 & 82 & 4 & 1 & 1 & 94 & 1 & 4.38 & 0.11 \\
\hline & SITE MEAN & 4 & 3.9 & 1.7 & 13.4 & 3.5 & 21.9 & 4.7 & 73.7 & 4.6 & 3.5 & 1.7 & 89.6 & 2.0 & 4.42 & 0.12 \\
\hline 2 & N1 & 5 & 5.2 & 2.2 & 41 & 12 & 6 & 2 & 85 & 7 & 3 & 1 & 95 & 1 & 2.51 & 0.18 \\
\hline 2 & $\mathrm{~N} 2$ & 5 & 29.8 & 11.2 & 72 & 6 & 9 & 3 & 87 & 4 & 6 & 5 & 88 & 2 & 2.63 & 0.17 \\
\hline 2 & S1 & 5 & 21.6 & 5.1 & 60 & 13 & 3 & 1 & 93 & 2 & 6 & 2 & 89 & 1 & 3.02 & 0.35 \\
\hline 2 & $\mathrm{~S} 2$ & 5 & 22.9 & 5.0 & 69 & 14 & 10 & 4 & 87 & 5 & 0 & 0 & 92 & 1 & 2.88 & 0.22 \\
\hline & SITE MEAN & 4 & 19.9 & 5.2 & 60.3 & 7.1 & 7.1 & 1.7 & 88.0 & 1.6 & 3.8 & 1.4 & 91.1 & 1.6 & 2.76 & 0.12 \\
\hline 3 & N1 & 5 & 24.9 & 8.1 & 51 & 15 & 6 & 3 & 93 & 3 & 1 & 1 & 90 & 2 & 4.13 & 0.38 \\
\hline 3 & $\mathrm{~N} 2$ & 5 & 44.0 & 5.6 & 61 & 11 & 3 & 0 & 98 & 0 & 0 & 0 & 89 & 3 & 3.89 & 0.11 \\
\hline 3 & S1 & 5 & 4.8 & 1.2 & 60 & 9 & 24 & 13 & 75 & 13 & 2 & 1 & 92 & 1 & 2.93 & 0.41 \\
\hline 3 & S2 & 5 & 83.7 & 0.4 & 54 & 17 & 73 & 9 & 23 & 9 & 5 & 3 & 85 & 2 & 4.24 & 0.21 \\
\hline & SITE MEAN & 4 & 39.4 & 16.8 & 56.4 & 2.5 & 26.2 & 16.1 & 72.3 & 17.0 & 1.8 & 1.0 & 89.0 & 1.5 & $\mathbf{3 . 8 0}$ & 0.30 \\
\hline
\end{tabular}


Table 2-4. Pearson correlations between environmental variables at the landscape scale (i.e. data for all transects at all sites included). Bold cells indicate pairs of variables with p-values $<0.05$. Top values in each cell are values for the correlation coefficient $r$, middle values are $\mathrm{p}$-values and bottom values indicate the sample size, $n$.

\begin{tabular}{|c|c|c|c|c|c|c|c|c|}
\hline & $\begin{array}{c}\text { Distance } \\
\text { from Edge }\end{array}$ & $\begin{array}{c}\text { Days } \\
\text { Flooded }\end{array}$ & $\begin{array}{c}\begin{array}{c}\% \text { Herb } \\
\text { Cover }\end{array}\end{array}$ & \% Bare Soil & $\begin{array}{c}\text { \% Leaf } \\
\text { Litter }\end{array}$ & \% \% CWD & $\begin{array}{c}\text { \% Canopy } \\
\text { Closure }\end{array}$ & 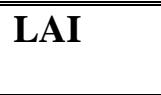 \\
\hline Distance from & 1.0000 & 0.1160 & -0.2107 & 0.0045 & -0.0103 & -0.0231 & 0.1039 & 0.0582 \\
\hline \multirow[t]{2}{*}{ Edge } & & 0.3992 & 0.1062 & 0.9730 & 0.9377 & 0.8607 & 0.4295 & 0.6590 \\
\hline & 60 & 55 & 60 & 60 & 60 & 60 & 60 & 60 \\
\hline \multirow[t]{3}{*}{ Days Flooded } & & 1.0000 & 0.3060 & 0.3542 & -0.3274 & -0.0026 & -0.3662 & 0.1163 \\
\hline & & & 0.0231 & 0.0080 & 0.0147 & 0.9852 & 0.0060 & 0.3978 \\
\hline & & 55 & 55 & 55 & 55 & 55 & 55 & 55 \\
\hline$\%$ Herb & & & 1.0000 & -0.0550 & 0.1242 & -0.1817 & -0.2136 & -0.6284 \\
\hline \multirow{2}{*}{ Cover } & & & & 0.6763 & 0.3443 & 0.1647 & 0.1013 & $<.0001$ \\
\hline & & & 60 & 60 & 60 & 60 & 60 & 60 \\
\hline \multirow[t]{3}{*}{$\%$ Bare Soil } & & & & 1.0000 & -0.9753 & 0.0534 & -0.2422 & 0.2465 \\
\hline & & & & & $<.0001$ & 0.6851 & 0.0622 & 0.0576 \\
\hline & & & & 60 & 60 & 60 & 60 & 60 \\
\hline \multirow[t]{3}{*}{ \% Leaf Litter } & & & & & 1.0000 & -0.1585 & 0.2187 & -0.2394 \\
\hline & & & & & & 0.2266 & 0.0932 & 0.0654 \\
\hline & & & & & 60 & 60 & 60 & 60 \\
\hline \multirow[t]{3}{*}{$\%$ CWD } & & & & & & 1.0000 & -0.1318 & 0.0956 \\
\hline & & & & & & & 0.3153 & 0.4673 \\
\hline & & & & & & 60 & 60 & 60 \\
\hline \% Canopy & & & & & & & 1.0000 & -0.1260 \\
\hline \multirow[t]{2}{*}{ Closure } & & & & & & & & 0.3374 \\
\hline & & & & & & & 60 & 60 \\
\hline LAI & & & & & & & & 1.0000 \\
\hline
\end{tabular}


Table 2-5. Mean density, IV and basal area \pm SE for the adult trees stratum $(>2.5 \mathrm{~cm} \mathrm{dbh})$ at each of the three research sites. This could not be determined for species identified to genus level only. N=8 12 x 12 m plots at each site. Species are organized alphabetically in groups first by those occurring at the wet, then intermediate, and lastly at the dry sites. WIS = Wetland Indicator Status (see Appendix Table 16 for categories). Values in bold show the species with the highest IV and density at each site .

\begin{tabular}{|c|c|c|c|c|c|c|c|c|c|c|c|c|c|c|c|c|c|c|c|}
\hline \multirow{3}{*}{$\begin{array}{l}\text { Species } \\
\text { Acer rubrum }\end{array}$} & \multirow{3}{*}{$\begin{array}{l}\text { WIS } \\
\text { Code } \\
\\
\text { FAC }\end{array}$} & \multicolumn{6}{|c|}{ Site 3: Wet Site } & \multicolumn{6}{|c|}{ Site 2: Intermediate Site } & \multicolumn{6}{|c|}{ Site 1: Dry Site } \\
\hline & & \multicolumn{2}{|c|}{$\begin{array}{c}\text { Mean } \\
\text { (stems/Ha) } \\
\pm \mathrm{SE}\end{array}$} & \multicolumn{2}{|c|}{$\begin{array}{l}\text { Mean IV } \\
\quad \pm \text { SE }\end{array}$} & \multicolumn{2}{|c|}{$\begin{array}{c}\text { Mean Basal } \\
\text { area }\left(\mathrm{m}^{2} / \mathrm{Ha}\right) \\
\quad \pm \mathrm{SE}\end{array}$} & \multicolumn{2}{|c|}{$\begin{array}{c}\text { Mean } \\
\text { (stems/Ha) } \\
\pm \mathrm{SE}\end{array}$} & \multicolumn{2}{|c|}{$\begin{array}{c}\text { Mean IV } \\
\pm \text { SE }\end{array}$} & \multicolumn{2}{|c|}{$\begin{array}{c}\text { Mean Basal } \\
\text { area }\left(\mathrm{m}^{2} / \mathrm{Ha}\right) \\
\pm \mathrm{SE}\end{array}$} & \multicolumn{2}{|c|}{$\begin{array}{c}\text { Mean } \\
\text { (stems/Ha) } \\
\pm \mathrm{SE}\end{array}$} & \multicolumn{2}{|c|}{$\begin{array}{l}\text { Mean IV } \\
\quad \pm \text { SE }\end{array}$} & \multicolumn{2}{|c|}{$\begin{array}{c}\text { Mean Basal } \\
\text { area } \\
\left(\mathrm{m}^{2} / \mathrm{Ha}\right) \\
\pm \mathrm{SE}\end{array}$} \\
\hline & & 833 & 315 & 35.1 & 6.5 & 11.4 & 2.6 & 356 & 74 & 31.8 & 4.1 & 18.4 & 4.5 & 590 & 156 & 40.6 & 4.9 & 20.9 & 3.7 \\
\hline $\begin{array}{c}\text { Acer } \\
\text { saccharinum }\end{array}$ & FACW & 26 & 18 & 0.9 & 0.7 & 0.2 & 0.1 & 0 & 0 & 0.0 & 0.0 & 0.0 & 0.0 & 0 & 0 & 0.0 & 0.0 & 0.0 & 0.0 \\
\hline Celtis laevigata & FACW & 286 & 197 & 12.3 & 8.1 & 2.8 & 1.9 & 530 & 131 & 24.2 & 5.0 & 4.4 & 1.2 & 35 & 19 & 3.2 & 2.7 & 1.3 & 1.3 \\
\hline $\begin{array}{l}\text { Diospyros } \\
\text { virginiana }\end{array}$ & FAC & 26 & 18 & 0.5 & 0.4 & 0.0 & 0.0 & 0 & 0 & 0.0 & 0.0 & 0.0 & 0.0 & 0 & 0 & 0.0 & 0.0 & 0.0 & 0.0 \\
\hline $\begin{array}{c}\text { Fraxinus } \\
\text { pennsylvanica }\end{array}$ & FACW & 503 & 162 & 20.9 & 4.4 & 7.0 & 1.8 & 208 & 73 & 14.7 & 4.5 & 7.2 & 2.8 & 313 & 114 & 23.0 & 6.2 & 10.4 & 2.9 \\
\hline $\begin{array}{l}\text { Liquidambar } \\
\text { styraciflua }\end{array}$ & FAC & 43 & 22 & 5.4 & 3.7 & 3.1 & 2.7 & 0 & 0 & 0.0 & 0.0 & 0.0 & 0.0 & 130 & 59 & 8.6 & 4.9 & 5.8 & 5.2 \\
\hline Nyssa sylvatica & FAC & 69 & 69 & 3.3 & 3.3 & 0.4 & 0.4 & 0 & 0 & 0.0 & 0.0 & 0.0 & 0.0 & 17 & 17 & 1.1 & 1.1 & 0.6 & 0.6 \\
\hline $\begin{array}{l}\text { Populus } \\
\text { deltoides }\end{array}$ & FAC & 26 & 18 & 1.1 & 0.7 & 0.3 & 0.2 & 61 & 36 & 7.6 & 5.1 & 5.7 & 4.6 & 17 & 11 & 1.0 & 0.8 & 0.5 & 0.5 \\
\hline $\begin{array}{l}\text { Quercus } \\
\text { bicolor }\end{array}$ & FACW & 26 & 18 & 2.4 & 2.0 & 0.9 & 0.9 & 9 & 9 & 0.2 & 0.2 & 0.0 & 0.0 & 0 & 0 & 0.0 & 0.0 & 0.0 & 0.0 \\
\hline $\begin{array}{l}\text { Quercus } \\
\text { palustris }\end{array}$ & FACW & 200 & 142 & 9.9 & 4.6 & 3.7 & 2.0 & 43 & 22 & 4.8 & 3.8 & 5.2 & 5.0 & 17 & 11 & 1.3 & 0.9 & 0.2 & 0.2 \\
\hline Salix nigra & OBL & 26 & 26 & 1.9 & 1.9 & 0.5 & 0.5 & 0 & 0 & 0.0 & 0.0 & 0.0 & 0.0 & 0 & 0 & 0.0 & 0.0 & 0.0 & 0.0 \\
\hline Ulmus rubra & FAC & 122 & 31 & 6.3 & 1.7 & 2.2 & 1.1 & 226 & 93 & 11.3 & 4.4 & 2.8 & 1.4 & 122 & 52 & 6.1 & 3.6 & 0.6 & 0.3 \\
\hline Acer negundo & FAC & 0 & 0 & 0.0 & 0.0 & 0.0 & 0.0 & 17 & 11 & 0.7 & 0.5 & 0.1 & 0.1 & 0 & 0 & 0.0 & 0.0 & 0.0 & 0.0 \\
\hline $\begin{array}{c}\text { Platanus } \\
\text { occidentalis }\end{array}$ & FACW & 0 & 0 & 0.0 & 0.0 & 0.0 & 0.0 & 9 & 9 & 2.5 & 2.5 & 1.5 & 1.5 & 104 & 37 & 9.6 & 5.2 & 4.2 & 1.9 \\
\hline Quercus lyrata & OBL & 0 & 0 & 0.0 & 0.0 & 0.0 & 0.0 & 9 & 9 & 2.1 & 2.1 & 0.9 & 0.9 & 0 & 0 & 0.0 & 0.0 & 0.0 & 0.0 \\
\hline Carya sp. & - & 0 & 0 & 0.0 & 0.0 & 0.0 & 0.0 & 0 & 0 & 0.0 & 0.0 & 0.0 & 0.0 & 9 & 9 & 0.2 & 0.2 & 0.0 & 0.0 \\
\hline Cornus florida & FACU & 0 & 0 & 0.0 & 0.0 & 0.0 & 0.0 & 0 & 0 & 0.0 & 0.0 & 0.0 & 0.0 & 9 & 9 & 0.2 & 0.2 & 0.0 & 0.0 \\
\hline
\end{tabular}




\begin{tabular}{|c|c|c|c|c|c|c|c|c|c|c|c|c|c|c|c|c|c|c|c|}
\hline \multirow{3}{*}{$\begin{array}{c}\text { Species } \\
\\
\text { Fagus } \\
\text { grandifolia }\end{array}$} & \multirow{3}{*}{$\begin{array}{c}\text { WIS } \\
\text { Code } \\
\text { FACU }\end{array}$} & \multicolumn{6}{|c|}{ Site 3: Wet Site } & \multicolumn{6}{|c|}{ Site 2: Intermediate Site } & \multicolumn{6}{|c|}{ Site 1: Dry Site } \\
\hline & & \multicolumn{2}{|c|}{$\begin{array}{c}\text { Mean } \\
\text { (stems/Ha) } \\
\pm \mathrm{SE}\end{array}$} & \multicolumn{2}{|c|}{$\begin{array}{c}\text { Mean IV } \\
\pm \text { SE }\end{array}$} & \multicolumn{2}{|c|}{$\begin{array}{c}\text { Mean Basal } \\
\text { area }\left(\mathrm{m}^{2} / \mathrm{Ha}\right) \\
\pm \mathrm{SE}\end{array}$} & \multicolumn{2}{|c|}{$\begin{array}{c}\text { Mean } \\
\text { (stems/Ha) } \\
\pm \mathrm{SE}\end{array}$} & \multicolumn{2}{|c|}{$\begin{array}{c}\text { Mean IV } \\
\pm \text { SE }\end{array}$} & \multicolumn{2}{|c|}{$\begin{array}{c}\text { Mean Basal } \\
\text { area }\left(\mathrm{m}^{2} / \mathrm{Ha}\right) \\
\pm \mathrm{SE}\end{array}$} & \multicolumn{2}{|c|}{$\begin{array}{c}\text { Mean } \\
\text { (stems/Ha) } \\
\pm \mathrm{SE}\end{array}$} & \multicolumn{2}{|c|}{$\begin{array}{c}\text { Mean IV } \\
\pm \text { SE }\end{array}$} & \multicolumn{2}{|c|}{$\begin{array}{c}\text { Mean Basal } \\
\text { area } \\
\left(\mathrm{m}^{2} / \mathrm{Ha}\right) \\
\pm \mathrm{SE}\end{array}$} \\
\hline & & 0 & 0 & 0.0 & 0.0 & 0.0 & 0.0 & 0 & 0 & 0.0 & 0.0 & 0.0 & 0.0 & 9 & 9 & 0.2 & 0.2 & 0.0 & 0.0 \\
\hline $\begin{array}{l}\text { Juniperus } \\
\text { virginiana }\end{array}$ & FACU & 0 & 0 & 0.0 & 0.0 & 0.0 & 0.0 & 0 & 0 & 0.0 & 0.0 & 0.0 & 0.0 & 17 & 17 & 0.6 & 0.6 & 0.3 & 0.3 \\
\hline $\begin{array}{c}\text { Ulmus } \\
\text { americana }\end{array}$ & FACW & 0 & 0 & 0.0 & 0.0 & 0.0 & 0.0 & 0 & 0 & 0.0 & 0.0 & 0.0 & 0.0 & 17 & 11 & 1.6 & 1.0 & 0.9 & 0.6 \\
\hline TOTAL & & 2188 & & 100 & & 32.5 & 4.1 & 1467 & & 100 & & 46.2 & 5.4 & 1458 & & 100 & & 47.1 & 5.1 \\
\hline
\end{tabular}


Table 2-6. Mean species richness (number of species) and Shannon-Weiner diversity values $(\mathrm{H})$ for all vegetation layers, averaged at the site level over all parallel transects $\left(16 \mathrm{~m}^{2} /\right.$ transect $)$ or adult sampling plots $\left(144 \mathrm{~m}^{2} / \mathrm{plot}\right)$. Values in bold indicate which site had the highest values of richness or $\mathrm{H}$ occurring within each vegetation layer.

\begin{tabular}{ccccccc}
\hline \hline Layer & Site & $\mathrm{N}$ & \multicolumn{2}{c}{ Mean Richness \pm SE } & \multicolumn{2}{c}{ Mean H \pm SE } \\
\hline Adult tree & 1: Dry Site & 8 & $\mathbf{5 . 7 5}$ & 1.01 & 1.12 & 0.14 \\
Adult tree & 2: Intermediate Site & 8 & 4.75 & 0.41 & 1.08 & 0.10 \\
Adult tree & 3: Wet Site & 8 & 5.25 & 0.56 & $\mathbf{1 . 2 7}$ & 0.11 \\
\hline Sapling & 1: Dry Site & 20 & $\mathbf{3 . 6 5}$ & 0.44 & $\mathbf{1 . 0 8}$ & 0.09 \\
Sapling & 2: Intermediate Site & 20 & 2.75 & 0.32 & 0.73 & 0.10 \\
Sapling & 3: Wet Site & 20 & 3.40 & 0.42 & 0.82 & 0.11 \\
\hline Tree Seedling & 1: Dry Site & 20 & $\mathbf{2 . 2 5}$ & 0.30 & $\mathbf{0 . 6 0}$ & 0.12 \\
Tree Seedling & 2: Intermediate Site & 20 & 1.85 & 0.27 & 0.44 & 0.10 \\
Tree Seedling & 3: Wet Site & 20 & 2.1 & 0.27 & 0.43 & 0.10 \\
\hline Shrubs & 1: Dry Site & 20 & $\mathbf{7 . 2 5}$ & 0.68 & $\mathbf{0 . 7 9}$ & 0.08 \\
Shrubs & 2: Intermediate Site & 20 & 2.30 & 0.52 & 0.21 & 0.07 \\
Shrubs & 3: Wet Site & 20 & 3.35 & 0.80 & 0.31 & 0.08 \\
\hline Vines & 1: Dry Site & 20 & $\mathbf{4 . 7 5}$ & 0.35 & $\mathbf{0 . 9 9}$ & 0.10 \\
Vines & 2: Intermediate Site & 20 & 3.25 & 0.32 & 0.52 & 0.08 \\
Vines & 3: Wet Site & 20 & 2.35 & 0.32 & 0.42 & 0.09 \\
\hline \hline
\end{tabular}


Table 2-7. Tree sapling ( $<2.5 \mathrm{~cm}$ dbh, $>1 \mathrm{~m}$ in height) abundance summaries by species for each forested wetland site. Abundance data are given as mean frequency across transects within site, sapling density, and IV $( \pm$ SE) at each site. Species are organized alphabetically in groups first by those occurring at the wet, then intermediate, and lastly at the dry sites. WIS = Wetland Indicator Status (see Appendix Table 16 for categories). Values in bold show the species with the highest IV and density at each site.

\begin{tabular}{|c|c|c|c|c|c|c|c|c|c|c|c|c|c|c|c|c|c|c|c|}
\hline \multirow{3}{*}{$\begin{array}{l}\text { Species Name } \\
\text { Acer rubrum }\end{array}$} & \multirow{3}{*}{$\begin{array}{l}\text { WIS } \\
\text { FAC }\end{array}$} & \multicolumn{6}{|c|}{ Site 3: Wet Site } & \multicolumn{6}{|c|}{ Site 2: Intermediate Site } & \multicolumn{6}{|c|}{ Site 1: Dry Site } \\
\hline & & \multicolumn{2}{|c|}{$\begin{array}{l}\text { Freq. } \\
\pm \mathrm{SE}\end{array}$} & \multicolumn{2}{|c|}{$\begin{array}{c}\text { Density } \\
\text { (stems/Ha) } \\
\pm \mathrm{SE}\end{array}$} & \multicolumn{2}{|c|}{$\begin{array}{c}\text { IV } \\
\pm \mathrm{SE}\end{array}$} & \multicolumn{2}{|c|}{$\begin{array}{l}\text { Freq. } \\
\pm \mathrm{SE}\end{array}$} & \multicolumn{2}{|c|}{$\begin{array}{c}\text { Density } \\
\text { (stems/Ha) } \\
\pm \mathrm{SE}\end{array}$} & \multicolumn{2}{|c|}{$\begin{array}{c}\text { IV } \\
\pm \text { SE }\end{array}$} & \multicolumn{2}{|c|}{$\begin{array}{l}\text { Freq. } \\
\pm \mathrm{SE}\end{array}$} & \multicolumn{2}{|c|}{$\begin{array}{c}\text { Density } \\
\text { (stems/Ha) } \\
\pm \mathrm{SE}\end{array}$} & \multicolumn{2}{|c|}{$\begin{array}{c}\text { IV } \\
\pm \mathrm{SE}\end{array}$} \\
\hline & & 0.33 & 0.08 & 1406 & 368 & 22.7 & 6.4 & 0.06 & 0.03 & 375 & 281 & 4.0 & 1.9 & 0.08 & 0.04 & 281 & 190 & 4.7 & 2.5 \\
\hline Acer saccharinum & FACW & 0.01 & 0.01 & 31 & 31 & 0.2 & 0.2 & 0.01 & 0.01 & 31 & 31 & 0.2 & 0.2 & 0.01 & 0.01 & 31 & 31 & 0.3 & 0.3 \\
\hline Celtis laevigata & FACW & 0.11 & 0.06 & 438 & 198 & 6.1 & 3.2 & 0.41 & 0.08 & 2500 & 596 & 37.0 & 6.7 & 0.19 & 0.06 & 563 & 186 & 15.0 & 4.7 \\
\hline Crategus spp. & & 0.01 & 0.01 & 31 & 31 & 0.3 & 0.3 & 0.01 & 0.01 & 31 & 31 & 0.7 & 0.7 & 0.00 & 0.00 & 0 & 0 & 0.0 & 0.0 \\
\hline $\begin{array}{c}\text { Fraxinus } \\
\text { pennsylvanica }\end{array}$ & FACW & 0.44 & 0.08 & 5844 & 2083 & 35.1 & 6.4 & 0.28 & 0.08 & 4063 & 2079 & 18.5 & 4.6 & 0.29 & 0.06 & 1250 & 339 & 22.4 & 3.4 \\
\hline $\begin{array}{l}\text { Liquidambar } \\
\text { styraciflua }\end{array}$ & FAC & 0.13 & 0.07 & 1469 & 855 & 3.7 & 2.1 & 0.00 & 0.00 & 0 & 0 & 0.0 & 0.0 & 0.15 & 0.06 & 469 & 226 & 10.6 & 4.1 \\
\hline $\begin{array}{l}\text { Liriodendron } \\
\text { tulipifera }\end{array}$ & FACU & 0.03 & 0.02 & 63 & 43 & 0.4 & 0.3 & 0.00 & 0.00 & 0 & 0 & 0.0 & 0.0 & 0.00 & 0.00 & 0 & 0 & 0.0 & 0.0 \\
\hline Unidentified & & 0.01 & 0.01 & 31 & 31 & 0.4 & 0.4 & 0.00 & 0.00 & 0 & 0 & 0.0 & 0.0 & 0.04 & 0.02 & 94 & 51 & 1.5 & 1.0 \\
\hline Nyssa sylvatica & FAC & 0.13 & 0.07 & 1094 & 689 & 3.2 & 1.8 & 0.00 & 0.00 & 0 & 0 & 0.0 & 0.0 & 0.00 & 0.00 & 0 & 0 & 0.0 & 0.0 \\
\hline Quercus bicolor & FACW & 0.03 & 0.02 & 63 & 43 & 0.6 & 0.4 & 0.03 & 0.02 & 63 & 43 & 1.4 & 1.0 & 0.01 & 0.01 & 31 & 31 & 1.3 & 1.3 \\
\hline Quercus michauxii & FACW & 0.03 & 0.02 & 63 & 43 & 5.2 & 5.0 & 0.00 & 0.00 & 0 & 0 & 0.0 & 0.0 & 0.06 & 0.03 & 156 & 77 & 3.5 & 1.6 \\
\hline Quercus palustris & FACW & 0.29 & 0.06 & 969 & 254 & 14.0 & 3.4 & 0.20 & 0.06 & 875 & 322 & 11.0 & 2.9 & 0.13 & 0.04 & 375 & 160 & 9.1 & 3.1 \\
\hline Ulmus rubra & FAC & 0.18 & 0.06 & 594 & 220 & 8.0 & 3.0 & 0.20 & 0.07 & 625 & 227 & 14.8 & 5.6 & 0.20 & 0.05 & 688 & 181 & 14.8 & 3.8 \\
\hline Diospyros virginiana & FAC & 0.00 & 0.00 & 0 & 0 & 0.0 & 0.0 & 0.01 & 0.01 & 31 & 31 & 0.9 & 0.9 & 0.01 & 0.01 & 31 & 31 & 0.3 & 0.3 \\
\hline Salix nigra & OBL & 0.00 & 0.00 & 0 & 0 & 0.0 & 0.0 & 0.01 & 0.01 & 125 & 125 & 1.5 & 1.5 & 0.00 & 0.00 & 0 & 0 & 0.0 & 0.0 \\
\hline Asimina triloba & FAC & 0.00 & 0.00 & 0 & 0 & 0.0 & 0.0 & 0.00 & 0.00 & 0 & 0 & 0.0 & 0.0 & 0.08 & 0.04 & 469 & 283 & 7.4 & 4.0 \\
\hline Carya spp. & & 0.00 & 0.00 & 0 & 0 & 0.0 & 0.0 & 0.00 & 0.00 & 0 & 0 & 0.0 & 0.0 & 0.03 & 0.02 & 63 & 43 & 1.3 & 0.9 \\
\hline Platanus occidentalis & FACW & 0.00 & 0.00 & 0 & 0 & 0.0 & 0.0 & 0.00 & 0.00 & 0 & 0 & 0.0 & 0.0 & 0.01 & 0.01 & 31 & 31 & 1.7 & 1.7 \\
\hline Prunus spp. & & 0.00 & 0.00 & 0 & 0 & 0.0 & 0.0 & 0.00 & 0.00 & 0 & 0 & 0.0 & 0.0 & 0.01 & 0.01 & 31 & 31 & 0.8 & 0.8 \\
\hline Sassafras albidum & FACU & 0.00 & 0.00 & 0 & 0 & 0.0 & 0.0 & 0.00 & 0.00 & 0 & 0 & 0.0 & 0.0 & 0.01 & 0.01 & 31 & 31 & 0.3 & 0.3 \\
\hline & SUM & & & 12094 & \pm 3273 & 100 & & & & 8719 & 2656 & 90 & & & & 4594 & 4593 & 95 & \\
\hline
\end{tabular}


Table 2-8. Tree seedling ( $<0.3 \mathrm{~m}$ tall) abundance summaries by research site. Abundance data are given as mean frequency, density, and IV $( \pm$ SE) at each site. Species are organized alphabetically in groups first by those occurring at the wet, then intermediate, and lastly at the dry sites. WIS = Wetland Indicator Status (see Appendix Table 16 for categories). Values in bold show the species with the highest IV and density at each site.

\begin{tabular}{|c|c|c|c|c|c|c|c|c|c|c|c|c|c|c|c|c|c|c|c|c|c|c|c|c|}
\hline \multirow[b]{2}{*}{ Species } & \multicolumn{6}{|c|}{ Site 3: Wet Site } & \multicolumn{6}{|c|}{ Site 2: Intermediate Site } & \multicolumn{6}{|c|}{ Site 1: Dry Site } & \multicolumn{6}{|c|}{ Across Site Means } \\
\hline & \multicolumn{2}{|c|}{$\begin{array}{c}\text { Mean } \\
\text { Freq. } \pm \text { SE }\end{array}$} & \multicolumn{2}{|c|}{$\begin{array}{c}\text { Mean } \\
\text { Density } \\
\text { (stems/ha) } \\
\pm \text { SE }\end{array}$} & \multicolumn{2}{|c|}{$\begin{array}{c}\text { Mean IV } \\
\pm \mathrm{SE}\end{array}$} & \multicolumn{2}{|c|}{$\begin{array}{c}\text { Mean } \\
\text { Freq. } \pm \text { SE }\end{array}$} & \multicolumn{2}{|c|}{$\begin{array}{c}\text { Mean } \\
\text { Density } \\
\text { (stems/ha) } \\
\pm \mathrm{SE}\end{array}$} & \multicolumn{2}{|c|}{$\begin{array}{c}\text { Mean IV } \\
\pm \mathrm{SE}\end{array}$} & \multicolumn{2}{|c|}{$\begin{array}{l}\text { Mean } \\
\text { Freq. } \\
\pm \mathrm{SE}\end{array}$} & \multicolumn{2}{|c|}{$\begin{array}{c}\text { Mean } \\
\text { Density } \\
\text { (stems/ha) } \\
\pm \mathrm{SE}\end{array}$} & \multicolumn{2}{|c|}{$\begin{array}{c}\text { Mean IV } \\
\pm \mathrm{SE}\end{array}$} & \multicolumn{2}{|c|}{$\begin{array}{c}\text { Mean } \\
\text { Freq. } \pm \text { SE }\end{array}$} & \multicolumn{2}{|c|}{$\begin{array}{c}\text { Mean } \\
\text { Density } \\
\text { (stems/ha) } \\
\pm \text { SE }\end{array}$} & \multicolumn{2}{|c|}{$\begin{array}{c}\text { Mean IV } \\
\pm \mathrm{SE}\end{array}$} \\
\hline Acer spp. & 0.03 & 0.02 & 63 & 43 & 3.8 & 2.7 & 0.00 & 0.00 & 0 & 0 & 0.0 & 0.0 & 0.0 & 0.0 & 0 & 0 & 0.0 & 0.0 & 0.01 & 0.01 & 21 & 21 & 1.3 & 1.3 \\
\hline $\begin{array}{c}\text { Celtis } \\
\text { laevigata }\end{array}$ & 0.01 & 0.01 & 31 & 31 & 2.1 & 2.1 & 0.13 & 0.03 & 625 & 198 & 24.7 & 7.2 & 0.1 & 0.0 & 719 & 199 & 24.5 & 7.2 & 0.09 & 0.04 & 458 & 215 & 17.1 & 7.5 \\
\hline $\begin{array}{c}\text { Fraxinus } \\
\text { pennsylvanica }\end{array}$ & 0.19 & 0.02 & 5188 & 1518 & 47.8 & 7.8 & 0.14 & 0.03 & 4688 & 2290 & 32.6 & 7.5 & 0.1 & 0.0 & 1188 & 471 & 25.9 & 7.5 & 0.15 & 0.02 & 3688 & 1258 & 35.4 & 6.5 \\
\hline $\begin{array}{c}\text { Liquidambar } \\
\text { styraciflua }\end{array}$ & 0.05 & 0.02 & 313 & 154 & 4.5 & 2.2 & 0.00 & 0.00 & 0 & 0 & 0.0 & 0.0 & 0.1 & 0.0 & 281 & 147 & 7.5 & 3.6 & 0.03 & 0.02 & 198 & 99 & 4.0 & 2.2 \\
\hline $\begin{array}{c}\text { Nyssa } \\
\text { sylvatica }\end{array}$ & 0.05 & 0.02 & 125 & 57 & 11.5 & 6.8 & 0.00 & 0.00 & 0 & 0 & 0.0 & 0.0 & 0.0 & 0.0 & 0 & 0 & 0.0 & 0.0 & 0.02 & 0.02 & 42 & 42 & 3.8 & 3.8 \\
\hline $\begin{array}{l}\text { Quercus } \\
\text { palustris }\end{array}$ & 0.15 & 0.03 & 1188 & 505 & 20.2 & 5.3 & 0.11 & 0.03 & 375 & 105 & 19.5 & 6.2 & 0.1 & 0.0 & 188 & 102 & 7.0 & 3.7 & 0.10 & 0.03 & 583 & 307 & 15.6 & 4.3 \\
\hline Ulmus rubra & 0.05 & 0.02 & 250 & 139 & 5.2 & 2.8 & 0.05 & 0.02 & 281 & 190 & 4.7 & 2.3 & 0.1 & 0.0 & 156 & 62 & 9.9 & 5.3 & 0.05 & 0.00 & 229 & 38 & 6.6 & 1.7 \\
\hline $\begin{array}{l}\text { Diospyros } \\
\text { virginiana }\end{array}$ & 0.00 & 0.00 & 0 & 0 & 0.0 & 0.0 & 0.03 & 0.02 & 63 & 43 & 1.9 & 1.4 & 0.0 & 0.0 & 31 & 31 & 1.0 & 1.0 & 0.01 & 0.01 & 31 & 18 & 1.0 & 0.6 \\
\hline Prunus spp. & 0.00 & 0.00 & 0 & 0 & 0.0 & 0.0 & 0.01 & 0.01 & 31 & 31 & 1.7 & 1.7 & 0.0 & 0.0 & 31 & 31 & 5.0 & 5.0 & 0.01 & 0.00 & 21 & 10 & 2.2 & 1.5 \\
\hline $\begin{array}{c}\text { Asimina } \\
\text { triloba }\end{array}$ & 0.00 & 0.00 & 0 & 0 & 0.0 & 0.0 & 0.00 & 0.00 & 0 & 0 & 0.0 & 0.0 & 0.0 & 0.0 & 31 & 31 & 1.0 & 1.0 & 0.00 & 0.00 & 10 & 10 & 0.3 & 0.3 \\
\hline Carya sp. & 0.00 & 0.00 & 0 & 0 & 0.0 & 0.0 & 0.00 & 0.00 & 0 & 0 & 0.0 & 0.0 & 0.0 & 0.0 & 63 & 43 & 4.4 & 3.0 & 0.01 & 0.01 & 21 & 21 & 1.5 & 1.5 \\
\hline $\begin{array}{c}\text { Liriodendron } \\
\text { tulipifera }\end{array}$ & 0.00 & 0.00 & 0 & 0 & 0.0 & 0.0 & 0.00 & 0.00 & 0 & 0 & 0.0 & 0.0 & 0.0 & 0.0 & 31 & 31 & 0.8 & 0.8 & 0.00 & 0.00 & 10 & 10 & 0.3 & 0.3 \\
\hline $\begin{array}{l}\text { Quercus } \\
\text { michauxii }\end{array}$ & 0.00 & 0.00 & 0 & 0 & 0.0 & 0.0 & 0.00 & 0.00 & 0 & 0 & 0.0 & 0.0 & 0.0 & 0.0 & 94 & 51 & 3.8 & 2.1 & 0.01 & 0.01 & 31 & 31 & 1.3 & 1.3 \\
\hline Rosaceae & 0.00 & 0.00 & 0 & 0 & 0.0 & 0.0 & 0.00 & 0.00 & 0 & 0 & 0.0 & 0.0 & 0.0 & 0.0 & 31 & 31 & 1.0 & 1.0 & 0.00 & 0.00 & 10 & 10 & 0.3 & 0.3 \\
\hline Unidentified & 0.00 & 0.00 & 0 & 0 & 0.0 & 0.0 & 0.00 & 0.00 & 0 & 0 & 0.0 & 0.0 & 0.0 & 0.0 & 63 & 43 & 3.1 & 2.2 & 0.01 & 0.01 & 21 & 21 & 1.0 & 1.0 \\
\hline SUM & & & 7156 & 1855 & 95 & & & & 6063 & 2431 & 85 & & & & 2906 & 644 & 95 & & & & 5375 & 2899 & & \\
\hline
\end{tabular}


Table 2-9. Shrub abundance summaries by research site. Abundance data are given as mean frequency, stem density, and IV ( \pm SE) at each site. Species sorted alphabetically by name by those occurring in Site 3, 2, and 1, in order. WIS = Wetland Indicator Status (see Appendix Table 16 for categories).Values in bold show the species with the highest IV and density at each site.

\begin{tabular}{|c|c|c|c|c|c|c|c|c|c|c|c|c|c|c|c|c|c|c|c|}
\hline \multirow[b]{2}{*}{ Species } & \multirow[b]{2}{*}{ WIS } & \multicolumn{6}{|c|}{ Site 3: Wet Site } & \multicolumn{6}{|c|}{ Site 2: Intermediate Site } & \multicolumn{6}{|c|}{ Site 1: Dry Site } \\
\hline & & \multicolumn{2}{|c|}{$\begin{array}{l}\text { Freq. } \\
\pm \text { SE }\end{array}$} & \multicolumn{2}{|c|}{$\begin{array}{c}\text { IV } \\
\pm \mathrm{SE}\end{array}$} & \multicolumn{2}{|c|}{$\begin{array}{c}\text { Density } \\
\text { (stems/Ha) } \\
\pm \mathrm{SE}\end{array}$} & \multicolumn{2}{|c|}{$\begin{array}{l}\text { Freq. } \\
\pm \mathrm{SE}\end{array}$} & \multicolumn{2}{|c|}{$\begin{array}{c}\text { IV } \\
\pm \mathrm{SE}\end{array}$} & \multicolumn{2}{|c|}{$\begin{array}{c}\text { Density } \\
\text { (stems/Ha) } \\
\pm \mathrm{SE}\end{array}$} & \multicolumn{2}{|c|}{$\begin{array}{l}\text { Freq. } \\
\pm \mathrm{SE}\end{array}$} & \multicolumn{2}{|c|}{$\begin{array}{c}\text { IV } \\
\pm \mathrm{SE}\end{array}$} & \multicolumn{2}{|c|}{$\begin{array}{c}\text { Density } \\
\text { (stems/Ha) } \\
\pm \mathrm{SE}\end{array}$} \\
\hline $\begin{array}{c}\text { Aralia } \\
\text { spinosa }\end{array}$ & FAC & 0.01 & 0.01 & 0.5 & 0.5 & 94 & 94 & 0.00 & 0.00 & 0.0 & 0.0 & 0 & 0 & 0.00 & 0.00 & 0.0 & 0.0 & 0 & 0 \\
\hline $\begin{array}{l}\text { Cephalanthus } \\
\text { occidentalis }\end{array}$ & OBL & 0.08 & 0.03 & 6.5 & 3.3 & 281 & 124 & 0.00 & 0.00 & 0.0 & 0.0 & 0 & 0 & 0.00 & 0.00 & 0.0 & 0.0 & 0 & 0 \\
\hline $\begin{array}{l}\text { Cornus } \\
\text { foemina }\end{array}$ & FACW & 0.29 & 0.07 & 40.1 & 8.7 & 6031 & 2842 & 0.15 & 0.06 & 21.0 & 8.0 & 3375 & 2260 & 0.08 & 0.04 & 3.3 & 1.8 & 1031 & 605 \\
\hline $\begin{array}{c}\text { Lonicera } \\
\text { maackii }\end{array}$ & NI & 0.10 & 0.04 & 12.6 & 5.7 & 813 & 458 & 0.31 & 0.07 & 43.1 & 9.5 & 4844 & 1256 & 0.39 & 0.07 & 18.8 & 3.7 & 4406 & 1186 \\
\hline Rosa spp. & - & 0.01 & 0.01 & 1.0 & 1.0 & 156 & 156 & 0.00 & 0.00 & 0.0 & 0.0 & 0 & 0 & 0.04 & 0.03 & 2.8 & 2.4 & 1031 & 881 \\
\hline Rubus spp. & - & 0.10 & 0.06 & 6.5 & 3.7 & 1938 & 1224 & 0.11 & 0.05 & 16.0 & 7.3 & 1156 & 558 & 0.39 & 0.08 & 21.7 & 5.6 & 4969 & 1393 \\
\hline $\begin{array}{l}\text { Sambucus } \\
\text { canadensis }\end{array}$ & FAC & 0.01 & 0.01 & 0.4 & 0.4 & 31 & 31 & 0.00 & 0.00 & 0.0 & 0.0 & 0 & 0 & 0.08 & 0.03 & 2.2 & 1.0 & 281 & 160 \\
\hline $\begin{array}{l}\text { Symphoricarpos } \\
\text { orbiculatus }\end{array}$ & FACU & 0.01 & 0.01 & 0.9 & 0.9 & 31 & 31 & 0.00 & 0.00 & 0.0 & 0.0 & 0 & 0 & 0.01 & 0.01 & 0.2 & 0.2 & 31 & 31 \\
\hline $\begin{array}{l}\text { Euonymus } \\
\text { alatus }\end{array}$ & NI & 0.00 & 0.00 & 0.0 & 0.0 & 0 & 0 & 0.00 & 0.00 & 0.0 & 0.0 & 0 & 0 & 0.03 & 0.02 & 1.3 & 0.9 & 313 & 233 \\
\hline $\begin{array}{l}\text { Euonymus } \\
\text { americanus }\end{array}$ & FAC & 0.00 & 0.00 & 0.0 & 0.0 & 0 & 0 & 0.00 & 0.00 & 0.0 & 0.0 & 0 & 0 & 0.01 & 0.01 & 0.4 & 0.4 & 94 & 94 \\
\hline $\begin{array}{l}\text { Lindera } \\
\text { benzoin }\end{array}$ & FAC & 0.00 & 0.00 & 0.0 & 0.0 & 0 & 0 & 0.00 & 0.00 & 0.0 & 0.0 & 0 & 0 & 0.71 & 0.08 & 41.8 & 5.3 & 11844 & 2271 \\
\hline Prunus sp. & - & 0.00 & 0.00 & 0.0 & 0.0 & 0 & 0 & 0.00 & 0.00 & 0.0 & 0.0 & 0 & 0 & 0.01 & 0.01 & 0.4 & 0.4 & 31 & 31 \\
\hline Unidentified & & 0.00 & 0.00 & 0.0 & 0.0 & 0 & 0 & 0.00 & 0.00 & 0.0 & 0.0 & 0 & 0 & 0.04 & 0.02 & 2.2 & 1.3 & 344 & 210 \\
\hline & SUM & & & 68.4 & & 9375 & & & & 80.0 & & 9375 & & & & 95.0 & & 24375 & \\
\hline
\end{tabular}


Table 2-10. Vine abundance summaries by research site. Abundance data are given as mean frequency, percent cover, and IV $( \pm \mathrm{SE})$ at each site. Species are sorted alphabetically by name. WIS = Wetland Indicator Status (see Appendix Table 16 for categories). Values in bold show the species with the highest IV and percent cover at each site.

\begin{tabular}{|c|c|c|c|c|c|c|c|c|c|c|c|c|c|c|c|c|c|c|c|}
\hline \multirow[b]{2}{*}{ Species } & \multirow[b]{2}{*}{ WIS } & \multicolumn{6}{|c|}{ Site 3: Wet Site } & \multicolumn{6}{|c|}{ Site 2: Intermediate Site } & \multicolumn{6}{|c|}{ Site 1: Dry Site } \\
\hline & & Freq. & $\begin{array}{l}\text { Std. } \\
\text { Error }\end{array}$ & $\begin{array}{c}\% \\
\text { Cover }\end{array}$ & $\begin{array}{l}\text { Std. } \\
\text { Error }\end{array}$ & IV & $\begin{array}{l}\text { Std. } \\
\text { Error }\end{array}$ & Freq. & $\begin{array}{l}\text { Std. } \\
\text { Error }\end{array}$ & $\begin{array}{c}\% \\
\text { Cover }\end{array}$ & $\begin{array}{l}\text { Std. } \\
\text { Error }\end{array}$ & IV & $\begin{array}{l}\text { Std. } \\
\text { Error }\end{array}$ & Freq. & $\begin{array}{l}\text { Std. } \\
\text { Error }\end{array}$ & $\begin{array}{c}\% \\
\text { Cover }\end{array}$ & $\begin{array}{l}\text { Std. } \\
\text { Error }\end{array}$ & IV & $\begin{array}{l}\text { Std. } \\
\text { Error }\end{array}$ \\
\hline $\begin{array}{l}\text { Campsis } \\
\text { radicans }\end{array}$ & FAC & 0.28 & 0.08 & 3.3 & 1.3 & 22.5 & 7.8 & 0.21 & 0.07 & 1.3 & 0.6 & 7.5 & 3.4 & 0.15 & 0.06 & 1.0 & 0.6 & 3.9 & 1.5 \\
\hline $\begin{array}{l}\text { Euonymus } \\
\text { fortunei }\end{array}$ & NI & 0.01 & 0.01 & 0.0 & 0.0 & 0.5 & 0.5 & 0.03 & 0.03 & 0.5 & 0.5 & 0.9 & 0.9 & 0.11 & 0.06 & 3.6 & 3.2 & 3.5 & 2.4 \\
\hline $\begin{array}{l}\text { Lonicera } \\
\text { japonica }\end{array}$ & NI & 0.23 & 0.07 & 3.4 & 2.0 & 10.5 & 3.5 & 0.31 & 0.08 & 5.5 & 2.7 & 8.4 & 2.3 & 0.79 & 0.07 & 19.6 & 3.7 & 37.9 & 4.2 \\
\hline $\begin{array}{c}\text { Menispermum } \\
\text { canadensis }\end{array}$ & FACU & 0.00 & 0.00 & 0.0 & 0.0 & 0.0 & 0.0 & 0.03 & 0.03 & 0.2 & 0.2 & 0.5 & 0.5 & 0.09 & 0.04 & 0.4 & 0.2 & 2.4 & 1.3 \\
\hline $\begin{array}{l}\text { Parthenocissus } \\
\text { quinquifolia }\end{array}$ & FACU & 0.16 & 0.06 & 0.6 & 0.2 & 5.6 & 2.2 & 0.31 & 0.09 & 4.5 & 2.1 & 9.3 & 2.6 & 0.46 & 0.09 & 1.3 & 0.3 & 9.9 & 2.4 \\
\hline Smilax spp. & - & 0.01 & 0.01 & 0.0 & 0.0 & 0.2 & 0.2 & 0.03 & 0.02 & 0.1 & 0.0 & 0.8 & 0.6 & 0.28 & 0.05 & 2.0 & 0.9 & 8.4 & 1.9 \\
\hline $\begin{array}{l}\text { Toxicodendron } \\
\text { radicans }\end{array}$ & FAC & 0.59 & 0.09 & 15.9 & 5.0 & 49.0 & 7.5 & 0.83 & 0.06 & 40.9 & 6.6 & 57.5 & 5.5 & 0.65 & 0.07 & 9.4 & 3.1 & 26.1 & 4.6 \\
\hline Vitaceae & - & 0.08 & 0.03 & 0.2 & 0.1 & 6.7 & 5.0 & 0.26 & 0.06 & 1.6 & 0.9 & 10.1 & 3.1 & 0.28 & 0.06 & 2.2 & 0.9 & 7.9 & 2.1 \\
\hline TOTAL & & 1.35 & & 23.59 & & 95.00 & & 2.00 & & 54.53 & & 95.00 & & 2.80 & & 39.47 & & 100.00 & \\
\hline
\end{tabular}


Table 2-11. Summary of species, environmental variables and biotic variables associated with axes from NMS ordination of woody vegetation at all sites. Species having the highest negative and positive $r^{2}$ values with each axis are shown. Environmental and biotic variables with $\mathrm{r}^{2} \geq 0.15$ for each axis are shown. The + or - indicates the direction of the correlation.

\begin{tabular}{|c|c|c|c|c|c|c|c|c|c|c|}
\hline & $\begin{array}{c}\% \\
\text { Variance } \\
\text { Explained }\end{array}$ & Species & $\mathrm{r}$ & $r^{2}$ & $\begin{array}{c}\text { Environmental } \\
\text { Variable }\end{array}$ & $\mathrm{r}$ & $r^{2}$ & $\begin{array}{c}\text { Biotic } \\
\text { Variable }\end{array}$ & $r$ & $r^{2}$ \\
\hline \multirow[t]{4}{*}{$\begin{array}{c}\text { Axis } \\
1\end{array}$} & \multirow[t]{4}{*}{$34.50 \%$} & $\begin{array}{l}\text { (-) Lindera } \\
\text { benzoin }\end{array}$ & -0.765 & 0.586 & \multirow[t]{4}{*}{ (+) Days Flooded } & \multirow[t]{4}{*}{0.613} & \multirow[t]{4}{*}{0.376} & $\begin{array}{c}\text { (-) Exotic Vine } \\
\text { IV }\end{array}$ & -0.665 & 0.442 \\
\hline & & $\begin{array}{l}\text { (+) Cornus } \\
\text { foemina }\end{array}$ & 0.585 & 0.342 & & & & (-) Shrub Density & -0.432 & 0.187 \\
\hline & & & & & & & & $\begin{array}{l}\text { (+) FACW/OBL } \\
\text { Shrub IV }\end{array}$ & 0.634 & 0.402 \\
\hline & & & & & & & & $\begin{array}{c}(+) \% \text { Herb } \\
\text { Cover }\end{array}$ & 0.582 & 0.339 \\
\hline \multirow[t]{2}{*}{$\begin{array}{c}\text { Axis } \\
2\end{array}$} & $18.50 \%$ & $\begin{array}{l}\text { (+) Lonicera } \\
\text { maackii }\end{array}$ & 0.674 & 0.454 & \multirow[t]{2}{*}{-} & & & $\begin{array}{l}\text { (+) Exotic Shrub } \\
\text { IV }\end{array}$ & 0.668 & 0.447 \\
\hline & & $\begin{array}{c}\text { (-) Fraxinus } \\
\text { pennsylvanica } \\
\text { (saplings) }\end{array}$ & -0.498 & 0.248 & & & & $\begin{array}{c}(+) \% \text { Vine } \\
\text { Cover }\end{array}$ & 0.453 & 0.205 \\
\hline \multirow[t]{2}{*}{$\begin{array}{c}\text { Axis } \\
3\end{array}$} & $19.20 \%$ & $\begin{array}{c}\text { (+) Celtis } \\
\text { laevigata } \\
\text { (seedlings) }\end{array}$ & 0.446 & 0.199 & \multirow[t]{2}{*}{$\begin{array}{l}\text { (+) Distance } \\
\text { From Edge }\end{array}$} & \multirow[t]{2}{*}{0.45} & \multirow[t]{2}{*}{0.203} & $\begin{array}{c}\text { (+) Seedling } \\
\text { Density }\end{array}$ & \multirow[t]{2}{*}{0.443} & \multirow[t]{2}{*}{0.196} \\
\hline & & (-) Rubus spp. & -0.629 & 0.395 & & & & & & \\
\hline
\end{tabular}


Table 2-12. Pearson correlation coefficients, $r^{2}$, and $p$-values for relationships between number of flooded days and shrub stem density by total stem density and density of individual species. Data includes 55 transects from all three sites where the number of flooded days was estimated.

\begin{tabular}{ccccc}
\hline \hline Species & $\mathrm{n}$ & $\mathrm{r}$ & $\mathrm{r}^{2}$ & $\mathrm{p}$-value \\
\hline $\begin{array}{c}\text { Total Stems } \\
\text { Cornus } \\
\text { foemina } \\
\begin{array}{c}\text { Lindera } \\
\text { benzoin }\end{array}\end{array}$ & 55 & -0.12 & 0.01 & 0.3737 \\
$\begin{array}{c}\text { Lonicera } \\
\text { maackii }\end{array}$ & 55 & 0.36 & 0.13 & 0.0072 \\
\begin{tabular}{c} 
Rubus sp. \\
\hline \hline
\end{tabular} & 55 & -0.34 & 0.12 & 0.0107 \\
\hline
\end{tabular}




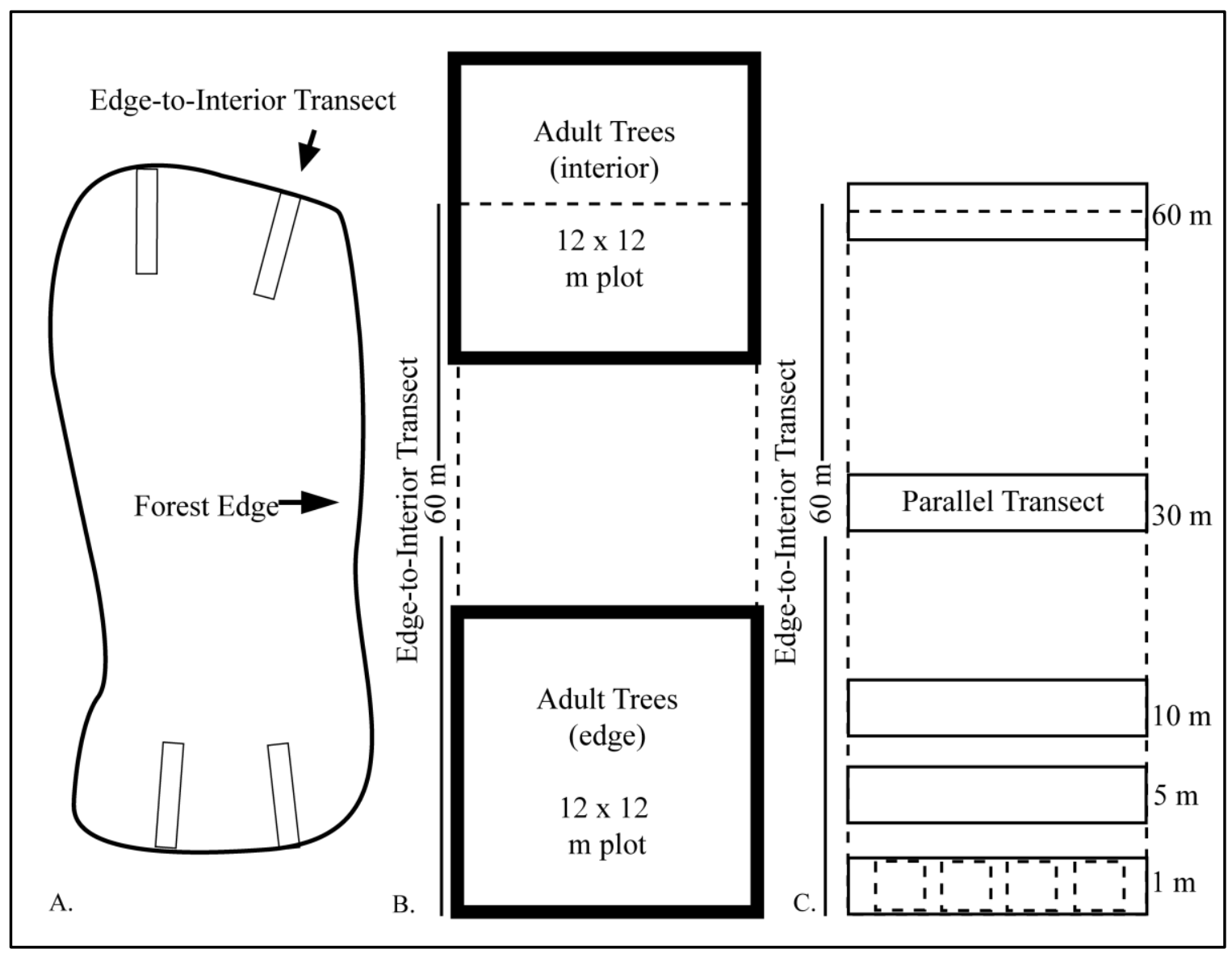

Figure 2-1. Layout and dimensions of sampling units. A. An outline of an irregularly shaped forest patch with a hypothetical placement of edge-to-interior transects. B. An edge-to-interior transect (large dashed rectangle), with the placement of adult tree sampling plots. C. An edge-to-interior transect containing five 12 x $2 \mathrm{~m}$ parallel transects at 1, 5, 10, 30 and $60 \mathrm{~m}$ from the forest edge. Parallel transects contained four 2 $\mathrm{x} 2 \mathrm{~m}$ quadrats for collecting plant, ground cover and elevation data. B and $\mathrm{C}$ both depict the same edge-to-interior transect, but featuring different sampling areas. 


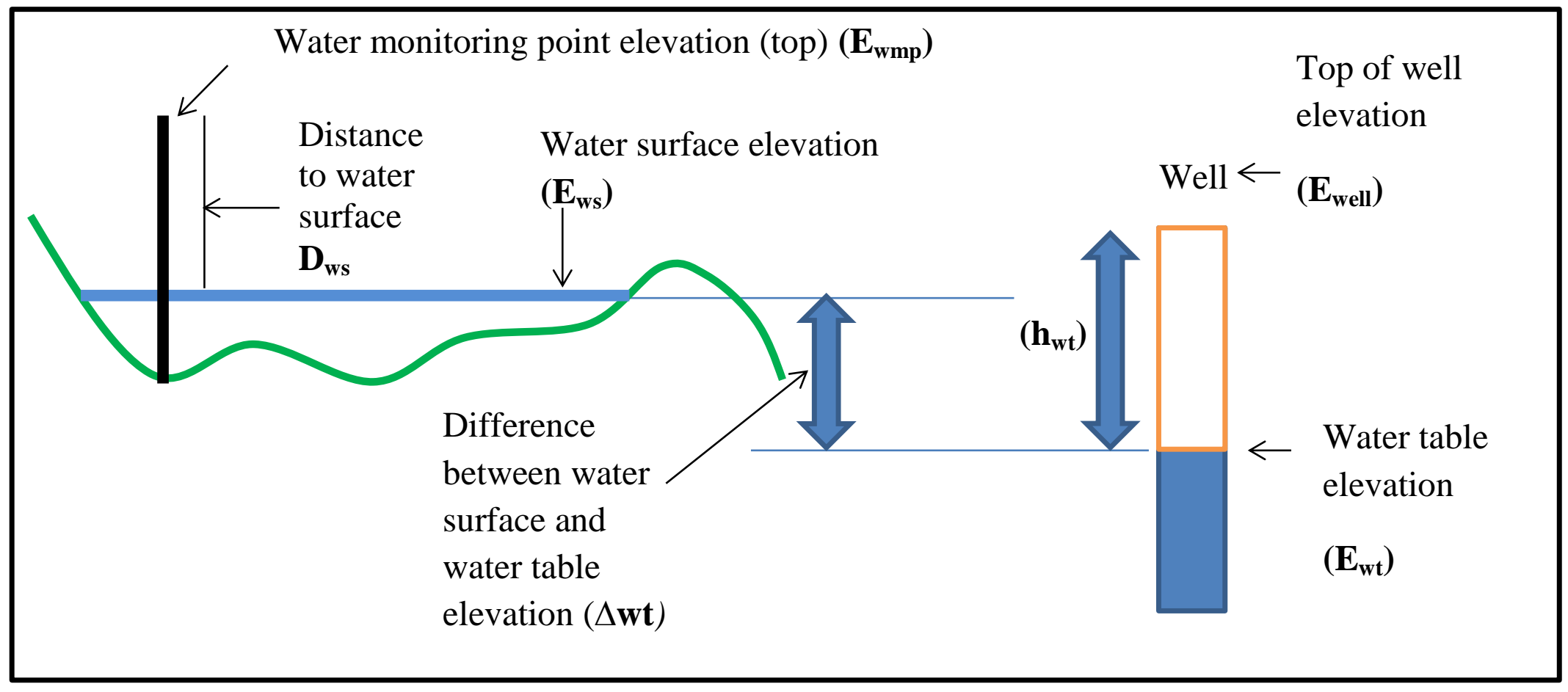

Figure 2-2. Visual aid explaining terms used in quantifying site hydrology. Definitions of terms used are: $\mathrm{E}_{\mathrm{wmp}}$ is the elevation of the top of the water monitoring point, $\mathrm{E}_{\mathrm{ws}}=$ elevation of the water surface, $\mathrm{E}_{\mathrm{wt}}=$ elevation of the water table, $\Delta \mathrm{wt}=$ distance between the water surface elevation and the water table elevation, $\mathrm{E}_{\mathrm{well}}$ is the elevation of the top of the groundwater monitoring well, $\mathrm{D}_{\mathrm{ws}}$ distance between water surface and top of water monitoring point, and $\mathrm{h}_{\mathrm{wt}}=$ difference between the elevation of the water table and the top of the well. 


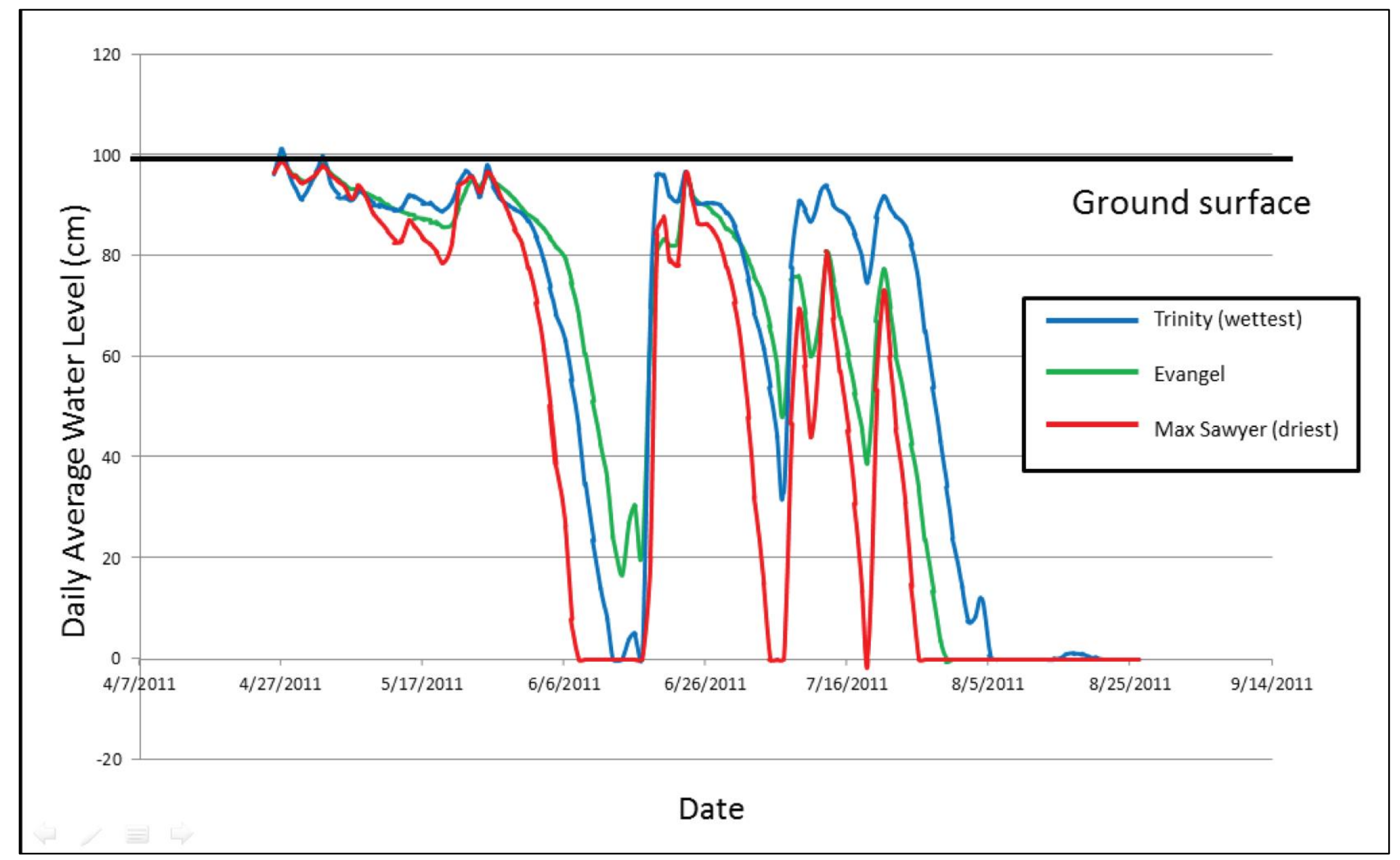

Figure 2-3. Hydrographs depicting water levels in water monitoring wells in each of the 3 research sites, relative to the ground surface $(100 \mathrm{~cm})$. 


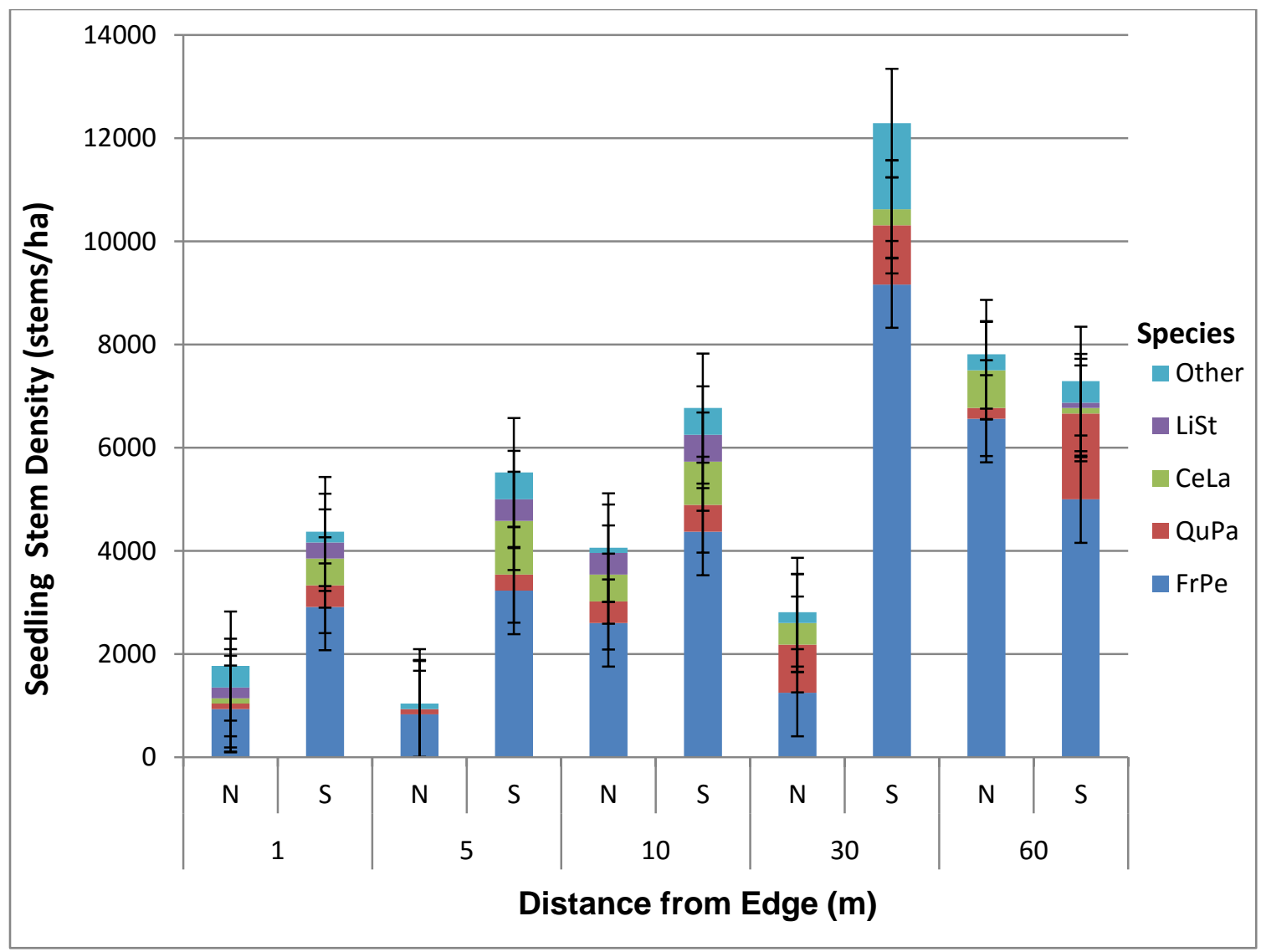

Figure 2-4. Seedling density in north and south-facing edges at varying distance from the edge. Bars are color coded (see legend) to show density of the most abundant species. Species shown are Fraxinus pennsylvanica (FrPe), Quercus palustris (QuPa), Celtis laevigata (CeLa) and Liquidambar styraciflua (LiSt). The density of all other tree seedlings combined is included in the "Other" category. 


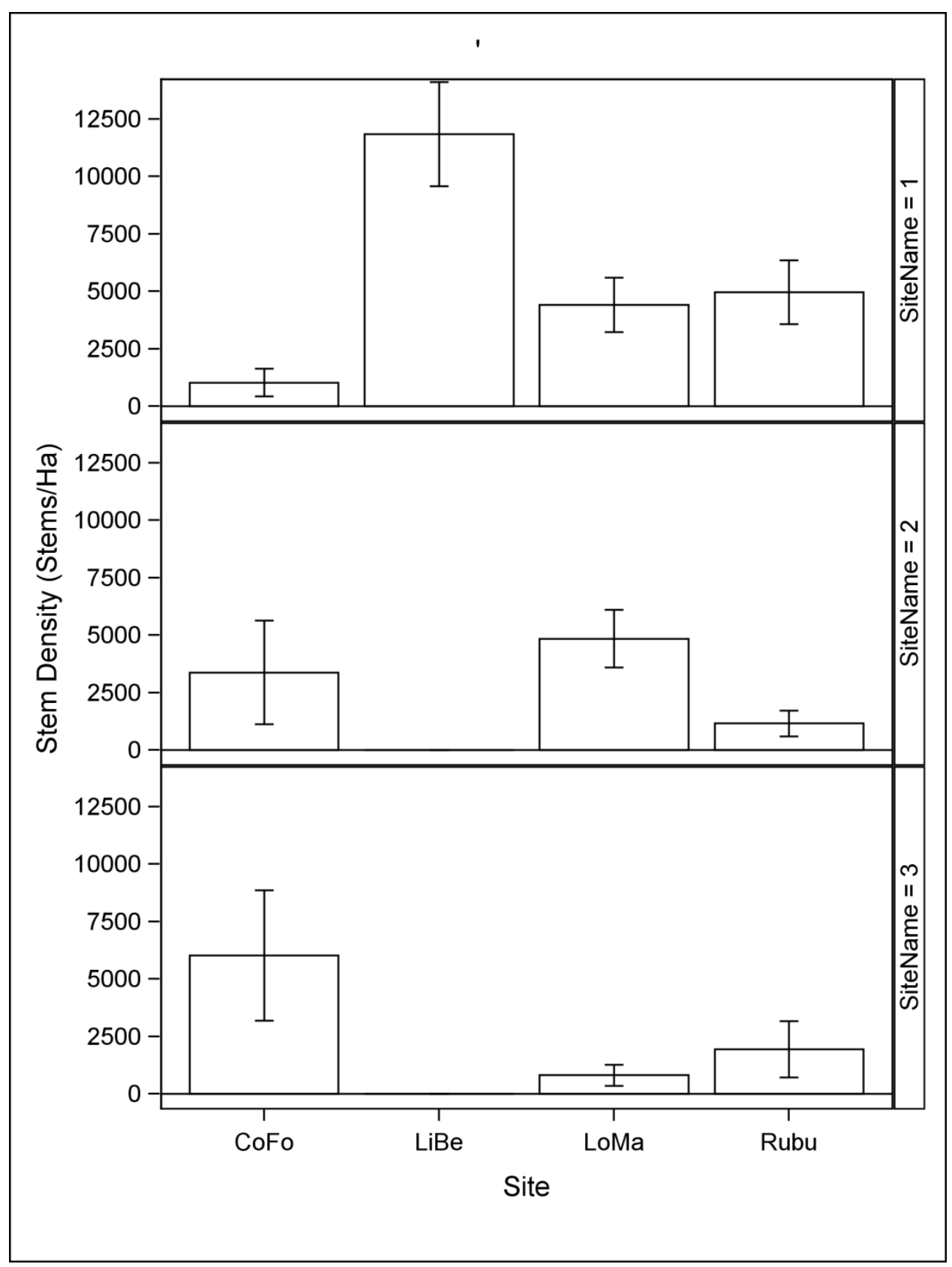

Figure 2-5. Mean stem density of four shrub species at each site. Mean values were calculated by pooling shrub data from all parallel transects $(n=20)$ within each site. Species codes are: $\mathrm{CoFo}=$ Cornus foemina $(\mathrm{FACW}), \mathrm{LiBe}=$ Lindera benzoin $(\mathrm{FAC})$, LoMa=Lonicera maackii, Rubu=Rubus spp. Sites 1, 2 and 3 are the dry, intermediate and wet sites, respectively. Error bars are \pm 1 SE. 


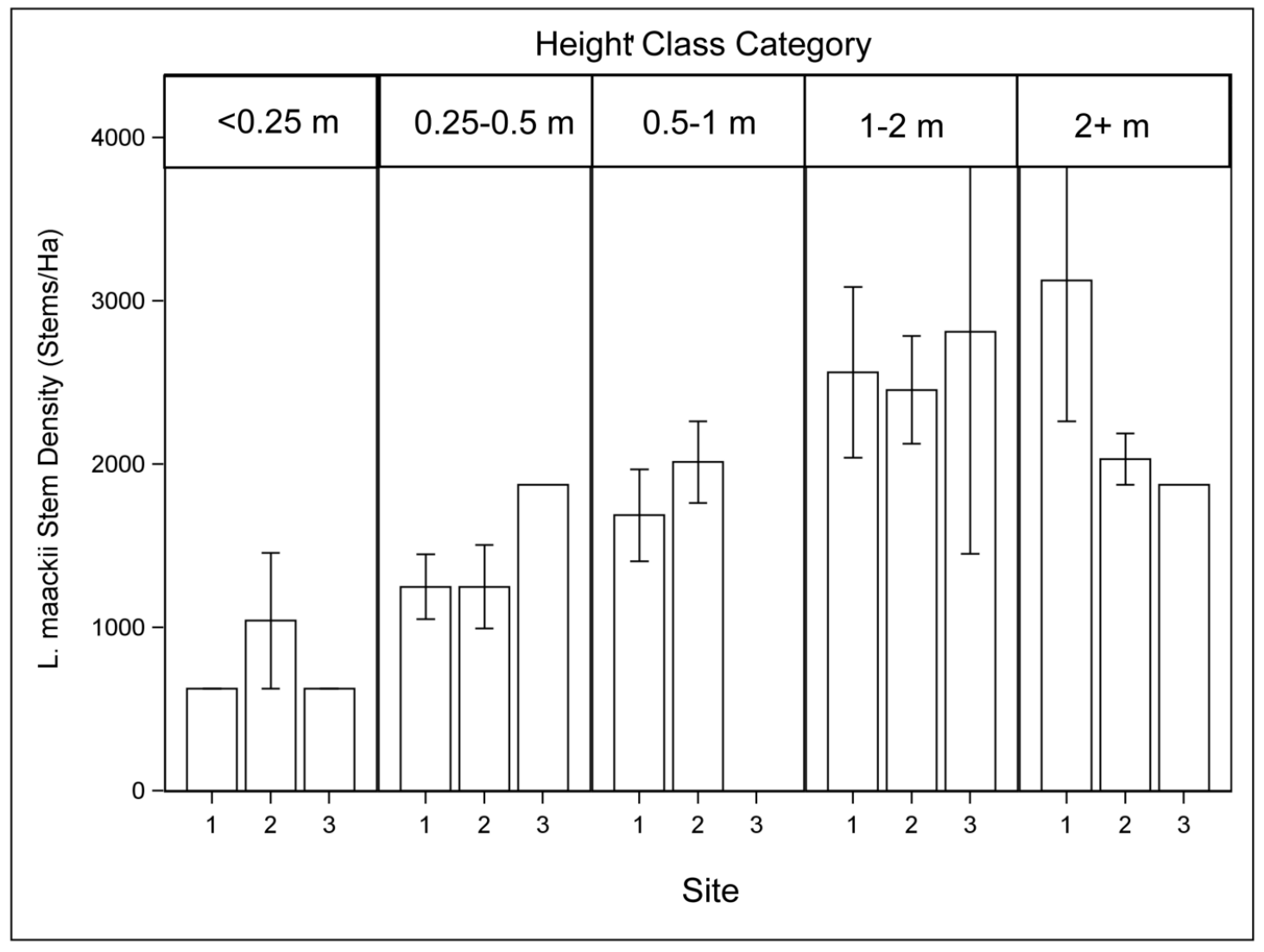

Figure 2-6. Density of Lonicera maackii stems in different height class categories at each site. Site $1=$ dry site, Site 2 = intermediate site, and Site $3=$ wet site. Error bars are \pm 1 SE. 


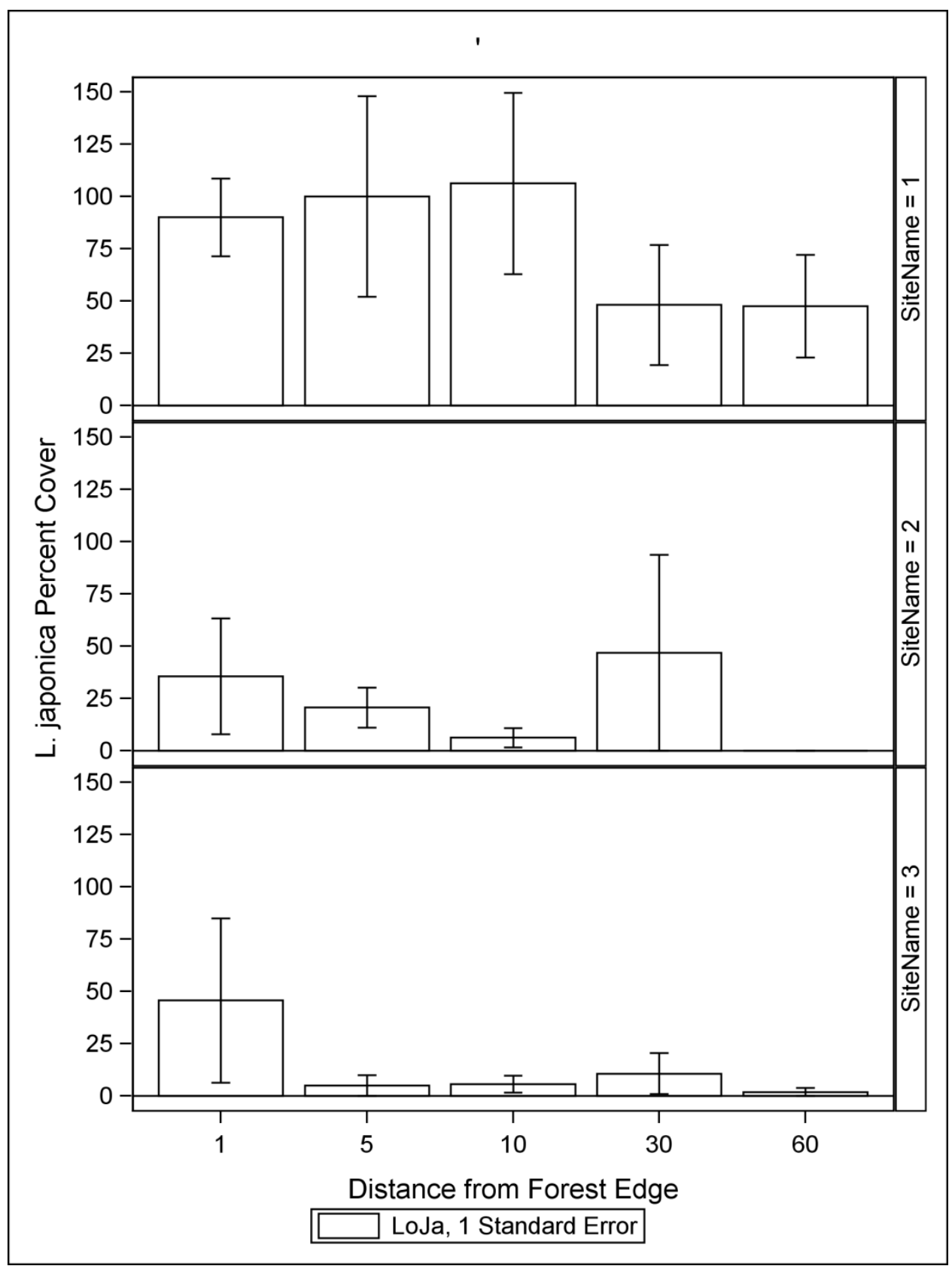

Figure 2-7. Total percent cover of Lonicera japonica vines with distance from the forest edge at all three research sites. Each bar represents the mean percent cover of L. japonica at four transects per site, corresponding to 1, 5, 10, 30 or 60 meters from the forest edge. Sites 1, 2 and 3 refer to the dry, intermediate, and wet sites, respectively. Error bars are $\pm 1 \mathrm{SE}$. 


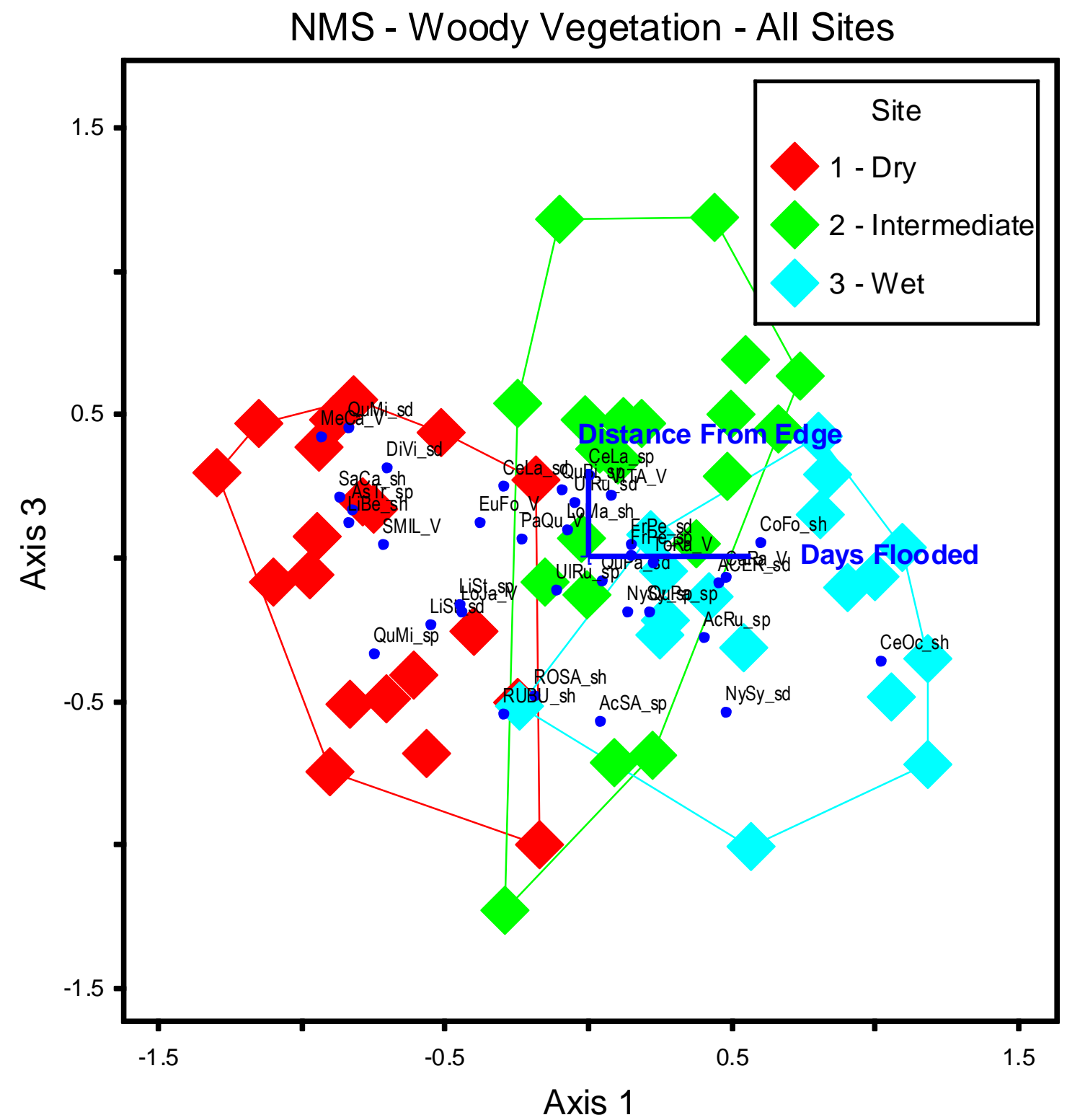

Figure 2-8. Biplot of NMS ordination based on woody plant species Importance Values (IVs) in all sampling units (parallel transects) from all three study sites. Environmental variables most strongly correlated with either axis $\left(r^{2}\right.$ values of 0.15 or greater) are depicted in dark blue lines and letters; dark blue lines indicate the positive direction of the correlation. Axis 1 and 3 explained $34.5 \%$ and $19.2 \%$ of the variation in the IV matrix, respectively. IVs were computed separately for seedlings and saplings, and therefore are displayed as different "species" in the ordination plot. Vegetation layers are coded as follows: $\mathrm{sh}=$ shrub, $\mathrm{V}=$ vine, $\mathrm{sp}=$ sapling, $\mathrm{sd}=$ tree seedling. Abbreviations for species are given in Appendix Table 2. 


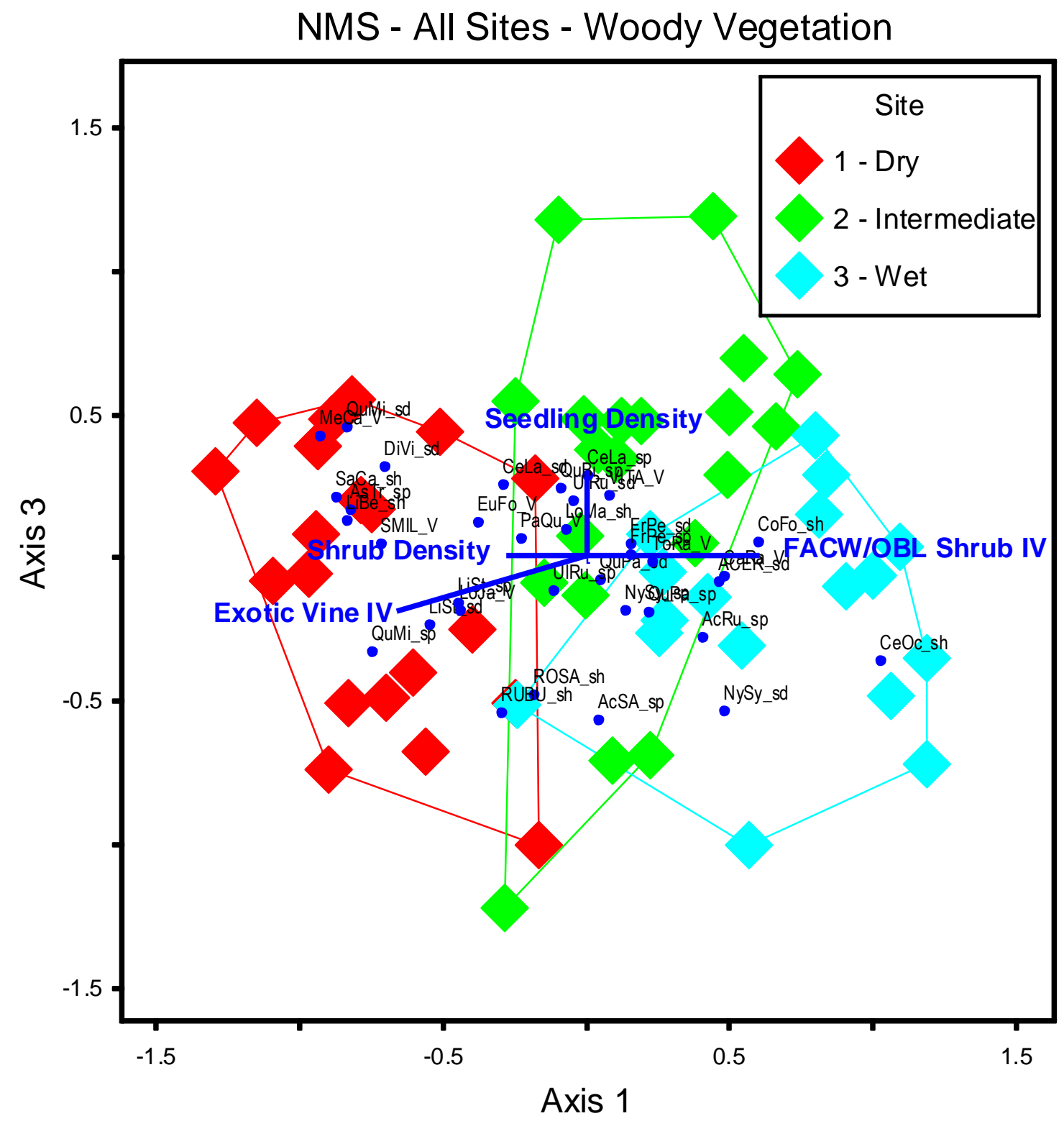

Figure 2-9. Biplot of NMS ordination based on woody plant species IVs in all sampling units (parallel transects) from all three study sites. Biotic variables most strongly correlated with either axis $\left(\mathrm{r}^{2}\right.$ values of 0.15 or greater) are depicted in dark blue; dark blue lines indicate the positive direction of the correlation. Axis 1 and 3 explained $34.5 \%$ and $19.2 \%$ of variation in the IV matrix, respectively. IVs were computed separately for seedlings and saplings, and therefore are displayed as different "species" in the ordination plot. Vegetation layers are coded as follows: $s h=$ shrub, $V=$ vine, $s p=s a p l i n g, ~ s d=t r e e$ seedling. Abbreviations for species are given in Appendix Table 2. 


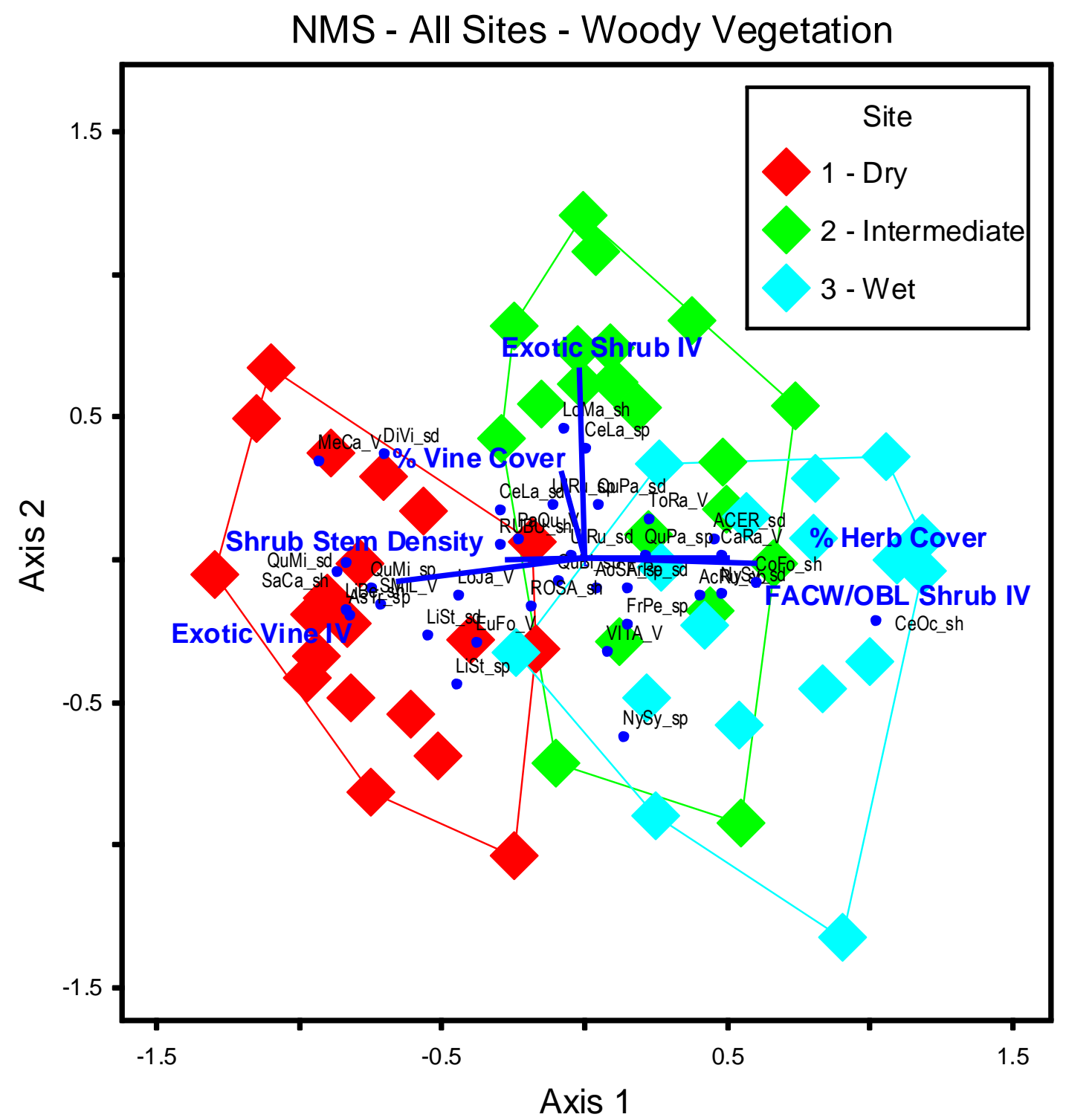

Figure 2-10. Biplot of NMS ordination based on woody plant species IVs in all sampling units (parallel transects) from all three study sites. Biotic summary variables most strongly correlated with either axis $\left(\mathrm{r}^{2}\right.$ values of 0.15 or greater) are depicted in dark blue; dark blue lines indicate the direction of the correlation. Axis 1 and 2 explained $34.5 \%$ and $18.5 \%$ of variation in the IV matrix, respectively. IVs were computed separately for seedlings and saplings, and therefore are displayed as different "species" in the ordination plot. Vegetation layers are coded as follows: $s h=$ shrub, $V=$ vine, $p=$ sapling, $s d=$ tree seedling. Abbreviations for species are given in Appendix Table 2. 


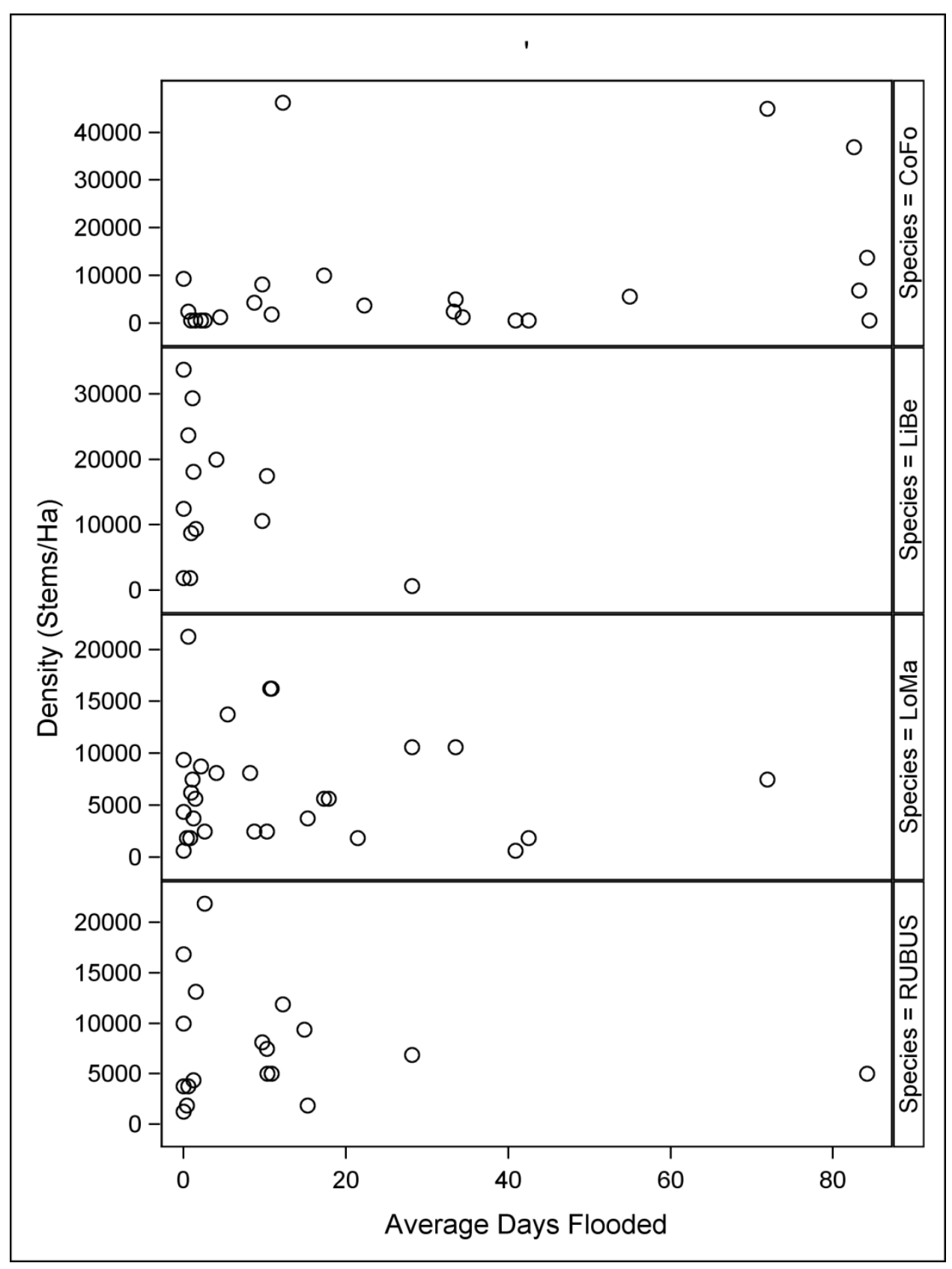

Figure 2-11. Stem density of four dominant shrub species as it relates to the number of days flooded in transects. $\mathrm{CoFo}=$ Cornus foemina $(\mathrm{FACW}), \mathrm{LoMa}=$ Lonicera maackii, Rubus=Rubus spp., LiBe=Lindera benzoin $(\mathrm{FAC})$. 


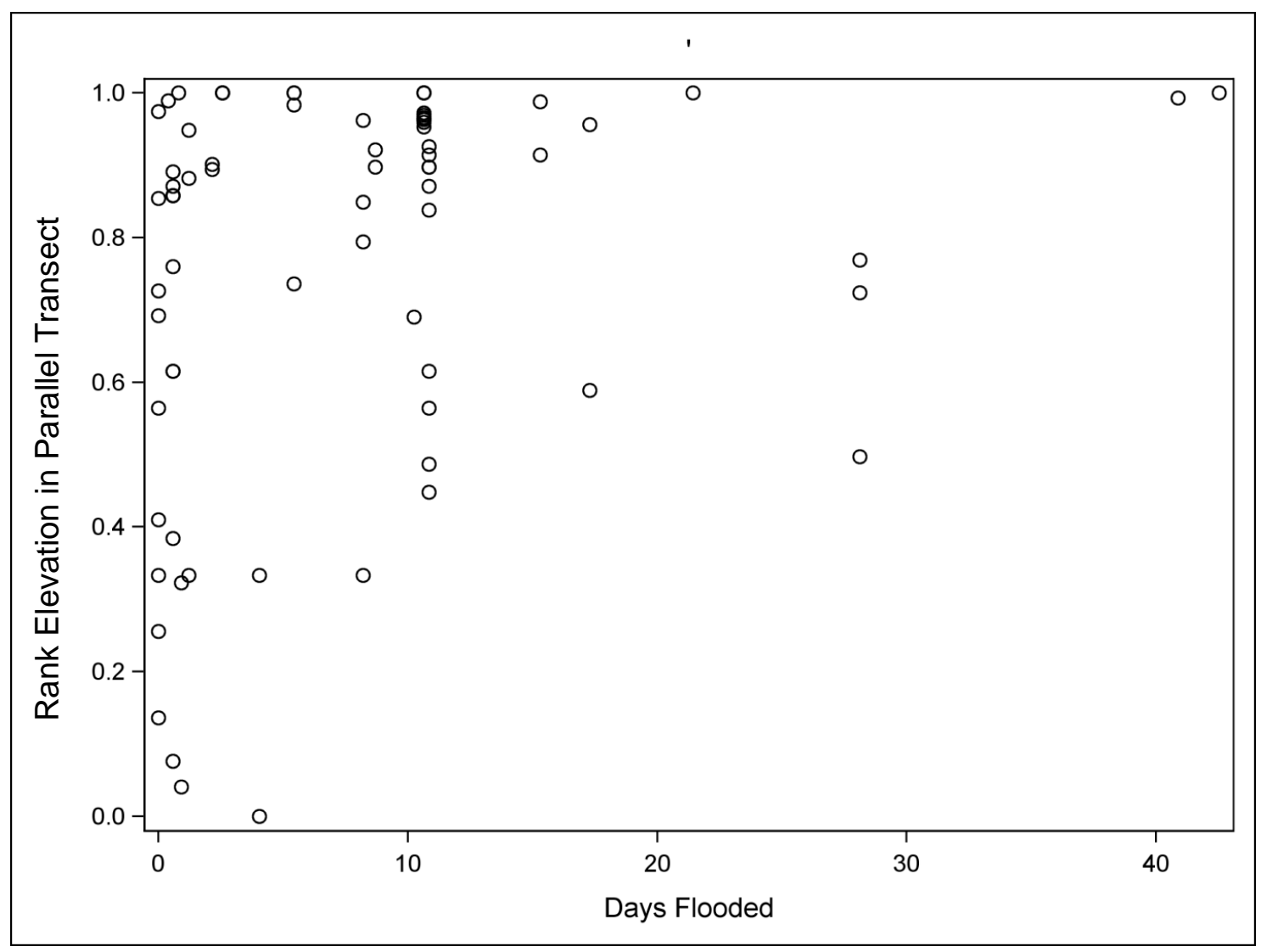

Figure 2-12. Factor - ceiling distribution of the number of days flooded vs. the rank elevation (a measure of the relative elevation of plants in a transect) of all Lonicera maackii individuals sampled. Each point represents an individual plant. Data across all sites is shown. The distribution reveals that L. maackii was restricted to increasingly higher elevation microsites within transects as days flooded per year increased 


\section{CHAPTER III}

\section{EFFECTS OF FLOODING DURATION, FLOODING DEPTH AND LIGHT ON THE GROWTH AND SURVIVAL OF LONICERA MAACKII IN AN EXPERIMENTAL MESOCOSM}

\section{$\underline{\text { Introduction }}$}

The success of invasive species has been described as being dependent on the match between "opportunity and opportunist" (Zedler and Kercher 2004), in which opportunities are determined by particular disturbance patterns. Wetland hydrology - the frequency, timing, depth and duration of water level fluctuations in a wetland-may create opportunities, or barriers, for the establishment of invasive plant species, depending on plant life history traits. Gradients of flood duration and flood depth are the most important factors limiting the distribution of individual species in bottomland hardwood forests (Kozlowski 2002). Therefore, forested wetlands are dominated by woody vegetation that has physiologically evolved to withstand the anaerobic conditions associated with water-logged wetland soils, either through tolerance or avoidance of stress (Mitsch 2000). However, even hydrophytic woody species are impeded by floodrelated stresses at early life history stage, and successful establishment of woody seedlings depends largely on the availability of unflooded soil. 
Such "safe sites" are created due to both wetland drawdown and variations in wetland microtopography. Microtopography interacts with wetland hydrology to create spatial and temporal heterogeneity in inundation patterns, increasing the diversity of wetland microsites, and providing refugia for the colonization of plant species with different requirements and physiological limitations. Thus, since microtopography expands the range of available regeneration niches (sensu Harper 1966), certain plant invaders may be able to colonize both upland and wetland ecosystems.

The same disturbances that create microtopography may be accompanied by changes in light availability. For instance, natural tree fall creates tip-up mounds accompanied by canopy gaps and logged wetland forests undergo dramatic changes in microtopography due to heavy equipment operations (Anderson et al. 2007). Thus, a number of studies have examined the interaction between light availability and microtopography on various measures of plant success and plant community composition and structure (Battaglia et al. 2000).

In this chapter, I examine the potential of wetland microtopography and light availability to impact the growth and survival of Lonicera maackii seedlings. The extent and impact of Lonicera spp. invasion in North American forests is a growing concern that has received considerable attention in recent years. L. maackii, in particular, has been cited as an invader of serious concern, with the potential to reduce species diversity (Hartman \& McCarthy, 2008) and limit recruitment of native species (Ens \& French, 2008). In its native range, this exotic shrub occupies riparian habitat, which may be thought of as lying somewhere between the wetland and upland continuum. Studies concerning this species in eastern North America have largely been restricted to upland 
forests, but several recent papers have studied its occurrence in bottomland hardwood forests (Predick and Turner 2008, Swab et al. 2008, Mills et al. 2009, Pennington et al. 2010, Boyce et al. 2012). However, it appears to be less successful in bottomland than upland habitats (Gayek and Quigley 2001). Abiotic factors that are likely to be important in facilitating or restricting the recruitment and success of L. maackii in wetland forests include inundation duration, water depth, and light levels.

The importance of light availability to L. maackii has been implicated in a number of studies. Studies from upland forest systems indicate that successful invasion of Lonicera maackii is associated with high light microhabitats such as forest edges and canopy gaps (Luken and Goessling 1995, Luken et al. 1995, Hutchinson and Vankat 1997). Its success may be due, in part, to its ability to take advantage of light-creating disturbances to a greater degree than native shrub species (Luken et al. 1997). Hidayati et al. (2000) demonstrated that higher percentages of L. maackii germinated in light than dark treatments, though the effects of partial shade were not examined. But despite being fairly shade intolerant (Luken et al. 1995), it has an extended leaf phenology that allows it to persist in the forest understory after canopy closure (McEwan et al. 2009).

In contrast to light requirements and tolerances, little appears to be known about the flood tolerance of $L$. maackii —a factor which most certainly restricts its potential habitat within wetland areas. The wetland indicator status of $L$. maackii has not been evaluated for its introduced range (NRCS 2016). However, in its native range, L. maackii occupies riparian habitat, which may be thought of as lying somewhere between the wetland and upland continuum. Two studies (Gayek and Quigley 2001, Swab et al. 2008) suggest a relationship between elevation and abundance of this woody, invasive 
shrub L. maackii. According to both papers, which examined the distributional patterns of honeysuckle along upland-bottomland elevation gradients in Ohio, USA, L. maackii is less successful at low elevations. This was anecdotally attributed to a dense herbaceous understory in Gayek and Quigley (2001), which was thought to be a potential limitation to Lonicera sp. recruitment. However, Swab et al. (2008) did not identify dense herbaceous layers in their bottomland areas, and excluded competition with herbaceous vegetation in their bottomland areas as a possible driving mechanism for limited Lonicera sp. Recruitment there, and hydrology was proposed as the most probable driving factor for these observed trends. These studies strongly imply that flooding limits L. maackii germination, growth and/or survival.

The aforementioned studies suggest that wetland hydrology influences the distributional patterns of Lonicera maackii, but to my knowledge no published studies have used controlled experiments to determine the flood tolerance threshold for $L$. maackii. The importance of light availability on the success and distribution of $L$. maackii is better documented. However, no studies to my knowledge, have simultaneously attempted understand the combined main effects (and any interaction) of flooding and high vs. low light environments on any measure of $L$. maackii success. In this study, I manipulated light availability, flooding duration, and flooding depth in a fully crossed mesocosm experiment with the following goals: 1) to determine the main effects of light and flooding treatment variables on the growth and survival of L. maackii seedlings, 2) to identify any significant interactions between light, flooding depth and flooding duration treatments, and 3) to identify thresholds of flooding that appear to severely impede the growth and survival of L. maackii. 


\section{Methods}

\section{Experimental Design}

We examined the effects of light and flooding characteristics expected to affect the growth and survival of L. maackii seedlings using a split-split plot design. The three manipulated, explanatory variables were: simulated canopy closure (2 levels), flooding depth (4 levels) and flooding duration (3 levels). Levels of explanatory variables at the plot, split-plot and split-split plot level are summarized in Fig. 3-1. Response variables were: change in plant height, change in leaf number, aboveground biomass (ABG), belowground biomass (BGB), root-shoot ratio (RSR) and days survived (see Experimental Timelines and Protocols).

\section{Plant materials, selection and maintenance}

First year seedlings were obtained from a naturalized population of L. maackii in a mesic upland forest (Cherokee Park) in Louisville, Kentucky. Seedlings were identified as such by presence of cotyledons or lack of woody stem tissue. The risk of accidentally collecting non-target species was minimized by ensuring that no other Lonicera species were present in the collection area. Seedlings of similar size $(\sim 3-6 \mathrm{~cm})$ were transplanted into small peat pots using a common soilless potting mix (Fafard® Complete Potting Mix with slow-release fertilizer), and allowed to acclimate to their containers for approximately two weeks in an outdoor setting (part-sun/part-shade). At this point, seedlings were transplanted into larger plastic pots $(9 \mathrm{~cm}$ by $9 \mathrm{~cm}$ by $13 \mathrm{~cm}$ depth) with a mix of 6 parts field soil to 1 part peat moss. The field soil was obtained from a nearby stand of bottomland hardwood forest in southwest Jefferson County, Kentucky, from the 
Zipp soil map unit, which is characterized as a poorly drained silty clay loam (NRCS 2005). Seedlings were allowed to acclimate for an additional two weeks in the larger containers before the start of the experiment.

Size differences in seedlings were apparent after this acclimation period. In order to minimize the risk of confounding initial seedling height with experimental treatments, the following measures were taken. The initial height (one day prior to the beginning of the experiment) of each seedling was determined by measuring from the stem base to the apical meristem. Seedlings with signs of disease or extensive insect damage were discarded. The largest 144 seedlings (ranging from 10.1-21.2 cm in height) were sorted into six height classes with equal numbers of seedlings.

Each of the 24 treatment groups (2 light levels x 4 flood depth levels x 3 flood duration treatments $=24$ treatment groups) was assigned one seedling from each of the 6 height classes $(24$ treatment groups $\times 6$ seedlings $=144$ seedlings $)$. The six seedlings in each of the 24 treatment groups was randomly assigned to one of 6 experimental tanks. Thus each experimental tank received one seedling from each treatment group (6 tanks $\mathrm{x}$ 24 treatment groups=144 seedlings), and initial seedling size did not differ significantly among treatment groups or blocks.

\section{Experimental timeline and protocols}

Each of the six experimental units consisted of a single plastic tank measuring 70 x 45 x $20 \mathrm{~cm}$ ( $~ 63$ L capacity). Tanks were arranged in a single row on top of a leveled wood riser (Fig. 3-2A) and filled with water to a depth of approximately $15 \mathrm{~cm}$ from the city water supply, a height sufficient to achieve the intended flooding depths. Overflow 
holes were drilled just above this to prevent overfilling. To prevent a water temperature gradient from forming on different sides of the tank, a small submersible pump was placed centrally in each tank to circulate water. Each half of the tank was assigned one of two possible treatments, $80 \%$ or $30 \%$ canopy closure. This was manipulated by use of a shade cloth suspended on a cubical PVC frame (Figure. 3-2C).

Potted seedlings were subjected to three levels of flood duration (3 day, 10 day and 17 day) within each level of canopy closure. Potted seedlings assigned to a common flood duration (within each canopy closure level) were housed in a single crate made of galvanized steel mesh. Flooding depth was manipulated within the crates by creating PVC risers of 4 different heights $(0 \mathrm{~cm}$ or no PVC, $5 \mathrm{~cm}, 10 \mathrm{~cm}$, or $16 \mathrm{~cm})$ such that potted seedlings were held at different heights relative to the tank water level: 1) Upland treatments entirely above water, 2) moist soil treatments with soil surface $5 \mathrm{~cm}$ above water, 3) saturated treatments with soil surface even with water, and 4) inundated treatments with soil surface $5 \mathrm{~cm}$ below water. Upland treatments served as controls and were never under water. The placement of the risers within each crate was randomized to avoid confounding flooding depth with any potential shading effects (e.g. a tall riser next to a short one could potentially cause shading to the seedling). Fig. 3-3 summarizes the structure of a single experimental tank, with the hierarchically manipulated treatments.

The experiment was initiated by placing seedlings assigned to each treatment group in water filled tanks, as described previously. Flood duration was manipulated by raising the appropriate crate above the water line using plastic risers after the specified interval ( 3 days, 10 days or 17 days after the initiation of the experiment). For example, on day 3, all 3-day flood duration treatments were moved above the water line in each 
enclosure, and remained at this position for the remainder of the experiment. Fig. 3-4 illustrates the position of flooding depth treatments before and after crates were removed from the water. After the 17-day flood duration treatments were removed from the water, the tanks were emptied, and the crates were housed in the empty tank. During the final recovery period, plants were allowed to grow in the enclosures for an additional 23 days after all the flooding treatments were completed. The experiment lasted a total of 40 days from June 6 to August 15, 2010.

Plant heights (as measured from the stem base to the apical meristem) were recorded at days 0 (initial plant height), and at days 3, 10 and 17, when flood duration treatments were manipulated, and again at day 40 (conclusion of experiment). Additionally, counts of all leaves greater than $1 \mathrm{~mm}$ in length were made. Not all plants survived the 40 days of the experiment, and plants were regularly monitored for mortality, insect damage, and signs of stress at regular watering periods. At the end of the experiment the aboveground and belowground portions of each seedling were separated. Roots were cleaned by soaking them in water for several minutes, then gently rinsing them. However, heavy clay content of the soil often formed hard nodules that were difficult to remove from the plant without the loss of some root material. Aboveground portions (stems and leaves) and cleaned roots were oven dried at $55{ }^{\circ} \mathrm{C}$ for several days and weighed. Stems and leaves were weighed separately. Final aboveground biomass (AGB) of seedlings was calculated as the sum of oven-dried stem and leaf weights for each seedling, and final belowground biomass (BGB) was simply the oven-dried weight of the dried roots. The root-shoot ratio (RSR) of each plant was also calculated by dividing the root mass by the shoot mass for each individual. 
During the experimental period, the local area experienced record-breaking summer heat with little rainfall. Therefore, water was checked daily and added as needed to maintain water levels at $15 \mathrm{~cm}$ and/or to maintain the temperatures under $30^{\circ} \mathrm{C}$. Ambient air temperature inside a single experimental enclosure was measured continuously throughout the study period with a Onset HOBO temperature data logger. Soil temperatures were measured in the 17 day flooding duration crates in Tanks 1 and 6 on eight dates near the beginning of the experiment. Near the end of the flooding treatments, on July $23^{\text {rd }} 2010$, the daily soil temperature fluctuations were measured by recording soil temperatures in 17-day flooding duration crates, for all tanks, at 4 time periods ( 9 am, $1 \mathrm{pm}, 3 \mathrm{pm}$ and $5 \mathrm{pm}$ ) on a single day. All these treatments were flooded according to their assigned flooding depths during this time.

The percentage of photosynthetic photon flux density (\% PPFD) reaching plants on either side ( $80 \%$ or $30 \%$ shade) of the enclosures was estimated on two days near the beginning and end of the experiment. A LI-COR LI-250 photometer was used to take readings of photosynthetic photon flux density (PPFD in $\mu \mathrm{mol} \mathrm{m} \mathrm{m}^{-2}$, a measurement of photosynthetically active radiation, in the 400-700 $\mathrm{nm}$ wavelength range) under the open sky above each enclosure, and under each side of all 6 enclosures. These readings were taken at four times (9 am, $11 \mathrm{am}, 1 \mathrm{pm}, 3 \mathrm{pm}$ and $5 \mathrm{pm}$ ) on July $23^{\text {rd }}, 2010$. The effectiveness of shadecloth in reducing incident PPFD in enclosures was estimated by calculating $\%$ PPFD as $\frac{P_{a}}{P_{o}} \times 100$, where $P_{a}$ and $P_{o}$ are the measurements of PPFD above and inside of the enclosures, respectively. Mean \% PPFD at each time period was calculated by averaging \% PPFD across tanks $(n=6)$ for $80 \%$ or $30 \%$ shade treatments at 
each time period. These values were then averaged within each light treatment to estimate mean \% PPFD for each light treatment over the course of an entire day.

Throughout the experiment, seedlings that were at least partially in water (moist, saturated and inundated treatments) did not receive additional water. Upland treatments, and other treatments that had been raised out of the water, received supplemental water. Upland plants were initially watered to $50 \%$ soil moisture by weight (100\% soil moisture being equivalent to the soil water holding capacity). These plants were weighted approximately 3 times each week. When soil moisture dropped below 30\% (by weight), water was added to achieve $50 \%$ soil moisture. After moist, saturated and inundated treatments had been removed from the water (at 3,10 and 17 days), they were watered identically to upland treatments for the remainder of the experiment.

There were several rainfall events during the experiment. During some of these, rainfall was prevented from entering enclosures by covering them with clear plastic sheets. However, eight rainfall events resulted in rain entering the enclosures. The different types of shade cloth used on either side of the enclosures made it likely that rainfall would differ between $30 \%$ and $80 \%$ shade treatments. To correct for this effect, two plastic cups were attached at opposite ends on each side of every enclosure (2 cups/side x 2 sides/enclosure $=4$ cups/enclosure). After a rain event, the amount of water in each cup was weighed, and the average amount of rainfall on each side of the enclosure calculated. To calculate rainfall in units of mass per ground surface area $\left(\mathrm{R}_{s a}\right.$ in units of $\mathrm{g} / \mathrm{cm}^{2}$ ), we used the formula $R_{s a}=\frac{R_{m}}{A}$, where $R_{m}$ was the average amount (in $g$ ) of event rainfall in cups on each side of an enclosure, and $A$ was the surface area of the mouth of the collection cup (in $\mathrm{cm}^{2}$ ). The side of the enclosure with less rainfall was 
determined to have a deficit, which was the difference in $\mathrm{R}_{s a}$ between the two sides of each enclosure $\left(\Delta R_{s a}=\left|R_{s a_{1}}-R_{s a_{2}}\right|\right.$. The deficit of rainfall per pot $\left(\Delta R_{\text {pot }}\right.$ in $g /$ pot $)$ was calculated as $\Delta R_{p o t}=\Delta R_{s a} * A$. The calculated $\Delta R_{p o t}$ was added to each upland or raised treatment on the side of the enclosure with the deficit of rainfall.

Later in the experiment, after all treatments had been raised out of the water, it was observed that pot weights could vary more within enclosure sides, than between enclosure sides, after rainfall events. These differences were possibly due to sustained effects of previous flooding treatments, differences in evapotranspiration between plants, and effects of the experimental structures themselves. For instance, water tended to pool on the surface of the $80 \%$ shade cloth, and drip selectively on certain pots. After this was discovered (on the $24^{\text {th }}$ day of the experiment) we changed how we dealt with correction for rainfall. Instead of focusing on the differences in rainfall between sides, we focused on minimizing the variability in pot weights within each side of the enclosure. This made sense, because all plants had been removed from standing water at this point and we thus expected the weights of pots to be more similar. To achieve this correction, we weighed all pots, and calculated the mean pot weight for each side of enclosures. Pots that fell $30 \mathrm{~g}$ or more below the mean pot weight (per light or shade treatment of each tank), were watered up to the mean pot weight. This reduced the variance and range of pot weights immediately following rainfall events. 


\section{Statistical Analyses}

\section{Vertical Growth}

Growth curve analysis was used to test the hypothesis that the seedling growth response (rate of increase in plant height) is affected by light, flooding duration and flooding depth treatments, and to test for interactions in these effects. This was accomplished by constructing a linear mixed model with repeated measures and was implemented with the MIXED procedure in SAS 9.4.

To examine the effects of explanatory variables on vertical plant growth, the change in plant height over time was modeled as the continuous response variable (R) using Equation 1, where $H_{i}$ equals the plant height at day I and $H_{o}$ equals the initial plant height at the beginning of the experiment.

$$
R=H_{i}-H_{o} \quad \text { Equation } 1
$$

The explanatory variables were number of days, light (shade cloth treatment), flooding duration, flooding depth, block, and plant ID. Number of days was modeled as a continuous variable, where values of the response variable were calculated for $0,3,7$, 10 and 40 days. Light was modeled as a fixed factor with two levels: simulated open canopy (30\% shade cloth) and simulated closed canopy (80\% shade cloth)). Flooding duration was modeled as a continuous variable with possible values of 3,10 and 17 days. Flooding depth was modeled as a continuous variable with possible values of $0,1,2$, and 3, which correspond, respectively, to the ranked flooding depths of upland (no flooding), moist, saturated and inundated described previously. The variable, block, was treated as a random effect with values 1-6, each corresponding to a replicate experimental tank. 
Finally, a unique identifier for each seedling, plant ID, was modeled as the subject effect in a repeated measures design, using autoregressive-1 $(\mathrm{AR}(1))$ covariance structure. This covariance structure is commonly used with repeated-measures time series data to handle autocorrelation of within-subjects error terms.

To make the analysis sensitive to a wide range of possible effects, a polynomial model was used. Terms up to degree two for number of days, degree two in flooding depth and flooding duration (combined), and one degree in light were included in the initial model to allow detection of any significant non-linear responses. Thus, no term exceeded degree 5.

The full, initial model is described below (Equation 2), where $\mathrm{R}_{(\mathrm{t}, \mathrm{u}, \mathrm{v}, \mathrm{w})}$ is the change in plant height over time (from Equation 1) modeled as a polynomial function of time $(t)$, flooding depth $(u)$, flooding duration $(v)$ and light treatments $(w)$, and $b_{i}(u, v, w)$ is the coefficient of $t$ raised to the $i$ th degree. Since $t$ was modelled up to degree two, coefficients for $t$ and $t^{2}\left(b_{1}(u, v, w)\right.$ and $b_{2}(u, v, w)$, respectively) were modelled as defined in Equation 3 and Equation 4; subscripts indicate the polynomial degree of factors $u, v$, and $w$ in each term for flooding depth, flooding duration and light treatment, respectively. For instance, $b_{1,0,0,0}$ (in Equation 2) denotes the coefficient of $t$ when the degree of $u=0, v=0$ and $w=0$ (e.g. main effects of ndays). Main effects of flooding duration, flooding depth and light were not included, because these variables can only affect the response variable as number of days increases. 


$$
\begin{array}{cc}
R_{(t, u, v, w)}=b_{1}(u, v, w) * t+b_{2}(u, v, w) * t^{2} & \text { Equation 2 } \\
b_{1}(u, v, w)=b_{1,0,0,0}+b_{1,1,0,0} u+b_{1,0,1,0} v+ & \text { Equation 3 } \\
b_{1,0,0,1} w+b_{1,1,1,0} u v+b_{1,2,0,0} u^{2}+b_{1,0,2,0} v^{2}+ & \\
b_{1,1,0,1} u w+b_{1,0,1,1} v w+b_{1,1,1,1} u v w+b_{1,2,0,1} u^{2} w+ & \\
b_{1,0,2,1} v^{2} w & \\
b_{2}(u, v, w)=b_{2,0,0,0}+b_{2,1,0,0} u+b_{2,0,1,0} v+ & \\
b_{2,0,0,1} w+b_{2,1,1,0} u v+b_{2,2,0,0} u^{2}+b_{2,0,2,0} v^{2}+ & \text { Equation 4 } \\
b_{2,1,0,1} u w+b_{2,0,1,1} v w+b_{2,1,1,1} u v w+b_{2,2,0,1} u^{2} w+ & \\
b_{2,0,2,1} v^{2} w &
\end{array}
$$

Runs of the full model produced residuals that were highly skewed to the right.

Additionally, plots of residuals vs. predicted values revealed a dramatically wedgeshaped pattern, indicating heteroscedasticity. Using a transform of the response variable was found to produce normally distributed residuals and satisfied the assumptions of homogeneity of variance when residuals were plotted against explanatory variables. This transform is shown in Equation 5, where $\Delta h$ is the plant height on a given day minus the plant height at day 0 . Since some values of $\Delta h$ were negative, and the natural log is not defined for negative values (which occurred if the seedling became necrotic), a value of 3 was added to $\Delta h$ before taking the natural $\log$, and then $\ln (3)$ subtracted from this value.

$$
R=\ln (\Delta h+3)-\ln (3)
$$

\section{Equation 5}

By definition, this transform results in a response value of 0 for all plants when number of days $=0$. Therefore, an intercept of zero was set, and only values of $3,10,17$ 
and 40 were used for number of days. Positive response values when number of days=3, 7, 10 or 40 indicate positive growth, and negative values indicate negative growth (e.g. dieback).

Backward elimination using Akaike's Information Criterion (AIC) was used to reduce the number of terms and produce a more parsimonious model. Terms of the highest degree were sequentially removed one at a time from the model and AIC computed. A term was omitted from the model if its removal lowered AIC by 2 or more units. If the removal of a term increased AIC or decreased AIC by less than 2 units, it was retained in a reduced model. This reduced model was then subject to one more round of backward elimination using the same elimination criteria, resulting in a final reduced model.

\section{Leaf Number Response}

A nearly identical procedure was used to develop a model testing the effects of the same suite of explanatory variables on the increase in leaf number over time. Similar to plant height, leaf number is a continuous variable that was measured where number of days $=0,3,1017$, or 40 days). The initial, full model was identical to that shown in Equation 2, where the variable $R_{(t, u, v, w)}$ takes the values shown in Equation 6. Here, $\Delta n$ is the number of leaves at day $3,10,17$ or 40 minus the number of leaves at day 0 (i.e. the change in leaf number). In order to produce normally distributed model residuals, and meet the assumptions of equal variance, $\Delta n$ was transformed, and a constant (40) was used to avoid taking the natural $\log$ of a negative number. The "unstructured" variance structure (UN) was used in place of $\operatorname{AR}(1)$. 


$$
R=\ln (\Delta n+40)-\ln (40)
$$

Equation 6

Backward elimination of terms to produce a simplified model of the leaf number response was performed as described previously for the vertical growth model using AIC as the elimination criterion.

\section{Biomass Data}

The effects of light, flooding depth and flooding duration on AGB were modeled with a mixed-linear model using the PROC MIXED procedure in SAS 9.4. Seedlings that died before the end of the experiment were omitted from this analysis; failure to promptly remove seedlings from the field after death made biomass data from these treatments unusable. The inundated treatments were most impacted by these omissions, and therefore biomass data from all inundated seedlings was omitted from the analysis due to the large imbalance in sample size this created. Fixed effects of light and flooding variables included all one-, two- and three-way interactions. Experimental block and initial plant height were included as random effects using the variance components covariance structure. Identical specifications were used for two additional models using BGB and RSR as response variables.

Model residuals were examined for normality and homoscedasticity and the response variables were transformed, if necessary, to improve data fit. BGB was transformed by taking the square root, and RSR by taking the natural log. 


\section{$\underline{\text { Results }}$}

\section{Environmental Factors}

Average temperatures during the study period of 2010 (June-August) were the second highest on record in Kentucky (NCEI 2016). The mean daily air temperature inside the monitored enclosure (from July 10 ${ }^{\text {th, }}$ 2010-August 15, 2010) ranged from 21.77 ${ }^{\circ} \mathrm{C}$ to $33.42{ }^{\circ} \mathrm{C}$, averaging $28.17 \pm 0.35{ }^{\circ} \mathrm{C}$. The mean daily minimum and maximum were $22.26 \pm 0.04{ }^{\circ} \mathrm{C}$ and $36.25 \pm 0.44{ }^{\circ} \mathrm{C}$, respectively

Soil temperature displayed a temperature gradient that directly paralleled differences in flooding depth (see Fig. 3-5), with unflooded soils being the hottest, and inundated the coolest. he most complete record of daily soil temperature variations was made on the fourth hottest day of the experimental period (7/23/10), when ambient air temperature averaged $30.89 \pm 0.59{ }^{\circ} \mathrm{C}$ (range: $25.56-37.44{ }^{\circ} \mathrm{C}$ ). Based on soil temperature data collected at four time points on this day, unflooded soil temperatures showed the greatest daily temperature variation, with the mean temperature varying $8.37^{\circ} \mathrm{C}$ and 6.07 ${ }^{\circ} \mathrm{C}$ for $30 \%$ and $80 \%$ shade treatments, respectively. The mean temperature of inundated soils fluctuated approximately $5^{\circ} \mathrm{C}$ for both light treatments.

Photometer readings made the same day estimate mean \% PPFD over the course of a day as $55.87 \pm 0.03 \%$ and $17.94 \pm 0.01 \%$ for $30 \%$ and $80 \%$ shade treatments, respectively. 


\section{Seedling Growth: Vertical Growth}

No terms containing light as a factor were retained in the final model using backward elimination. Therefore all seedling data from both light treatments were pooled for subsequent analyses. The final model retained six terms relating number of days, flooding depth treatment and flooding duration to change in plant height.

Fig. 3-6 illustrates the growth curves for all treatment combinations using mean values of the observed and predicted response variable. As shown, the observed growth response closely approximates the predicted values from the model; thus the chosen regression model appears to accurately describe the plant growth response.

Table 3-1 summarizes the results of the final polynomial regression where change in plant height (transformed variable) was used as the response variable. Statistically significant $\mathrm{p}$-values for coefficients of first and second order terms for number of days (nDays, $\mathrm{p}<0.0001$ and $n$ Days $^{2}, \mathrm{p}<0.0001$ ) shows that seedlings exhibited an increase in height over time, and this response was non-linear.

Significant effects of flooding duration, flooding depth and interactions between these terms are indicated by several tests (Table 3-1). The effects of flooding depth on linear growth $(n$ Days*flood depth $)$ were found to be significant and negative $(\mathrm{p}<0.0001)$. Additionally, the interaction effect of coefficients for number of days, flooding depth, and flooding duration was found to be statistically significant and negative (nDays*flood depth $*$ flood duration, $\mathrm{p}=<0.0001)$. This indicates that flooding depth and flooding duration had linear, non-additive effects on linear plant growth (change in height) over 
the course of the experiment. A negative coefficient for this interaction indicates that increasing values of flood duration or flooding depth (by level), or a combination of the two, have negative effects on vertical plant growth.

The panels in Figs. 3-6 through 3-8 illustrate the effects of flooding depth at different flooding durations on the plant height response variable over the course of the experiment. At flood durations of 3 days (Fig. 3-7), treatments of all flooding depths showed a positive net increase in height over the 40 day experimental run with upland control and moist treatments maintaining higher growth rates than saturated and inundated treatments.

At longer flooding durations, the upland controls and moist treatments maintained positive growth, while the saturated and inundated treatments experienced periods of negative growth (e.g. dieback). Despite periods of negative growth within the 10 day flooding treatments, the saturated seedlings showed positive net growth over the course of the experiment, while the inundated seedlings experienced net dieback (Fig. 3-8).

Treatments with the longest flooding duration (17 days) showed the most dramatic differences in growth rate between flooding depth treatments (Fig. 3-9). Growth curves of these treatments clearly show the effects of the flooding gradient; control, moist, saturated and inundated seedlings had the highest to lowest growth rates, respectively. Seedlings subjected to moist conditions for 17 days maintained positive growth throughout the course of the experiment, intermediate between those of upland controls and seedlings saturated for 17 days. 
Seedlings saturated for 17 days, similar to seedlings saturated or inundated for 10 days, experienced a period of average dieback from 10-17 days, but exhibited modest growth during the recovery period (17-41 days). In contrast, seedlings inundated for 17 days experienced net dieback from 10-17 days, and did not survive the recovery period.

Two second-order terms (nDays*nDays*Flood Depth and nDays*nDays*Flood Duration*Flood Depth) were found to be significant and positive indicating that both flooding depth and the interaction between flood depth and flood duration affect the shape of the growth curve.

A significant positive effect of flood duration on plant growth (nDays*Flood Duration, $\mathrm{p}=0.0271$ ) was indicated by the model, but is apparent in only one case. Plants receiving 10 days of moist "flooding" outperformed upland control which were never flooded (flood duration $=0$ days). This could be explained by constant moisture providing seedlings with an advantage over upland seedlings during period when temperatures were high. Considering the significant negative coefficient for the term nDays*sublevel*duration, it appears that the positive effects of increasing flooding duration on plant growth are overshadowed by the interaction effects between flood duration and flood depth.

The subject effect (the ID of an individual seedling) was significant $(\mathrm{p}<0.0001)$, indicating that there was variation in the plant growth response due to individual differences in seedlings $(\mathrm{p}<0.0001)$. Experimental block was not found to have a statistically significant effect on plant height response $(\mathrm{p}=0.07)$. 


\section{Seedling Growth: Leaf Number}

Similar to the vertical growth model, no terms containing light were retained in the final model for change in leaf number. Therefore, all seedling data were pooled for subsequent analyses. The final model retained five terms involving interactions between number of days, flood duration and flood depth (Table 3-2).

Fig. 3-10 illustrates a close correspondence between response curves generated using observed and predicted values for change in leaf number, one indicator of good model fit. The term nDays, but not $n$ Days $^{2}$, was retained in the model, and was highly significant $(\mathrm{p}<0.0001)$, indicating that change in leaf number $(\Delta$ leaf number/day) followed a pattern of linear increase in the absence of other variables, as can be seen for the unflooded control treatment in Fig. 3-10 (upper left corner, Flood Duration = 0, Flood Depth=0 (unflooded)).

As with the vertical growth models, tests of significance indicated that flood duration had significant positive effects on the change in leaf number over time (nDays *flood duration, $\mathrm{p}<0.0001$ ), but that this effect was moderated by a negative interaction with flood depth (nDays*Flood Depth*Flood Duration, $p<0.0001)$. Thus the effects of flooding depth on the change in leaf number over time vary with flooding duration.

Figs. 3-10 through 3-12 depict the change in leaf number over the duration of the experimental period for different flooding depths, within each flood duration. As with the response curves for vertical growth, little difference between flooding depth treatments is evident with 3 days of flooding (Fig. 3-11) and the net mean change in leaf 
number was positive for treatments of all flooding depths over the course of the experiment. Differences between flooding depth treatments became apparent at flooding durations of 10 days (Fig. 3-12). There was a steady loss of leaves from days 3-17 in seedlings saturated or inundated for 10 days, while moist treatments maintained an increase in leaf number. From 17-40 days, however, these seedlings showed signs of recovery, exhibiting a slow increase in leaf number. It should be noted that $66 \%$ of seedlings subjected to 10 day inundation died before the end of the experiment (see following Plant Survival section); thus the estimates of change in leaf number during latter time points are based on a smaller sample size of surviving seedlings only. Similar to 10 day flooding treatments, seedlings saturated or inundated for 17 days showed a steady decline in leaf number from days $3-17$, with saturated seedlings showing signs of recovery between days 17-41 (Fig. 3-13).

\section{Plant Survival}

The number of days lived for moist and saturated treatment groups remained similar to the upland control (38.6 \pm 1.0 days), regardless of flood duration). However, seedlings inundated for 10 or 17 days had noticeably shorter lifespans than all other treatments (29.8 \pm 2.9 and 27.2 \pm 1.5 days, respectively). No seedlings inundated for 17 days survived past 17 days. Mean days lived, proportion surviving, and other statistics are summarized by all combinations of flood duration and flood depth in Table 3-3.

\section{Biomass}

Light levels appeared to be of primary importance in biomass determination and root-shoot ratio. Light treatment was a significant predictor of AGB $(\mathrm{p}<0.0001$; Table 3- 
4), with mean AGB being higher in all $30 \%$ shade treatments, at all combinations of flood depth and duration (Fig. 3-14). AGB generally declined with increasing flood duration and depth, but this response was not monotonic, and varied with light level. For instance, while AGB generally decreased with flood duration for $80 \%$ shade treatments, moist treatments in $30 \%$ shade showed a non-monotonic response to increasing flood duration (Fig. 3-15). Thus, the relative impact of flooding variables on AGB appears to vary somewhat with light treatment, as indicated by significant p-values for the interaction terms Flood Duration*Light and Flood Duration*Flood Depth*Light.

Similarly, BGB was significantly higher in $30 \%$ shade than $80 \%$ shade treatments (Table 3-5), and this trend was evident across all combinations of flood duration and depth. However, differences between $30 \%$ and $80 \%$ shade appeared more pronounced in unflooded controls that moist or saturated treatments (Fig. 3-16), which likely accounts for the significance interaction between flood depth and light ( $\mathrm{p}=0.0234)$. A significant negative interaction $(\mathrm{p}=0.041)$ between flood depth and duration indicates BGB declines with increasing values of either, or both of these variables, and that their combined effect on BGB is non-additive. 
The RSR of seedlings was only related to light (Table 3-6), with significantly higher mean RSR in 30\% shade than $80 \%$ shade treatments. This indicates a higher biomass allocation to belowground biomass in the higher light environment. However, this trend was not consistent across all combinations of flooding depth and duration; treatments with moist conditions for 10 or 17 days did not show this trend (Fig. 3-17). Differences in RSR between light treatments were most obvious with unflooded controls.

Neither experimental block, nor initial plant height were significant covariates in any of the models.

\section{$\underline{\text { Discussion }}$}

The results of this study are meant to serve as a starting point for gauging the potential success or failure of Lonicera maackii establishment in wetland areas under a range of hydrologic conditions. Brief inundation or saturation of seedlings (3 days) did not appear to have large impacts on seedling growth curves, and did not significantly reduce the number of days lived. Inundation and saturation of seedlings for 10 to 17 days appears to have a markedly negative effect on honeysuckle seedlings as shown by slow vertical growth or dieback and loss of leaves. Seedlings exhibited some ability to recover from flooding stress, once drawdown had occurred; seedlings saturated or inundated for 10 days or saturated for 17 days exhibited a net increase in height and leaf number during days 17-40 (no seedlings flooded during this time), after previously showing decreases in these variables. Despite negative growth effects on saturated seedlings, only inundated seedlings demonstrated a significantly reduced lifespan compared to unflooded controls. 
Effects of light treatments on plant growth were evident in biomass data, but not vertical stem growth or leaf number increase. The lack of significant light effect on stem growth and leaf number was unexpected, considering results from (Luken et al. 1997) in which L. maackii plants were grown at three light levels (1\%, 25\% and 100\% of PPFD). In their study, Lonicera plants achieved maximum relative stem growth rates and had higher leaf numbers at $100 \%$ PPFD, and demonstrated the ability to acclimate and increase photosynthetic rates with greater light availability. Contrary to this, the experimental data from our study showed generally higher stem growth rates in the low light treatments. The relatively short time frame of this experiment (5.7 weeks) may explain this apparent lack of light effect on vertical growth and leaf number. In a different study by Luken et al. (1995), forest-grown seedlings were transplanted to shadehouses providing 5\%, 25\% and $100 \%$ of PPFD, with maximum stem growth initially associated with the $25 \%$ PPFD treatments in the first 3 weeks of the experiment. However, this pattern shifted later in the experiment, with seedlings attaining maximum stem growth in $100 \%$ PPFD treatments in weeks 3-7, as seedlings produced new leaves with higher carbon capture abilities. Our experiment lasted under 6 weeks and examined stem growth integrated over the entire experimental period, thus we may not have had ample time to see a positive growth response to enhanced light.

Both aboveground and belowground biomass were significantly higher in high light treatments, which agrees with findings from Luken et al. (1997, 1995). Thus, while light did not significantly impact vertical stem growth or leaf number over the experimental period, higher biomass and higher root-shoot ratios in high light treatments suggests that seedlings may have responded to higher light levels with more horizontal 
growth and/or thicker leaves and investment in belowground ground resources than more shaded seedlings. However, we did not measure horizontal growth or leaf thickness, and these suggestions are speculative. Significant main effects of light on root-shoot ratio indicate that seedlings grown in the more shaded environment generally allocated more biomass aboveground. This finding is also confirmed by Luken et al. (1997), who attributed this as a "light-seeking response" by a shade-intolerant plant that contributes to its ability to overgrow slower growing species. Interactions between light and flooding variables were significant predictors of seedling biomass (ABG and $\mathrm{BGB}$ ) and suggest that flooding characteristics may moderate the relationship between plant biomass and light. The lack of significant interactions between light and flooding variables RSR suggests that the biomass allocation of Lonicera maackii seedlings is similar across flooding depths and durations.

\section{Caveats}

Average temperatures during June-August of 2010 were the second warmest on record in Kentucky. Despite measures to keep soil and water temperatures at a minimum (i.e. daily refreshment of tank water and surrounding pots with reflective foil), because of the relatively small size of the pots and tanks used, soil and water temperatures were likely to exceed those encountered in a natural setting — particularly during peak daylight hours. This may have adversely affected plants in multiple ways. Heat-stress can negatively affect nearly all aspects of plant performance, including growth, development and metabolism (Hasanuzzaman et al. 2013). High microbial respiration, combined with high plant oxygen demand and lower dissolved oxygen solubility in warm, water-logged soils may also have exacerbated the anaerobic stresses typical of wetland soils. Soil 
pathogens also may benefit from higher soil temperatures, increasing susceptibility to root rot. Since we have no basis for assessing how much these factors contributed to plant performance, direct extrapolation of these results to natural systems must be considered with caution.

As a result of experimental design, plants with shorter flood durations had longer recovery periods after the simulated drawdown. However, if the experimental design were altered to standardize the length of the recovery, then the experimental periods for different treatments would differ in length. Alternately, standardizing the length of recovery and timing of drawdown would cause total experimental length to vary with flooding duration and force the initiation of experimental flooding to begin on different days. This could potentially create experimental artifacts, since the seasonal timing of flooding events may influence plant growth (Robertson, Bacon, \& Heagney, 2001). Since the effects of seasonal flood timing are not questions addressed by this study, we chose to synchronize flooding events, and allow recovery periods to vary in length.

\section{Implications}

The impact of L. maackii on regional forests appears to have broad implications on ecosystem functions and services, with no established solutions for its effective and efficient eradication on a large scale. Due to the presence of seasonally high water tables, forested wetlands appear to be less susceptible to L. maackii dominance than adjacent upland systems. However, as seen in the last chapter, this species is capable of invading wetland areas and establishing itself as the dominant shrub species. Considering the greater variation in regional weather patterns that are predicted to occur as a result of 
climate change, the vulnerability of these systems to L. maackii incursion may change. Specifically, summer drought conditions may be more frequent in this region (midwestern United States) because of warmer summer temperatures and increasing variability in precipitation patterns (Field, 2007), which may potentially make a greater area of bottomland hardwood forest favorable for Lonicera sp. colonization. This information should be relevant to restoration practitioners who seek to recreate natural microtopography and disturbance regimes of wetland forests, while minimizing the abundance of exotic invasive species.

There is also some limited evidence to suggest that L. maackii may enhance stand transpiration, and thus could contribute to shortened hydroperiods in ephemeral wetland areas. In a case study comparing stand transpiration in depressional wetlands with relatively high and low basal area of L. maackii, (Boyce et al. (2012)) estimated that approximately $10 \%$ of stand transpiration was due to L. maackii. Because L. maackii appeared to be adding to, not replacing, the native shrub layer, they suggested that this species may actually be increasing evapotranspiration in these wetlands. This scenario has the potential to create a positive feedback loop where L. maackii alter wetland hydrology, creating drier conditions, and thus facilitating its spread in wetland systems.

\section{Conclusions}

The growth of Lonicera maackii seedlings in this study was negatively impacted by flooded (saturated or inundated) conditions in this study. This coincides with previous studies indicating that the distribution of $L$. maackii is limited by standing water and that flooding has a negative impact on L. maackii in at least one life stage (also see 
Chapter II of this manuscript). However, seedlings exhibited some ability to recover from flooding stresses when subjected to saturation for up to 17 days or inundation up to 10 days. This was in spite of near record high air temperatures and periodically high soil temperatures. These results provide evidence for some resiliency to flooding stress ability to become established in intermittently saturated or inundated areas. Therefore, factors that may alter wetland hydrology and shorten hydroperiods can facilitate the invasion of this exotic species in wetland areas. These factors include the urban heat island effect and climate change (which may increase stand evapotranspiration (Jackson et al. 2001)), as well as direct human modification of wetland areas. 
Table 3-1. Model coefficient estimates and significance values for final mixed linear model testing effects of linear and non-linear variable combinations on plant growth response (change in plant height). Coefficient estimates are not interpretable in the original scale of measurement, since they are based on transformed data.

\begin{tabular}{|c|c|c|c|c|c|c|}
\hline & Effect & Estimate & $\begin{array}{c}\text { Standard } \\
\text { Error } \\
(+/-)\end{array}$ & $\mathrm{DF}$ & t Value & $P>|t|$ \\
\hline \multirow{8}{*}{$\begin{array}{c}\text { Fixed } \\
\text { Effects }\end{array}$} & nDays*Flood & -0.0010 & 0.0001 & 532 & -7.79 & $<.0001$ \\
\hline & Depth*Flood Duration & & & & & \\
\hline & $\begin{array}{c}n \text { Days } * n \text { Days*Flood } \\
\text { Depth }\end{array}$ & 0.0003 & 0.0000 & 532 & 7.07 & $<.0001$ \\
\hline & nDays*Flood Depth & -0.0131 & 0.0021 & 532 & -6.23 & $<.0001$ \\
\hline & nDays*Flood Duration & 0.0008 & 0.0002 & 532 & 3.94 & $<.0001$ \\
\hline & $n$ Days*nDays & -0.0011 & 0.0001 & 532 & -14.30 & $<.0001$ \\
\hline & nDays & 0.0807 & 0.0038 & 532 & 21.03 & $<.0001$ \\
\hline & & Estimate & $\begin{array}{c}\text { Standard } \\
\text { Error } \\
(+/-)\end{array}$ & & $\begin{array}{c}\mathrm{Z} \\
\text { Value }\end{array}$ & $\mathrm{p}$ \\
\hline $\begin{array}{c}\text { Random } \\
\text { Effects }\end{array}$ & Block & 0.02797 & 0.01893 & & 1.48 & $<.0001$ \\
\hline $\begin{array}{l}\text { Repeated- } \\
\text { measures }\end{array}$ & Subject=Plant Id & 0.7558 & 0.02649 & & 28.53 & $<.0001$ \\
\hline
\end{tabular}


Table 3-2 Model coefficient estimates and significance values for final mixed linear model testing effects of linear and non-linear variable combinations on change in leaf number. Coefficient estimates are not interpretable in the original scale of measurement, since they are based on transformed data.

\begin{tabular}{|c|c|c|c|c|c|c|}
\hline & Effect & Estimate & $\begin{array}{c}\text { Standard } \\
\text { Error } \\
(+/-)\end{array}$ & $\mathrm{DF}$ & t Value & $\mathrm{p}$ \\
\hline & $\begin{array}{l}\text { nDays*Flood Depth* } \\
\text { Flood Depth }\end{array}$ & -0.0002 & 0.0006 & 530 & -0.36 & 0.7184 \\
\hline & nDays*Flood Depth & 0.0004 & 0.0018 & 530 & 0.25 & 0.8044 \\
\hline & nDays*Flood Duration & 0.0008 & 0.0002 & 530 & 4.26 & $<.0001$ \\
\hline & \multirow[t]{2}{*}{ nDays } & 0.0061 & 0.0008 & 530 & 7.57 & $<.0001$ \\
\hline & & Estimate & $\begin{array}{c}\text { Standard } \\
\text { Error } \\
(+/-) \\
\end{array}$ & & $\begin{array}{c}\mathrm{Z} \\
\text { Value }\end{array}$ & $\mathrm{p}$ \\
\hline $\begin{array}{l}\text { Random } \\
\text { Effects }\end{array}$ & Block & 0.0014 & 0.0010 & & 1.46 & 0.0724 \\
\hline
\end{tabular}


Table 3-3. Mean, minimum and maximum days lived for all combinations of flooding depth and flooding duration (light treatments pooled). Proportion surviving at the end of the experiment (Day 40) is also shown.

\begin{tabular}{cccccccc}
\hline \hline $\begin{array}{c}\text { Flood } \\
\text { Duration }\end{array}$ & $\begin{array}{c}\text { Flood } \\
\text { Depth }\end{array}$ & $\mathrm{N}$ & $\begin{array}{c}\text { Mean } \\
\text { Days } \\
\text { Lived }\end{array}$ & $\begin{array}{c}\text { Standard } \\
\text { Error } \\
(+/-)\end{array}$ & Minimum & Maximum & $\begin{array}{c}\text { Proportion } \\
\text { Surviving }\end{array}$ \\
\hline 0 & $\begin{array}{c}\text { Unflooded } \\
\text { (Control) }\end{array}$ & 36 & 38.6 & 1.0 & 14 & 40 & 0.94 \\
3 & Moist & 12 & 40.0 & 0.0 & 40 & 40 & 1.00 \\
& Saturated & 12 & 38.4 & 1.6 & 21 & 40 & 0.92 \\
& Inundated & 12 & 40.0 & 0.0 & 40 & 40 & 1.00 \\
10 & Moist & 12 & 40.0 & 0.0 & 40 & 40 & 1.00 \\
& Saturated & 12 & 39.8 & 0.3 & 37 & 40 & 0.92 \\
& Inundated & 12 & 29.8 & 2.9 & 14 & 40 & 0.33 \\
& Moist & 12 & 36.5 & 2.4 & 14 & 40 & 0.83 \\
& Saturated & 12 & 40.0 & 0.0 & 40 & 40 & 1.00 \\
& Inundated & 12 & 27.2 & 1.5 & 21 & 37 & 0.00 \\
\hline \hline
\end{tabular}


Table 3-4. Model coefficient estimates and significance values for mixed linear model testing effects of fixed (main and interaction effects) and random effects on aboveground biomass of seedlings, as measured at the end of the experiment. Significant p-values are in bold.

\begin{tabular}{|c|c|c|c|c|c|c|c|}
\hline & Parameter & Light & Estimate & $\begin{array}{c}\text { Standard } \\
\text { Error } \\
(+/) \\
\end{array}$ & DF & t Value & $\mathrm{p}$ \\
\hline \multirow{11}{*}{$\begin{array}{c}\text { Fixed } \\
\text { Effects }\end{array}$} & Intercept & & 0.1337 & 0.1192 & 92.4 & 1.12 & 0.2651 \\
\hline & Light & $\begin{array}{l}\text { Light } \\
\text { Shade }\end{array}$ & 0.3389 & 0.0651 & 88.4 & $\begin{array}{r}5.20 \\
.\end{array}$ & $<.0001$ \\
\hline & Flood Depth & & -0.0199 & 0.04967 & 88.2 & -0.40 & 0.6903 \\
\hline & Flood Duration & & 0.0075 & 0.0095 & 88.1 & 0.78 & 0.4372 \\
\hline & $\begin{array}{c}\text { Flood } \\
\text { Duration } * \text { Light }\end{array}$ & Light & 0.0418 & 0.0144 & 88.6 & 2.90 & 0.0047 \\
\hline & & Shade & 0 & . & . & . & . \\
\hline & Flood Depth*Light & $\begin{array}{l}\text { Light } \\
\text { Shade }\end{array}$ & $\begin{array}{r}-0.0832 \\
0\end{array}$ & 0.0723 & 88.4 & -1.15 & 0.2525 \\
\hline & Flood & & -0.0113 & 0.0068 & 88.1 & -1.67 & 0.0976 \\
\hline & $\begin{array}{l}\text { Depth }{ }^{*} \text { Flood } \\
\text { Duration } \\
\text { Light*Flood }\end{array}$ & Light & -0.0225 & 0.0099 & 88.4 & -2.28 & 0.0251 \\
\hline & $\begin{array}{c}\text { Duration } * \text { Flood } \\
\text { Depth }\end{array}$ & Shade & 0 & . & - & . & \\
\hline & & & Estimate & $\begin{array}{c}\text { Standard } \\
\text { Error } \\
(+/-)\end{array}$ & & $\begin{array}{c}\mathrm{Z} \\
\text { Value }\end{array}$ & $\mathrm{p}$ \\
\hline \multirow{2}{*}{$\begin{array}{l}\text { Random } \\
\text { Effects }\end{array}$} & Block & & 0.003288 & 0.003515 & & 0.94 & 0.1748 \\
\hline & Initial Plant Height & & 0.002789 & 0.004000 & & 0.70 & 0.2428 \\
\hline
\end{tabular}


Table 3-5. Model coefficient estimates and significance values for mixed linear model testing effects of fixed (main and interaction effects) and random effects on belowground biomass of seedlings, as measured at the end of the experiment. Significant p-values are in bold.

\begin{tabular}{|c|c|c|c|c|c|c|c|}
\hline & Parameter & Light & Estimate & $\begin{array}{c}\text { Standard } \\
\text { Error } \\
(+/) \\
\end{array}$ & $\overline{\mathrm{DF}}$ & t Value & $\bar{p}$ \\
\hline Fixed & Intercept & & -2.1277 & 0.2237 & 5 & -9.51 & 0.0002 \\
\hline \multirow[t]{12}{*}{ Effects } & Light & Light & 0.6536 & 0.1257 & 87 & 5.20 & $<.0001$ \\
\hline & & Shade & 0 & & . & & \\
\hline & Flood Depth & & 0.1196 & 0.0959 & 87 & 1.25 & 0.2156 \\
\hline & Flood Duration & & 0.0219 & 0.0184 & 87 & 1.19 & 0.2383 \\
\hline & $\begin{array}{c}\text { Flood } \\
\text { Duration*Light }\end{array}$ & Light & -0.0244 & 0.0290 & 87 & -0.84 & 0.4020 \\
\hline & & Shade & 0 & & & & \\
\hline & Flood Depth*Light & Light & -0.3222 & 0.1396 & 87 & -2.31 & $\mathbf{0 . 0 2 3 4}$ \\
\hline & & Shade & 0 & & & & 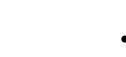 \\
\hline & $\begin{array}{c}\text { Flood Depth*Flood } \\
\text { Duration }\end{array}$ & & -0.0270 & 0.0131 & 87 & -2.07 & 0.0413 \\
\hline & Light $*$ Flood & Light & 0.0257 & 0.0194 & 87 & 1.32 & 0.1887 \\
\hline & $\begin{array}{c}\text { Duration } * \text { Flood } \\
\text { Depth }\end{array}$ & Shade & 0 & & . & . & 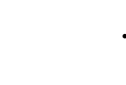 \\
\hline & & & Estimate & $\begin{array}{c}\text { Standard } \\
\text { Error } \\
(+/-)\end{array}$ & & $\begin{array}{c}\mathrm{Z} \\
\text { Value }\end{array}$ & $\mathrm{p}$ \\
\hline Random & Block & & 0.003260 & 0.0074 & & 0.44 & 0.3306 \\
\hline Effects & Initial Plant Height & & 0.003891 & 0.0057 & & 0.68 & 0.2477 \\
\hline
\end{tabular}


Table 3-6. Model coefficient estimates and significance values for mixed linear model testing effects of fixed (main and interaction effects) and random effects on the rootshoot ratio of seedlings, as measured at the end of the experiment. Significant p-values are in bold.

\begin{tabular}{|c|c|c|c|c|c|c|c|}
\hline & Parameter & Light & Estimate & $\begin{array}{c}\text { Standard } \\
\text { Error } \\
(+/)\end{array}$ & $\overline{\mathrm{DF}}$ & t Value & | \\
\hline Fixed & Intercept & & -1.2244 & 0.1578 & 3.01 & -7.76 & 0.0044 \\
\hline \multirow[t]{13}{*}{ Effects } & Light & Light & 0.3419 & 0.1087 & 89.5 & 3.15 & 0.0022 \\
\hline & & Shade & 0 & . & & . & . \\
\hline & Flood Duration & & 0.0125 & 0.0162 & 89.3 & 0.77 & 0.4404 \\
\hline & Flood Depth & & 0.1231 & 0.0840 & 89.4 & 1.47 & 0.1463 \\
\hline & Flood & Light & -0.0314 & 0.0243 & 90.5 & -1.30 & 0.1984 \\
\hline & & Shade & 0 & & & & \\
\hline & Flood Depth*Light & Light & -0.2236 & 0.1217 & 89.6 & -1.84 & 0.0696 \\
\hline & & Shade & 0 & . & • & • & \\
\hline & Flood & & -0.0133 & 0.0114 & 89.4 & -1.17 & 0.2470 \\
\hline & $\begin{array}{c}\text { Duration*Flood } \\
\text { Depth }\end{array}$ & & & & & & \\
\hline & Flood & Light & 0.0277 & 0.0166 & 89.9 & 1.67 & 0.0992 \\
\hline & Duration $*$ Flood & Shade & 0 & . & $\cdot$ & $\cdot$ & • \\
\hline & & & Estimate & $\begin{array}{c}\text { Standard } \\
\text { Error } \\
(+/-)\end{array}$ & & $\begin{array}{c}\mathrm{Z} \\
\text { Value }\end{array}$ & $\mathrm{p}$ \\
\hline Random & Block & & 0.00219 & 0.0055 & & 0.40 & 0.3454 \\
\hline Effects & Initial Height & & 0.0001 & 0.0004 & & 0.40 & 0.3454 \\
\hline
\end{tabular}




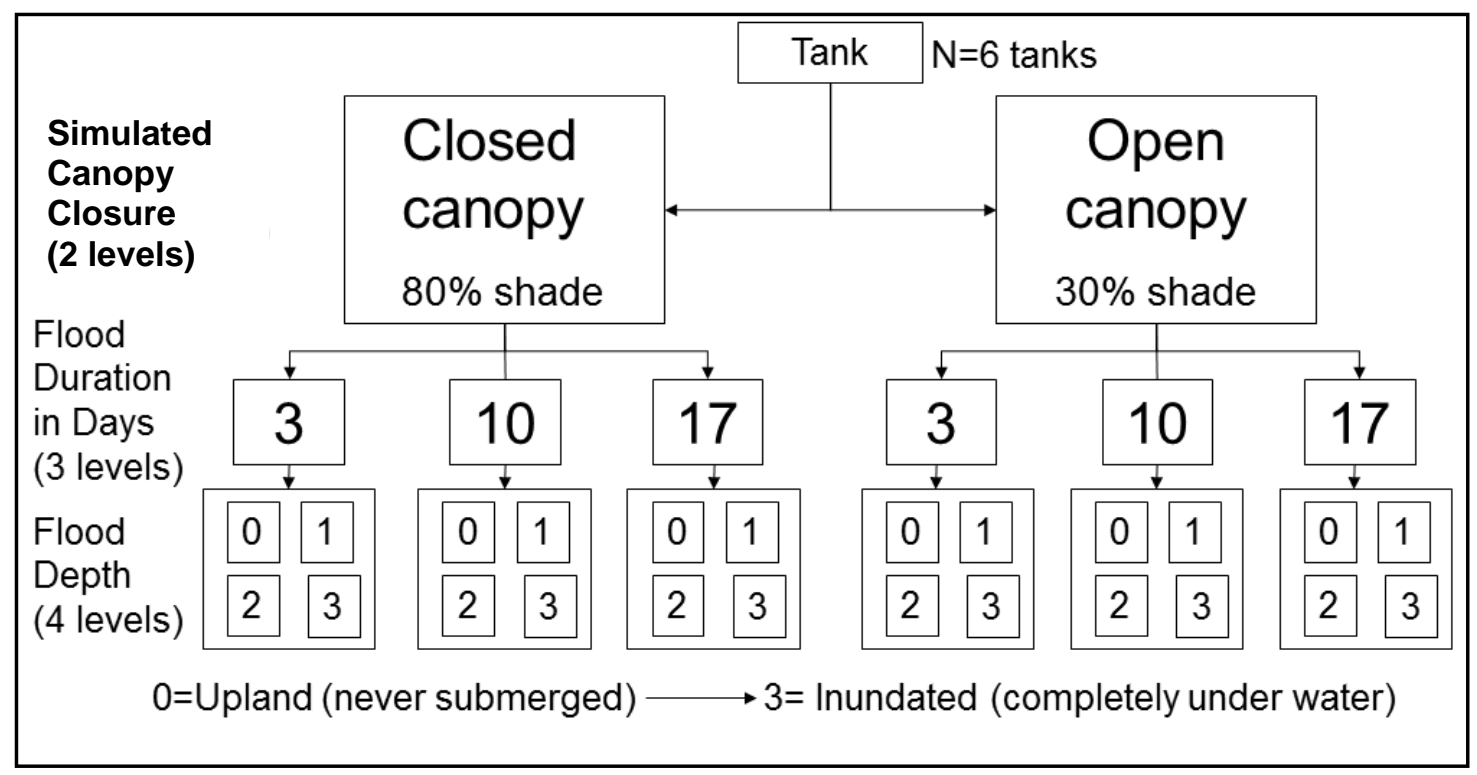

Figure 3-1. Graphical summary of split-split plot experimental design, showing nested structure of variables. Four levels of flood depth are nested within three levels of flood duration, which are both nested within two levels of simulated canopy closure. Each one of six tanks contained all these treatments. 


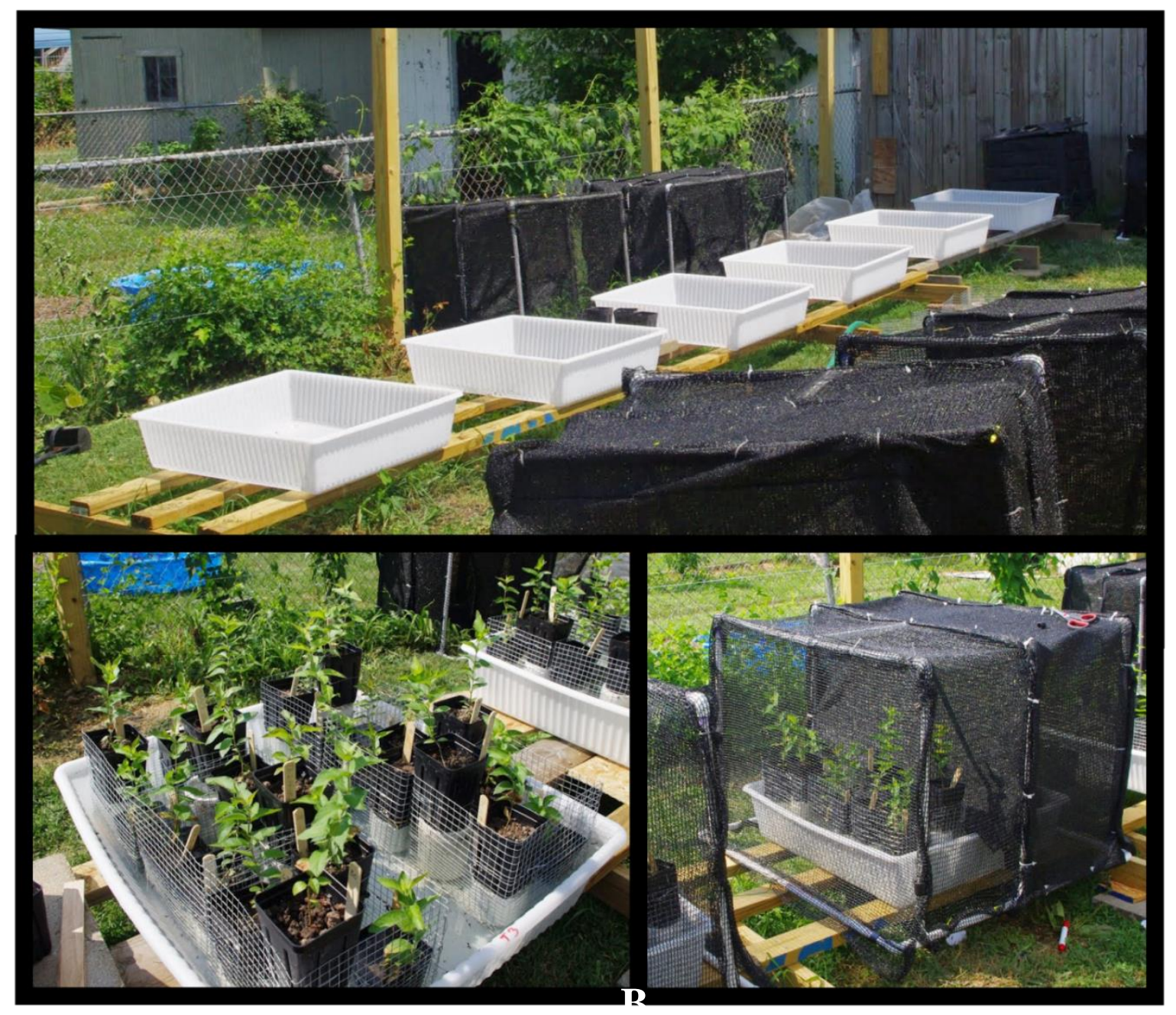

Figure 3-2. Outdoor mesocosm construction. A. The six experimental tanks arranged on a level, wooden riser. B. Seedlings arranged within a single experimental tank, without surrounding shade cloth enclosure. Metal crates on each side of the tank (three per side) correspond to the three different flooding durations, each containing four seedlings (one of each flooding depth). C. A completed mesocosm with a shade cloth enclosure. Each shade cloth enclosure bisected the tank into two light treatments (30\% and $80 \%$ shade). 


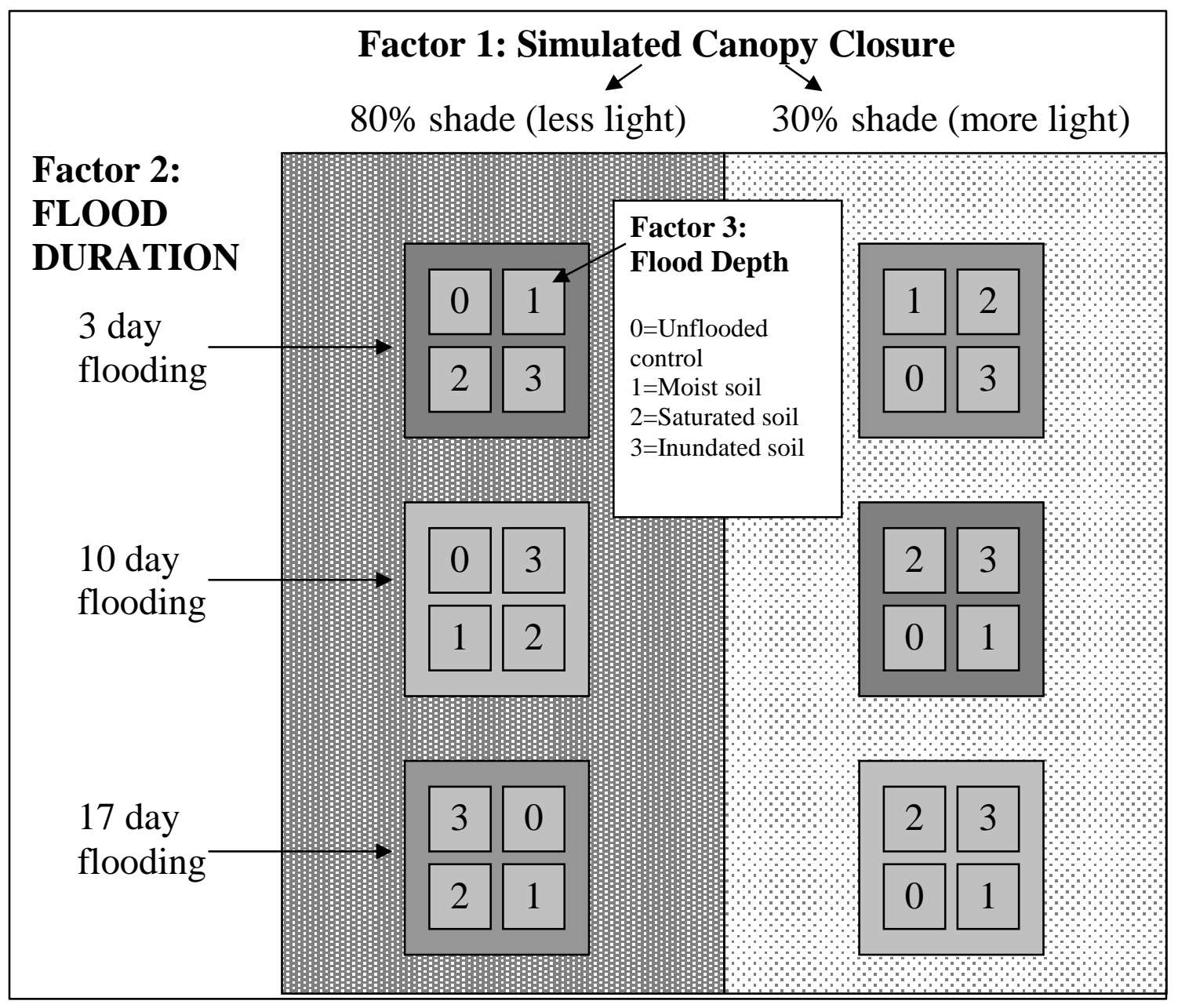

Figure 3-3. Graphical summary of split-split plot design for each experimental tank $(n=6)$. This should be interpreted as a top-down view. 


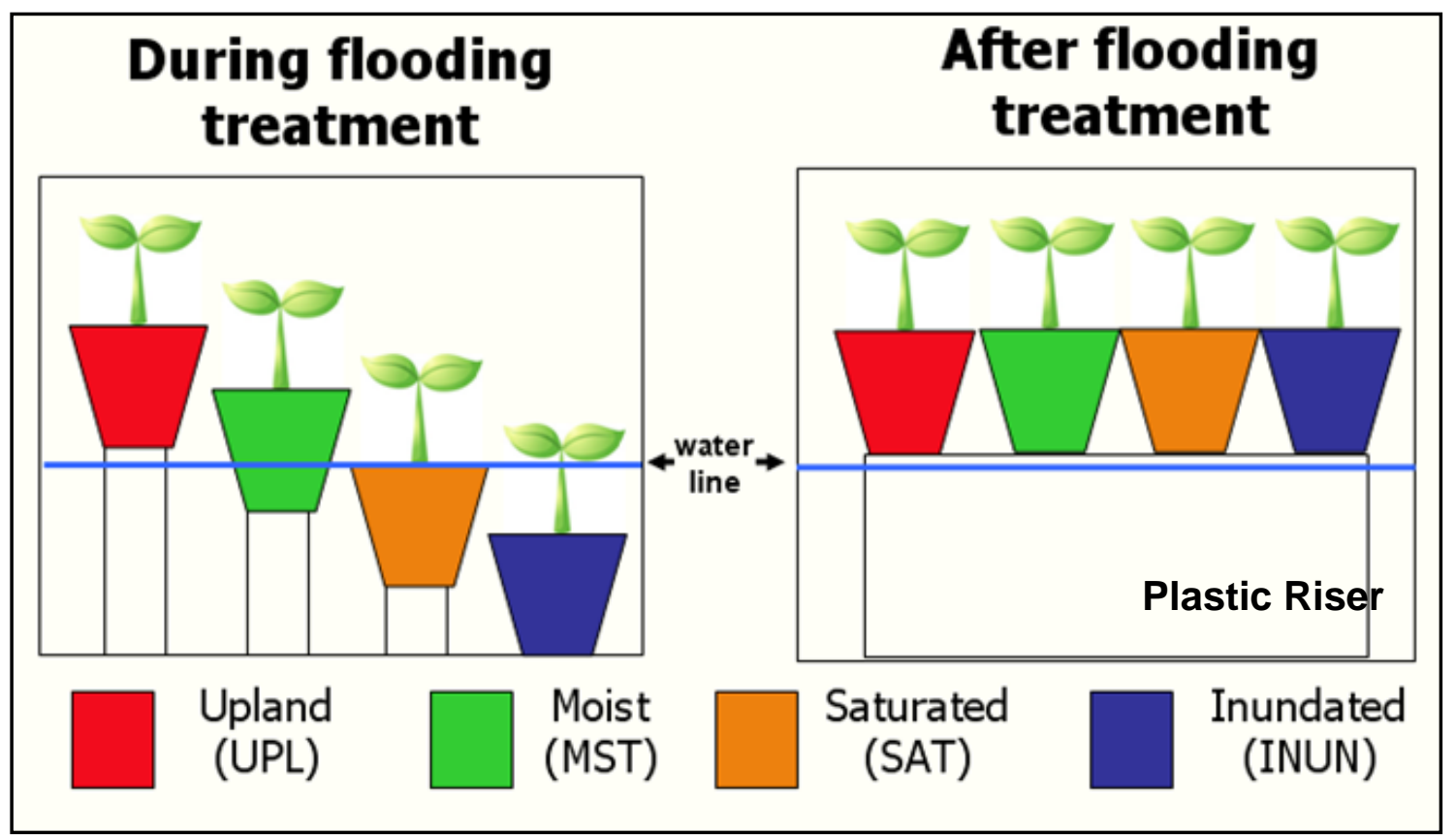

Figure 3-4. Graphical explanation showing flood depth and flood duration manipulations. The box on the left depicts the relative position of flooding depth treatments within a given crate. Crates were assigned one of three flood durations (3, 10 or 17 days) on each side (30\% or $80 \%$ shade) of a tank enclosure. After the period of assigned flood duration had lapsed for a given crate, it was held above the water line on a plastic riser, with all pots sitting on the bottom of the crate. 


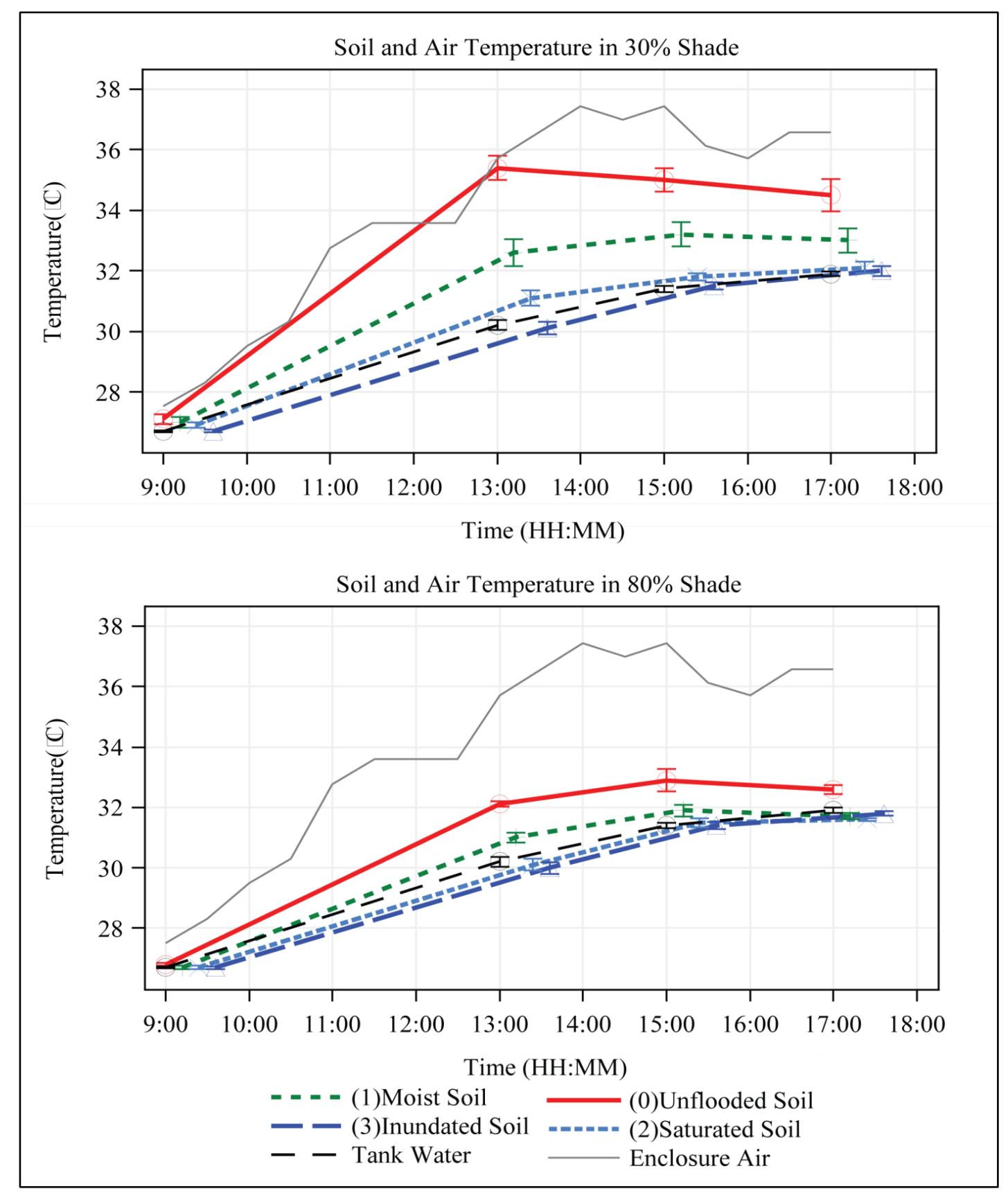

Figure 3-5. Daily changes in temperature for soil, water and air in enclosures, as measured on July $23^{\text {rd }}, 2010$. Panels show mean temperature curves for $30 \%$ and $80 \%$ shade treatments in the top and bottom panels, respectively. Enclosure air temperature was gathered from a single data logger placed at the center of the enclosure (i.e. at the boundary of the two light treatments) in tank 3 only. The same data for enclosure air temperature and water temperature is shown in both panels, to serve as a reference. Error bars are \pm one standard error. Soil temperatures are means based on measurements 17 day flooding treatments within each light treatment, in each tank $(n=6$ for each data point). Water temperature data is identical in the top and bottom panels, and is the mean water temperature based on measurements in each tank ( $n=6$ for each data point). 
Flood Duration

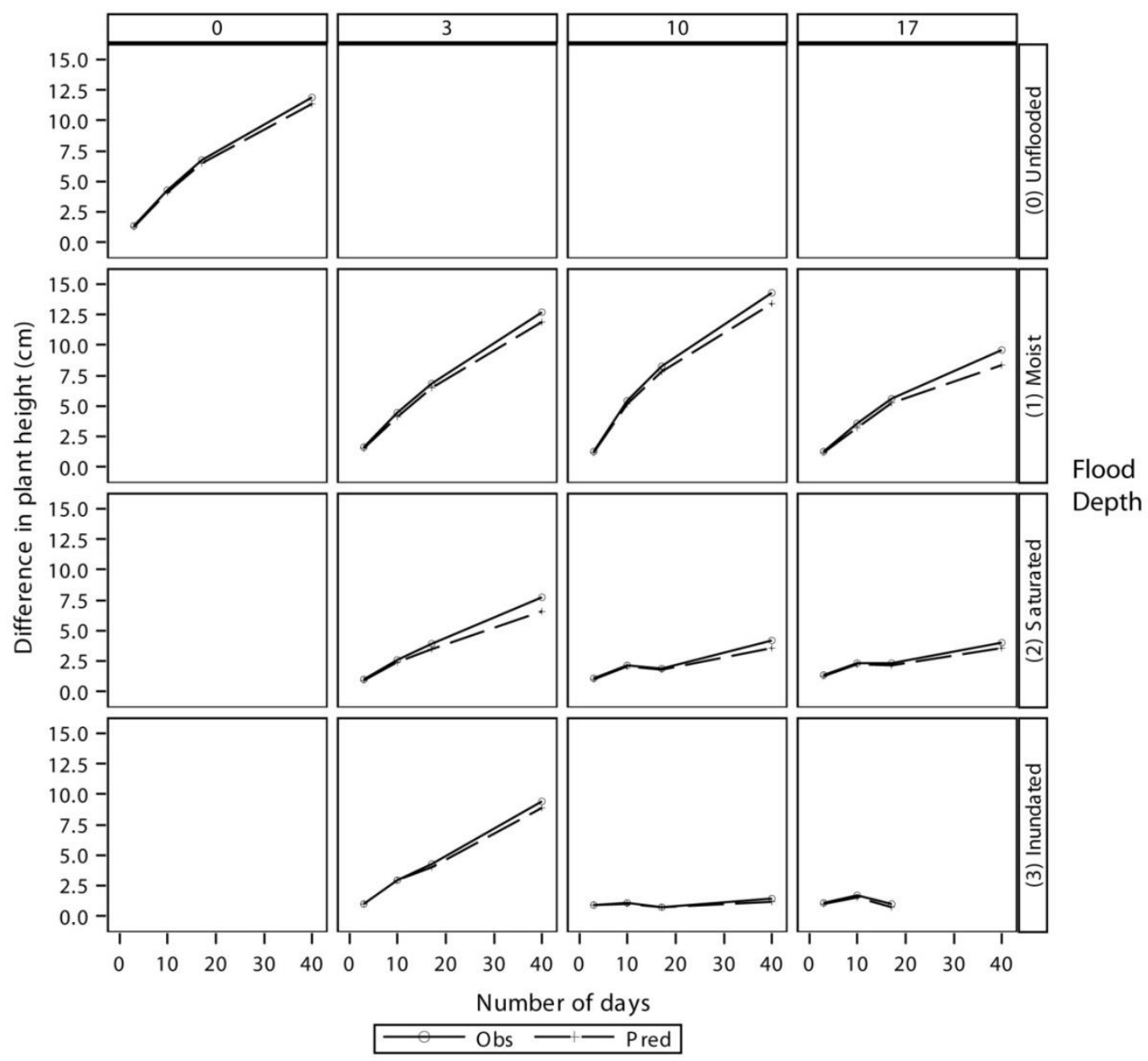

Figure 3-6. Mean observed (solid line) vs. predicted (dashed line) growth curves for seedlings over the full 40 days of the experiment. Each cell depicts the mean growth for treatments belonging to each combination of flooding depth and flooding duration. Flooding depth increases from top to bottom (see right vertical axis) and flooding duration increases from left to right (see top horizontal axis). 


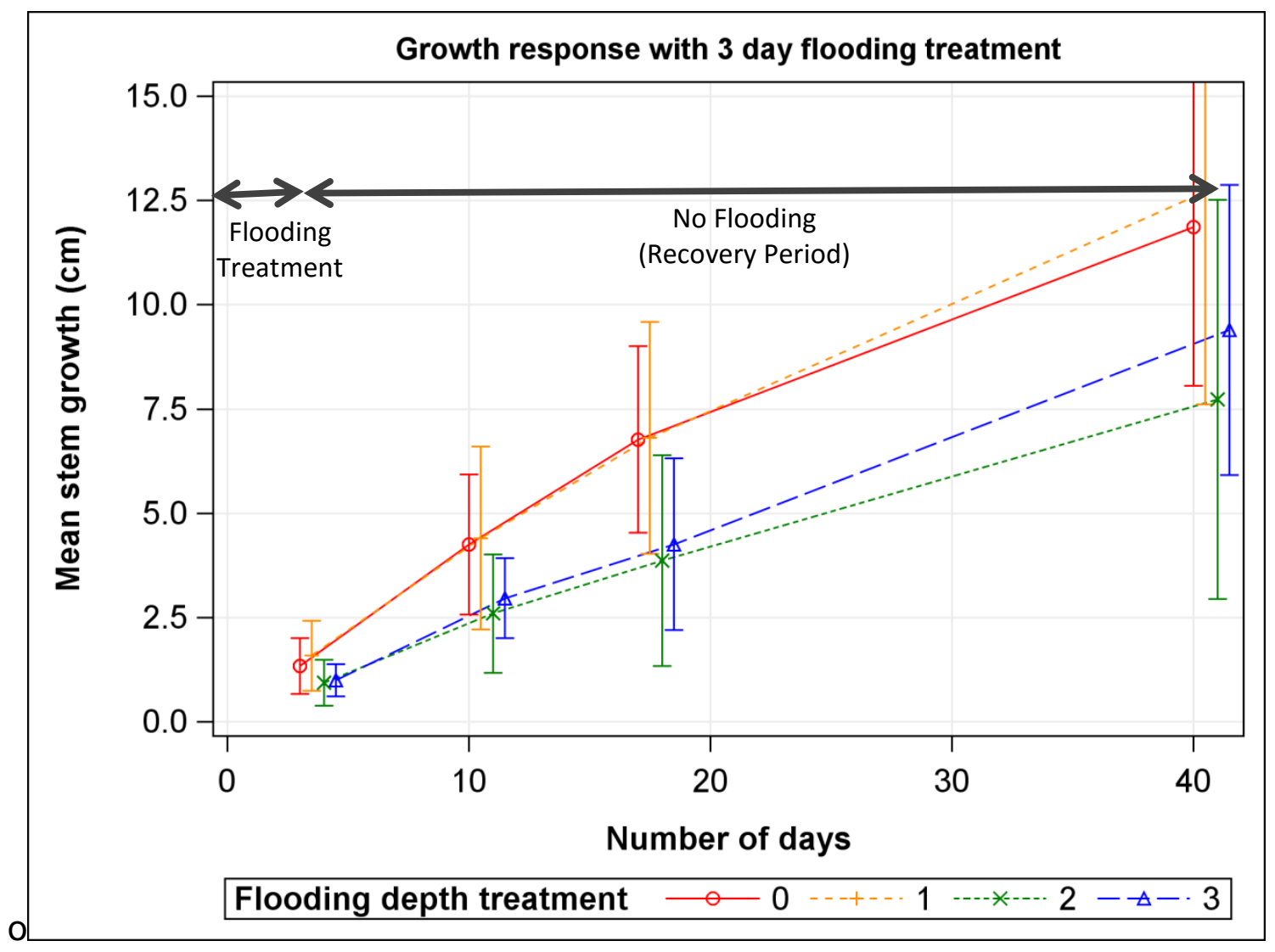

Figure 3-7. Stem growth response of seedlings subjected to moist $(1 \mathrm{in}+)$, saturated ( 2 in $\mathrm{x}$ ), and inundated ( 3 in $\Delta$ ) flooding conditions for 3 days. The growth response of upland controls (never flooded) are also shown in red ( 0 in red circle) as a reference. Graph depicts the growth response of the seedlings over the entire duration of the study. Error bars are $+/-1$ standard deviation. Dates for each treatment are staggered a day or two on graph to permit outcomes on each sampling date to be discerned more easily. But all dates were: 3, 10, 17 and 40 after initial submergence treatment on day zero. 


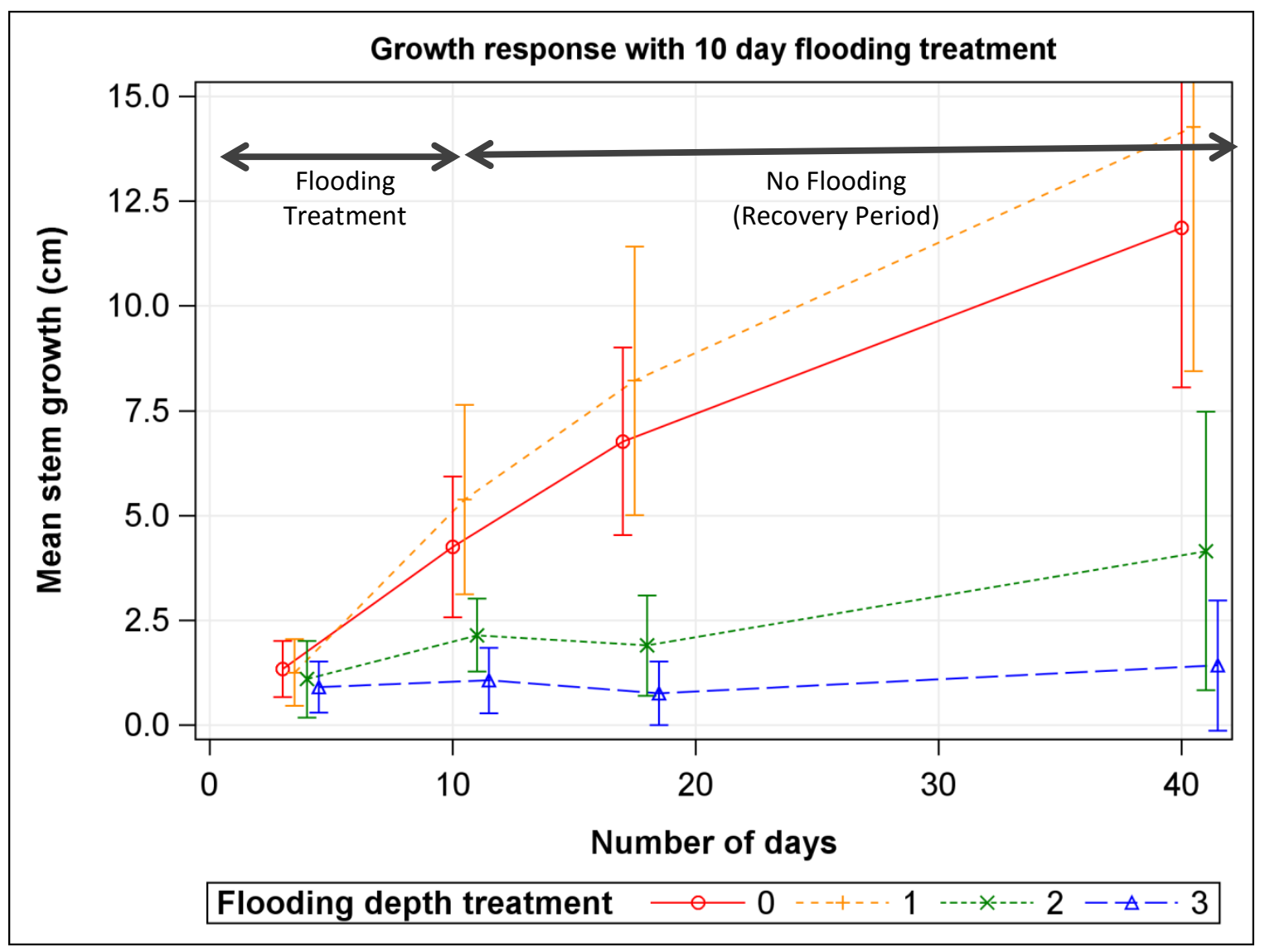

Figure 3-8. Stem growth response of seedlings subjected to moist (1 in + ), saturated (2 in $\mathrm{x}$ ), and inundated ( 3 in $\Delta$ ) flooding conditions for 10 days. The growth response of upland controls (never flooded) are also shown in red. Graph depicts the growth response of the seedlings for the duration of the 40-day study. Error bars are $+/-1$ standard deviation. Dates for each treatment are staggered a day or two on graph to permit outcomes on each sampling date to be discerned more easily, but all dates were: 3 , 10, 17 and 40 after initial submergence treatment on day zero. 


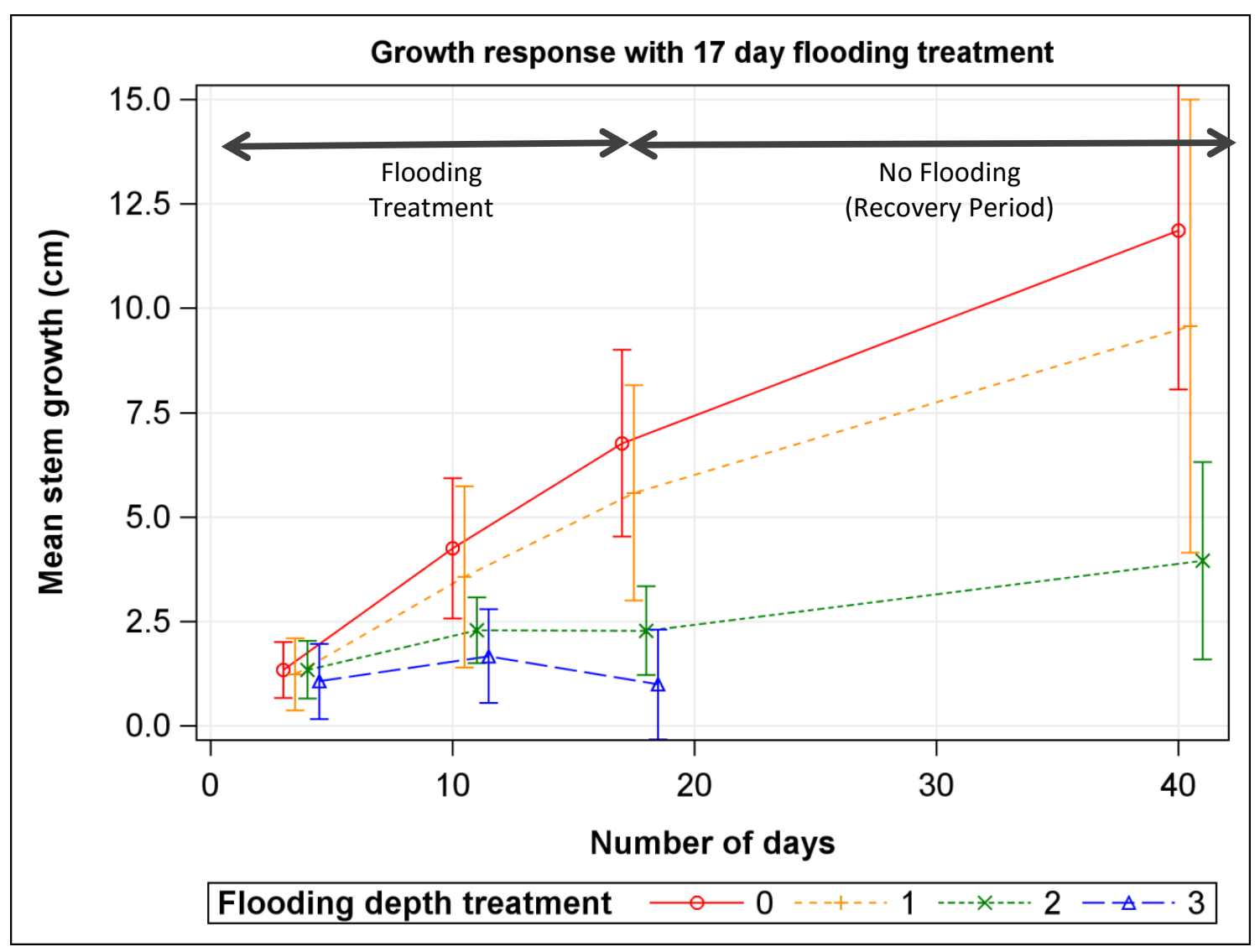

Figure 3-9 Stem growth response of seedlings subjected to moist (1 in +), saturated (2 in $\mathrm{x}$ ), and inundated ( 3 in $\Delta$ ) flooding conditions for 17 days. The growth response of upland controls (never flooded) are also shown in red. Graph depicts the growth response of the seedlings for the duration of the study. Error bars are $+/-1$ standard deviation. Dates for each treatment are staggered a day or two on graph to permit outcomes on each sampling date to be discerned more easily. But all dates were: 3,10 , 17 and 40 after initial submergence treatment on day zero. 


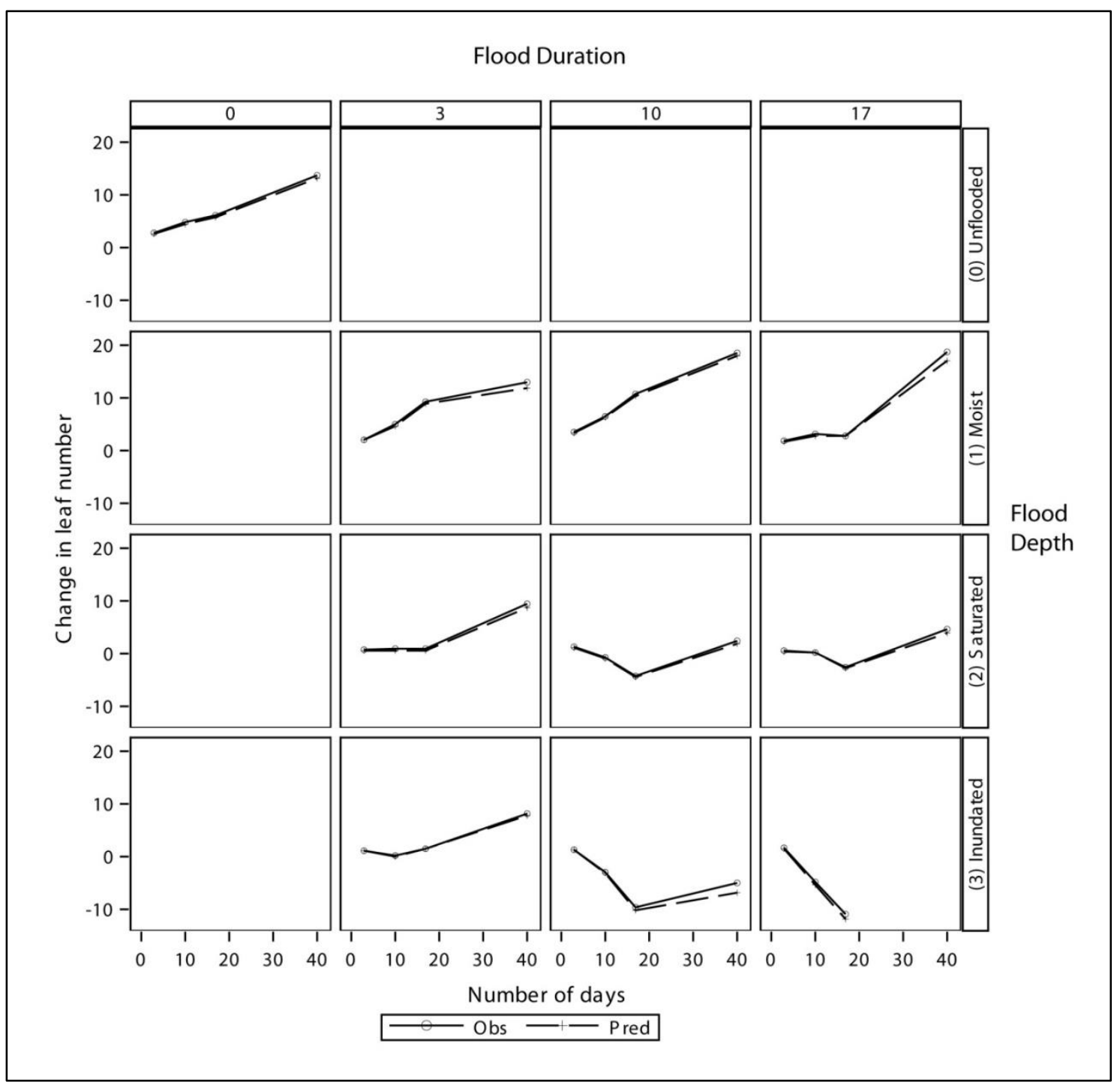

Figure 3-10. Mean observed (solid line) vs. predicted (dashed line) curves for change in seedling leaf number over the full 40 days of the experiment. Each cell depicts the mean change in leaf number for treatments belonging to each combination of flooding depth and flooding duration. Flooding depth increases from top to bottom (see right vertical axis) and flooding duration increases from left to right (see top horizontal axis). 


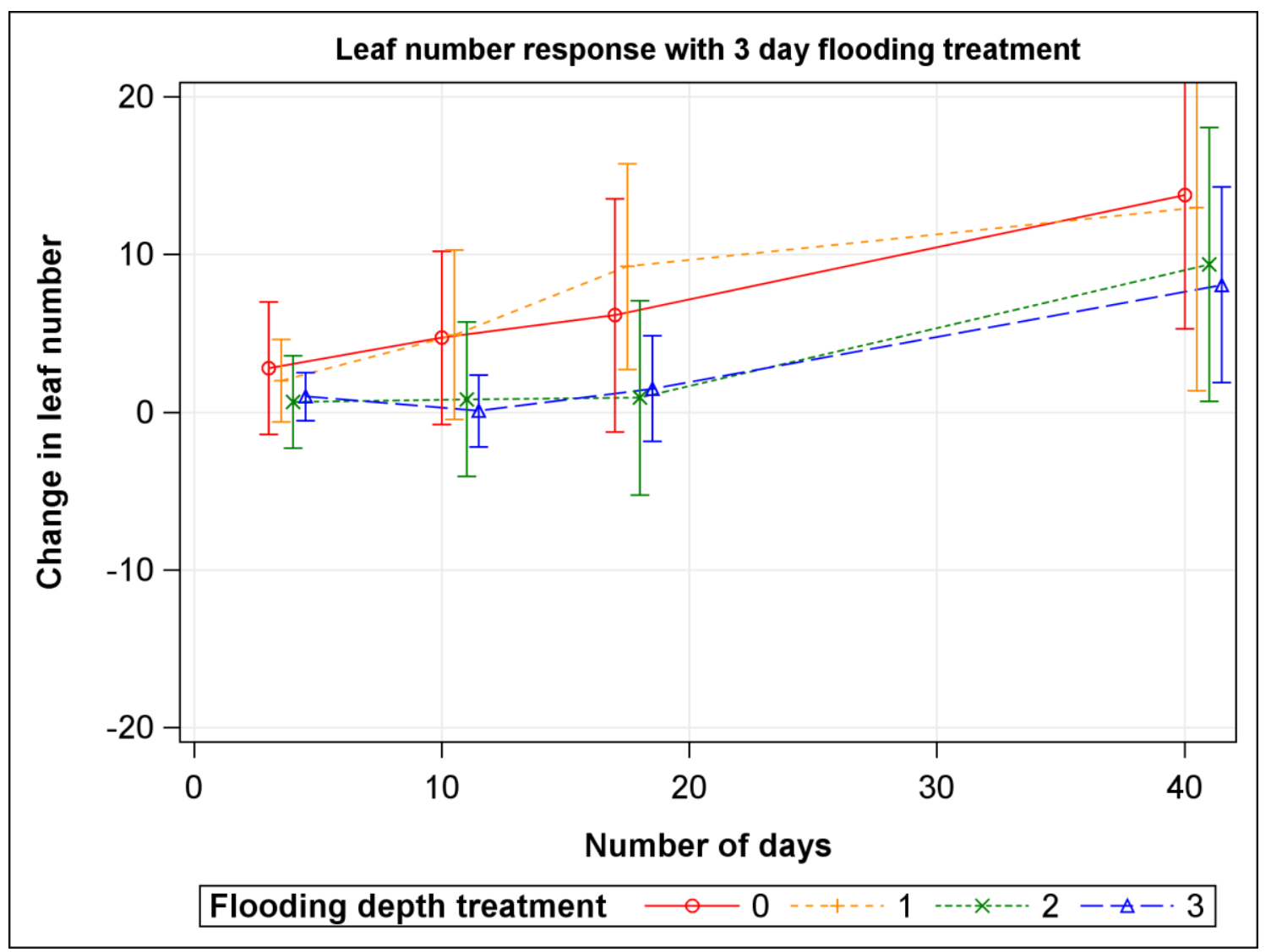

Figure 3-11. Change in leaf number for seedlings subjected to moist $(1$ in +$)$, saturated (2 in $\mathrm{x}$ ), and inundated ( 3 in $\Delta$ ) flooding conditions for 3 days. The growth response of upland controls (never flooded) are also shown in red. Graph depicts the growth response of the seedlings for the duration of the study. Error bars are $+/-1$ standard deviation. Dates for each treatment are staggered a day or two on graph to permit outcomes on each sampling date to be discerned more easily. But all dates were: 3, 10, 17 and 40 after initial submergence treatment on day zero. 


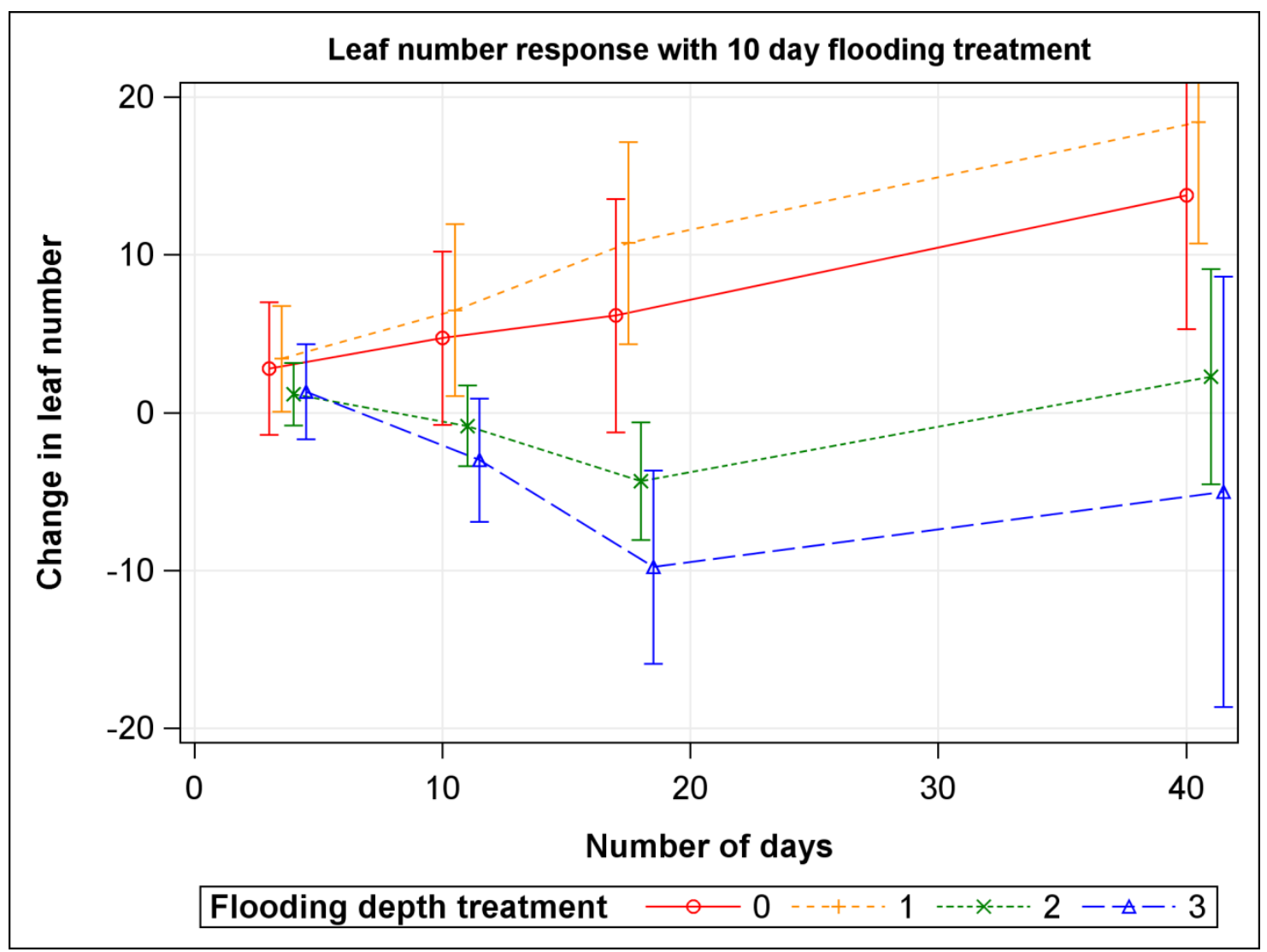

Figure 3-12. Change in leaf number for seedlings subjected to moist ( 1 in + ), saturated (2 in $\mathrm{x}$ ), and inundated ( 3 in $\Delta$ ) flooding conditions for 10 days. The growth response of upland controls (never flooded) are also shown in red. Graph depicts the growth response of the seedlings for the duration of the study. Error bars are $+/-1$ standard deviation. Dates for each treatment are staggered a day or two on graph to permit outcomes on each sampling date to be discerned more easily. But all dates were: 3, 10, 17 and 40 after initial submergence treatment on day zero. 


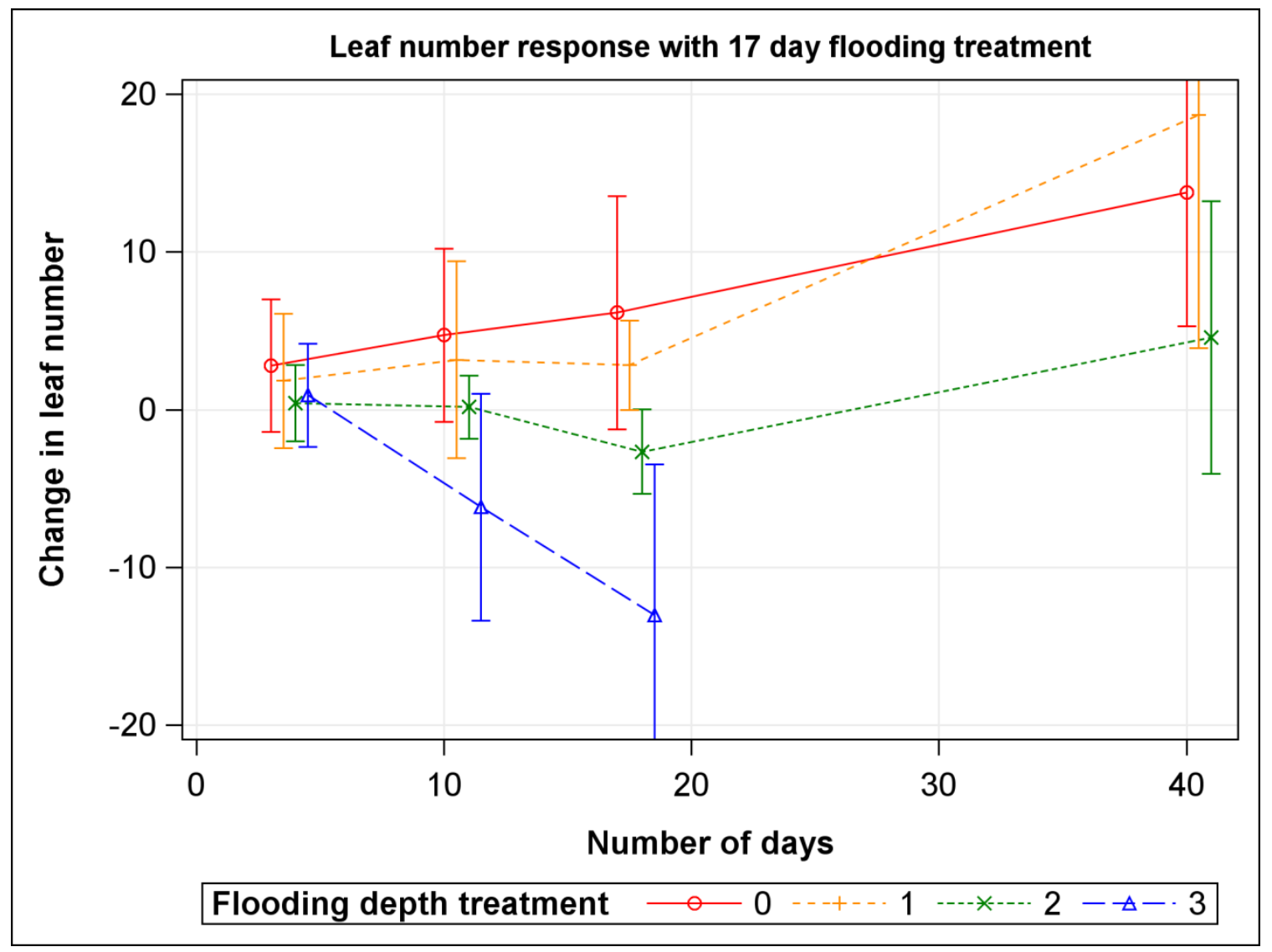

Figure 3-13. Change in leaf number for seedlings subjected to moist ( 1 in +$)$, saturated (2 in $\mathrm{x}$ ), and inundated ( 3 in $\Delta$ ) flooding conditions for 17 days. The growth response of upland controls (never flooded) are also shown in red. Graph depicts the growth response of the seedlings for the duration of the study. Error bars are $+/-1$ standard deviation. Dates for each treatment are staggered a day or two on graph to permit outcomes on each sampling date to be discerned more easily. But all dates were: , 10, 17 and 40 after initial submergence treatment on day zero. 


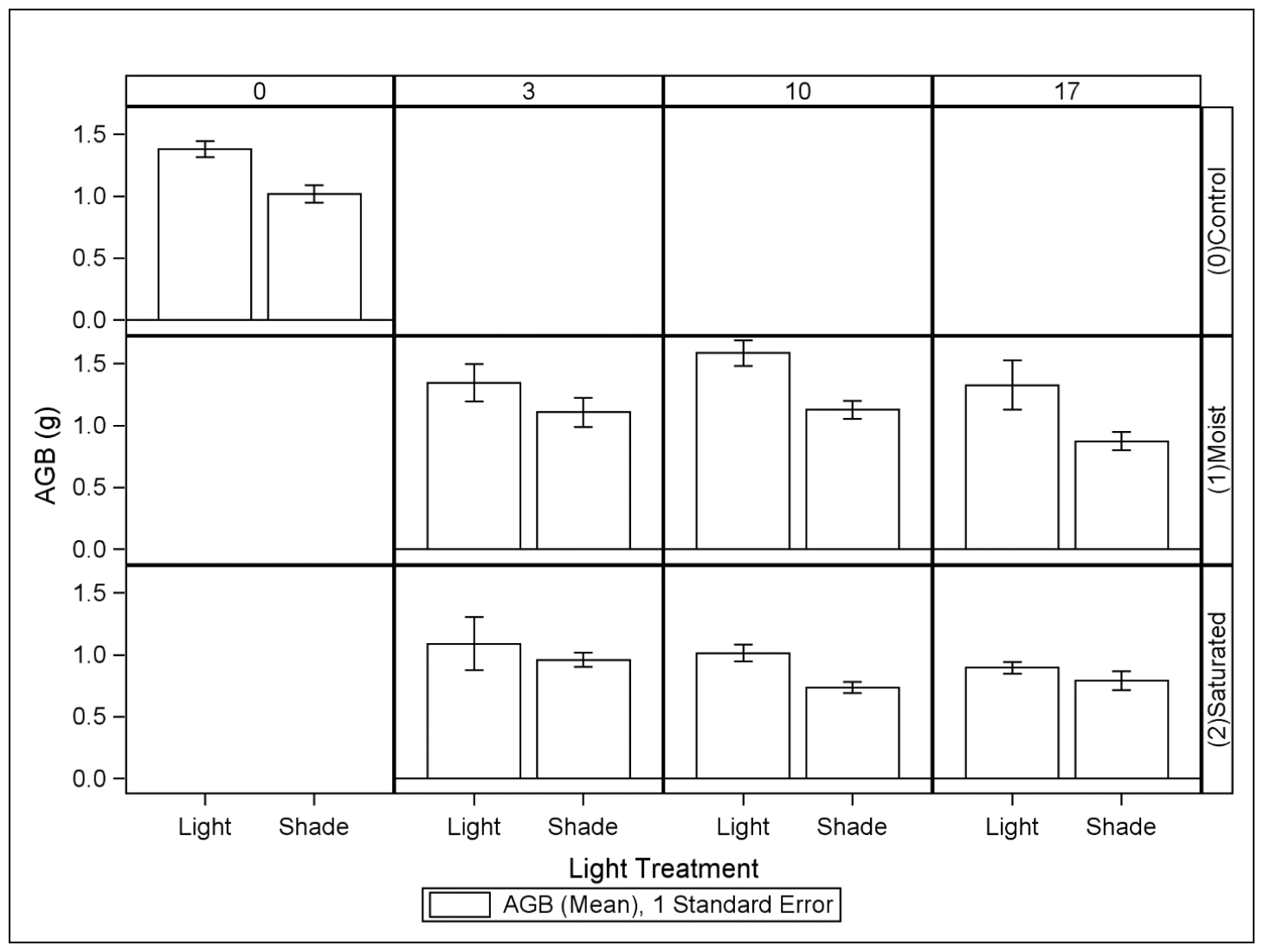

Figure 3-14. Mean aboveground biomass (AGB) for all combinations of light, flood depth and flood duration. "Light" and "Shade" treatments are 30\% shade and \%80 shade, respectively. Error bars are \pm 1 standard error. 


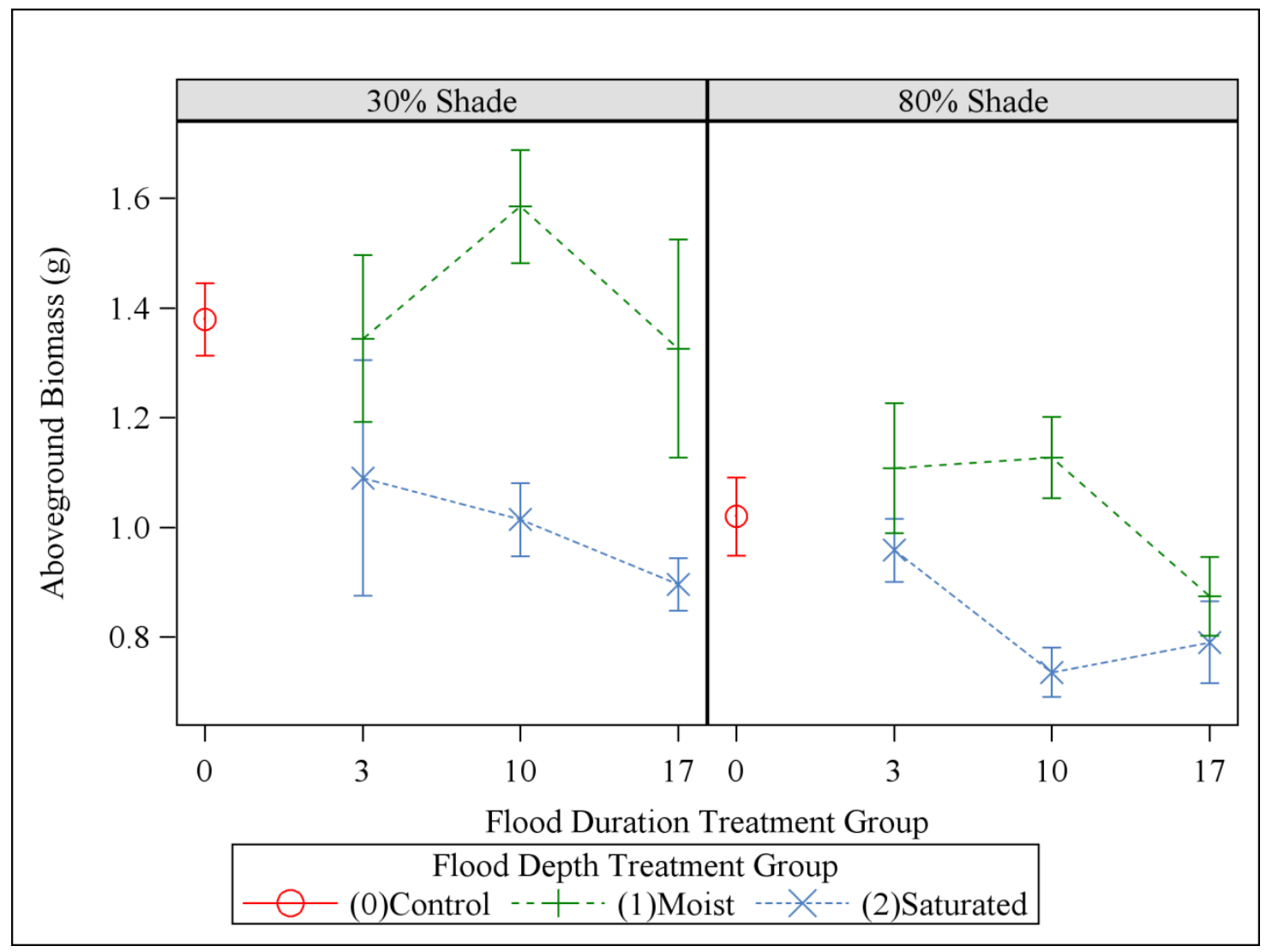

Figure 3-15. Interaction plot showing mean aboveground biomass for all combinations of light, flood depth and flood duration on Day 40, for surviving seedlings only. Error bars are \pm 1 standard error. 


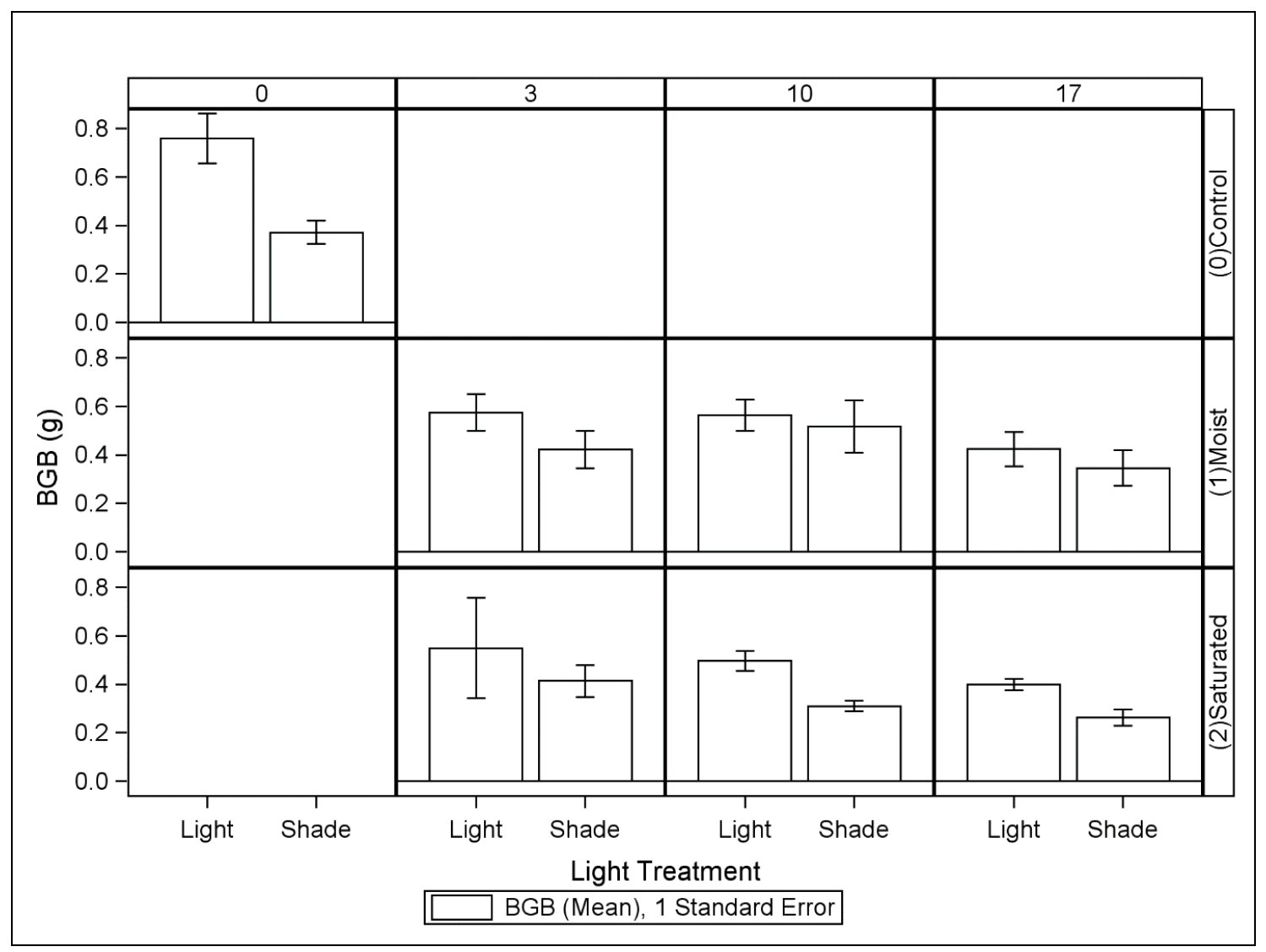

Figure 3-16. Mean belowground biomass (BGB) for all combinations of light, flood depth and flood duration, on Day 40 for surviving seedlings only. "Light" and "Shade" treatments are $30 \%$ shade and $80 \%$ shade, respectively. Error bars are \pm 1 standard error. 


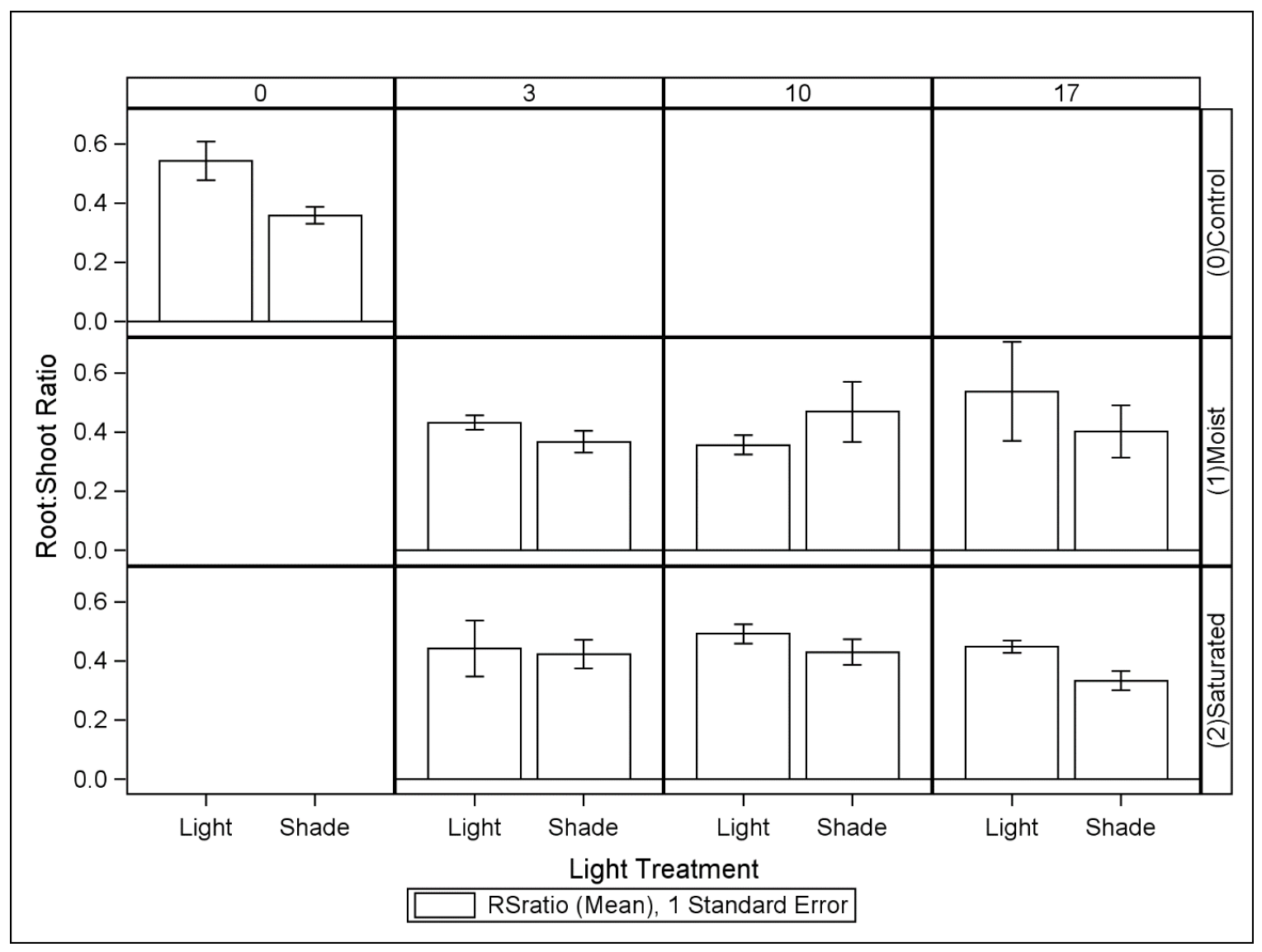

Figure 3-17. Mean root-shoot ratio (RSR) for all combinations of light, flood depth and flood duration on Day 40 for surviving seedlings only. "Light" and "Shade" treatments are $30 \%$ shade and $\% 80$ shade, respectively. Error bars are \pm 1 standard error. 


\section{CHAPTER IV}

\section{EFFECTS OF SIMULATED FLOODING ON GERMINATION OF LONICERA MAACKII SEEDS}

\section{$\underline{\text { Introduction }}$}

Gleasonian models of plant community development emphasize how species distributions are controlled by environmental gradients. Within this framework, the environmental sieve model describes how plant species distributions are limited by the availability of favorable abiotic conditions that may change through time and space (Vandervalk 1981). For instance, the anoxic stresses of wetland soils act as an ecological filter that limit successful seedling establishment to particular windows in time and space (Middleton 2000). To establish a successfully reproducing population in any habitat, a species must pass through this filter at each critical life stage.

Several recent studies, including the second chapter of this dissertation, show that the non-native invasive shrub species Lonicera maackii has an established presence in riparian, floodplain and bottomland hardwood forests in the United States (Predick and Turner 2008, Boyce et al. 2012, White 2014). Suitable habitat within these systems appears to be limited by the availability of drier, higher elevation sites (Swab et al. 2008). However, it is not known what life stages are most sensitive to the effects of flooding that limit the presence of L. maackii in bottomland hardwood forests. Because plant 
requirements and tolerances can change with ontogeny (Blood and Titus 2010), examining the role of biotic and abiotic stressors at multiple life stages is critical in delimiting the fundamental niche of plant species (Anderson et al. 2009).

Chapter III demonstrated that the growth of Lonicera maackii seedlings is negatively impacted by durations of saturation or inundation of 10 days or more. However, to some extent, they show the potential to survive and recover from the stresses of ephemeral saturated and inundated conditions. This chapter examines the potential of waterlogged conditions to impact another critical life history stage of L. maackii, seed germination.

Studies from upland systems show viable L. maackii seeds are dispersed by both birds (Bartuszevige and Gorchov 2006) and deer (Vellend 2002) . Undoubtedly, these dispersal mechanisms are also important in wetland systems, but the occurrence of this species in floodplains suggests hydrochory could be another means of dispersal. The fleshy red fruits of Lonicera maackii mature in late fall, and it is possible that they may be distributed onto floodplains during winter flooding in riparian systems. In depressional wetlands, seeds and fruits may be washed in from adjacent higher-elevation sites, or deposited through zoochory.

While some plants, such as Fraxinus pennsylvanica, have demonstrated the ability to germinate underwater (Schmiedel and Tackenberg 2013), many woody species rely on dispersal to higher elevation microsites, or drawdown, for successful germination in wetlands (Middleton 2000, Blood and Titus 2010). Seeds distributed by hydrochory are generally concentrated along drift lines in bottomland hardwood forests (Nilsson et al. 
2010). These features mark the interface between areas of inundation and higher elevation microsites. Dispersal into these areas is advantageous, as higher elevation microsites are generally more conducive to seed germination for most woody species (Middleton 2000). Thus, while the ability of seeds to germinate under flooded conditions is not generally a prerequisite to wetland establishment, it is advantageous for seeds to remain viable under waterlogged conditions. As a first step in understanding the degree to which flooding restricts the germination potential of Lonicera maackii, this study examines its potential seed germination under various flooding scenarios by quantifying the ability of Lonicera maackii seeds to germinate under various conditions of simulated flooding.

\section{$\underline{\text { Methods }}$}

The germination assay consisted of two consecutively applied manipulations intended to mimic different temporal flooding regimes, one during a seed stratification period and the other as a post-stratification event (or treatment). This transition was intended to mimic natural changes in hydrology that may occur in wetland soils (e.g. drawdown or flooding), and therefore assess the potential impact of these inundation fluctuations on L. maackii seed germination.

\section{Seed Sources and Viability Testing}

Seed material was obtained from L. maackii plants from a single wetland site in Jefferson County, Kentucky, USA. Mature fruits were collected on a single date in October 2011. These were briefly stored in a refrigerator for 2 days. Seeds were then separated from the fruit pulp in distilled water using a homemade macerator constructed 
by covering the blades of a conventional kitchen blender with rubber tubing. Recovered seeds were allowed to dry on paper towels until visibly dry (1-2 days), transferred to paper envelopes, and then placed in dry, cold storage in plastic containers until the beginning of the experiment.

Just prior to the initiation of the experiment (February 2012), samples of the stored seeds were tested for viability using a $1 \%$ tetrazolium (TZ) solution (10 seeds/Petri dish, $\mathrm{n}=5$ ) using established protocols for Lonicera spp. (Peters et al. 2000). Dissected seeds staining bright red throughout the embryo and endosperm were recorded as viable. Those not staining bright red throughout both seed parts were recorded as non-viable. Mean ( \pm S. D.) viability was $70.7 \pm 15.3 \%$. This method produces a conservative estimate of seed viability, as viable seeds with low vigor may not stain evenly throughout (Peters et al. 2000).

\section{Germination Assays}

The experiment was initiated on February 18, 2012 and lasted until May 23, 2012 (a total of 95 days). To minimize risk of microbial contamination all seeds were surface sterilized with a $1 \%$ sodium hypochlorite solution. Mean viability of surface sterilized seeds was estimated as $65.1 \pm 23.9 \%$ using the $\mathrm{TZ}$ test method discussed previously. Additionally, all plasticware, tools and media were autoclaved.

Some seeds of Lonicera maackii exhibit morphophysiological dormancy, requiring seeds to be subjected to a period of stratification under cold, moist conditions before germination is possible (Hidayati et al. 2000). Seeds were cold stratified under one of three conditions (moist, saturated or inundated sand), then transitioned to a 
different condition after stratification (also moist, saturated or inundated sand). A constantly moist and cool treatment was also included as a control and to serve as a reference simulating overwintering conditions in upland systems. Hereafter, these treatments are referred to as stratification treatments (i.e., the initial conditions in each treatment) and post-stratification treatments (e.g. treatment conditions after transition to different conditions), and are described in detail in the following sections. These transitions corresponded to either a flooding or drawdown event and were applied consecutively. The five treatments (indicating stratification to post-stratification transitions, respectively) were: moist control (no transition), moist-to-inundated transition, moist-to-saturated transition, saturated-to-moist transition and inundated-tomoist transition (Tab1e 4-1).

\section{Stratification Treatments}

Sixty $250 \mathrm{~mL}$ polypropylene containers were filled with $100 \mathrm{~g}$ of sterilized white aquarium sand to $1 \mathrm{~cm}$ depth, and randomly assigned to one of five treatment groups. According to Hidayati et al. (2000), stratification under light enhanced germination rates, and therefore each of the three refrigerator shelves was equipped with two single-strip 24" fluorescent lighting fixtures, controlled by a timer to provide 14 hours of light each day. Bulbs were 17 watts and provided light in the $7800 \mathrm{~K}$ spectrum. To minimize the effects of any vertical variation in lighting (variation among shelves), trays holding the polypropylene containers were made of opaque foam board that limited the transmission of light from one shelf to another. 
All containers were weighed before the addition of water. Replicates assigned moist stratification treatments received $15 \mathrm{~mL}$ of sterile distilled water, an amount sufficient to thoroughly wet the $100 \mathrm{~g}$ of substrate. Saturated treatments received $25 \mathrm{~mL}$ of water, raising the water level even with the sand surface. Inundated treatments received $80 \mathrm{~mL}$ of water, an amount sufficient to raise the water level $1 \mathrm{~cm}$ above the sand surface. These volumes of water were used as standards for moist, saturated and inundated conditions throughout the duration of the experiment. Thirty seeds were spaced evenly on the sand surface of each replicate container. Each container was sealed with a lid and weighed to the nearest $0.01 \mathrm{~g}$.

Containers were immediately transferred to a commercial refrigerator for a cold stratification period. Based on results from Hidayati et al. (2000), high germination rates greater than $90 \%$ were achieved after cold stratification at $5{ }^{\circ} \mathrm{C}$ with a 14 -hour photoperiod. Prior attempts to stabilize the refrigerator temperature at $5{ }^{\circ} \mathrm{C}$ revealed limitations in temperature control, and it was not possible to maintain an even, constant temperature throughout the unit. Data provided by temperature data loggers showed that temperature varied with both photoperiod (due to heat produced by the light fixtures) and vertically (due to the position of the condenser at the top of the unit). To minimize the differential effects of the vertical temperature gradient, trays holding the containers were rotated to a different shelf every 3 days (vertical rotation). Potential effects of horizontal variation in light levels (variation within a shelf) were minimized by rearranging replicates within a tray at each vertical shelf rotation. Rearrangement consisted of shifting replicates horizontally one position over, and rotating containers within each replicate one position front to back. 
Despite scheduled rotations, it was anticipated that germination of seeds would be somewhat asynchronous, due to the vertical temperature gradient. For instance, if sufficient stratification had occurred (or if stratification was unnecessary) seeds on warmer shelves for 3 days between rotations would likely germinate before those on cooler shelves. In order to statistically account for any variance in germination rate due to this factor, each shelf contained a single seed tray holding 3-4 complete replicate sets, and each tray was treated as an experimental block.

Temperature of the refrigeration unit was recorded hourly for the majority of the experimental duration using 2-3 temperature data loggers (Hobo Pro Series, Onset). Temperature was monitored from $3 / 2 / 12$ to $3 / 12 / 12$ on the bottom and middle shelves, and from $3 / 13 / 12$ to $3 / 25 / 12$ on the top and bottom shelves. From 3/26/12 to 5/23/12, temperature was recorded on all 3 shelves.

Seeds were examined every 2-3 days for signs of germination, defined as protrusion of the radicle $1 \mathrm{~mm}$ or greater. It was not anticipated that seeds would show significant germination during the low temperature stratification period. However, germination was first observed on 3/23/12, 34 days after initiation of stratification treatments. Attempts to delay germination by lowering the refrigerator temperature were made. Despite these efforts, germination continued at low temperatures and the decision was made to continue the post-stratification flooding or drawdown manipulations in the low-temperature environment. 


\section{Post-stratification treatments}

As in the stratification period, rotation of replicates within and between refrigerator shelves was carried out during post-stratification treatments. Poststratification treatments were begun on 3/27/12 (day 38) after initial germination of seeds was observed on 3/23/12. Treatments simulating transitions to flooded conditions (e.g. moist to saturated or moist to inundated transitions) received additional sterile distilled water. Saturated treatments received $15 \mathrm{~mL}$ to achieve saturated conditions $(\sim 25 \mathrm{~mL}$ total of water). Similarly, moist to inundated transitions received an additional $65 \mathrm{~mL}$ of water to achieve a total water volume of $80 \mathrm{~mL}$, the standard used here for inundated conditions. Because some evaporation occurred, the exact amount of water added was added by weight. The target weight of each treatment was determined by adding the amount of water by weight $(1 \mathrm{~mL}=1 \mathrm{~g})$ needed to transition moist treatments to either saturated or inundated conditions, based on initial container weights. The target mass was calculated for each container receiving water, and sterile distilled water was added until the target weight was achieved within a tolerance of $\pm 1 \mathrm{~g}$.

Simulating drawdown (e.g. saturated to moist or inundated to moist transition treatments) required the withdrawal of water from containers. Using an automatic pipette, all water that was possible to remove with a pipette was withdrawn. The accuracy of water removal in achieving intended water volumes was checked by comparing the target vs. actual container weights. The target mass of each container was

calculated by adding $10 \mathrm{~g}$ (the amount of water corresponding to moist conditions) to the initial dry container weight. The average difference from target weight was $5.2 \pm 0.31 \mathrm{~g}$ and 5.9 $\pm 1.4 \mathrm{~g}$ for saturated to moist and inundated to moist transitions, respectively. 
Once germination was observed, total numbers of germinating seeds in each dish were recorded every 3 days until 5/3/11 (75 days after beginning of stratification), when all containers had achieved at least 70\% germination (corresponding approximately to estimates of seed viability). During the incubation, seeds showing obvious signs of fungal colonization were removed to prevent further contamination. Seed germination for all samples between 5/14/11 (day 86) and 5/23/11 (day 95), revealed only a small number of new germinants gained between these two observation intervals (an average of less than 1 new germinant per dish), and the experiment was terminated.

\section{Data Analysis}

Mean germination time and germinability were calculated for each replicate container according to guidelines provided in Ranal and Garcia de Santana (2006). Mean germination time $(\bar{t})$ is a weighted mean of time to germination and was calculated as

$$
\bar{t}=\frac{\sum_{i=1}^{k} n_{i} t_{i}}{\sum_{i=1}^{k} n_{i}}
$$

where $t_{i}$ is the time (in days) when the $i^{t h}$ observation was made, $n_{i}$ is the number of seeds germinated in the interval between the $i^{\text {th }}$ observation and the previous observation and $k$ is the last day on which germination observations were made. Germinability was calculated as the total percentage of seeds germinated in each replicate by the end of the experiment.

A mixed linear model was used to test the effects of flooding treatment on mean germination time (MGT) and germinability using PROC MIXED in SAS 9.4. The 
experimental "seed tray" (e.g. the group of replicates comprising a single seed tray) was treated as a random effect, and modeled using the variance components (VC) method. Flooding treatment was treated as a main, fixed effect. Modeling "seed tray" as a random effect allowed the effects of flooding treatment on MGT or germinability to vary with seed tray. The justification to treat seed tray as a random effect was made based on the observation of initial asynchronous timing of germination between replicates on different trays. One tray began germination earlier than the other two, although the differences between the trays dissipated through time. The model used the restricted maximum likelihood (REML) estimation method. Germinability was modeled by converting the percentage to a decimal fraction and using the arcsine transform (commonly used for percentage data) where:

$$
\mathrm{Y}(\text { Transformed })=\operatorname{arcsine}\left(\mathrm{y}^{-2}\right)
$$

Model residuals were visually examined for normality and homoscedasticity. Significant differences in fixed effects at the $\mathrm{p}=0.05$ level were followed up with pairwise comparisons among treatment groups using the Tukey-Kramer method.

\section{$\underline{\text { Results }}$}

\section{Mean Germination Time}

The MGTs of all treatment groups ranged from 59.8 to 64.8 days and were longer than the moist control and the fixed effect of flooding treatment on MGT was significant ( $\mathrm{p}=0.012)$. Post-hoc pairwise comparison of flooding treatment groups using the TukeyKramer method showed a significant difference in MGT between the moist control and moist-to-inundated transition group $(\mathrm{p}=0.004)$. No other groups significantly differed 
from each other. The effect of "seed tray" modeled as a random effect, was not found to be significant $(\mathrm{p}=0.175)$.

\section{Germinability}

The mean germinability of all treatments was relatively high $(88.3 \pm 8.50 \%$ to $91.5 \pm 6.35 \%)$. The fixed effect of flooding treatment on total germinability was not significant $(\mathrm{p}=0.73)$. The mean germinability of treatments inundated during either stratification or post-stratification was lower than all others, but the difference was not statistically detectable.

\section{Environmental Variables: Temperature}

As expected, a vertical temperature gradient was observed during the experimental period. The difference in mean daily average temperatures between each shelf was approximately $2{ }^{\circ} \mathrm{C}$ (Table $4-1$ ), ranging from $2.3 \pm 0.5^{\circ} \mathrm{C}$ in the top shelf to $6.3 \pm 0.8{ }^{\circ} \mathrm{C}$ the bottom (Fig. $4-1$ ). The variation in mean daily temperature throughout the study period was close to the target temperature of $5^{\circ} \mathrm{C}-$ a stratification temperature that yielded high germination rates in Hidayati et al. (2000). A temperature adjustment to the refrigerator unit accounts for the temperature reduction seen on day 38 (see Methods). As seen in Fig. 4-1 temperature fluctuations became pronounced in the latter two-thirds of the experiment, possibly due to ambient temperature fluctuations in the surrounding laboratory,

\section{Discussion}

This study attempted to evaluate the potential effects of flooding stress on the germination of Lonicera maackii by mimicking natural hydrologic transitions in a 
controlled experiment. These transitions corresponded to either a flooding or drawdown event from different initial moisture conditions during cold stratification. A constantly moist treatment was also included as a reference mimicking winter moisture conditions in upland forested systems where flooding does not occur. Temperatures during the experiment were within the range observed in soils in winter and spring in our region (NRCS 2015).

A statistically significant effect of flooding treatments on mean germination time was detected. This significant effect was explained by longer mean germination times of treatments undergoing transitions from moist to flooded conditions compared to treatments experiencing consistently moist conditions. However, there was no difference in total germinability between any treatments, which was high under all treatments, indicating that seeds have the physiological potential, under aseptic conditions, to germinate even when flooded at low temperatures.

\section{Effects of Simulated Drawdown}

These findings show that the mean germination time and germinability of Lonicera maackii seeds cold-stratified under inundated conditions for approximately 30 days and transferred to moist conditions did not differ significantly from that of seeds incubated under constant moist conditions. This furthers the possibility that seeds deposited into flooded areas may retain viability and thus be able to germinate when more suitable conditions for growth (drawdown at the beginning of the growing season) occur. 
The ability of $L$. maackii seeds to remain viable under submersion also advances the possibility that hydrochory may be a secondary means of dispersal. Considering the origins of L. maackii from low-elevation and floodplain forests (Luken and Thieret 1996), it seems worth considering if its retention of viability under inundation and potential to germinate underwater is an adaptation to its native range and habitat. It should be noted that the ripe, fleshy fruits of $L$. maackii are not buoyant unless they have begun to dry (personal observation). Fruits ripening in the fall can be retained on the plant into January (Luken and Thieret 1996) and the high yield of fruit makes it likely that many seeds will fall to the forest floor (Luken and Goessling 1995). This timing of seed release would also match that of high flow conditions in floodplain systems, where L. maackii can be a dominant plant (White 2014). However, even if fruit characteristics do not encourage lateral dispersal via floodwaters, seeds could potentially be washed down from adjacent higher elevation areas and deposited in floodplains or microdepressions, where the ability to remain viable under prolonged submersion would be advantageous.

\section{Effects of Simulated Flooding}

Seeds subjected to a cold moist stratification followed by inundation germinated more slowly, but ultimately to similar percentages as all other treatments. Seeds used in this experiment did not germinate within 30 days, qualifying them as having either simple morphological dormancy (MD) or simple morphophysiological dormancy (MPD)

(Hidayati et al. 2000, Baskin and Baskin 2001). Seeds of L. maackii have underdeveloped embryos, which must elongate to break simple MD (Hidayati et al. 2000). It is possible that water-logging slows, but does not halt, biochemical processes 
that break MD requirements in L. maackii seeds. Although the water column was unlikely anaerobic in our experiment due to the initially sterile conditions, water still may limit the delivery of oxygen to developing plant embryos (Alani et al. 1985), thus retarding germination under field conditions.

The conditions for breaking dormancy in MPD seeds are more stringent. In addition to elongation of the embryo, seeds with MPD must also undergo physiological changes to break dormancy, and in L. maackii this is known to be accomplished by moist warm- or cold-stratification (Hidayati et al. 2000). It is unknown what percentage of seeds in this experiment had MD or MPD, thus it is not possible to know if seeds were able to break MPD requirements while inundated. Furthermore, since no treatments were consistently inundated, it is not possible to discern if consistently inundated conditions are sufficient to meet seed dormancy requirements and promote germination without a period of drawdown to moist conditions. However, since most woody plants do not establish in continuously flooded areas (Kozlowski 2002), it is unlikely that these would be areas of suitable habitat regardless. Finally, it is also possible that the somewhat underdeveloped dormancy mechanisms in L. maackii are insufficient to prevent germination in flooded conditions, even if these conditions are not optimal.

\section{Lab-to-Field Implications}

This study shows that L. maackii can germinate under saturated and inundated conditions, but only indicates the potential recruitment ability of L. maackii in flooded soils at low temperatures. The timing of germination in relation to seasonal hydrologic and climate changes is likely to restrict the establishment of new germinants. L. maackii 
seeds vary in their dormancy breaking requirements, and have been characterized as either having no dormancy (Luken and Goessling 1995), simple MD or simple MPD (Hidayati et al. 2000). L. maackii seeds with MPD need moist warm- or coldstratification, and are likely to germinate during this shrub's growing season, which in our region typically begins in the first week of March and ends in late November (Trammell et al. 2012 and personal observation). Freshly matured seeds with MD are capable of germinating in autumn after the embryo has elongated (Hidayati et al. 2000) and field observations from Luken and Thieret (1996) ) indicate that L. maackii seeds germinate year-round. The findings of this study show the potential for additional germination outside the growing season, as seeds germinated under mean daily temperatures from 2.3$6.3^{\circ} \mathrm{C}$.

To my knowledge, it has not been determined whether this ability to germinate at varied temperature is advantageous, or increases the risk of seedling mortality. If germination of seedlings under flooded conditions is not matched closely with drawdown, this may ultimately contribute to mortality. This study demonstrated the potential of L. maackii to germinate soon after being transferred from cold/moist to cold/inundated conditions--environmental cues that signify the arrival of winter floods and may not be conducive to the survival of newly germinated seeds. Recently germinated seeds subjected to the pressure of winter flooding must contend with lowoxygen stress, water sheer stress, burial by sedimentation, as well as low/freezing temperatures. Additionally, small seedlings may not have developed the root systems sufficient for tolerating harsh winter conditions. Although soft tissues of adult plants have been shown to tolerate episodes of freezing temperatures (McEwan et al. 2009), the 
resilience of young seedlings, to my knowledge, has not been studied. Therefore, it is unknown whether seedlings established in autumn or winter contribute significantly to $L$. maackii recruitment in either upland or wetland habitats. Because seeds began germinating after only a month, it was not possible to evaluate the potential of L. maackii seeds to remain viable and germinate after several months of flooding — as could occur with winter floods. It is possible that more consistent and/or lower temperatures would have stalled the germination of seeds, allowing evaluation of viability under longer flooding scenarios. However, the temperatures in this study were within the bounds of the normal monthly winter temperatures experienced over a significant portion of $L$. maackii's invasion range in the United States, and thus may accurately reflect the winter and early spring germination potential of L. maackii in these areas (NRCS 2015).

Vulnerability to microbes under field conditions is another variable not evaluated by this study, and a factor that is likely to impact the germinability and mortality of seeds in the field. Relative susceptibility of seeds to infection under flooded as opposed to upland conditions would also need to be evaluated. Orrock et al. (2012) found that $L$. maackii was more susceptible to seed mortality due to fungal pathogens than two native shrub species. Blaney and Kotanen (2001) buried seeds of upland non-native and native species in wetland and upland soils, and then assessed the germination potential of these seeds in a greenhouse under moist conditions. The germination of seeds buried in wetland soils was lower than those in upland soils, and the number of seeds germinated increased when fungicide was applied, implicating greater seed loss due to fungal infection. Thus, fungal activity was implicated in explaining high seed mortality in wetland soils, and it was suggested that this might be one mechanism by which upland 
species are excluded from wetland areas. Studies in tropical forests also provide evidence for greater activity of soil plant pathogens with increasing soil moisture (Augspurger 1983, Augspurger and Kelly 1984). Certainly, the longer germination time under flooded conditions would increase the probability of seeds being lost to microbial infection. Based on these findings, it is reasonable to suspect that the high germinability of seeds under sterile, inundated conditions in this experiment may overestimate germinability in the field.

\section{Conclusions}

Previous studies have shown that the presence of Lonicera maackii is restricted to higher elevation areas in bottomland hardwood forests. This study examined the potential of flooding — during or after cold stratification - to serve as an ecological filter limiting the passage of $L$. maackii past the seed stage in these environments. Mean germination time, but not germinability, differed significantly between moist controls and treatments simulating moist to inundated transitions. Seeds subjected to inundated or saturated conditions during the stratification period and followed by simulated drawdown had mean germination times and germinability similar to moist controls. This finding advances the possibility that seeds of L. maackii seeds can remain viable in flooded areas, and germinate successfully after drawdown. These results also suggest that temporary, winter flooding of wetland microsites may not impose a major limitation on L. maackii germination. 


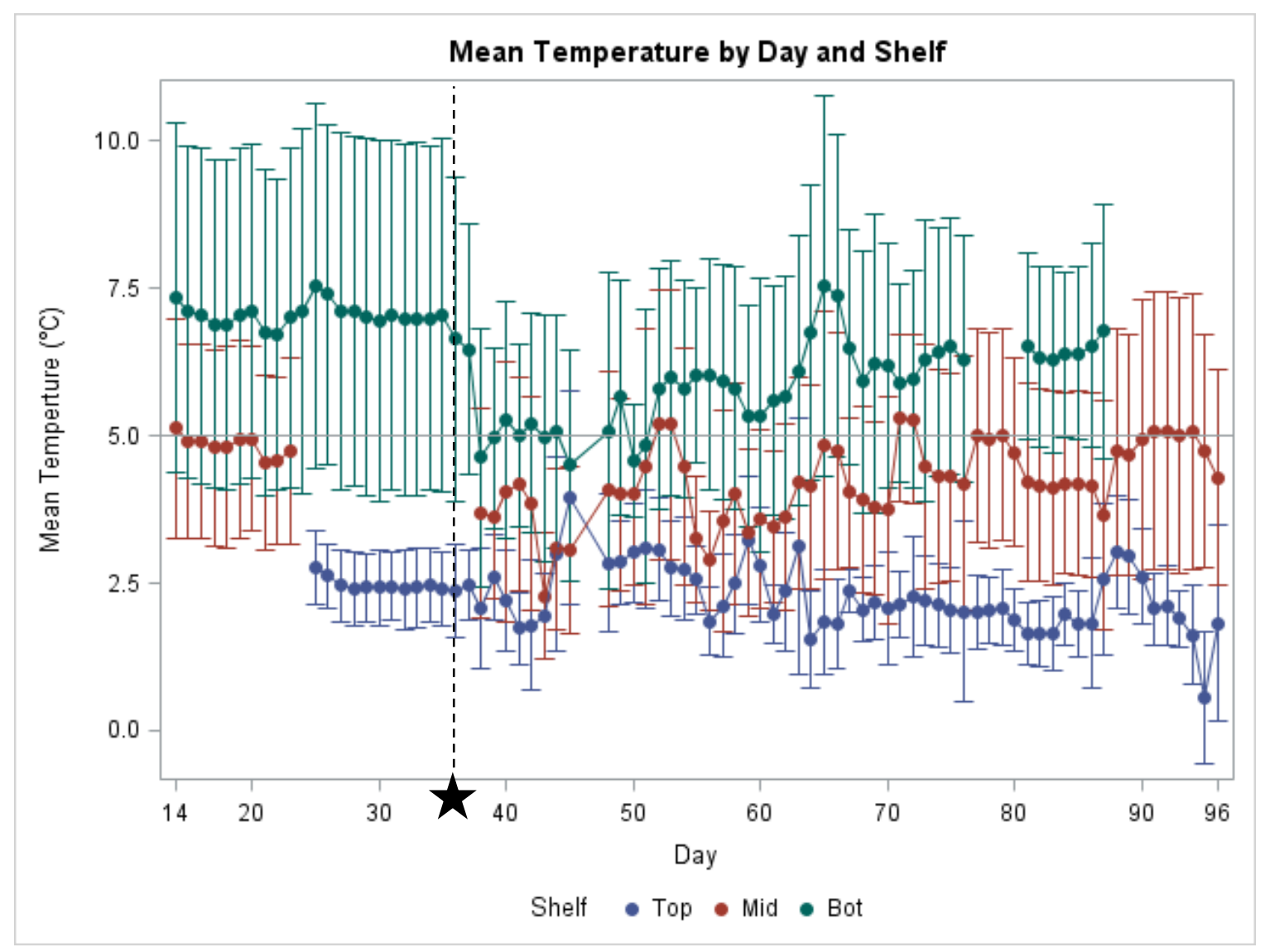

Figure 4-1. Mean daily temperature in experimental chamber (refrigerator) from days 14-96. Error bars indicate \pm 1 S.D. The horizontal line indicates $5{ }^{\circ} \mathrm{C}$. Breaks in graph lines indicate missing data. The black star indicates when germination was first noted at day 34. On Day 38 the temperature in the unit was reduced purposely so that bottom shelf could be closer to the target temperature of $5^{\circ} \mathrm{C}$. Trays containing seed plates were rotated between shelves as described in Methods. 
Table 4-1. Summary of stratification and post-stratification treatments for all five treatment groups in germination assay.

\begin{tabular}{ccc}
\hline \hline $\begin{array}{c}\text { Stratification } \\
\text { Treatment }\end{array}$ & $\begin{array}{c}\text { Post-Stratification } \\
\text { Treatment }\end{array}$ & $\begin{array}{c}\text { Transition simulates } \\
\text { flooding/drawdown? }\end{array}$ \\
\hline Moist & Moist & No flooding (control) \\
Moist & Inundated & Flooding \\
Moist & Saturated & Flooding \\
Inundated & Moist & Drawdown \\
Saturated & Moist & Drawdown \\
\hline \hline
\end{tabular}


Table 4-2. Means of mean germination time (MGT) for all flooding treatments and moist controls. Means with different letters indicate a significant difference $p \leq 0.05$ between treatments according to the Tukey-Kramer test.

\begin{tabular}{cccccc}
\hline \hline $\begin{array}{c}\text { Flooding } \\
\text { Treatment }\end{array}$ & $\mathrm{n}$ & $\begin{array}{c}\text { Mean Germination } \\
\text { Time } \\
(\text { days) }\end{array}$ & $\begin{array}{c}\text { Std. } \\
\text { Dev }\end{array}$ & Minimum & Maximum \\
\hline Control (Moist) & 20 & $59.8^{\mathrm{ac}}$ & 4.04 & 51.8 & 67.3 \\
Inundated $\rightarrow$ Moist & 10 & $62.1^{\mathrm{b}}$ & 3.57 & 55.1 & 67.5 \\
Moist $\rightarrow$ Inundated & 10 & $64.8^{\mathrm{ab}}$ & 5.87 & 56.4 & 73.8 \\
Moist $\rightarrow$ Saturated & 10 & $61.5^{\mathrm{ab}}$ & 4.10 & 55.6 & 68.6 \\
Saturated $\rightarrow$ Moist & 10 & $61.3^{\mathrm{ab}}$ & 3.90 & 53.5 & 66.4 \\
\hline \hline
\end{tabular}


Table 4-3. Means of total seed germinability of flooding treatments (as a percentage). Global tests of fixed effects show no significant difference between groups. Values for $n$ indicate the number of containers per treatment. Minimum and maximum values correspond to the minimum and maximum values of germinability observed among $n$ containers in each flooding treatment group.

\begin{tabular}{cccccc}
\hline \hline Flooding Treatment & $n$ & Germinability & Std. Dev & Minimum & Maximum \\
\hline Control (Moist) & 20 & 91.5 & 6.4 & 80.0 & 100.0 \\
Inundated $\rightarrow$ Moist & 10 & 88.3 & 8.5 & 76.7 & 100.0 \\
Moist $\rightarrow$ Inundated & 10 & 88.7 & 7.6 & 70.0 & 96.7 \\
Moist $\rightarrow$ Saturated & 10 & 90.7 & 3.8 & 83.3 & 96.7 \\
Saturated $\rightarrow$ Moist & 10 & 90.0 & 7.5 & 76.7 & 100.0 \\
\hline \hline
\end{tabular}




\section{REFERENCES}

Alani, A., F. Bruzau, P. Raymond, V. Saintges, J. M. Leblanc, and A. Pradet. 1985. Germination, Respiration, and Adenylate Energy-Charge of Seeds at Various Oxygen Partial Pressures. Plant Physiology 79:885-890.

Anderson, H. M., M. R. Gale, M. F. Jurgensen, and C. C. Trettin. 2007. Vascular and non-vascular plant community response to silvicultural practices and resultant microtopography creation in a forested wetland. Wetlands 27:68-79.

Anderson, J. T., A. A. Landi, and P. L. Marks. 2009. Limited flooding tolerance of juveniles restricts the distribution of adults in an understory shrub (Itea virginica; Iteaceae). American Journal of Botany 96:1603-1611.

Arguez, A., I. Durre, S. Applequist, M. Squires, R. Vose, X. Yin, and R. Bilotta. 2010. U.S. Climate Normals (1981-2010) for Louisville International Airport. National Climatic Data Center, National Oceanic and Atmospheric Administration. Retrieved from http://www.ncdc.noaa.gov/cdo-web/datatools/normals

Augspurger, C. K. 1983. Seed dispersal of the tropical tree, Platypodium elegans, and the escape of its seedlings from fungal pathogens. Journal of Ecology 71:759-771.

Augspurger, C. K., and C. K. Kelly. 1984. Pathogen mortality of tropical tree seedlings experimental studies of the effects of dispersal distance, seedling density, and light conditions. Oecologia 61:211-217.

Bartuszevige, A. M., and D. L. Gorchov. 2006. Avian seed dispersal of an invasive shrub. Biological Invasions 8:1013-1022.

Bartuszevige, A. M., D. L. Gorchov, and L. Raab. 2006. The relative importance of landscape and community features in the invasion of an exotic shrub in a fragmented landscape. Ecography 29:213-222.

Baskin, C. C., and J. M. Baskin. 2001. Seeds: ecology, biogeography, and evolution of dormancy and germination. Elsevier.

Battaglia, L. L., S. A. Fore, and R. R. Sharitz. 2000. Seedling emergence, survival and size in relation to light and water availability in two bottomland hardwood species. Journal of Ecology 88:1041-1050. 
Blaney, C. S., and P. M. Kotanen. 2001. Effects of fungal pathogens on seeds of native and exotic plants: a test using congeneric pairs. Journal of Applied Ecology 38:1104-1113.

Blood, L. E., and J. H. Titus. 2010. Microsite effects on forest regeneration in a bottomland swamp in western New York. Journal of the Torrey Botanical Society 137:88-102.

Bolund, P., and S. Hunhammar. 1999. Ecosystem services in urban areas. Ecological Economics 29:293-301.

Borgmann, K. L., and A. D. Rodewald. 2005. Forest restoration in urbanizing landscapes: Interactions between land uses and exotic shrubs. Restoration Ecology 13:334340.

Boyce, R. L., R. D. Durtsche, and S. L. Fugal. 2012. Impact of the invasive shrub Lonicera maackii on stand transpiration and ecosystem hydrology in a wetland forest. Biological Invasions 14:671-680.

Brothers, T. S., and A. Spingarn. 1992. Forest Fragmentation and Alien Plant Invasion of Central Indiana Old-Growth Forests. Conservation Biology 6:91-100.

Burns, R. M., and B. H. Honkala. 1990. Silvics of North America: Volume 2. Hardwoods. Agriculture Handbook 654. United States Department of Agriculture.

Carreiro, M. M., and C. E. Tripler. 2005. Forest remnants along urban-rural gradients: Examining their potential for global change research. Ecosystems 8:568-582.

Cadenasso, M. L., and S. T. A. Pickett. 2000. Linking forest edge structure to edge function: mediation of herbivore damage. Journal of Ecology 88:31-44.

Cadenasso, M. L., and S. T. A. Pickett. 2001. Effect of edge structure on the flux of species into forest interiors. Conservation Biology 15:91-97.

Chen, J. Q., J. F. Franklin, and T. A. Spies. 1992. Vegetation Responses to Edge Environments in Old-Growth Douglas-Fir Forests. Ecological Applications 2:387396.

Chen, J. Q., J. F. Franklin, and T. A. Spies. 1995. Growing-Season Microclimatic Gradients From Clear-Cut Edges Into Old-Growth Douglas-Fir Forests. Ecological Applications 5:74-86.

Costanza, R., R. d'Arge, R. de Groot, S. Farber, M. Grasso, B. Hannon, K. Limburg, S. Naeem, R. V. O'Neill, J. Paruelo, R. G. Raskin, P. Sutton, and M. van den Belt. 
1997. The value of the world's ecosystem services and natural capital. Nature 387:253-260.

Dahl, T. E. 2016. Status and trends of wetlands in the conterminous United States 2004 to 2009. U.S. Department of the Interior, Washington, D.C.

Delgado, J. D., N. L. Arroyo, J. R. Arevalo, and J. M. Fernandez-Palacios. 2007. Edge effects of roads on temperature, light, canopy cover, and canopy height in laurel and pine forests (Tenerife, Canary Islands). Landscape and Urban Planning 81:328-340.

Ens, E. J., and K. French. 2008. Exotic woody invader limits the recruitment of three indigenous plant species. Biological Conservation 141:590-595.

Faulkner, S. 2004. Urbanization impacts on the structure and function of forested wetlands. Urban Ecosystems 7:89-106.

Field, C. B. et al. 2007. Climate Change 2007: Impacts, Adaptation and Vulnerability. North America. Pages 617-652. Cambridge University Press, New York.

USFWS (U.S. Fish and Wildlife Service). 2009. National Wetlands Inventory. Retrieved 1/1/2009. Available online at https://www.fws.gov/wetlands/Data/Mapper.html

Gayek, A., and M. F. Quigley. 2001. Does topography affect the colonization of Lonicera maackii and Ligustrum vulgare in a forested glen in southwestern Ohio? Ohio Journal of Science 101:95-100.

Grubb, P.J., 1977. The maintenance of species-richness in plant communities: the importance of the regeneration niche. Biological Reviews 52(1):107-145.

Harper, J.L., 1977. Population biology of plants. Academic Press.

Harper, K. A., S. E. Macdonald, P. J. Burton, J. Chen, K. D. Brosofske, S. C. Saunders, E. S. Euskirchen, D. Roberts, M. S. Jaiteh, and P. A. Esseen. 2005. Edge influence on forest structure and composition in fragmented landscapes. Conservation Biology 19:768-782.

Hartman, K. M., and B. C. McCarthy. 2008. Changes in forest structure and species composition following invasion by a non-indigenous shrub, Amur honeysuckle (Lonicera maackii). Journal of the Torrey Botanical Society 135:245-259.

Hasanuzzaman, M., K. Nahar, M. M. Alam, R. Roychowdhury, and M. Fujita. 2013. Physiological, biochemical, and molecular mechanisms of heat stress tolerance in plants. International Journal of Molecular Sciences 14:9643-9684. 
Hidayati, S. N., J. M. Baskin, and C. C. Baskin. 2000. Dormancy-breaking and germination requirements of seeds of four Lonicera species (Caprifoliaceae) with underdeveloped spatulate embryos. Seed Science Research 10:459-469.

Honnay, O., K. Verheyen, and M. Hermy. 2002. Permeability of ancient forest edges for weedy plant species invasion. Forest Ecology and Management 161:109-122.

Hutchinson, T. F., and J. L. Vankat. 1997. Invasibility and effects of Amur honeysuckle in southwestern Ohio forests. Conservation Biology 11:1117-1124.

Jackson, R. B., S. R. Carpenter, C. N. Dahm, D. M. McKnight, R. J. Naiman, S. L. Postel, and S. W. Running. 2001. Water in a changing world. Ecological Applications 11:1027-1045.

Jules, E. S., and B. J. Rathcke. 1999. Mechanisms of reduced Trillium recruitment along edges of old-growth forest fragments. Conservation Biology 13:784-793.

Kangas, L. C., R. Schwartz, M. R. Pennington, C. R. Webster, and R. A. Chimner. 2016. Artificial microtopography and herbivory protection facilitates wetland tree (Thuja occidentalis L.) survival and growth in created wetlands. New Forests 47:73-86.

Kozlowski, T. T. 2002. Physiological-ecological impacts of flooding on riparian forest ecosystems. Wetlands 22:550-561.

LI-COR. 1992. LAI 2000 Plant Canopy Analyzer. Instruction Manual. LI-COR, Lincoln, Nebraska.

Luken, J. O., and N. Goessling. 1995. Seedling Distribution and Potential Persistence of the Exotic Shrub Lonicera maackii in Fragmented Forests. American Midland Naturalist 133:124-130.

Luken, J. O., L. M. Kuddes, T. C. Tholemeier, and D. M. Haller. 1997. Comparative responses of Lonicera maackii (Amur honeysuckle) and Lindera benzoin (spicebush) to increased light. American Midland Naturalist 138:331-343.

Luken, J. O., and J. W. Thieret. 1996. Amur honeysuckle, its fall from grace. Bioscience $46: 18-24$

Luken, J. O., T. C. Tholemeier, L. M. Kuddes, and B. A. Kunkel. 1995. Performance, plasticity, and acclimation of the nonindigenous shrub Lonicera maackii (Caprifoliaceae) in contrasting light environments. Canadian Journal of BotanyRevue Canadienne De Botanique 73:1953-1961.

Magurran, A. E. 2013. Ecological diversity and its measurement. Springer Science \& Business Media. 
Matlack, G. R. 1993. Microenvironment Variation Within and Among Forest Edge Sites in the Eastern United States. Biological Conservation 66:185-194.

Matlack, G. R. 1994. Vegetation Dynamics of the Forest Edge: Trends in Space and Successional Time. Journal of Ecology 82:113-123.

McCune, B., J. B. Grace, and D. L. Urban. 2002. Analysis of ecological communities. MjM Software Design. Gleneden Beach, Oregon.

McEwan, R. W., M. K. Birchfield, A. Schoergendorfer, and M. A. Arthur. 2009. Leaf phenology and freeze tolerance of the invasive shrub Amur honeysuckle and potential native competitors. Journal of the Torrey Botanical Society 136:212220.

Medley, K. E., M. J. McDonnell, and S. T. Pickett. 1995. Forest-Landscape Structure along an Urban-To-Rural Gradient. The Professional Geographer 47:159-168.

Middleton, B. 2000. Hydrochory, seed banks, and regeneration dynamics along the landscape boundaries of a forested wetland. Plant Ecology 146:169-184.

Mills, J. E., J. A. Reinartz, G. A. Meyer, and E. B. Young. 2009. Exotic shrub invasion in an undisturbed wetland has little community-level effect over a 15-year period. Biological Invasions 11:1803-1820.

Mitsch, W. J. 2000. Biological Adaptations to the Wetland Environment. Wetlands. John Wiley and Sons, Inc., New York.

Mitsch, W. J., and J. G. Gosselink. 2007. Wetlands, 4th edition. J. Wiley \& Sons, Inc.

Moran, M. A. 1984. Influence of adjacent land use on understory vegetation of New York forests. Urban Ecology 8:329-340.

MSD. 2006. Wet Weather and Water Quality Program, Pond Creek Watershed. Louisville Metropolitan Sewer District.

MSD (Metropolitan Sewer District). 2010. Stormwater Master Plan. Retrieved 4/12/16 from http://www.msdlouky.org/programs/crssite/SMMP/WATERSHED\%20 MASTER \%20PLAN.pdf

NCEI (National Centers for Environmental Information). 2016. U.S. Climatological Rankings, 1895-2016. National Oceanic and Atmospheric Administration. Retrieved from https://www.ncdc.noaa.gov/temp-and-precip/climatologicalrankings 
Nilsson, C., R. L. Brown, R. Jansson, and D. M. Merritt. 2010. The role of hydrochory in structuring riparian and wetland vegetation. Biological Reviews 85:837-858.

NRCS (Natural Resource Conservation Service). 1999. Soil Taxonomy: A Basic System of Soil Classification for Making and Interpreting Soil Surveys. Second Edition. United States Department of Agriculture. Available at http://www.nrcs.usda.gov /Internet/ FSE_DOCUMENTS/nrcs142p2_051232.pdf

NRCS (Natural Resource Conservation Service). 2005. Soil Survey of Jefferson County, Kentucky. United States Department of Agriculture. Available at http://www.nrcs.usda.gov/Internet/FSE_MANUSCRIPTS/kentucky/ KY111/0/Jefferson_KY.pdf

NRCS (Natural Resource Conservation Service). 2015. Soil Climate Analysis Dataset. U.S. Department of Agriculture. Available at http://www.wcc.nrcs.usda.gov/scan

NRCS (Natural Resource Conservation Service). 2016. USDA Plants Database. United States Department of Agriculture. Available at from http://plants.usda.gov/

Orrock, J. L., C. C. Christopher, and H. P. Dutra. 2012. Seed bank survival of an invasive species, but not of two native species, declines with invasion. Oecologia 168:1103-1110.

Pauchard, A., and P. B. Alaback. 2004. Influence of elevation, land use, and landscape context on patterns of alien plant invasions along roadsides in protected areas of south-central Chile. Conservation Biology 18:238-248.

Pennington, D. N., J. R. Hansel, and D. L. Gorchov. 2010. Urbanization and riparian forest woody communities: Diversity, composition, and structure within a metropolitan landscape. Biological Conservation 143:182-194.

Peters, J., B. Lanham, Association of Official Seed Analysts, and T. T. Committee. 2000. Tetrazolium testing handbook : contribution no. 29 to the Handbook on seed testing. The Association of Official Seed Analysts, Lincoln, Nebraska.

Peterson, C. J. 2000. Catastrophic wind damage to North American forests and the potential impact of climate change. Science of the Total Environment 262:287311.

Pietrzykowski, M., W. L. Daniels, and S. C. Koropchak. 2015. Microtopographic effects on growth of young bald cypress (Taxodium distichum L.) in a created freshwater forested wetland in southeastern Virginia. Ecological Engineering 83:135-143.

Poland, T. M., and D. G. McCullough. 2006. Emerald ash borer: Invasion of the urban forest and the threat to North America's ash resource. Journal of Forestry 104:118-124. 
Predick, K. I., and M. G. Turner. 2008. Landscape configuration and flood frequency influence invasive shrubs in floodplain forests of the Wisconsin River (USA). Journal of Ecology 96:91-102.

Ranal, M. A., and D. Garcia de Santana. 2006. How and why to measure the germination process? Revista Brasil Botanica 29:1-11.

Robertson, A.I., Bacon, P. and Heagney, G. 2001. The responses of floodplain primary production to flood frequency and timing. Journal of Applied Ecology 38: 126136.

Saunders, D. A., R. J. Hobbs, and C. R. Margules. 1991. Biological Consequences of Ecosystem Fragmentation - A Review. Conservation Biology 5:18-32.

Schmiedel, D., and O. Tackenberg. 2013. Hydrochory and water induced germination enhance invasion of Fraxinus pennsylvanica. Forest Ecology and Management 304:437-443.

Schmitt, C. B., N. D. Burgess, L. Coad, A. Belokurov, C. Besancon, L. Boisrobert, A. Campbell, L. Fish, D. Gliddon, K. Humphries, V. Kapos, C. Loucks, I. Lysenko, L. Miles, C. Mills, S. Minnemeyer, T. Pistorius, C. Ravilious, M. Steininger, and G. Winkel. 2009. Global analysis of the protection status of the world's forests. Biological Conservation 142:2122-2130.

Soil Survey Staff, Natural Resources Conservation Service, United States Department of Agriculture. Soil Survey Geographic (SSURGO) Database for Jefferson County, Kentucky. Retrieved 01/01/2009 from http://www.nrcs.usda.gov/wps/portal/nrcs/soilsurvey/soils/survey/state/

Sprecher, S. W. 2008. Installing monitoring wells in soils (Version 1.0). National Soil Survey Center, Natural Resources Conservation Service, U.S. Department of Agriculture, Lincoln, Nebraska.

Swab, R. M., L. Zhang, and W. J. Mitsch. 2008. Effect of hydrologic restoration and Lonicera maackii removal on herbaceous understory vegetation in a bottomland hardwood forest. Restoration Ecology 16:453-463.

USFS (United States Forest Service). 2007. Emerald ash borer research and development meeting. V. Mastro, D. Lance, R. Reardon, and G. Parra, editors. U.S. Department of Agriculture.

Vandervalk, A. G. 1981. Succession In Wetlands - A Gleasonian Approach. Ecology 62:688-696. 
Vellend, M. 2002. A pest and an invader: White-tailed deer (Odocoileus virginianus Zimm.) as a seed dispersal agent for honeysuckle shrubs (Lonicera L.). Natural Areas Journal 22:230-234.

Weathers, K. C., M. L. Cadenasso, and S. T. Pickett. 2001. Forest edges as nutrient and pollutant concentrators: potential synergisms between fragmentation, forest canopies, and the atmosphere. Conservation Biology 15:1506-1514.

White, R. J. C., Margaret M.; Zipperer, Wayne C. 2014. Woody plant communities along urban, suburban, and rural streams in Louisville, Kentucky, USA. Urban Ecosystems, 17:1-36

With, K. A. 2002. The landscape ecology of invasive spread. Conservation Biology 16:1192-1203.

Zedler, J. B., and S. Kercher. 2004. Causes and consequences of invasive plants in wetlands: Opportunities, opportunists, and outcomes. Critical Reviews in Plant Sciences 23:431-452.

Zedler, J. B., and S. Kercher. 2005. Wetland resources: Status, trends, ecosystem services, and restorability. Pages 39-74 Annual Review of Environment and Resources. 
Appendix Table 1. Summary of all environmental variables measured for all sites.

\begin{tabular}{|c|c|c|c|c|c|c|c|c|c|c|c|c|c|}
\hline \multirow{2}{*}{$\begin{array}{c}\text { Site } \\
1\end{array}$} & \multirow{2}{*}{$\begin{array}{c}\begin{array}{c}\text { Per. } \\
\text { Transect }\end{array} \\
\text { N1 }\end{array}$} & \multirow{2}{*}{$\begin{array}{c}\text { Parallel } \\
\text { Transect } \\
1\end{array}$} & \multicolumn{2}{|c|}{$\begin{array}{c}\% \text { Herb } \\
\text { Cover } \\
\pm \mathrm{SE}\end{array}$} & \multicolumn{2}{|c|}{$\begin{array}{c}\% \text { Bare } \\
\text { Soil } \\
\pm \mathrm{SE}\end{array}$} & \multicolumn{2}{|c|}{$\begin{array}{c}\text { Leaf } \\
\text { Litter } \\
\pm \mathrm{SE}\end{array}$} & \multicolumn{2}{|c|}{$\begin{array}{c}\% \text { CWD } \\
\pm \mathrm{SE}\end{array}$} & \multicolumn{2}{|c|}{$\begin{array}{c}\text { \% Canopy } \\
\text { Closure } \\
\pm \text { SE }\end{array}$} & \multirow{2}{*}{$\begin{array}{l}\text { 'LAI } \\
5.23\end{array}$} \\
\hline & & & 14 & 8 & 32 & 6 & 68 & 6 & 3 & 3 & 90 & 1 & \\
\hline 1 & N1 & 5 & 11 & 9 & 6 & 3 & 74 & 24 & 2 & 1 & 84 & 2 & 4.32 \\
\hline 1 & N1 & 10 & 18 & 15 & 3 & 0 & 98 & 0 & 9 & 8 & 87 & 3 & 4.4 \\
\hline 1 & N1 & 30 & 3 & 0 & 3 & 0 & 98 & 0 & 0 & 0 & 90 & 3 & 4.59 \\
\hline 1 & N1 & 60 & 6 & 3 & 49 & 12 & 39 & 14 & 0 & 0 & 89 & 2 & 4.44 \\
\hline 1 & $\mathrm{~N} 2$ & 1 & 9 & 4 & 6 & 3 & 79 & 6 & 28 & 3 & 87 & 1 & 4.92 \\
\hline 1 & $\mathrm{~N} 2$ & 5 & 6 & 3 & 74 & 6 & 26 & 6 & 7 & 3 & 86 & 2 & 4.62 \\
\hline 1 & N2 & 10 & 14 & 8 & 79 & 6 & 21 & 6 & 3 & 2 & 87 & 2 & 4.85 \\
\hline 1 & N2 & 30 & 23 & 9 & 14 & 8 & 83 & 7 & 2 & 1 & 76 & 6 & 4.23 \\
\hline 1 & $\mathrm{~N} 2$ & 60 & 26 & 6 & 3 & 0 & 94 & 3 & 4 & 2 & 88 & 2 & 4.49 \\
\hline 1 & S1 & 1 & 32 & 6 & 9 & 4 & 91 & 4 & 3 & 2 & 92 & 2 & 3.83 \\
\hline 1 & S1 & 5 & 18 & 7 & 3 & 0 & 91 & 4 & 1 & 1 & 90 & 2 & 3.75 \\
\hline 1 & S1 & 10 & 56 & 18 & 6 & 3 & 94 & 3 & 1 & 1 & 93 & 1 & 4.08 \\
\hline 1 & S1 & 30 & 3 & 0 & 3 & 0 & 94 & 3 & 1 & 1 & 92 & 2 & 4.58 \\
\hline 1 & S1 & 60 & 3 & 0 & 85 & 0 & 15 & 0 & 0 & 0 & 93 & 2 & 4.23 \\
\hline 1 & S2 & 1 & 3 & 0 & 3 & 0 & 91 & 4 & 1 & 0 & 92 & 1 & 4.76 \\
\hline 1 & S2 & 5 & 6 & 3 & 23 & 9 & 74 & 6 & 2 & 2 & 91 & 3 & 4.31 \\
\hline 1 & S2 & 10 & 3 & 0 & 18 & 7 & 71 & 13 & 0 & 0 & 93 & 3 & 4.43 \\
\hline 1 & S2 & 30 & 6 & 3 & 9 & 4 & 88 & 3 & 4 & 2 & 97 & 1 & 4.17 \\
\hline 1 & S2 & 60 & 12 & 3 & 15 & 0 & 85 & 0 & 1 & 1 & 95 & 2 & 4.21 \\
\hline 2 & N1 & 1 & 62 & 17 & 3 & 0 & 94 & 3 & 0 & 0 & 97 & 1 & 1.96 \\
\hline 2 & N1 & 5 & 32 & 6 & 6 & 3 & 74 & 6 & 1 & 1 & 97 & 1 & 2.35 \\
\hline 2 & N1 & 10 & 71 & 13 & 3 & 0 & 94 & 3 & 4 & 2 & 94 & 1 & 2.51 \\
\hline 2 & N1 & 30 & 36 & 16 & 14 & 8 & 65 & 18 & 7 & 4 & 95 & 1 & 2.97 \\
\hline
\end{tabular}




\begin{tabular}{cccccccccccccc}
\hline Site & $\begin{array}{c}\text { Per. } \\
\text { Transect }\end{array}$ & $\begin{array}{c}\text { Parallel } \\
\text { Transect }\end{array}$ & $\begin{array}{c}\text { \% Herb } \\
\text { Cover } \\
\pm \text { SE }\end{array}$ & $\begin{array}{c}\text { \% Bare } \\
\text { Soil } \\
\pm \text { SE }\end{array}$ & $\begin{array}{c}\text { \% Leaf } \\
\text { Litter }\end{array}$ & $\begin{array}{c}\% \text { CWD } \\
\pm \text { SE }\end{array}$ & $\begin{array}{c}\text { \% Canopy } \\
\text { Closure } \\
\pm \text { SE }\end{array}$ & \\
\hline 2 & N1 & 60 & 3 & 0 & 3 & 0 & 98 & 0 & 1 & 1 & 93 & 1 & 2.78 \\
2 & $\mathrm{~N} 2$ & 1 & 74 & 6 & 18 & 7 & 83 & 7 & 1 & 1 & 94 & 1 & 2.33 \\
2 & $\mathrm{~N} 2$ & 5 & 68 & 6 & 3 & 0 & 98 & 0 & 3 & 2 & 91 & 3 & 2.32 \\
2 & $\mathrm{~N} 2$ & 10 & 94 & 3 & 9 & 4 & 88 & 3 & 0 & 0 & 83 & 3 & 2.69 \\
2 & $\mathrm{~N} 2$ & 30 & 56 & 15 & 15 & 0 & 74 & 6 & 27 & 6 & 83 & 5 & 3.23 \\
2 & $\mathrm{~N} 2$ & 60 & 68 & 22 & 3 & 0 & 94 & 3 & 1 & 1 & 90 & 1 & 2.57 \\
2 & $\mathrm{~S} 1$ & 1 & 59 & 14 & 3 & 0 & 98 & 0 & 0 & 0 & 91 & 4 & 4.17 \\
2 & $\mathrm{~S} 1$ & 5 & 14 & 8 & 6 & 3 & 88 & 3 & 13 & 6 & 91 & 2 & 3.45 \\
2 & $\mathrm{~S} 1$ & 10 & 59 & 19 & 3 & 0 & 88 & 3 & 5 & 2 & 89 & 3 & 2.85 \\
2 & $\mathrm{~S} 1$ & 30 & 73 & 12 & 3 & 0 & 91 & 4 & 8 & 3 & 85 & 3 & 2.31 \\
2 & $\mathrm{~S} 1$ & 60 & 94 & 3 & 3 & 0 & 98 & 0 & 3 & 3 & 90 & 4 & 2.33 \\
2 & $\mathrm{~S} 2$ & 1 & 77 & 9 & 12 & 3 & 88 & 3 & 0 & 0 & 95 & 3 & 2.62 \\
2 & $\mathrm{~S} 2$ & 5 & 14 & 8 & 9 & 4 & 83 & 7 & 2 & 1 & 95 & 0 & 3.57 \\
2 & $\mathrm{~S} 2$ & 10 & 77 & 9 & 3 & 0 & 98 & 0 & 0 & 0 & 91 & 2 & 3.17 \\
2 & $\mathrm{~S} 2$ & 30 & 89 & 9 & 3 & 0 & 98 & 0 & 0 & 0 & 88 & 3 & 2.35 \\
2 & $\mathrm{~S} 2$ & 60 & 88 & 3 & 26 & 24 & 71 & 23 & 0 & 0 & 93 & 1 & 2.67 \\
3 & $\mathrm{~N} 1$ & 1 & 94 & 3 & 3 & 0 & 98 & 0 & 0 & 0 & 83 & 3 & 2.72 \\
3 & $\mathrm{~N} 1$ & 5 & 76 & 13 & 3 & 0 & 98 & 0 & 0 & 0 & 95 & 1 & 4.78 \\
3 & $\mathrm{~N} 1$ & 10 & 38 & 17 & 6 & 3 & 94 & 3 & 4 & 2 & 93 & 2 & 4.84 \\
3 & $\mathrm{~N} 1$ & 30 & 11 & 9 & 18 & 15 & 83 & 15 & 0 & 0 & 89 & 2 & 4.11 \\
3 & $\mathrm{~N} 1$ & 60 & 33 & 11 & 3 & 0 & 94 & 3 & 1 & 0 & 93 & 1 & 4.18 \\
3 & $\mathrm{~N} 2$ & 1 & 94 & 3 & 3 & 0 & 98 & 0 & 0 & 0 & 78 & 8 & 3.53 \\
3 & $\mathrm{~N} 2$ & 5 & 68 & 6 & 3 & 0 & 98 & 0 & 0 & 0 & 96 & 1 & 4 \\
3 & $\mathrm{~N} 2$ & 10 & 68 & 6 & 3 & 0 & 98 & 0 & 0 & 0 & 89 & 1 & 3.75 \\
3 & $\mathrm{~N} 2$ & 30 & 29 & 19 & 3 & 0 & 98 & 0 & 0 & 0 & 94 & 2 & 4.05 \\
\hline
\end{tabular}




\begin{tabular}{|c|c|c|c|c|c|c|c|c|c|c|c|c|c|}
\hline Site & $\begin{array}{c}\text { Per. } \\
\text { Transect }\end{array}$ & $\begin{array}{l}\text { Parallel } \\
\text { Transect }\end{array}$ & & & & & & & & & $\begin{array}{r}\% \mathrm{C} \\
\mathrm{Cl} \\
+\end{array}$ & & LAI \\
\hline 3 & N2 & 60 & 44 & 11 & 3 & $\overline{0}$ & 98 & 0 & $\overline{0}$ & 0 & 87 & 6 & 4.12 \\
\hline 3 & S1 & 1 & 80 & 10 & 3 & 0 & 94 & 3 & 0 & 0 & 90 & 4 & 2.19 \\
\hline 3 & S1 & 5 & 68 & 11 & 44 & 24 & 56 & 24 & 4 & 3 & 95 & 1 & 2.52 \\
\hline 3 & S1 & 10 & 77 & 9 & 64 & 21 & 33 & 22 & 3 & 2 & 91 & 2 & 2.66 \\
\hline 3 & S1 & 30 & 32 & 20 & 3 & 0 & 98 & 0 & 0 & 0 & 91 & 2 & 2.76 \\
\hline 3 & S1 & 60 & 44 & 11 & 6 & 3 & 94 & 3 & 1 & 0 & 93 & 3 & 4.52 \\
\hline 3 & S2 & 1 & 94 & 3 & 91 & 4 & 9 & 4 & 2 & 1 & 81 & 1 & 3.45 \\
\hline 3 & $\mathrm{~S} 2$ & 5 & 77 & 9 & 91 & 4 & 9 & 4 & 2 & 1 & 81 & 5 & 4.36 \\
\hline
\end{tabular}


Appendix Table 2. Legend of species codes used in NMS ordination graphs.

\begin{tabular}{ll}
\hline \hline Species & Code \\
\hline TREES & \\
Acer sp. & $\mathrm{ACER}$ \\
Acer rubrum & $\mathrm{AcRu}$ \\
Asimina triloba & $\mathrm{AsTr}$ \\
Celtis laevigata & $\mathrm{CeLa}$ \\
Diospyros virginiana & $\mathrm{DiVi}$ \\
Fraxinus pennsylvanica & $\mathrm{FrPe}$ \\
Liriodendron styraciflua & $\mathrm{LiSt}$ \\
Nyss sylvatica & $\mathrm{NySy}$ \\
Quercus bicolor & $\mathrm{QuBi}$ \\
Quercus michauxii & $\mathrm{QuMi}$ \\
Quercus palustris & $\mathrm{QuPa}$ \\
Ulmus rubra & $\mathrm{UIRu}$ \\
SHRUBS & \\
Cephalanthus occidentalis & $\mathrm{CeOc}$ \\
Cornus foemina & $\mathrm{CoFo}$ \\
Lindera benzoin & $\mathrm{LiBe}$ \\
Lonicera maackii & $\mathrm{LoMa}$ \\
Rosaceae & $\mathrm{ROSA}$ \\
Rubus sp. & $\mathrm{RUBU}$ \\
Sambucus canadensis & $\mathrm{SaCa}$ \\
VINES & \\
Campsis radicans & $\mathrm{CaRa}$ \\
Euonymus fortunei & $\mathrm{EuFo}$ \\
Lonicera japonica & $\mathrm{LoJa}$ \\
Menispermum canadense & $\mathrm{MeCa}$ \\
Smilax sp. & $\mathrm{SMIL}$ \\
Toxicodendron radicans & $\mathrm{ToRa}$ \\
Vitaceae & $\mathrm{VITA}$ \\
\hline \hline
\end{tabular}


Appendix Table 3. Mean density, basal area and importance values for adult trees $(>2.5$ $\mathrm{cm} \mathrm{dbh}$ ) in forest edges in interiors. Values are averaged over four edge and interior $12 \times 12 \mathrm{~m}$ plots per site ( 8 plots per site).

\begin{tabular}{|c|c|c|c|c|c|c|c|c|c|c|c|c|c|}
\hline \multirow[b]{2}{*}{ Site } & \multirow[b]{2}{*}{ Species } & \multicolumn{6}{|c|}{ Edge } & \multicolumn{6}{|c|}{ Interior } \\
\hline & & \begin{tabular}{|l|} 
Mean \\
Density
\end{tabular} & $\begin{array}{l}\text { Std. } \\
\text { Error }\end{array}$ & $\begin{array}{c}\text { Mean } \\
\text { IV }\end{array}$ & $\begin{array}{l}\text { Std. } \\
\text { Error }\end{array}$ & $\begin{array}{c}\text { Mean } \\
\text { BA }\end{array}$ & $\begin{array}{c}\text { Std. } \\
\text { Error }\end{array}$ & \begin{tabular}{|c|} 
Mean \\
Density
\end{tabular} & $\begin{array}{l}\text { Std. } \\
\text { Error }\end{array}$ & $\begin{array}{l}\text { Mean } \\
\text { IV }\end{array}$ & $\begin{array}{l}\text { Std. } \\
\text { Error }\end{array}$ & $\begin{array}{c}\text { Mean } \\
\text { BA }\end{array}$ & $\begin{array}{c}\text { Std. } \\
\text { Error }\end{array}$ \\
\hline 1 & Acer negundo & 0 & 0 & 0 & 0 & 0.0 & 0.0 & 0 & 0 & 0 & $\overline{0}$ & 0.0 & 0.0 \\
\hline 1 & Acer rubrum & 712 & 265 & 33 & 4 & 14.7 & 2.5 & 469 & 182 & 49 & 7 & 27.0 & 5.8 \\
\hline 1 & $\begin{array}{c}\text { Acer } \\
\text { saccharinum }\end{array}$ & 0 & 0 & 0 & 0 & 0.0 & 0.0 & 0 & 0 & 0 & 0 & 0.0 & 0.0 \\
\hline 1 & Carya & 17 & 17 & 0 & 0 & 0.0 & 0.0 & 0 & 0 & 0 & 0 & 0.0 & 0.0 \\
\hline 1 & $\begin{array}{c}\text { Celtis } \\
\text { laevigata }\end{array}$ & 35 & 20 & 1 & 0 & 0.0 & 0.0 & 35 & 35 & 6 & 6 & 2.6 & 2.6 \\
\hline 1 & $\begin{array}{l}\text { Cornus } \\
\text { florida }\end{array}$ & 17 & 17 & 0 & 0 & 0.0 & 0.0 & 0 & 0 & 0 & 0 & 0.0 & 0.0 \\
\hline 1 & $\begin{array}{l}\text { Diospyros } \\
\text { virginiana }\end{array}$ & 0 & 0 & 0 & 0 & 0.0 & 0.0 & 0 & 0 & 0 & 0 & 0.0 & 0.0 \\
\hline 1 & $\begin{array}{c}\text { Fagus } \\
\text { grandifolia }\end{array}$ & 17 & 17 & 0 & 0 & 0.0 & 0.0 & 0 & 0 & 0 & 0 & 0.0 & 0.0 \\
\hline 1 & $\begin{array}{c}\text { Fraxinus } \\
\text { pennsylvanica }\end{array}$ & 365 & 173 & 22 & 7 & 9.7 & 3.3 & 260 & 171 & 24 & 11 & 11.1 & 5.4 \\
\hline 1 & $\begin{array}{l}\text { Juniperus } \\
\text { virginiana }\end{array}$ & 35 & 35 & 1 & 1 & 0.5 & 0.5 & 0 & 0 & 0 & 0 & 0.0 & 0.0 \\
\hline 1 & $\begin{array}{l}\text { Liquidambar } \\
\text { styraciflua }\end{array}$ & 174 & 104 & 13 & 9 & 11.3 & 10.2 & 87 & 66 & 4 & 2 & 0.3 & 0.2 \\
\hline 1 & $\begin{array}{c}\text { Liriodendron } \\
\text { tulipifera }\end{array}$ & 104 & 60 & 5 & 3 & 3.2 & 2.0 & 0 & 0 & 0 & 0 & 0.0 & 0.0 \\
\hline 1 & $\begin{array}{c}\text { Nyssa } \\
\text { sylvatica }\end{array}$ & 35 & 35 & 2 & 2 & 1.2 & 1.2 & 0 & 0 & 0 & 0 & 0.0 & 0.0 \\
\hline 1 & $\begin{array}{l}\text { Platanus } \\
\text { occidentalis }\end{array}$ & 104 & 45 & 5 & 2 & 2.8 & 1.1 & 104 & 66 & 14 & 10 & 5.5 & 3.8 \\
\hline 1 & $\begin{array}{l}\text { Populus } \\
\text { deltoides }\end{array}$ & 35 & 20 & 2 & 2 & 1.1 & 1.0 & 0 & 0 & 0 & 0 & 0.0 & 0.0 \\
\hline 1 & $\begin{array}{l}\text { Quercus } \\
\text { bicolor }\end{array}$ & 0 & 0 & 0 & 0 & 0.0 & 0.0 & 0 & 0 & 0 & 0 & 0.0 & 0.0 \\
\hline 1 & $\begin{array}{l}\text { Quercus } \\
\text { lyrata }\end{array}$ & 0 & 0 & 0 & 0 & 0.0 & 0.0 & 0 & 0 & 0 & 0 & 0.0 & 0.0 \\
\hline 1 & $\begin{array}{l}\text { Quercus } \\
\text { palustris }\end{array}$ & 17 & 17 & 1 & 1 & 0.3 & 0.3 & 17 & 17 & 2 & 2 & 0.0 & 0.0 \\
\hline 1 & Salix nigra & 0 & 0 & 0 & 0 & 0.0 & 0.0 & 0 & 0 & 0 & 0 & 0.0 & 0.0 \\
\hline 1 & $\begin{array}{c}\text { Ulmus } \\
\text { americana }\end{array}$ & 17 & 17 & 1 & 1 & 0.8 & 0.8 & 17 & 17 & 2 & 2 & 0.9 & 0.9 \\
\hline \multirow[t]{2}{*}{1} & Ulmus rubra & 226 & 72 & 12 & 6 & 1.1 & 0.4 & 17 & 17 & 1 & 1 & 0.0 & 0.0 \\
\hline & TOTAL & 1910 & & 100 & & 46.8 & & 1007 & & 100 & & 47.4 & \\
\hline 2 & Acer negundo & 17 & 17 & 1 & $x$ & 0.2 & 0.2 & 17 & 17 & 1 & & 0.1 & 0.1 \\
\hline 2 & Acer rubrum & 399 & 87 & 29 & 5 & 16.9 & 4.6 & 313 & 128 & 34 & 7 & 19.9 & 8.4 \\
\hline 2 & $\begin{array}{c}\text { Acer } \\
\text { saccharinum }\end{array}$ & 0 & 0 & 0 & 0 & 0.0 & 0.0 & 0 & 0 & 0 & 0 & 0.0 & 0.0 \\
\hline 2 & Carya & 0 & 0 & 0 & 0 & 0.0 & 0.0 & 0 & 0 & 0 & 0 & 0.0 & 0.0 \\
\hline
\end{tabular}




\begin{tabular}{|c|c|c|c|c|c|c|c|c|c|c|c|c|c|}
\hline \multirow[b]{2}{*}{ Site } & \multirow[b]{2}{*}{ Species } & \multicolumn{6}{|c|}{ Edge } & \multicolumn{6}{|c|}{ Interior } \\
\hline & & $\begin{array}{l}\text { Mean } \\
\text { Density }\end{array}$ & $\begin{array}{l}\text { Std. } \\
\text { Error }\end{array}$ & $\begin{array}{l}\text { Mean } \\
\text { IV }\end{array}$ & $\begin{array}{l}\text { Std. } \\
\text { Error }\end{array}$ & $\begin{array}{c}\text { Mean } \\
\text { BA }\end{array}$ & $\begin{array}{l}\text { Std. } \\
\text { Error }\end{array}$ & $\begin{array}{l}\text { Mean } \\
\text { Density }\end{array}$ & $\begin{array}{l}\text { Std. } \\
\text { Error }\end{array}$ & $\begin{array}{l}\text { Mean } \\
\text { IV }\end{array}$ & $\begin{array}{l}\text { Std. } \\
\text { Error }\end{array}$ & $\begin{array}{c}\text { Mean } \\
\text { BA }\end{array}$ & $\begin{array}{l}\text { Std. } \\
\text { Error }\end{array}$ \\
\hline 2 & $\begin{array}{c}\text { Celtis } \\
\text { laevigata }\end{array}$ & 677 & 187 & 25 & 5 & 6.1 & 2.0 & 382 & 174 & 23 & 9 & 2.7 & 0.9 \\
\hline 2 & $\begin{array}{l}\text { Cornus } \\
\text { florida }\end{array}$ & 0 & 0 & 0 & 0 & 0.0 & 0.0 & 0 & 0 & 0 & 0 & 0.0 & 0.0 \\
\hline 2 & $\begin{array}{l}\text { Diospyros } \\
\text { virginiana }\end{array}$ & 0 & 0 & 0 & 0 & 0.0 & 0.0 & 0 & 0 & 0 & 0 & 0.0 & 0.0 \\
\hline 2 & $\begin{array}{c}\text { Fagus } \\
\text { grandifolia }\end{array}$ & 0 & 0 & 0 & 0 & 0.0 & 0.0 & 0 & 0 & 0 & 0 & 0.0 & 0.0 \\
\hline 2 & $\begin{array}{c}\text { Fraxinus } \\
\text { pennsylvanica }\end{array}$ & 174 & 104 & 6 & 4 & 1.7 & 1.4 & 243 & 115 & 23 & 6 & 12.7 & 3.9 \\
\hline 2 & $\begin{array}{l}\text { Juniperus } \\
\text { virginiana }\end{array}$ & 0 & 0 & 0 & 0 & 0.0 & 0.0 & 0 & 0 & 0 & 0 & 0.0 & 0.0 \\
\hline 2 & $\begin{array}{c}\text { Liquidambar } \\
\text { styraciflua }\end{array}$ & 0 & 0 & 0 & 0 & 0.0 & 0.0 & 0 & 0 & 0 & 0 & 0.0 & 0.0 \\
\hline 2 & $\begin{array}{c}\text { Liriodendron } \\
\text { tulipifera }\end{array}$ & 0 & 0 & 0 & 0 & 0.0 & 0.0 & 0 & 0 & 0 & 0 & 0.0 & 0.0 \\
\hline 2 & $\begin{array}{c}\text { Nyssa } \\
\text { sylvatica }\end{array}$ & 0 & 0 & 0 & 0 & 0.0 & 0.0 & 0 & 0 & 0 & 0 & 0.0 & 0.0 \\
\hline 2 & $\begin{array}{l}\text { Platanus } \\
\text { occidentalis }\end{array}$ & 17 & 17 & 5 & 5 & 2.9 & 2.9 & 0 & 0 & 0 & 0 & 0.0 & 0.0 \\
\hline 2 & $\begin{array}{l}\text { Populus } \\
\text { deltoides }\end{array}$ & 52 & 33 & 5 & 5 & 2.2 & 2.2 & 69 & 69 & 10 & 10 & 9.2 & 9.2 \\
\hline 2 & $\begin{array}{l}\text { Quercus } \\
\text { bicolor }\end{array}$ & 17 & 17 & 0 & 0 & 0.0 & 0.0 & 0 & 0 & 0 & 0 & 0.0 & 0.0 \\
\hline 2 & $\begin{array}{l}\text { Quercus } \\
\text { lyrata }\end{array}$ & 0 & 0 & 0 & 0 & 0.0 & 0.0 & 17 & 17 & 4 & 4 & 1.8 & 1.8 \\
\hline 2 & $\begin{array}{l}\text { Quercus } \\
\text { palustris }\end{array}$ & 87 & 33 & 10 & 7 & 10.4 & 9.9 & 0 & 0 & 0 & 0 & 0.0 & 0.0 \\
\hline 2 & Salix nigra & 0 & 0 & 0 & 0 & 0.0 & 0.0 & 0 & 0 & 0 & 0 & 0.0 & 0.0 \\
\hline 2 & $\begin{array}{c}\text { Ulmus } \\
\text { americana }\end{array}$ & 0 & 0 & 0 & 0 & 0.0 & 0.0 & 0 & 0 & 0 & 0 & 0.0 & 0.0 \\
\hline \multirow[t]{2}{*}{2} & Ulmus rubra & 382 & 146 & 18 & 7 & 5.2 & 2.2 & 69 & 49 & 5 & 4 & 0.4 & 0.2 \\
\hline & TOTAL & 1823 & & 100 & & 45.5 & & 1111 & & 100 & & 46.8 & \\
\hline 3 & Acer negundo & 0 & 0 & 0 & 0 & 0.0 & 0.0 & 0 & 0 & 0 & 0 & 0.0 & 0.0 \\
\hline 3 & Acer rubrum & 729 & 454 & 29 & 8 & 11.3 & 3.8 & 938 & 500 & 41 & 11 & 11.5 & 4.2 \\
\hline 3 & $\begin{array}{c}\text { Acer } \\
\text { saccharinum }\end{array}$ & 52 & 33 & 2 & 1 & 0.3 & 0.3 & 0 & 0 & 0 & 0 & 0.0 & 0.0 \\
\hline 3 & Carya & 0 & 0 & 0 & 0 & 0.0 & 0.0 & 0 & 0 & 0 & 0 & 0.0 & 0.0 \\
\hline 3 & $\begin{array}{c}\text { Celtis } \\
\text { laevigata }\end{array}$ & 365 & 365 & 11 & 11 & 3.5 & 3.5 & 208 & 208 & 14 & 14 & 2.1 & 2.1 \\
\hline 3 & $\begin{array}{l}\text { Cornus } \\
\text { florida }\end{array}$ & 0 & 0 & 0 & 0 & 0.0 & 0.0 & 0 & 0 & 0 & 0 & 0.0 & 0.0 \\
\hline 3 & $\begin{array}{l}\text { Diospyros } \\
\text { virginiana }\end{array}$ & 52 & 33 & 1 & 1 & 0.1 & 0.1 & 0 & 0 & 0 & 0 & 0.0 & 0.0 \\
\hline 3 & $\begin{array}{c}\text { Fagus } \\
\text { grandifolia }\end{array}$ & 0 & 0 & 0 & 0 & 0.0 & 0.0 & 0 & 0 & 0 & 0 & 0.0 & 0.0 \\
\hline
\end{tabular}




\begin{tabular}{|c|c|c|c|c|c|c|c|c|c|c|c|c|c|}
\hline \multirow[b]{2}{*}{ Site } & \multirow[b]{2}{*}{ Species } & \multicolumn{6}{|c|}{ Edge } & \multicolumn{6}{|c|}{ Interior } \\
\hline & & $\begin{array}{l}\text { Mean } \\
\text { Density }\end{array}$ & $\begin{array}{l}\text { Std. } \\
\text { Error }\end{array}$ & $\begin{array}{c}\text { Mean } \\
\text { IV }\end{array}$ & $\begin{array}{l}\text { Std. } \\
\text { Error }\end{array}$ & $\begin{array}{c}\text { Mean } \\
\text { BA }\end{array}$ & $\begin{array}{l}\text { Std. } \\
\text { Error }\end{array}$ & $\begin{array}{l}\text { Mean } \\
\text { Density }\end{array}$ & $\begin{array}{l}\text { Std. } \\
\text { Error }\end{array}$ & $\begin{array}{c}\text { Mean } \\
\text { IV }\end{array}$ & $\begin{array}{l}\text { Std. } \\
\text { Error }\end{array}$ & $\begin{array}{c}\text { Mean } \\
\text { BA }\end{array}$ & $\begin{array}{l}\text { Std. } \\
\text { Error }\end{array}$ \\
\hline 3 & $\begin{array}{c}\text { Fraxinus } \\
\text { pennsylvanica }\end{array}$ & 694 & 235 & 24 & 6 & 7.0 & 2.7 & 313 & 205 & 17 & 6 & 7.1 & 2.6 \\
\hline 3 & $\begin{array}{l}\text { Juniperus } \\
\text { virginiana }\end{array}$ & 0 & 0 & 0 & 0 & 0.0 & 0.0 & 0 & 0 & 0 & 0 & 0.0 & 0.0 \\
\hline 3 & $\begin{array}{c}\text { Liquidambar } \\
\text { styraciflua }\end{array}$ & 69 & 40 & 3 & 3 & 0.7 & 0.7 & 17 & 17 & 7 & 7 & 5.4 & 5.4 \\
\hline 3 & $\begin{array}{c}\text { Liriodendron } \\
\text { tulipifera }\end{array}$ & 0 & 0 & 0 & 0 & 0.0 & 0.0 & 0 & 0 & 0 & 0 & 0.0 & 0.0 \\
\hline 3 & $\begin{array}{c}\text { Nyssa } \\
\text { sylvatica }\end{array}$ & 139 & 139 & 7 & 7 & 0.9 & 0.9 & 0 & 0 & 0 & 0 & 0.0 & 0.0 \\
\hline 3 & $\begin{array}{c}\text { Platanus } \\
\text { occidentalis }\end{array}$ & 0 & 0 & 0 & 0 & 0.0 & 0.0 & 0 & 0 & 0 & 0 & 0.0 & 0.0 \\
\hline 3 & $\begin{array}{l}\text { Populus } \\
\text { deltoides }\end{array}$ & 35 & 35 & 1 & 1 & 0.1 & 0.1 & 17 & 17 & 1 & 1 & 0.5 & 0.5 \\
\hline 3 & $\begin{array}{l}\text { Quercus } \\
\text { bicolor }\end{array}$ & 35 & 35 & 1 & 1 & 0.0 & 0.0 & 17 & 17 & 4 & 4 & 1.8 & 1.8 \\
\hline 3 & $\begin{array}{c}\text { Quercus } \\
\text { lyrata }\end{array}$ & 0 & 0 & 0 & 0 & 0.0 & 0.0 & 0 & 0 & 0 & 0 & 0.0 & 0.0 \\
\hline 3 & $\begin{array}{l}\text { Quercus } \\
\text { palustris }\end{array}$ & 330 & 284 & 9 & 8 & 1.3 & 0.9 & 69 & 49 & 11 & 6 & 6.0 & 3.7 \\
\hline 3 & Salix nigra & 52 & 52 & 4 & 4 & 1.1 & 1.1 & 0 & 0 & 0 & 0 & 0.0 & 0.0 \\
\hline 3 & $\begin{array}{c}\text { Ulmus } \\
\text { americana }\end{array}$ & 0 & 0 & 0 & 0 & 0.0 & 0.0 & 0 & 0 & 0 & 0 & 0.0 & 0.0 \\
\hline \multirow[t]{2}{*}{3} & Ulmus rubra & 139 & 49 & 8 & 3 & 3.7 & 2.0 & 104 & 45 & 5 & 2 & 0.7 & 0.3 \\
\hline & TOTAL & 2691 & & 100 & & 30.1 & & 1684 & & 100 & & 35.0 & \\
\hline
\end{tabular}


Appendix Table 4. Results of mixed model regression testing for effects of site, side (north vs. south edge orientation) and position (edge vs. interior position) on adult tree species richness (PROC MIXED, SAS 9.4). Shannon diversity was based on basal area of adults and was modeled with fixed effects only because of overfitting when random effects were included (see Statistical Analysis). Bolded p-values are significant at the 0.05 level.

\begin{tabular}{ccrrr}
\hline \hline Fesponse & Fixed Effects & DF & $\begin{array}{c}\text { Chi- } \\
\text { Square }\end{array}$ & $\mathrm{p}$ \\
\hline Species Richness & Site & 2 & 0.39 & 0.8232 \\
& Side & 1 & 0.23 & 0.6313 \\
& Position (Edge vs. Interior) & $\mathbf{1}$ & $\mathbf{7 . 8 3}$ & $\mathbf{0 . 0 0 5 1}$ \\
& Site*Side & 2 & 0.19 & 0.9099 \\
& Side*Position & 1 & 0.03 & 0.8555 \\
Site*Position & 2 & 0.79 & 0.6746 \\
& Site*Side*Position & 2 & 0.7 & 0.7036 \\
\hline \hline
\end{tabular}


Appendix Table 5. Shannon-Weiner diversity index values $(\mathrm{H})$ and species richness of all woody vegetation layers, across all sites and with distance from edge. Values of $\mathrm{H}$ are based on basal area and percent cover for adult trees and vines, respectively, and stem density for all other vegetation layers. For adult trees, $12 \times 12 \mathrm{~m}$ edge plots began at the forest edge and extended $12 \mathrm{~m}$ in, and interior plots were centered at $60 \mathrm{~m}$ from the edge. All other data was collected by subsampling in parallel $12 \times 2 \mathrm{~m}$ transects centered at 1, 5, 10, 30 and $60 \mathrm{~m}$ from the forest edge, in four locations per site. Values in bold represent the highest values of $\mathrm{H}$ and species richness within each vegetation layer and site, and across sites.

\begin{tabular}{|c|c|c|c|c|c|c|c|c|c|c|}
\hline & & & \multicolumn{2}{|c|}{ Site 3: Wet Site } & \multicolumn{2}{|c|}{ Site 2: Intermediate Site } & \multicolumn{2}{|c|}{ Site 1: Dry Site } & \multicolumn{2}{|c|}{ Across Sites } \\
\hline Layer & $\begin{array}{l}\text { Distance } \\
\text { from Edge }\end{array}$ & $\mathrm{n}$ & Mean & & Mean & & Mean & & Mean & \\
\hline Adults & EDGE & 4 & 1.37 & 0.17 & 1.22 & 0.12 & 1.38 & 0.20 & 1.32 & 0.05 \\
\hline Adults & INT & 4 & 1.17 & 0.15 & 0.95 & 0.13 & 0.87 & 0.07 & 1.00 & 0.09 \\
\hline Sapling & $1 \mathrm{~m}$ & 4 & 0.79 & 0.15 & 0.98 & 0.22 & 1.35 & 0.21 & 1.04 & 0.16 \\
\hline Sapling & $5 \mathrm{~m}$ & 4 & 1.13 & 0.23 & 0.63 & 0.26 & 1.15 & 0.19 & 0.97 & 0.17 \\
\hline Sapling & $10 \mathrm{~m}$ & 4 & 1.01 & 0.16 & 0.98 & 0.21 & 0.92 & 0.31 & 0.97 & 0.03 \\
\hline Sapling & $30 \mathrm{~m}$ & 4 & 0.53 & 0.31 & 0.73 & 0.10 & 0.94 & 0.10 & 0.73 & 0.12 \\
\hline Sapling & $60 \mathrm{~m}$ & 4 & 0.65 & 0.28 & 0.34 & 0.23 & 1.07 & 0.18 & 0.68 & 0.21 \\
\hline Seedling & $1 \mathrm{~m}$ & 4 & 0.65 & 0.26 & 0.50 & 0.23 & 0.61 & 0.35 & 0.59 & 0.04 \\
\hline Seedling & $5 \mathrm{~m}$ & 4 & 0.45 & 0.26 & 0.39 & 0.23 & 0.35 & 0.20 & 0.39 & 0.03 \\
\hline Seedling & $10 \mathrm{~m}$ & 4 & 0.31 & 0.13 & 0.59 & 0.29 & 0.77 & 0.32 & 0.56 & 0.13 \\
\hline Seedling & $30 \mathrm{~m}$ & 4 & 0.40 & 0.27 & 0.34 & 0.26 & 0.80 & 0.17 & 0.51 & 0.14 \\
\hline Seedling & $60 \mathrm{~m}$ & 4 & 0.36 & 0.20 & 0.37 & 0.17 & 0.49 & 0.31 & 0.41 & 0.04 \\
\hline Shrubs & $1 \mathrm{~m}$ & 4 & 0.54 & 0.24 & 0.00 & 0.00 & 0.77 & 0.28 & 0.44 & 0.23 \\
\hline Shrubs & $5 \mathrm{~m}$ & 4 & 0.26 & 0.15 & 0.37 & 0.21 & 0.73 & 0.25 & 0.45 & 0.14 \\
\hline Shrubs & $10 \mathrm{~m}$ & 4 & 0.17 & 0.17 & 0.16 & 0.16 & 0.72 & 0.15 & 0.35 & 0.18 \\
\hline Shrubs & $30 \mathrm{~m}$ & 4 & 0.53 & 0.19 & 0.40 & 0.15 & 0.82 & 0.12 & 0.58 & 0.12 \\
\hline Shrubs & $60 \mathrm{~m}$ & 4 & 0.06 & 0.06 & 0.10 & 0.10 & 0.89 & 0.03 & 0.35 & 0.27 \\
\hline Vines & $1 \mathrm{~m}$ & 4 & 0.48 & 0.22 & 0.68 & 0.16 & 1.14 & 0.13 & 0.77 & 0.20 \\
\hline Vines & $5 \mathrm{~m}$ & 4 & 0.57 & 0.20 & 0.60 & 0.10 & 0.96 & 0.29 & 0.71 & 0.12 \\
\hline Vines & $10 \mathrm{~m}$ & 4 & 0.61 & 0.25 & 0.44 & 0.24 & 0.64 & 0.22 & 0.56 & 0.06 \\
\hline Vines & $30 \mathrm{~m}$ & 4 & 0.30 & 0.18 & 0.44 & 0.27 & 1.12 & 0.27 & 0.62 & 0.25 \\
\hline Vines & $60 \mathrm{~m}$ & 4 & 0.13 & 0.09 & 0.45 & 0.12 & 1.11 & 0.17 & 0.56 & 0.29 \\
\hline
\end{tabular}


Appendix Table 6. Results of mixed model regression testing for significance of fixed and random effects on sapling (dbh $<2.5 \mathrm{~cm}$, $>0.5 \mathrm{dbh}$ ) species richness. Modeled fixed effects were site, side (north vs. south edge), position (edge or interior location), 2 and 3 way interactions between these variables. Edge-to-interior transect (in table as EITransect) was included as a random blocking effect, nested within each site and side.

\begin{tabular}{|c|c|c|c|c|c|c|c|c|c|c|}
\hline & \multicolumn{5}{|c|}{ Fixed Effects } & \multicolumn{5}{|c|}{ Random Effects } \\
\hline & Effect & $\begin{array}{c}\text { Num } \\
\text { DF }\end{array}$ & $\begin{array}{l}\text { Den } \\
\text { DF }\end{array}$ & $\begin{array}{c}\mathrm{F} \\
\text { Value }\end{array}$ & $\mathrm{p}$ & Covariance Parameter & Estimate & $\begin{array}{l}\text { Standard } \\
\text { Error }\end{array}$ & $\begin{array}{c}\mathrm{Z} \\
\text { Value }\end{array}$ & $\mathrm{p}$ \\
\hline \multirow[t]{7}{*}{ Species Richness } & Site & 2 & 6 & 0.16 & 0.8542 & \multirow[t]{7}{*}{ EITransect(Site*side) } & \multirow[t]{7}{*}{0.009923} & \multirow[t]{7}{*}{0.04221} & \multirow[t]{7}{*}{0.24} & \multirow[t]{7}{*}{0.4071} \\
\hline & Side & 1 & 6 & 2.62 & 0.1569 & & & & & \\
\hline & Distance from Edge & 1 & 42 & 6.81 & 0.0125 & & & & & \\
\hline & Site*Side & 2 & 6 & 1.57 & 0.2824 & & & & & \\
\hline & $\begin{array}{l}\text { Side*Distance from } \\
\text { Edge }\end{array}$ & 1 & 42 & 0.08 & 0.7789 & & & & & \\
\hline & Site*Distance from Edge & 2 & 42 & 0.41 & 0.6636 & & & & & \\
\hline & $\begin{array}{c}\text { Site*Side*Distance from } \\
\text { Edge }\end{array}$ & 2 & 42 & 0.8 & 0.458 & & & & & \\
\hline
\end{tabular}


Appendix Table 7. Mean frequencies, densities and IV values for saplings at varying distance from the forest edge, at each site, and across sites. The highest density and IV values at each distance and site (and across sites) are in bold.

\begin{tabular}{|c|c|c|c|c|c|c|c|c|c|c|c|c|c|c|c|c|c|c|c|c|c|c|c|}
\hline \multirow{3}{*}{$\begin{array}{c}\text { Dist. } \\
1 \\
1\end{array}$} & \multirow{3}{*}{$\begin{array}{c}\text { Species } \\
\text { Acer rubrum }\end{array}$} & \multicolumn{6}{|c|}{ Site 3: Wet Site } & \multicolumn{6}{|c|}{ Site 2: Intermediate } & \multicolumn{6}{|c|}{ Site 1: Dry Site } & \multicolumn{4}{|c|}{$\begin{array}{l}\begin{array}{l}\text { Overall Means } \\
\text { (Across Sites) }\end{array} \\
\end{array}$} \\
\hline & & \multicolumn{2}{|c|}{$\begin{array}{l}\text { Mean } \\
\text { Freq. } \pm \\
\text { SE }\end{array}$} & \multicolumn{2}{|c|}{$\begin{array}{c}\text { Mean } \\
\text { Density } \pm \\
\text { SE }\end{array}$} & \multicolumn{2}{|c|}{$\begin{array}{c}\text { Mean IV } \\
\pm \mathrm{SE}\end{array}$} & \multicolumn{2}{|c|}{$\begin{array}{c}\text { Mean } \\
\text { Freq. } \pm \\
\text { SE }\end{array}$} & \multicolumn{2}{|c|}{$\begin{array}{c}\text { Mean } \\
\text { Density } \pm \text { SE }\end{array}$} & \multicolumn{2}{|c|}{$\begin{array}{c}\text { Mean IV } \\
\pm \text { SE }\end{array}$} & \multicolumn{2}{|c|}{$\begin{array}{c}\text { Mean } \\
\text { Freq. } \pm \text { SE }\end{array}$} & \multicolumn{2}{|c|}{$\begin{array}{c}\text { Mean } \\
\text { Density } \pm \text { SE }\end{array}$} & \multicolumn{2}{|c|}{$\begin{array}{c}\text { Mean IV } \\
\pm \mathrm{SE}\end{array}$} & \multicolumn{2}{|c|}{$\begin{array}{c}\text { Mean } \\
\text { IV } \pm \\
\text { SE } \\
\end{array}$} & \multicolumn{2}{|c|}{$\begin{array}{c}\text { Mean } \\
\text { Density } \pm \\
\text { SE }\end{array}$} \\
\hline & & 0.19 & 0.12 & 625 & 442 & 5 & 3 & 0.19 & 0.12 & 1563 & 1362 & 7 & 4 & 0.25 & 0.18 & 1094 & 898 & 7 & 5 & 7 & 0 & 1094 & 271 \\
\hline 1 & $\begin{array}{c}\text { Acer } \\
\text { saccharinum }\end{array}$ & 0.06 & 0.06 & 156 & 156 & 1 & 1 & 0.06 & 0.06 & 156 & 156 & 1 & 1 & 0.06 & 0.06 & 156 & 156 & 1 & 1 & 1 & 0 & 156 & 0 \\
\hline 1 & $\begin{array}{c}\text { Celtis } \\
\text { laevigata }\end{array}$ & 0.00 & 0.00 & 0 & 0 & 0 & 0 & 0.44 & 0.19 & 3438 & 1813 & 15 & 5 & 0.38 & 0.22 & 1094 & 693 & 18 & 14 & 11 & 2 & 1510 & 1014 \\
\hline 1 & $\begin{array}{l}\text { Diospyros } \\
\text { virginiana }\end{array}$ & 0.00 & 0.00 & 0 & 0 & 0 & 0 & 0.00 & 0.00 & 0 & 0 & 0 & 0 & 0.06 & 0.06 & 156 & 156 & 1 & 1 & 0 & 0 & 52 & 52 \\
\hline 1 & $\begin{array}{c}\text { Fraxinus } \\
\text { pennsylvanica }\end{array}$ & 0.63 & 0.22 & 13750 & 7548 & 43 & 17 & 0.81 & 0.19 & 18750 & 6832 & 46 & 12 & 0.50 & 0.23 & 2656 & 1452 & 23 & 8 & 37 & 7 & 11719 & 4756 \\
\hline 1 & $\begin{array}{c}\text { Liquidambar } \\
\text { styraciflua }\end{array}$ & 0.25 & 0.25 & 3438 & 3438 & 8 & 8 & 0.00 & 0.00 & 0 & 0 & 0 & 0 & 0.44 & 0.21 & 1563 & 972 & 15 & 7 & 8 & 4 & 1667 & 994 \\
\hline 1 & $\begin{array}{l}\text { Liriodedron } \\
\text { tulipifera }\end{array}$ & 0.06 & 0.06 & 156 & 156 & 1 & 1 & 0.00 & 0.00 & 0 & 0 & 0 & 0 & 0.00 & 0.00 & 0 & 0 & 0 & 0 & 0 & 0 & 52 & 52 \\
\hline 1 & $\begin{array}{c}\text { Nyssa } \\
\text { sylvatica }\end{array}$ & 0.19 & 0.19 & 469 & 469 & 3 & 3 & 0.00 & 0.00 & 0 & 0 & 0 & 0 & 0.00 & 0.00 & 0 & 0 & 0 & 0 & 1 & 0 & 156 & 156 \\
\hline 1 & $\begin{array}{c}\text { Platanus } \\
\text { occidentalis }\end{array}$ & 0.00 & 0.00 & 0 & 0 & 0 & 0 & 0.00 & 0.00 & 0 & 0 & 0 & 0 & 0.06 & 0.06 & 156 & 156 & 8 & 8 & 3 & 2 & 52 & 52 \\
\hline 1 & $\begin{array}{l}\text { Quercus } \\
\text { bicolor }\end{array}$ & 0.06 & 0.06 & 156 & 156 & 1 & 1 & 0.06 & 0.06 & 156 & 156 & 2 & 2 & 0.00 & 0.00 & 0 & 0 & 0 & 0 & 1 & 1 & 104 & 52 \\
\hline 1 & $\begin{array}{l}\text { Quercus } \\
\text { michauxii }\end{array}$ & 0.06 & 0.06 & 156 & 156 & 1 & 1 & 0.00 & 0.00 & 0 & 0 & 0 & 0 & 0.06 & 0.06 & 156 & 156 & 3 & 3 & 2 & 1 & 104 & 52 \\
\hline 1 & $\begin{array}{l}\text { Quercus } \\
\text { palustris }\end{array}$ & 0.63 & 0.16 & 2344 & 822 & 24 & 10 & 0.31 & 0.19 & 2188 & 1362 & 10 & 6 & 0.13 & 0.07 & 313 & 180 & 10 & 8 & 15 & 2 & 1615 & 653 \\
\hline 1 & Salix nigra & 0.00 & 0.00 & 0 & 0 & 0 & 0 & 0.06 & 0.06 & 625 & 625 & 8 & 8 & 0.00 & 0.00 & 0 & 0 & 0 & 0 & 3 & 2 & 208 & 208 \\
\hline 1 & $\begin{array}{l}\text { Sassafras } \\
\text { albidum }\end{array}$ & 0.00 & 0.00 & 0 & 0 & 0 & 0 & 0.00 & 0.00 & 0 & 0 & 0 & 0 & 0.06 & 0.06 & 156 & 156 & 1 & 1 & 0 & 0 & 52 & 52 \\
\hline 1 & Ulmus rubra & 0.25 & 0.18 & 781 & 592 & 10 & 9 & 0.31 & 0.12 & 938 & 403 & 11 & 6 & 0.31 & 0.19 & 1250 & 722 & 9 & 5 & 10 & 1 & 990 & 138 \\
\hline 1 & Unidentified & 0.00 & 0.00 & 0 & 0 & 0 & 0 & 0.00 & 0.00 & 0 & 0 & 0 & 0 & 0.13 & 0.07 & 313 & 180 & 3 & 2 & 1 & 1 & 104 & 104 \\
\hline
\end{tabular}




\begin{tabular}{|c|c|c|c|c|c|c|c|c|c|c|c|c|c|c|c|c|c|c|c|c|c|c|c|}
\hline \multirow{3}{*}{$\begin{array}{c}\text { Dist. } \\
5\end{array}$} & \multirow{3}{*}{$\begin{array}{c}\text { Species } \\
\text { Acer rubrum }\end{array}$} & \multicolumn{6}{|c|}{ Site 3: Wet Site } & \multicolumn{6}{|c|}{ Site 2: Intermediate } & \multicolumn{6}{|c|}{ Site 1: Dry Site } & \multicolumn{4}{|c|}{$\begin{array}{l}\text { Overall Means } \\
\text { (Across Sites) }\end{array}$} \\
\hline & & \multicolumn{2}{|c|}{$\begin{array}{l}\text { Mean } \\
\text { Freq. } \pm \\
\text { SE }\end{array}$} & \multicolumn{2}{|c|}{$\begin{array}{c}\text { Mean } \\
\text { Density } \pm \\
\text { SE }\end{array}$} & \multicolumn{2}{|c|}{$\begin{array}{c}\text { Mean IV } \\
\pm \mathrm{SE}\end{array}$} & \multicolumn{2}{|c|}{$\begin{array}{l}\text { Mean } \\
\text { Freq. } \pm \\
\text { SE }\end{array}$} & \multicolumn{2}{|c|}{$\begin{array}{c}\text { Mean } \\
\text { Density } \pm \mathrm{SE}\end{array}$} & \multicolumn{2}{|c|}{$\begin{array}{c}\text { Mean IV } \\
\pm \mathrm{SE}\end{array}$} & \multicolumn{2}{|c|}{$\begin{array}{c}\text { Mean } \\
\text { Freq. } \pm \text { SE }\end{array}$} & \multicolumn{2}{|c|}{$\begin{array}{c}\text { Mean } \\
\text { Density } \pm \text { SE }\end{array}$} & \multicolumn{2}{|c|}{$\begin{array}{c}\text { Mean IV } \\
\pm \text { SE }\end{array}$} & \multicolumn{2}{|c|}{$\begin{array}{c}\text { Mean } \\
\text { IV } \pm \\
\text { SE }\end{array}$} & \multicolumn{2}{|c|}{$\begin{array}{c}\text { Mean } \\
\text { Density } \pm \\
\text { SE }\end{array}$} \\
\hline & & 0.38 & 0.13 & 2656 & 1123 & 28 & 11 & 0.06 & 0.06 & 156 & 156 & 6 & 6 & 0.06 & 0.06 & 156 & 156 & 8 & 8 & 14 & 2 & 990 & 833 \\
\hline 5 & $\begin{array}{c}\text { Celtis } \\
\text { laevigata }\end{array}$ & 0.25 & 0.25 & 781 & 781 & 7 & 7 & 0.38 & 0.24 & 1094 & 738 & 27 & 16 & 0.19 & 0.12 & 625 & 442 & 20 & 15 & 18 & 3 & 833 & 138 \\
\hline 5 & Crategus spp. & 0.06 & 0.06 & 156 & 156 & 2 & 2 & .06 & 0.06 & 156 & 156 & 3 & 3 & 0.00 & 0.00 & 0 & 0 & 0 & 0 & 2 & 1 & 104 & 52 \\
\hline 5 & $\begin{array}{c}\text { Fraxinus } \\
\text { pennsylvanica }\end{array}$ & 0.50 & 0.23 & 5938 & 3998 & 31 & 12 & 0.13 & 0.07 & 313 & 180 & 10 & 6 & 0.19 & 0.12 & 781 & 469 & 16 & 10 & 19 & 3 & 2344 & 1802 \\
\hline 5 & $\begin{array}{l}\text { Liquidambar } \\
\text { styraciflua }\end{array}$ & 0.19 & 0.19 & 2500 & 2500 & 5 & 5 & 0.00 & 0.00 & 0 & 0 & 0 & 0 & 0.13 & 0.07 & 313 & 180 & 13 & 8 & 6 & 4 & 938 & 786 \\
\hline 5 & $\begin{array}{l}\text { Liriodedron } \\
\text { tulipifera }\end{array}$ & 0.06 & 0.06 & 156 & 156 & 1 & 1 & 0.00 & 0.00 & 0 & 0 & 0 & 0 & 0.00 & 0.00 & 0 & 0 & 0 & 0 & 0 & 0 & 52 & 52 \\
\hline 5 & $\begin{array}{c}\text { Nyssa } \\
\text { sylvatica }\end{array}$ & 0.25 & 0.25 & 2656 & 2656 & 6 & 6 & 0.00 & 0.00 & 0 & 0 & 0 & 0 & 0.00 & 0.00 & 0 & 0 & 0 & 0 & 2 & 1 & 885 & 885 \\
\hline 5 & $\begin{array}{l}\text { Quercus } \\
\text { bicolor }\end{array}$ & 0.06 & 0.06 & 156 & 156 & 2 & 2 & 0.00 & 0.00 & 0 & 0 & 0 & 0 & 0.00 & 0.00 & 0 & 0 & 0 & 0 & 1 & 0 & 52 & 52 \\
\hline 5 & $\begin{array}{c}\text { Quercus } \\
\text { michauxii }\end{array}$ & 0.00 & 0.00 & 0 & 0 & 0 & 0 & 0.00 & 0.00 & 0 & 0 & 0 & 0 & 0.06 & 0.06 & 156 & 156 & 5 & 5 & 2 & 1 & 52 & 52 \\
\hline 5 & $\begin{array}{l}\text { Quercus } \\
\text { palustris }\end{array}$ & 0.25 & 0.10 & 1094 & 534 & 7 & 2 & 0.13 & 0.07 & 313 & 180 & 8 & 4 & 0.19 & 0.06 & 469 & 156 & 17 & 7 & 11 & 3 & 625 & 239 \\
\hline 5 & Ulmus rubra & 0.25 & 0.18 & 938 & 744 & 11 & 9 & 0.25 & 0.25 & 938 & 938 & 21 & 21 & 0.19 & 0.12 & 625 & 361 & 17 & 10 & 16 & 1 & 833 & 104 \\
\hline 5 & Unidentified & 0.00 & 0.00 & 0 & 0 & 0 & 0 & 0.00 & 0.00 & 0 & 0 & 0 & 0 & 0.06 & 0.06 & 156 & 156 & 5 & 5 & 2 & 1 & 52 & 52 \\
\hline 10 & Acer rubrum & 0.50 & 0.29 & 1875 & 1112 & 24 & 15 & 0.06 & 0.06 & 156 & 156 & 6 & 6 & 0.00 & 0.00 & 0 & 0 & 0 & 0 & 10 & 3 & 677 & 601 \\
\hline 10 & $\begin{array}{c}\text { Celtis } \\
\text { laevigata }\end{array}$ & 0.19 & 0.12 & 938 & 541 & 6 & 4 & 0.38 & 0.13 & 1719 & 738 & 46 & 11 & 0.06 & 0.06 & 156 & 156 & 4 & 4 & 19 & 12 & 938 & 451 \\
\hline 10 & $\begin{array}{c}\text { Fraxinus } \\
\text { pennsylvanica }\end{array}$ & 0.50 & 0.23 & 6563 & 5355 & 32 & 11 & 0.06 & 0.06 & 313 & 313 & 7 & 7 & 0.25 & 0.10 & 938 & 403 & 22 & 9 & 20 & 5 & 2604 & 1987 \\
\hline 10 & $\begin{array}{c}\text { Liquidambar } \\
\text { styraciflua }\end{array}$ & 0.19 & 0.19 & 1406 & 1406 & 5 & 5 & 0.00 & 0.00 & 0 & 0 & 0 & 0 & 0.06 & 0.06 & 156 & 156 & 8 & 8 & 4 & 2 & 521 & 445 \\
\hline 10 & $\begin{array}{c}\text { Nyssa } \\
\text { sylvatica }\end{array}$ & 0.19 & 0.19 & 2344 & 2344 & 6 & 6 & 0.00 & 0.00 & 0 & 0 & 0 & 0 & 0.00 & 0.00 & 0 & 0 & 0 & 0 & 2 & 1 & 781 & 781 \\
\hline 10 & Prunus spp. & 0.00 & 0.00 & 0 & 0 & 0 & 0 & 0.00 & 0.00 & 0 & 0 & 0 & 0 & 0.06 & 0.06 & 156 & 156 & 4 & 4 & 1 & 1 & 52 & 52 \\
\hline 10 & $\begin{array}{l}\text { Quercus } \\
\text { bicolor }\end{array}$ & 0.00 & 0.00 & 0 & 0 & 0 & 0 & 0.06 & 0.06 & 156 & 156 & 5 & 5 & 0.00 & 0.00 & 0 & 0 & 0 & 0 & 2 & 1 & 52 & 52 \\
\hline
\end{tabular}




\begin{tabular}{|c|c|c|c|c|c|c|c|c|c|c|c|c|c|c|c|c|c|c|c|c|c|c|c|}
\hline \multirow{3}{*}{$\begin{array}{c}\text { Dist. } \\
10\end{array}$} & \multirow{3}{*}{$\begin{array}{c}\text { Species } \\
\\
\text { Quercus } \\
\text { michauxii }\end{array}$} & \multicolumn{6}{|c|}{ Site 3: Wet Site } & \multicolumn{6}{|c|}{ Site 2: Intermediate } & \multicolumn{6}{|c|}{ Site 1: Dry Site } & \multicolumn{4}{|c|}{$\begin{array}{l}\text { Overall Means } \\
\text { (Across Sites) }\end{array}$} \\
\hline & & \multicolumn{2}{|c|}{$\begin{array}{c}\text { Mean } \\
\text { Freq. } \pm \\
\text { SE }\end{array}$} & \multicolumn{2}{|c|}{$\begin{array}{c}\text { Mean } \\
\text { Density } \pm \\
\text { SE }\end{array}$} & \multicolumn{2}{|c|}{$\begin{array}{c}\text { Mean IV } \\
\pm \mathrm{SE}\end{array}$} & \multicolumn{2}{|c|}{$\begin{array}{c}\text { Mean } \\
\text { Freq. } \pm \\
\text { SE }\end{array}$} & \multicolumn{2}{|c|}{$\begin{array}{c}\text { Mean } \\
\text { Density } \pm \text { SE }\end{array}$} & \multicolumn{2}{|c|}{$\begin{array}{c}\text { Mean IV } \\
\pm \mathrm{SE}\end{array}$} & \multicolumn{2}{|c|}{$\begin{array}{c}\text { Mean } \\
\text { Freq. } \pm \text { SE }\end{array}$} & \multicolumn{2}{|c|}{$\begin{array}{c}\text { Mean } \\
\text { Density } \pm \text { SE }\end{array}$} & \multicolumn{2}{|c|}{$\begin{array}{l}\text { Mean IV } \\
\pm \text { SE }\end{array}$} & \multicolumn{2}{|c|}{$\begin{array}{c}\text { Mean } \\
\mathrm{IV} \pm \\
\mathrm{SE}\end{array}$} & \multicolumn{2}{|c|}{$\begin{array}{c}\text { Mean } \\
\text { Density } \pm \\
\text { SE }\end{array}$} \\
\hline & & 0.00 & 0.00 & 0 & 0 & 0 & 0 & 0.00 & 0.00 & 0 & 0 & 0 & 0 & 0.13 & 0.13 & 313 & 313 & 6 & 6 & 2 & & 104 & 104 \\
\hline 10 & $\begin{array}{l}\text { Quercus } \\
\text { palustris }\end{array}$ & 0.19 & 0.06 & 469 & 156 & 18 & 11 & 0.19 & 0.06 & 625 & 255 & 17 & 6 & 0.19 & 0.19 & 781 & 781 & 11 & 11 & 15 & 2 & 625 & 90 \\
\hline 10 & Ulmus rubra & 0.13 & 0.13 & 469 & 469 & 7 & 7 & .13 & 0.07 & 313 & 180 & 19 & 12 & 0.25 & 0.10 & 781 & 299 & 20 & 8 & 15 & 1 & 521 & 138 \\
\hline 10 & Unidentified & 0.06 & 0.06 & 156 & 156 & 2 & 2 & 0.00 & 0.00 & 0 & 0 & 0 & 0 & 0.00 & 0.00 & 0 & 0 & 0 & 0 & 1 & 0 & 52 & 52 \\
\hline 30 & Acer rubrum & 0.25 & 0.10 & 938 & 313 & 36 & 22 & .00 & 0.00 & 0 & 0 & 0 & 0 & 0.06 & 0.06 & 156 & 156 & 8 & 8 & 15 & 4 & 365 & 290 \\
\hline 30 & $\begin{array}{c}\text { Asimina } \\
\text { triloba }\end{array}$ & 0.00 & 0.00 & 0 & 0 & 0 & 0 & 0.00 & 0.00 & 0 & 0 & 0 & 0 & 0.19 & 0.12 & 1250 & 884 & 24 & 14 & 8 & 7 & 417 & 417 \\
\hline 30 & $\begin{array}{c}\text { Celtis } \\
\text { laevigata }\end{array}$ & 0.00 & 0.00 & 0 & 0 & 0 & 0 & 0.63 & 0.24 & 4375 & 1943 & 43 & 16 & 0.19 & 0.06 & 469 & 156 & 25 & 9 & 23 & 6 & 1615 & 1387 \\
\hline 30 & $\begin{array}{c}\text { Fraxinus } \\
\text { pennsylvanica }\end{array}$ & 0.38 & 0.16 & 1875 & 1112 & 50 & 20 & 0.19 & 0.06 & 469 & 156 & 14 & 6 & 0.19 & 0.06 & 469 & 156 & 19 & 7 & 28 & 4 & 938 & 469 \\
\hline 30 & $\begin{array}{l}\text { Quercus } \\
\text { palustris }\end{array}$ & 0.13 & 0.07 & 313 & 180 & 8 & 5 & 0.38 & 0.16 & 1250 & 571 & 20 & 10 & 0.06 & 0.06 & 156 & 156 & 5 & 5 & 11 & 4 & 573 & 342 \\
\hline 30 & Ulmus rubra & 0.13 & 0.13 & 469 & 469 & 6 & 6 & 0.31 & 0.19 & 938 & 541 & 24 & 17 & 0.13 & 0.07 & 469 & 299 & 19 & 14 & 16 & 2 & 625 & 156 \\
\hline 60 & Acer rubrum & 0.31 & 0.24 & 938 & 744 & 20 & 17 & 0.00 & 0.00 & 0 & 0 & 0 & 0 & 0.00 & 0.00 & 0 & 0 & 0 & 0 & 7 & 2 & 313 & 313 \\
\hline 60 & $\begin{array}{c}\text { Asimina } \\
\text { triloba }\end{array}$ & 0.00 & 0.00 & 0 & 0 & 0 & 0 & 0.00 & 0.00 & 0 & 0 & 0 & 0 & 0.19 & 0.19 & 1094 & 1094 & 13 & 13 & 4 & 4 & 365 & 365 \\
\hline 60 & Carya spp. & 0.00 & 0.00 & 0 & 0 & 0 & 0 & 00 & 0 & 0 & 0 & 0 & 0 & 3 & 7 & 313 & 80 & 7 & 4 & 2 & 2 & 104 & 104 \\
\hline 60 & $\begin{array}{c}\text { Celtis } \\
\text { laevigata }\end{array}$ & 0.13 & 0.07 & 469 & 299 & 17 & 14 & 0.25 & 0.10 & 1875 & 807 & 54 & 21 & 0.13 & 0.13 & 469 & 469 & 9 & 9 & 27 & 13 & 938 & 469 \\
\hline 60 & $\begin{array}{l}\text { Diospyros } \\
\text { virginiana }\end{array}$ & 0.00 & 0.00 & 0 & 0 & 0 & 0 & 0.06 & 0.06 & 156 & 156 & 4 & 4 & 0.00 & 0.00 & 0 & 0 & 0 & 0 & 1 & 1 & 52 & 52 \\
\hline 60 & $\begin{array}{c}\text { Fraxinus } \\
\text { pennsylvanica }\end{array}$ & 0.19 & 0.12 & 1094 & 898 & 20 & 11 & 0.19 & 0.12 & 469 & 299 & 17 & 10 & 0.31 & 0.06 & 1406 & 393 & 32 & 7 & 23 & 4 & 990 & 276 \\
\hline 60 & $\begin{array}{l}\text { Liquidambar } \\
\text { styraciflua }\end{array}$ & 0.00 & 0.00 & 0 & 0 & 0 & 0 & 0.00 & 0.00 & 0 & 0 & 0 & 0 & 0.13 & 0.13 & 313 & 313 & 17 & 17 & 6 & 5 & 104 & 104 \\
\hline 60 & $\begin{array}{l}\text { Quercus } \\
\text { bicolor }\end{array}$ & 0.00 & 0.00 & 0 & 0 & 0 & 0 & 0.00 & 0.00 & 0 & 0 & 0 & 0 & 0.06 & 0.06 & 156 & 156 & 6 & 6 & 2 & 2 & 52 & 52 \\
\hline 60 & $\begin{array}{c}\text { Quercus } \\
\text { michauxii }\end{array}$ & 0.06 & 0.06 & 156 & 156 & 25 & 25 & 0.00 & 0.00 & 0 & 0 & 0 & 0 & 0.06 & 0.06 & 156 & 156 & 4 & 4 & 10 & 3 & 104 & 52 \\
\hline
\end{tabular}




\begin{tabular}{|c|c|c|c|c|c|c|c|c|c|c|c|c|c|c|c|c|c|c|c|c|c|}
\hline \multirow{3}{*}{$\begin{array}{c}\text { Dist. } \\
60 \\
6\end{array}$} & \multirow{3}{*}{\begin{tabular}{|l} 
Species \\
Quercus \\
palustris
\end{tabular}} & \multicolumn{5}{|c|}{ Site 3: Wet Site } & \multicolumn{5}{|c|}{ Site 2: Intermediate } & \multicolumn{6}{|c|}{ Site 1: Dry Site } & \multicolumn{4}{|c|}{$\begin{array}{l}\text { Overall Means } \\
\text { (Across Sites) }\end{array}$} \\
\hline & & $\begin{array}{l}\text { Mean } \\
\text { Freq. } \pm \\
\text { SE }\end{array}$ & \multicolumn{2}{|c|}{$\begin{array}{c}\text { Mean } \\
\text { Density } \pm \\
\text { SE }\end{array}$} & \multicolumn{2}{|c|}{$\begin{array}{c}\text { Mean IV } \\
\pm \text { SE }\end{array}$} & $\begin{array}{l}\text { Mean } \\
\text { Freq. } \pm \\
\text { SE }\end{array}$ & \multicolumn{2}{|c|}{$\begin{array}{c}\text { Mean } \\
\text { Density } \pm \text { SE }\end{array}$} & \multicolumn{2}{|c|}{$\begin{array}{c}\text { Mean IV } \\
\pm \mathrm{SE}\end{array}$} & \multicolumn{2}{|c|}{$\begin{array}{c}\text { Mean } \\
\text { Freq. } \pm \text { SE }\end{array}$} & \multicolumn{2}{|c|}{$\begin{array}{c}\text { Mean } \\
\text { Density } \pm \text { SE }\end{array}$} & \multicolumn{2}{|c|}{$\begin{array}{c}\text { Mean IV } \\
\pm \text { SE }\end{array}$} & \multicolumn{2}{|c|}{$\begin{array}{l}\text { Mean } \\
\text { IV } \pm \\
\text { SE }\end{array}$} & \multicolumn{2}{|c|}{$\begin{array}{c}\text { Mean } \\
\text { Density } \pm \\
\text { SE }\end{array}$} \\
\hline & & $0.25 \quad 0.14$ & 625 & 361 & 13 & 8 & $0.00 \quad 0.00$ & 0 & 0 & 0 & 0 & 0.06 & 0.06 & 156 & 156 & 4 & 4 & 6 & 2 & 260 & 188 \\
\hline 60 & Ulmus rubra & $0.13 \quad 0.13$ & 313 & 313 & 5 & 5 & $\begin{array}{ll}0.00 & 0.00\end{array}$ & 0 & 0 & 0 & 0 & 0.13 & 0.07 & 313 & 180 & 9 & 6 & 5 & 3 & 208 & 104 \\
\hline
\end{tabular}


Appendix Table 8. Results of mixed model regression testing for significance of fixed and random effects on species richness in the tree seedling stratum $(\mathrm{dbh}<0.3 \mathrm{~m})$. Modeled fixed effects were site, side (north vs. south edge), position (edge or interior location), 2 and 3 way interactions between these variables. Edge-to-interior transect (in table as EITransect) was included as a random effect, nested within each site and side.

\begin{tabular}{|c|c|c|c|c|c|c|c|c|c|c|}
\hline & \multicolumn{5}{|c|}{ Fixed Effects } & \multicolumn{5}{|c|}{ Random Effects } \\
\hline Response & Effect & $\begin{array}{c}\mathrm{Num} \\
\mathrm{DF}\end{array}$ & $\begin{array}{l}\text { Den } \\
\text { DF }\end{array}$ & $\begin{array}{c}\mathrm{F} \\
\text { Value }\end{array}$ & $\mathrm{p}$ & Covariance Parameter & Estimate & $\begin{array}{l}\text { Standard } \\
\text { Error }\end{array}$ & $\begin{array}{c}\mathrm{Z} \\
\text { Value }\end{array}$ & $\mathrm{p}$ \\
\hline \multirow{7}{*}{$\begin{array}{l}\text { Total } \\
\text { Stems }\end{array}$} & Site & 2 & 6 & 0.51 & 0.6227 & \multirow{7}{*}{$\begin{array}{c}\text { EITransect }(\text { Site*Side }) \\
\text { Scale }\end{array}$} & 0.5513 & 0.4121 & 1.34 & 0.0905 \\
\hline & Side & 1 & 6 & 4.37 & 0.0815 & & \multirow{6}{*}{0.5775} & \multirow[t]{6}{*}{0.1697} & \multirow[t]{6}{*}{3.4} & \multirow[t]{6}{*}{0.0003} \\
\hline & Distance from Edge & 1 & 41 & 3.75 & 0.0598 & & & & & \\
\hline & Site*Side & 2 & 6 & 1.49 & 0.2985 & & & & & \\
\hline & $\begin{array}{c}\text { Side*Distance from } \\
\text { Edge }\end{array}$ & 1 & 41 & 6.26 & 0.0164 & & & & & \\
\hline & $\begin{array}{c}\text { Site*Distance from } \\
\text { Edge }\end{array}$ & 2 & 41 & 1.41 & 0.2558 & & & & & \\
\hline & $\begin{array}{l}\text { Site*Side*Distance } \\
\text { from Edge }\end{array}$ & 2 & 41 & 0.39 & 0.6793 & & & & & \\
\hline \multirow[t]{7}{*}{ Richness } & Site & 2 & 6 & 0.41 & 0.6812 & \multirow[t]{7}{*}{ EITransect(Site*Side) } & \multirow[t]{7}{*}{0.1098} & \multirow[t]{7}{*}{0.1143} & \multirow[t]{7}{*}{0.96} & \multirow[t]{7}{*}{0.1685} \\
\hline & Side & 1 & 6 & 4.14 & 0.0881 & & & & & \\
\hline & Distance from Edge & 1 & 42 & 0.15 & 0.7019 & & & & & \\
\hline & Site*Side & 2 & 6 & 0.88 & 0.4617 & & & & & \\
\hline & $\begin{array}{c}\text { Side*Distance from } \\
\text { Edge }\end{array}$ & 1 & 42 & 2.23 & 0.1431 & & & & & \\
\hline & $\begin{array}{c}\text { Site*Distance from } \\
\text { Edge }\end{array}$ & 2 & 42 & 0.08 & 0.9227 & & & & & \\
\hline & $\begin{array}{l}\text { Site*Side*Distance } \\
\text { from Edge }\end{array}$ & 2 & 42 & 0.15 & 0.8618 & & & & & \\
\hline
\end{tabular}


Appendix Table 9. Mean frequencies, densities and IV values for all tree seedlings at varying distances from the forest edge (in meters), at each site, and across sites. The highest density and IV values at each distance and site (and across sites) are in bold.

\begin{tabular}{|c|c|c|c|c|c|c|c|c|c|c|c|c|c|c|c|c|c|c|c|c|c|c|c|}
\hline \multirow{3}{*}{$\begin{array}{c}\text { Dist. } \\
\\
1\end{array}$} & \multirow{3}{*}{$\begin{array}{l}\text { Species } \\
\text { Acer spp. }\end{array}$} & \multicolumn{6}{|c|}{ Site 3: Wet Site } & \multicolumn{6}{|c|}{ Site 2: Intermediate Site } & \multicolumn{6}{|c|}{ Site 1: Dry Site } & \multicolumn{4}{|c|}{ Across Sites } \\
\hline & & \multicolumn{2}{|c|}{$\begin{array}{c}\text { Mean } \\
\text { Freq. } \pm \text { SE }\end{array}$} & \multicolumn{2}{|c|}{$\begin{array}{c}\text { Mean } \\
\text { Density } \\
\text { (stems/ha) } \\
\pm \mathrm{SE}\end{array}$} & \multicolumn{2}{|c|}{$\begin{array}{c}\text { Mean } \\
\text { IV } \\
\pm S E\end{array}$} & \multicolumn{2}{|c|}{$\begin{array}{c}\text { Mean } \\
\text { Freq. } \pm \text { SE }\end{array}$} & \multicolumn{2}{|c|}{$\begin{array}{c}\text { Mean Density (stems/ha) } \\
\pm \mathrm{SE}\end{array}$} & \multicolumn{2}{|c|}{$\begin{array}{c}\text { Mean } \\
\text { IV } \\
\pm \text { SE }\end{array}$} & \multicolumn{2}{|c|}{$\begin{array}{c}\text { Mean } \\
\text { Freq. } \pm \text { SE }\end{array}$} & \multicolumn{2}{|c|}{$\begin{array}{c}\text { Mean } \\
\text { Density } \\
\text { (stems/ha) } \\
\pm \mathrm{SE}\end{array}$} & \multicolumn{2}{|c|}{$\begin{array}{c}\text { Mean } \\
\text { IV } \\
\pm \text { SE }\end{array}$} & \multicolumn{2}{|c|}{$\begin{array}{c}\text { Mean } \\
\text { Density } \\
\text { (stems/ha) } \\
\pm \mathrm{SE}\end{array}$} & \multicolumn{2}{|c|}{$\begin{array}{c}\text { Mean } \\
\text { IV } \\
\pm \text { SE }\end{array}$} \\
\hline & & 0.06 & 0.06 & 156 & 156 & 13 & 13 & 0.00 & 0.00 & 0 & 0 & 0 & & 0.00 & 0.00 & 0 & 0 & 0 & & 52 & 52 & 4 & 4 \\
\hline 1 & $\begin{array}{c}\text { Celtis } \\
\text { laevigata }\end{array}$ & 0.06 & 0.06 & 156 & 156 & 10 & 10 & 0.13 & 0.07 & 469 & 299 & 15 & 8 & 0.13 & 0.07 & 313 & 180 & 33 & 24 & 313 & 90 & 19 & 7 \\
\hline 1 & $\begin{array}{c}\text { Fraxinus } \\
\text { pennsylvanica }\end{array}$ & 0.19 & 0.06 & 1406 & 822 & 44 & 22 & 0.19 & 0.06 & 4063 & 3447 & 41 & 15 & 0.06 & 0.06 & 313 & 313 & 7 & 7 & 1927 & 1113 & 31 & 12 \\
\hline 1 & $\begin{array}{l}\text { Liquidambar } \\
\text { styraciflua }\end{array}$ & 0.06 & 0.06 & 469 & 469 & 8 & 8 & 0.00 & 0.00 & 0 & 0 & 0 & 0 & 0.06 & 0.06 & 313 & 313 & 7 & 7 & 260 & 138 & 5 & 3 \\
\hline 1 & $\begin{array}{l}\text { Quercus } \\
\text { palustris }\end{array}$ & 0.06 & 0.06 & 313 & 313 & 7 & 7 & 0.13 & 0.07 & 313 & 180 & 20 & 12 & 0.06 & 0.06 & 156 & 156 & 8 & 8 & 260 & 52 & 12 & 4 \\
\hline 1 & Rosaceae & 0.00 & 0.00 & 0 & 0 & 0 & 0 & 0.00 & 0.00 & 0 & 0 & 0 & 0 & 0.06 & 0.06 & 156 & 156 & 5 & 5 & 52 & 52 & 2 & 2 \\
\hline 1 & Ulmus rubra & 0.13 & 0.07 & 313 & 180 & 17 & 12 & 0.00 & 0.00 & 0 & 0 & 0 & 0 & 0.06 & 0.06 & 156 & 156 & 5 & 5 & 156 & 90 & 8 & 5 \\
\hline 1 & Unidentified & 0.00 & 0.00 & 0 & 0 & 0 & 0 & 0.00 & 0.00 & 0 & 0 & 0 & 0 & 0.06 & 0.06 & 156 & 156 & 8 & 8 & 52 & 52 & 3 & 3 \\
\hline 5 & Acer spp. & 0.06 & 0.06 & 156 & 156 & 6 & 6 & 0.00 & 0.00 & 0 & 0 & 0 & 0 & 0.00 & 0.00 & 0 & 0 & 0 & 0 & 52 & 52 & 2 & 2 \\
\hline 5 & Carya sp. & 0.00 & 0.00 & 0 & 0 & 0 & 0 & 0.00 & 0.00 & 0 & 0 & 0 & 0 & 0.06 & 0.06 & 156 & 156 & 13 & 13 & 52 & 52 & 4 & 4 \\
\hline 5 & $\begin{array}{c}\text { Celtis } \\
\text { laevigata }\end{array}$ & 0.00 & 0.00 & 0 & 0 & 0 & 0 & 0.13 & 0.07 & 938 & 598 & 24 & 14 & 0.06 & 0.06 & 625 & 625 & 7 & 7 & 521 & 276 & 10 & 7 \\
\hline 5 & $\begin{array}{l}\text { Diospyros } \\
\text { virginiana }\end{array}$ & 0.00 & 0.00 & 0 & 0 & 0 & 0 & 0.06 & 0.06 & 156 & 156 & 6 & 6 & 0.00 & 0.00 & 0 & 0 & 0 & 0 & 52 & 52 & 2 & 2 \\
\hline 5 & $\begin{array}{c}\text { Fraxinus } \\
\text { pennsylvanica }\end{array}$ & 0.13 & 0.07 & 2813 & 2065 & 24 & 14 & 0.13 & 0.07 & 625 & 442 & 39 & 24 & 0.19 & 0.06 & 2656 & 2047 & 63 & 24 & 2031 & 705 & 42 & 11 \\
\hline 5 & $\begin{array}{c}\text { Liquidambar } \\
\text { styraciflua }\end{array}$ & 0.06 & 0.06 & 469 & 469 & 5 & 5 & 0.00 & 0.00 & 0 & 0 & 0 & 0 & 0.06 & 0.06 & 156 & 156 & 13 & 13 & 208 & 138 & 6 & 4 \\
\hline 5 & $\begin{array}{l}\text { Nyssa } \\
\text { sylvatica }\end{array}$ & 0.13 & 0.07 & 313 & 180 & 29 & 24 & 0.00 & 0.00 & 0 & 0 & 0 & 0 & 0.00 & 0.00 & 0 & 0 & 0 & 0 & 104 & 104 & 10 & 10 \\
\hline
\end{tabular}




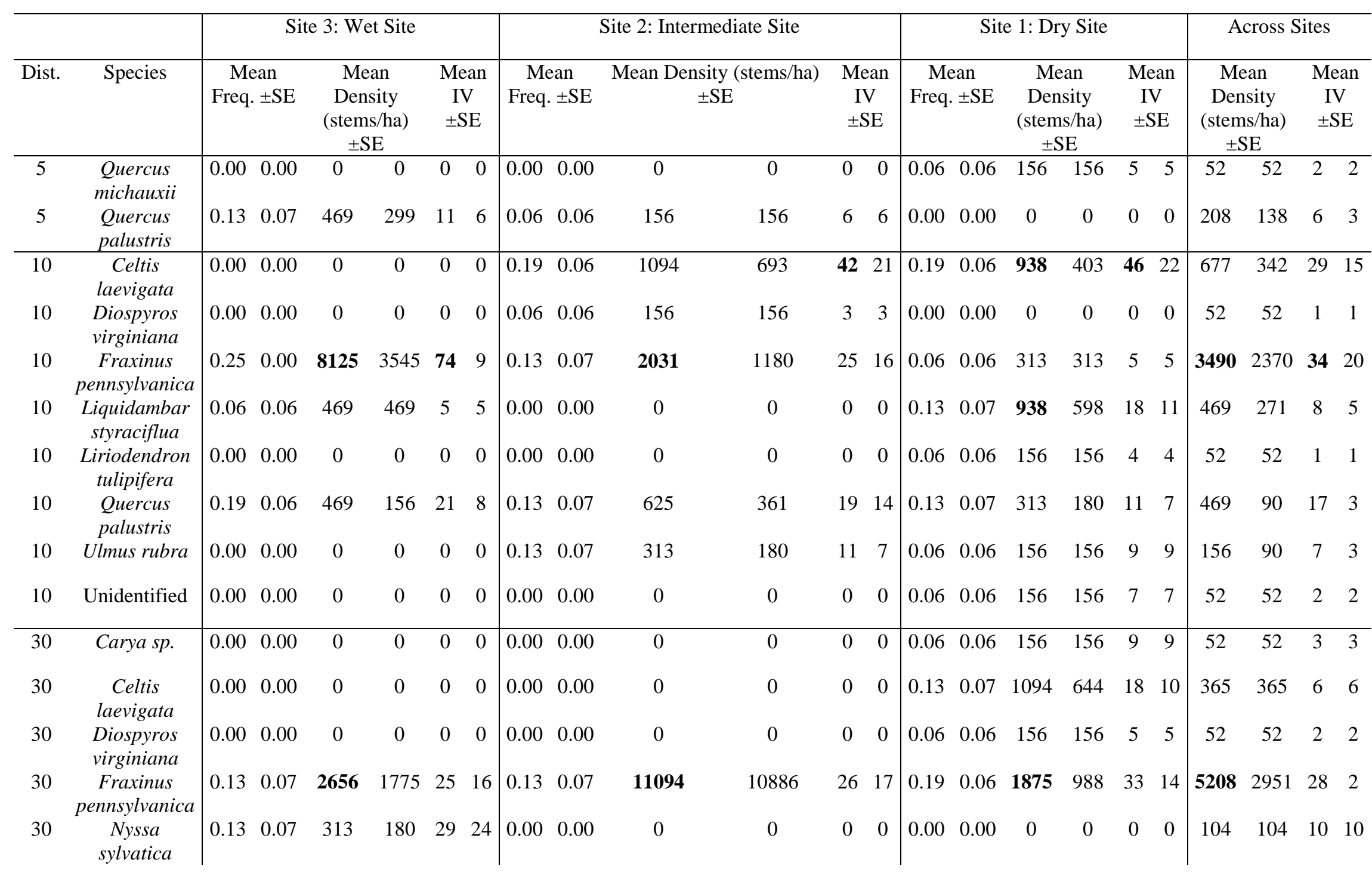




\begin{tabular}{|c|c|c|c|c|c|c|c|c|c|c|c|c|c|c|c|c|c|c|c|c|c|c|c|}
\hline \multirow{3}{*}{$\begin{array}{c}\text { Dist. } \\
\\
30\end{array}$} & \multirow{3}{*}{$\begin{array}{c}\text { Species } \\
\text { Prunus spp. }\end{array}$} & \multicolumn{6}{|c|}{ Site 3: Wet Site } & \multicolumn{6}{|c|}{ Site 2: Intermediate Site } & \multicolumn{6}{|c|}{ Site 1: Dry Site } & \multicolumn{4}{|c|}{ Across Sites } \\
\hline & & \multirow{2}{*}{\multicolumn{2}{|c|}{$\begin{array}{c}\text { Mean } \\
\text { Freq. } \pm \text { SE } \\
0.00 \quad 0.00\end{array}$}} & \multicolumn{2}{|c|}{$\begin{array}{c}\text { Mean } \\
\text { Density } \\
\text { (stems/ha) } \\
\pm \text { SE }\end{array}$} & \multicolumn{2}{|c|}{$\begin{array}{l}\text { Mean } \\
\text { IV } \\
\pm \text { SE }\end{array}$} & \multicolumn{2}{|c|}{$\begin{array}{c}\text { Mean } \\
\text { Freq. } \pm \text { SE }\end{array}$} & \multicolumn{2}{|c|}{$\begin{array}{c}\text { Mean Density (stems/ha) } \\
\pm \mathrm{SE}\end{array}$} & \multicolumn{2}{|c|}{$\begin{array}{c}\text { Mean } \\
\text { IV } \\
\pm \text { SE }\end{array}$} & \multicolumn{2}{|c|}{$\begin{array}{c}\text { Mean } \\
\text { Freq. } \pm \mathrm{SE}\end{array}$} & \multicolumn{2}{|c|}{$\begin{array}{c}\text { Mean } \\
\text { Density } \\
\text { (stems/ha) } \\
\pm \text { SE } \\
\end{array}$} & \multicolumn{2}{|c|}{$\begin{array}{c}\text { Mean } \\
\text { IV } \\
\pm \text { SE }\end{array}$} & \multicolumn{2}{|c|}{$\begin{array}{c}\text { Mean } \\
\text { Density } \\
\text { (stems/ha) } \\
\pm \text { SE } \\
\end{array}$} & \multicolumn{2}{|c|}{$\begin{array}{c}\text { Mean } \\
\text { IV } \\
\pm \text { SE }\end{array}$} \\
\hline & & & & 0 & 0 & 0 & 0 & 0.06 & 0.06 & 156 & 156 & 8 & 8 & 0.00 & 0.00 & 0 & 0 & 0 & & 52 & 52 & 3 & 3 \\
\hline 30 & $\begin{array}{l}\text { Quercus } \\
\text { michauxii }\end{array}$ & 0.00 & 0.00 & 0 & 0 & 0 & 0 & 0.00 & 0.00 & 0 & 0 & 0 & 0 & 0.13 & 0.07 & 313 & 180 & 14 & 9 & 104 & 104 & 5 & 5 \\
\hline 30 & $\begin{array}{l}\text { Quercus } \\
\text { palustris }\end{array}$ & 0.19 & 0.06 & 2188 & 1409 & 41 & 21 & 0.13 & 0.07 & 469 & 299 & 33 & 24 & 0.06 & 0.06 & 469 & 469 & 16 & 16 & 1042 & 573 & 30 & 8 \\
\hline 30 & Ulmus rubra & 0.06 & 0.06 & 625 & 625 & 5 & 5 & 0.06 & 0.06 & 938 & 938 & 7 & 7 & 0.06 & 0.06 & 156 & 156 & 5 & 5 & 573 & 227 & 6 & 1 \\
\hline 60 & $\begin{array}{c}\text { Asimina } \\
\text { triloba }\end{array}$ & 0.00 & 0.00 & 0 & 0 & 0 & 0 & 0.00 & 0.00 & 0 & 0 & 0 & 0 & 0.06 & 0.06 & 156 & 156 & 5 & 5 & 52 & 52 & 2 & 2 \\
\hline 60 & $\begin{array}{c}\text { Celtis } \\
\text { laevigata }\end{array}$ & 0.00 & 0.00 & 0 & 0 & 0 & 0 & 0.19 & 0.06 & 625 & 255 & 43 & 22 & 0.13 & 0.07 & 625 & 361 & 19 & 12 & 417 & 208 & 21 & 13 \\
\hline 60 & $\begin{array}{c}\text { Fraxinus } \\
\text { pennsylvanica }\end{array}$ & 0.25 & 0.00 & 10938 & 5440 & 71 & 12 & 0.13 & 0.07 & 5625 & 3489 & 33 & 19 & 0.13 & 0.07 & 781 & 469 & 21 & 13 & 5781 & 2933 & 41 & 15 \\
\hline 60 & $\begin{array}{l}\text { Liquidambar } \\
\text { styraciflua }\end{array}$ & 0.06 & 0.06 & 156 & 156 & 3 & 3 & 0.00 & 0.00 & 0 & 0 & 0 & 0 & 0.00 & 0.00 & 0 & 0 & 0 & 0 & 52 & 52 & 1 & 1 \\
\hline 60 & Prunus spp. & 0.00 & 0.00 & 0 & 0 & 0 & 0 & 0.00 & 0.00 & 0 & 0 & 0 & 0 & 0.06 & 0.06 & 156 & 156 & 25 & 25 & 52 & 52 & 8 & 8 \\
\hline 60 & $\begin{array}{l}\text { Quercus } \\
\text { palustris }\end{array}$ & 0.19 & 0.06 & 2500 & 2089 & 22 & 7 & 0.13 & 0.07 & 313 & 180 & 19 & 12 & 0.00 & 0.00 & 0 & 0 & 0 & 0 & 938 & 786 & 14 & 7 \\
\hline 60 & Ulmus rubra & 0.06 & 0.06 & 313 & 313 & 4 & 4 & 0.06 & 0.06 & 156 & 156 & 5 & 5 & 0.13 & 0.07 & 313 & 180 & 30 & 24 & 260 & 52 & 13 & 9 \\
\hline
\end{tabular}


Appendix Table 10. Results of mixed model regression testing for significance of fixed and random effects on shrub species richness. Modeled fixed effects were site, side (north vs. south edge), position (edge or interior location), 2 and 3 way interactions between these variables. Edge-to-interior transect (in table as EITransect) was included as a random effect, nested within site. Post-hoc pairwise comparisons of L. japonica cover between research sites are shown at the bottom. Adjusted $\mathrm{P}$ values were calculated using the Tukey-Kramer method.

\begin{tabular}{|c|c|c|c|c|c|c|c|c|c|c|}
\hline & \multicolumn{5}{|c|}{ Fixed Effects } & \multicolumn{5}{|c|}{ Random Effects } \\
\hline $\begin{array}{l}\text { Response } \\
\text { Variable }\end{array}$ & Effect & $\begin{array}{l}\text { Num } \\
\text { DF }\end{array}$ & Den DF & $\begin{array}{c}\mathrm{F} \\
\text { Value }\end{array}$ & $\mathrm{p}$ & $\begin{array}{l}\text { Covariance } \\
\text { Parameter }\end{array}$ & Estimate & $\begin{array}{l}\text { Standard } \\
\text { Error }\end{array}$ & $\begin{array}{c}\mathrm{Z} \\
\text { Value }\end{array}$ & \\
\hline Species Richness & Site & 2 & 9 & 10.26 & 0.0048 & $\begin{array}{l}\text { EITransect(Site) } \\
\text { Scale }\end{array}$ & $\begin{array}{r}0.008172 \\
0.3821\end{array}$ & $\begin{array}{r}0.07565 \\
0.1436\end{array}$ & $\begin{array}{l}0.11 \\
2.66\end{array}$ & $\begin{array}{r}0.457 \\
0.0039\end{array}$ \\
\hline
\end{tabular}

Between Site Comparisons: Differences of Least Squares Means

\begin{tabular}{|c|c|c|c|c|c|c|c|c|}
\hline Effect & Site & Site & Estimate & SE & DF & t Value & $\mathrm{p}$ & Adj P \\
\hline Site & 2 & 1 & -1.151 & 0.2666 & 9 & -4.32 & 0.0019 & 0.005 \\
\hline Site & 2 & 3 & -0.379 & 0.2813 & 9 & -1.35 & 0.2105 & 0.4059 \\
\hline Site & 1 & 3 & 0.7715 & 0.2533 & 9 & 3.05 & 0.0139 & 0.0337 \\
\hline
\end{tabular}


Appendix Table 11. Mean frequencies, percent cover and IV values for all vine species at varying distance from the forest edge, at each site, and across sites. Bold values indicate the highest mean stem density or IV at each combination of distance and site. In the "Across Sites" column, the highest mean IV and stem density for species occurring at all sites is in bold.

\begin{tabular}{|c|c|c|c|c|c|c|c|c|c|c|c|c|c|c|c|c|c|c|c|c|c|c|c|}
\hline \multirow{3}{*}{$\begin{array}{c}\text { Dist. } \\
\\
1\end{array}$} & \multirow{3}{*}{$\begin{array}{l}\text { Species } \\
\text { ralia spinosa }\end{array}$} & \multicolumn{6}{|c|}{ Site 3} & \multicolumn{6}{|c|}{ Site 2} & \multicolumn{6}{|c|}{ Site 1} & \multicolumn{4}{|c|}{ Across Sites } \\
\hline & & \multicolumn{2}{|c|}{$\begin{array}{c}\text { Mean } \\
\text { Freq. } \pm \text { SE }\end{array}$} & \multicolumn{2}{|c|}{$\begin{array}{c}\text { Mean Density } \\
\text { (stems/ha) } \\
\pm \mathrm{SE}\end{array}$} & \multicolumn{2}{|c|}{$\begin{array}{l}\text { Mean } \\
\text { IV } \\
\pm \text { SE }\end{array}$} & \multicolumn{2}{|c|}{$\begin{array}{c}\text { Mean } \\
\text { Freq. } \pm \text { SE }\end{array}$} & \multicolumn{2}{|c|}{$\begin{array}{c}\text { Mean Density } \\
\text { (stems/ha) } \\
\pm \mathrm{SE}\end{array}$} & \multicolumn{2}{|c|}{$\begin{array}{c}\text { Mean } \\
\text { IV } \\
\pm \mathrm{SE}\end{array}$} & \multicolumn{2}{|c|}{$\begin{array}{c}\text { Mean } \\
\text { Freq. } \pm \text { SE }\end{array}$} & \multicolumn{2}{|c|}{$\begin{array}{c}\text { Mean } \\
\text { Density } \\
\text { (stems/ha) } \\
\pm \text { SE }\end{array}$} & \multicolumn{2}{|c|}{$\begin{array}{l}\text { Mean } \\
\text { IV } \\
\pm \text { SE }\end{array}$} & \multicolumn{2}{|c|}{$\begin{array}{l}\text { Mean Density } \\
\text { (stems/ha) } \pm \text { SE }\end{array}$} & \multicolumn{2}{|c|}{$\begin{array}{c}\text { Mean } \\
\text { IV } \\
\pm \text { SE }\end{array}$} \\
\hline & & 0.06 & 0.06 & 469 & 469 & 2 & 2 & 0.00 & 0.00 & 0 & 0 & 0 & & 0.00 & 0.00 & 0 & 0 & 0 & & 156 & 156 & 1 & \\
\hline 1 & $\begin{array}{c}\text { Cephalanthus } \\
\text { occidentalis }\end{array}$ & 0.13 & 0.07 & 469 & 299 & 12 & 10 & 0.00 & 0.00 & 0 & 0 & 0 & 0 & 0.00 & 0.00 & 0 & 0 & 0 & 0 & 156 & 100 & 4 & 3 \\
\hline 1 & Cornus foemina & 0.31 & 0.16 & 2031 & 1621 & 30 & 19 & 0.00 & 0.00 & 0 & 0 & 0 & 0 & 0.00 & 0.00 & 0 & 0 & 0 & 0 & 677 & 540 & 10 & 6 \\
\hline 1 & $\begin{array}{l}\text { Euonymus } \\
\text { alatus }\end{array}$ & 0.00 & 0.00 & 0 & 0 & 0 & 0 & 0.00 & 0.00 & 0 & 0 & 0 & 0 & 0.06 & 0.06 & 469 & 469 & 3 & 3 & 156 & 156 & 1 & 1 \\
\hline 1 & Lindera benzoin & 0.00 & 0.00 & 0 & 0 & 0 & 0 & 0.00 & 0.00 & 0 & 0 & 0 & 0 & 0.63 & 0.24 & 5313 & 2558 & 23 & 10 & 1771 & 853 & 8 & 3 \\
\hline 1 & $\begin{array}{c}\text { Lonicera } \\
\text { maackii }\end{array}$ & 0.19 & 0.12 & 781 & 592 & 11 & 7 & 0.00 & 0.00 & 0 & 0 & 0 & 0 & 0.38 & 0.22 & 4219 & 2466 & 17 & 11 & 1667 & 743 & 9 & 3 \\
\hline 1 & Rosa spp. & 0.00 & 0.00 & 0 & 0 & 0 & 0 & 0.00 & 0.00 & 0 & 0 & 0 & 0 & 0.06 & 0.06 & 781 & 781 & 2 & 2 & 260 & 260 & 1 & 1 \\
\hline 1 & Rubus spp. & 0.19 & 0.19 & 5469 & 5469 & 14 & 14 & 0.25 & 0.14 & 3594 & 2259 & 50 & 29 & 0.75 & 0.14 & 12031 & 3639 & 55 & 16 & 7031 & 930 & 39 & 5 \\
\hline 1 & $\begin{array}{l}\text { Sambucus } \\
\text { canadensis }\end{array}$ & 0.06 & 0.06 & 156 & 156 & 2 & 2 & 0.00 & 0.00 & 0 & 0 & 0 & 0 & 0.00 & 0.00 & 0 & 0 & 0 & 0 & 52 & 52 & 1 & 1 \\
\hline 1 & $\begin{array}{c}\text { Symphoricarpos } \\
\text { orbiculatus }\end{array}$ & 0.06 & 0.06 & 156 & 156 & 4 & 4 & 0.00 & 0.00 & 0 & 0 & 0 & 0 & 0.06 & 0.06 & 156 & 156 & 1 & 1 & 104 & 52 & 2 & 1 \\
\hline 5 & $\begin{array}{l}\text { Cephalanthus } \\
\text { occidentalis }\end{array}$ & 0.13 & 0.07 & 469 & 299 & 7 & 5 & 0.00 & 0.00 & 0 & 0 & 0 & 0 & 0.00 & 0.00 & 0 & 0 & 0 & 0 & 156 & 100 & 2 & 2 \\
\hline 5 & Cornus foemina & 0.50 & 0.14 & 13438 & 10994 & 85 & 9 & 0.06 & 0.06 & 469 & 469 & 3 & 3 & 0.13 & 0.13 & 2031 & 2031 & 7 & 7 & 5313 & 3279 & 32 & 2 \\
\hline 5 & Lindera benzoin & 0.00 & 0.00 & 0 & 0 & 0 & 0 & 0.00 & 0.00 & 0 & 0 & 0 & 0 & 0.56 & 0.21 & 7969 & 4659 & 28 & 12 & 2656 & 1553 & 9 & 4 \\
\hline 5 & $\begin{array}{c}\text { Lonicera } \\
\text { maackii }\end{array}$ & 0.00 & 0.00 & 0 & 0 & 0 & 0 & 0.63 & 0.16 & 10000 & 3197 & 75 & 15 & 0.31 & 0.19 & 2500 & 1926 & 11 & 7 & 4167 & 929 & 29 & 4 \\
\hline 5 & Rosa spp. & 0.00 & 0.00 & 0 & 0 & 0 & 0 & 0.00 & 0.00 & 0 & 0 & 0 & 0 & 0.13 & 0.13 & 4375 & 4375 & 12 & 12 & 1458 & 1458 & 4 & 4 \\
\hline 5 & Rubus spp. & 0.19 & 0.19 & 2969 & 2969 & 8 & 8 & 0.25 & 0.14 & 1719 & 1180 & 21 & 14 & 0.19 & 0.12 & 2188 & 1985 & 9 & 7 & 2292 & 517 & 13 & 2 \\
\hline 5 & $\begin{array}{l}\text { Sambucus } \\
\text { canadensis }\end{array}$ & 0.00 & 0.00 & 0 & 0 & 0 & 0 & 0.00 & 0.00 & 0 & 0 & 0 & 0 & 0.13 & 0.13 & 781 & 781 & 4 & 4 & 260 & 260 & 1 & 1 \\
\hline 5 & Unidentified & 0.00 & 0.00 & 0 & 0 & 0 & 0 & 0.00 & 0.00 & 0 & 0 & 0 & 0 & 0.06 & 0.06 & 938 & 938 & 3 & 3 & 313 & 313 & 1 & 1 \\
\hline
\end{tabular}




\begin{tabular}{|c|c|c|c|c|c|c|c|c|c|c|c|c|c|c|c|c|c|c|c|c|c|c|c|}
\hline \multirow{3}{*}{$\begin{array}{c}\text { Dist. } \\
10\end{array}$} & \multirow{3}{*}{$\begin{array}{c}\begin{array}{c}\text { Appendix Table } 11 \\
\text { (cont'd) }\end{array} \\
\text { Species } \\
\\
\begin{array}{c}\text { Cephalanthus } \\
\text { occidentalis }\end{array}\end{array}$} & \multicolumn{6}{|c|}{ Site 3: Wet Site } & \multicolumn{6}{|c|}{ Site 2: Intermediate Site } & \multicolumn{6}{|c|}{ Site 1: Dry Site } & \multicolumn{4}{|c|}{ Across Sites } \\
\hline & & \multicolumn{2}{|c|}{$\begin{array}{c}\text { Mean } \\
\text { Freq. } \pm \text { SE }\end{array}$} & \multicolumn{2}{|c|}{$\begin{array}{c}\text { Mean } \\
\text { Density } \\
\text { (stems/ha) } \\
\pm \mathrm{SE}\end{array}$} & \multicolumn{2}{|c|}{$\begin{array}{l}\text { Mean } \\
\text { IV } \\
\pm \text { SE }\end{array}$} & \multicolumn{2}{|c|}{$\begin{array}{c}\text { Mean } \\
\text { Freq. } \pm \text { SE }\end{array}$} & \multicolumn{2}{|c|}{$\begin{array}{c}\text { Mean Density } \\
\text { (stems/ha) } \\
\quad \pm \mathrm{SE}\end{array}$} & \multicolumn{2}{|c|}{$\begin{array}{l}\text { Mean } \\
\text { IV } \\
\pm \text { SE }\end{array}$} & \multicolumn{2}{|c|}{$\begin{array}{l}\text { Mean } \\
\text { Freq. } \pm \text { SE }\end{array}$} & \multicolumn{2}{|c|}{$\begin{array}{c}\text { Mean } \\
\text { Density } \\
\text { (stems/ha) } \\
\pm \text { SE }\end{array}$} & \multicolumn{2}{|c|}{$\begin{array}{c}\text { Mean } \\
\text { IV } \\
\pm S E\end{array}$} & \multicolumn{2}{|c|}{$\begin{array}{l}\text { Mean Density } \\
\text { (stems/ha) } \pm \text { SE }\end{array}$} & \multicolumn{2}{|c|}{$\begin{array}{c}\text { Mean } \\
\text { IV } \\
\pm \text { SE }\end{array}$} \\
\hline & & 0.13 & 0.13 & 469 & 469 & 12 & 12 & 0.00 & 0.00 & 0 & 0 & 0 & 0 & 0.00 & 0.00 & 0 & 0 & 0 & 0 & 156 & 156 & 4 & 4 \\
\hline 10 & Cornus foemina & 0.13 & 0.13 & 625 & 625 & 13 & 13 & 0.00 & 0.00 & 0 & 0 & 0 & 0 & 0.00 & 0.00 & 0 & 0 & 0 & 0 & 208 & 208 & 4 & 4 \\
\hline 10 & $\begin{array}{l}\text { Euonymus } \\
\text { americanus }\end{array}$ & 0.00 & 0.00 & 0 & 0 & 0 & 0 & 0.00 & 0.00 & 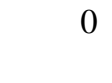 & 0 & 0 & 0 & 0.06 & 0.06 & 469 & 469 & 2 & 2 & 156 & 156 & 1 & 1 \\
\hline 10 & Lindera benzoin & 0.00 & 0.00 & 0 & 0 & 0 & 0 & 0.00 & 0.00 & 0 & 0 & 0 & 0 & 0.75 & 0.18 & 13125 & 5846 & 58 & 9 & 4375 & 1949 & 19 & 3 \\
\hline 10 & Lonicera maackii & 0.00 & 0.00 & 0 & 0 & 0 & 0 & 0.56 & 0.12 & 6875 & 3217 & 92 & 8 & 0.38 & 0.16 & 3438 & 1624 & 24 & 11 & 3438 & 929 & 38 & 3 \\
\hline 10 & Rubus spp. & 0.00 & 0.00 & 0 & 0 & 0 & 0 & 0.06 & 0.06 & 469 & 469 & 8 & 8 & 0.19 & 0.19 & 4219 & 4219 & 10 & 10 & 1563 & 1335 & 6 & 3 \\
\hline 10 & $\begin{array}{l}\text { Sambucus } \\
\text { canadensis }\end{array}$ & 0.00 & 0.00 & 0 & 0 & 0 & 0 & 0.00 & 0.00 & 0 & 0 & 0 & 0 & 0.06 & 0.06 & 156 & 156 & 2 & 2 & 52 & 52 & 1 & 1 \\
\hline 10 & Unidentified & 0.00 & 0.00 & 0 & 0 & 0 & 0 & 0.00 & 0.00 & 0 & 0 & 0 & 0 & 0.06 & 0.06 & 469 & 469 & 5 & 5 & 156 & 156 & 2 & 2 \\
\hline 30 & Cornus foemina & 0.19 & 0.06 & 4688 & 3172 & 32 & 11 & 0.31 & 0.16 & 3906 & 2316 & 31 & 15 & 0.00 & 0.12 & 2969 & 2215 & 7 & 5 & 3854 & 303 & 24 & 3 \\
\hline 30 & Lindera benzoin & 0.00 & 0.00 & 0 & 0 & 0 & 0 & 0.00 & 0.00 & 0 & 0 & 0 & 0 & 0.75 & 0.18 & 16094 & 7673 & 46 & 15 & 5365 & 2558 & 15 & 5 \\
\hline 30 & Lonicera maackii & 0.19 & 0.12 & 1094 & 644 & 29 & 17 & 0.31 & 0.12 & 5469 & 2171 & 44 & 18 & 0.38 & 0.16 & 8125 & 5007 & 20 & 10 & 4896 & 1278 & 31 & 2 \\
\hline 30 & Prunus sp. & 0.00 & 0.00 & 0 & 0 & 0 & 0 & 0.00 & 0.00 & 0 & 0 & 0 & 0 & 0.06 & 0.06 & 156 & 156 & 2 & 0 & 52 & 52 & 1 & 1 \\
\hline 30 & Rosa spp. & 0.06 & 0.06 & 781 & 781 & 5 & 5 & 0.00 & 0.00 & 0 & 0 & 0 & 0 & 0.00 & 0.00 & 0 & 0 & 0 & U & 260 & 260 & 2 & 2 \\
\hline 30 & Rubus spp. & 0.13 & 0.13 & 1250 & 1250 & 9 & 9 & 0.00 & 0.00 & 0 & 0 & 0 & 0 & 0.56 & 0.16 & 3438 & 1263 & 23 & 7 & 1563 & 419 & 11 & 3 \\
\hline 30 & $\begin{array}{l}\text { Sambucus } \\
\text { canadensis }\end{array}$ & 0.00 & 0.00 & 0 & 0 & 0 & 0 & 0.00 & 0.00 & 0 & 0 & 0 & 0 & 0.06 & 0.06 & 156 & 156 & 1 & 1 & 52 & 52 & 0 & 0 \\
\hline 60 & Cornus foemina & 0.31 & 0.24 & 9375 & 9168 & 30 & 24 & 0.38 & 0.22 & 12500 & 10861 & 71 & 24 & 0.06 & 0.06 & 156 & 156 & 2 & 2 & 7344 & 3322 & 34 & 7 \\
\hline 60 & Euonymus alatus & 0.00 & 0.00 & 0 & 0 & 0 & 0 & 0.00 & 0.00 & 0 & 0 & 0 & 0 & 0.06 & 0.06 & 1094 & 1094 & 3 & 5 & 365 & 365 & 1 & 1 \\
\hline 60 & Lindera benzoin & 0.00 & 0.00 & 0 & 0 & 0 & 0 & 0.00 & 0.00 & 0 & 0 & 0 & 0 & 0.88 & 0.07 & 16719 & 2880 & 55 & 2 & 5573 & 960 & 18 & 1 \\
\hline 60 & Lonicera maackii & 0.13 & 0.13 & 2188 & 2188 & 20 & 20 & 0.06 & 0.06 & 1875 & 1875 & 4 & 4 & 0.50 & 0.00 & 3750 & 884 & 22 & 3 & 2604 & 393 & 15 & 5 \\
\hline 60 & Rubus spp. & 0.00 & 0.00 & 0 & 0 & 0 & 0 & 0.00 & 0.00 & 0 & 0 & 0 & 0 & 0.25 & 0.14 & 2969 & 1829 & 12 & 7 & 990 & 610 & 4 & 2 \\
\hline 60 & $\begin{array}{l}\text { Sambucus } \\
\text { canadensis }\end{array}$ & 0.00 & 0.00 & 0 & 0 & 0 & 0 & 0.00 & 0.00 & 0 & 0 & 0 & 0 & 0.13 & 0.07 & 313 & 180 & 4 & 2 & 104 & 60 & 1 & 1 \\
\hline 60 & Unidentified & 0.00 & 0.00 & 0 & 0 & 0 & 0 & 0.00 & 0.00 & 0 & 0 & 0 & 0 & 0.06 & 0.06 & 313 & 313 & 2 & 2 & 104 & 104 & 1 & 1 \\
\hline
\end{tabular}


Appendix Table 12. Results of mixed model regression testing for significance of fixed effects on the density of Lonicera maackii (modeled as stem counts in each parallel transect). Modeled fixed effects were site, side (north vs. south edge), position (edge or interior location), 2 and 3 way interactions between these variables. P values are based on Type 3 tests of significance. Random effects (the block variable edge-to-interior transect) were omitted from this model due to concerns about over-fitting (see Methods, Statistical Analysis). Post-hoc pairwise comparisons of stem counts between research sites are shown at the bottom. Adjusted $\mathrm{p}$ values were calculated using the Tukey-Kramer method.

\begin{tabular}{cccccc}
\hline \hline & Fixed Effects & & & & \\
\hline Response & Effect & Num & Den & F Value & p \\
& DF & DF & & \\
\hline S. maackii stems & Site & $\mathbf{2}$ & $\mathbf{4 8}$ & $\mathbf{7 . 2 8}$ & $\mathbf{0 . 0 0 1 7}$ \\
& Side & 1 & 48 & 0.62 & 0.4338 \\
& Distance from Edge & 1 & 48 & 0.02 & 0.8997 \\
& Site*Side & 2 & 48 & 0.14 & 0.8696 \\
& Side*Distance from Edge & 1 & 48 & 0.11 & 0.7419 \\
& Site*Distance from Edge & 2 & 48 & 1.68 & 0.1976 \\
& Site*Side*Distance from & 2 & 48 & 1.04 & 0.3613 \\
& Edge & & & & \\
\hline
\end{tabular}

\begin{tabular}{cccrcrrrrr}
\hline \multicolumn{8}{c}{ Between Site Comparisons: Differences of Least Squares Means } \\
\hline Effect & Site & Site & Estimate & $\begin{array}{c}\text { Standard } \\
\text { Error }\end{array}$ & DF & t Value & p & Adj P \\
& & & & & & & & \\
Site & 2 & 1 & -0.062 & 0.4908 & 48 & -0.13 & 0.9001 & 0.9913 \\
Site & $\mathbf{2}$ & $\mathbf{3}$ & $\mathbf{2 . 0 7 8 5}$ & $\mathbf{0 . 5 6 4 4}$ & $\mathbf{4 8}$ & $\mathbf{3 . 6 8}$ & $\mathbf{0 . 0 0 0 6}$ & $\mathbf{0 . 0 0 1 7}$ \\
Site & $\mathbf{1}$ & $\mathbf{3}$ & $\mathbf{2 . 1 4 0 4}$ & $\mathbf{0 . 5 5 8 7}$ & $\mathbf{4 8}$ & $\mathbf{3 . 8 3}$ & $\mathbf{0 . 0 0 0 4}$ & $\mathbf{0 . 0 0 1 1}$ \\
\hline \hline
\end{tabular}


Appendix Table 13. Results of mixed model regression testing for significance of fixed and random effects on total cover of Lonicera japonica. Modeled fixed effects were site, side (north vs. south edge), position (edge or interior location), 2 and 3 way interactions between these variables. Edge-to-interior transect (in table as EITransect) was included as a random effect, nested within each site and side. Post-hoc pairwise comparisons of L. japonica cover between research sites are shown at the bottom. Adjusted $\mathrm{p}$ values were calculated using the Tukey-Kramer method.

\begin{tabular}{|c|c|c|c|c|c|c|c|c|c|c|}
\hline & \multicolumn{5}{|c|}{ Fixed Effects } & \multicolumn{5}{|c|}{ Random Effects } \\
\hline Response & Effect & $\begin{array}{c}\text { Num } \\
\text { DF }\end{array}$ & Den DF & F Value & $\mathrm{p}$ & $\begin{array}{l}\text { Covariance } \\
\text { Parameter }\end{array}$ & Estimate & $\begin{array}{l}\text { Standard } \\
\text { Error }\end{array}$ & $\begin{array}{c}\mathrm{Z} \\
\text { Value }\end{array}$ & $\underset{\text { value }}{\mathrm{p}}$ \\
\hline Total & Site & 2 & 12.5 & 7.1 & 0.0087 & EITransect(Site*side) & 0.006757 & 0.007803 & 0.87 & 0.1933 \\
\hline$L$. & Side & 1 & 12.5 & 0 & 0.9586 & Scale & 0.03266 & 0.007126 & 4.58 & $<.0001$ \\
\hline $\begin{array}{l}\text { japonica } \\
\text { Cover }\end{array}$ & $\begin{array}{c}\text { Distance from } \\
\text { Edge }\end{array}$ & $\mathbf{1}$ & 42 & 6.97 & 0.0116 & & & & & \\
\hline & Site*Side & 2 & 12.5 & 3.64 & 0.0567 & & & & & \\
\hline & $\begin{array}{l}\text { Side*Distance } \\
\text { from Edge }\end{array}$ & 1 & 42 & 0 & 0.9988 & & & & & \\
\hline & $\begin{array}{c}\text { Site*Distance from } \\
\text { Edge }\end{array}$ & 2 & 42 & 0.25 & 0.7763 & & & & & \\
\hline & $\begin{array}{l}\text { Site*Side*Distance } \\
\text { from Edge }\end{array}$ & 2 & 42 & 0.79 & 0.4616 & & & & & \\
\hline \multicolumn{11}{|c|}{ Between Site Comparisons: Differences of Least Squares Means } \\
\hline Effect & Site & Site & Estimate & $\begin{array}{l}\text { Standard } \\
\text { Error }\end{array}$ & $\mathrm{DF}$ & t Value & $\mathrm{p}$ value & Adjustment & Adj P & \\
\hline Site & 2 & 1 & -0.2695 & 0.08151 & 6 & -3.31 & 0.0163 & Tukey & $\mathbf{0 . 0 1 5 3}$ & \\
\hline Site & 2 & 3 & 0.0441 & 0.08151 & 6 & 0.54 & 0.6081 & Tukey & 0.8529 & \\
\hline Site & 1 & 3 & 0.3136 & 0.08151 & 6 & 3.85 & 0.0085 & Tukey & 0.0057 & \\
\hline
\end{tabular}


Appendix Table 14. Mean frequencies, percent cover and IV values for all vine species at varying distance from the forest edge, at each site, and across sites. Bold values indicate the highest mean stem density or IV at each combination of distance and site. In the "Across Sites" column, the highest mean IV and stem density for species occurring at all sites is in bold.

\begin{tabular}{|c|c|c|c|c|c|c|c|c|c|c|c|c|c|c|c|c|c|c|c|c|c|c|c|}
\hline \multirow{3}{*}{$\begin{array}{c}\text { Distance } \\
1\end{array}$} & \multirow{3}{*}{$\begin{array}{l}\text { Species } \\
\text { Campsis } \\
\text { radicans }\end{array}$} & \multicolumn{6}{|c|}{ Site 3: Wet Site } & \multicolumn{6}{|c|}{ "Site 2: Intermediate Site } & \multicolumn{6}{|c|}{ Site 1: Dry Site } & \multicolumn{4}{|c|}{ Across Sites } \\
\hline & & \multicolumn{2}{|c|}{$\begin{array}{c}\text { Mean } \\
\text { Freq. } \pm \text { SE }\end{array}$} & \multicolumn{2}{|c|}{$\begin{array}{c}\text { Mean } \\
\text { Percent } \\
\text { Cover } \pm \text { SE }\end{array}$} & \multicolumn{2}{|c|}{$\begin{array}{c}\text { Mean } \\
\text { IV } \\
\pm \text { SE } \\
\end{array}$} & \multicolumn{2}{|c|}{$\begin{array}{c}\text { Mean } \\
\text { Freq. } \pm \text { SE }\end{array}$} & \multicolumn{2}{|c|}{$\begin{array}{c}\text { Mean } \\
\text { Percent } \\
\text { Cover } \pm \text { SE }\end{array}$} & \multicolumn{2}{|c|}{$\begin{array}{c}\text { Mean } \\
\text { IV } \\
\pm \text { SE } \\
\end{array}$} & \multicolumn{2}{|c|}{$\begin{array}{c}\text { Mean } \\
\text { Freq. } \pm \text { SE }\end{array}$} & \multicolumn{2}{|c|}{$\begin{array}{c}\text { Mean } \\
\text { Percent } \\
\text { Cover } \pm \text { SE }\end{array}$} & \multicolumn{2}{|c|}{$\begin{array}{c}\text { Mean } \\
\text { IV } \\
\pm \text { SE } \\
\end{array}$} & \multicolumn{2}{|c|}{$\begin{array}{l}\text { Mean Percent } \\
\text { Cover } \pm \text { SE }\end{array}$} & \multicolumn{2}{|c|}{$\begin{array}{l}\text { Mean } \\
\mathrm{IV} \pm \mathrm{SE}\end{array}$} \\
\hline & & 0.25 & 0.25 & 4.69 & 4.69 & 20 & 20 & 0.50 & 0.23 & 3.59 & 2.05 & 22 & 15 & 0.19 & 0.19 & 2.81 & 2.81 & 5 & 5 & 3.7 & 0.5 & 16 & 6 \\
\hline 1 & $\begin{array}{l}\text { Euonymus } \\
\text { fortunei }\end{array}$ & 0.06 & 0.06 & 0.16 & 0.16 & 2 & 2 & 0.00 & 0.00 & 0.00 & 0.00 & 0 & 0 & 0.25 & 0.14 & 1.41 & 1.03 & 5 & 3 & 0.5 & 0.4 & 2 & 1 \\
\hline 1 & $\begin{array}{l}\text { Lonicera } \\
\text { japonica }\end{array}$ & 0.44 & 0.26 & 11.41 & 9.81 & 20 & 12 & 0.50 & 0.20 & 8.91 & 6.91 & 15 & 6 & 0.88 & 0.07 & 22.50 & 4.63 & 33 & 5 & 14.3 & 4.2 & 23 & 5 \\
\hline 1 & $\begin{array}{c}\text { Parthenocissus } \\
\text { quinquifolia }\end{array}$ & 0.13 & 0.13 & 0.31 & 0.31 & 2 & 2 & 0.19 & 0.19 & 0.47 & 0.47 & 3 & 3 & 0.44 & 0.19 & 1.09 & 0.47 & 6 & 3 & 0.6 & 0.2 & 4 & 1 \\
\hline 1 & Smilax spp. & 0.06 & 0.06 & 0.16 & 0.16 & 1 & 1 & 0.00 & 0.00 & 0.00 & 0.00 & 0 & 0 & 0.31 & 0.12 & 0.78 & 0.30 & 5 & 2 & 0.3 & 0.2 & 2 & 1 \\
\hline 1 & $\begin{array}{c}\text { Toxicodendron } \\
\text { radicans }\end{array}$ & 0.75 & 0.14 & 15.00 & 10.29 & 53 & 17 & 0.75 & 0.18 & 39.22 & 21.17 & 43 & 15 & 0.88 & 0.07 & 28.13 & 10.52 & 35 & 3 & 27.4 & 7.0 & 44 & 5 \\
\hline 1 & Vitaceae & 0.06 & 0.06 & 0.16 & 0.16 & 1 & 1 & 0.38 & 0.22 & 4.84 & 4.24 & 16 & 9 & 0.50 & 0.18 & 5.00 & 1.71 & 11 & 2 & 3.3 & 1.6 & 9 & 4 \\
\hline 5 & $\begin{array}{l}\text { Campsis } \\
\text { radicans }\end{array}$ & 0.44 & 0.26 & 4.84 & 3.39 & 24 & 14 & 0.25 & 0.18 & 2.19 & 1.98 & 7 & 5 & 0.31 & 0.19 & 1.56 & 1.18 & 7 & $J$ & 2.9 & 1.0 & 13 & 6 \\
\hline 5 & $\begin{array}{l}\text { Euonymus } \\
\text { fortunei }\end{array}$ & 0.00 & 0.00 & 0.00 & 0.00 & 0 & 0 & 0.13 & 0.13 & 2.50 & 2.50 & 4 & 4 & 0.00 & 0.00 & 0.00 & 0.00 & 0 & 0 & 0.8 & 0.8 & 1 & 1 \\
\hline 5 & $\begin{array}{l}\text { Lonicera } \\
\text { japonica }\end{array}$ & 0.13 & 0.13 & 1.25 & 1.25 & 10 & 10 & 0.50 & 0.18 & 5.16 & 2.39 & 12 & 4 & 0.88 & 0.07 & 25.00 & 12.01 & $\mathbf{5 0}$ & 10 & 10.5 & 7.4 & 24 & 13 \\
\hline 5 & $\begin{array}{c}\text { Menispermum } \\
\text { canadensis }\end{array}$ & 0.00 & 0.00 & 0.00 & 0.00 & 0 & 0 & 0.00 & 0.00 & 0.00 & 0.00 & 0 & 0 & 0.06 & 0.06 & 0.94 & 0.94 & 3 & 3 & 0.3 & 0.3 & 1 & 1 \\
\hline 5 & $\begin{array}{c}\text { Parthenocissus } \\
\text { quinquifolia }\end{array}$ & 0.13 & 0.13 & 1.09 & 1.09 & 9 & 9 & 0.44 & 0.21 & 2.34 & 1.74 & 9 & 4 & 0.50 & 0.18 & 1.41 & 0.53 & 9 & 3 & 1.6 & 0.4 & 9 & 0 \\
\hline 5 & Smilax spp. & 0.00 & 0.00 & 0.00 & 0.00 & 0 & 0 & 0.00 & 0.00 & 0.00 & 0.00 & 0 & 0 & 0.19 & 0.12 & 2.19 & 1.98 & 5 & T & 0.7 & 0.7 & 2 & 2 \\
\hline 5 & $\begin{array}{c}\text { Toxicodendron } \\
\text { radicans }\end{array}$ & 0.56 & 0.21 & 7.97 & 6.54 & 31 & 13 & 1.00 & 0.00 & 61.25 & 8.69 & 61 & 4 & 0.81 & 0.12 & 6.09 & 1.88 & 23 & 2 & 25.1 & 18.1 & 38 & 11 \\
\hline 5 & Vitaceae & 0.06 & 0.06 & 0.16 & 0.16 & 25 & 25 & 0.31 & 0.06 & 0.78 & 0.16 & 7 & 2 & 0.19 & 0.12 & 0.47 & 0.30 & 3 & 2 & 0.5 & 0.2 & 12 & 7 \\
\hline
\end{tabular}




\begin{tabular}{|c|c|c|c|c|c|c|c|c|c|c|c|c|c|c|c|c|c|c|c|c|c|c|c|}
\hline \multirow{3}{*}{$\begin{array}{c}\text { Distance } \\
10\end{array}$} & \multirow{3}{*}{$\begin{array}{l}\text { Species } \\
\text { Campsis } \\
\text { radicans }\end{array}$} & \multicolumn{6}{|c|}{ Site 3: Wet Site } & \multicolumn{6}{|c|}{ "Site 2: Intermediate Site } & \multicolumn{6}{|c|}{ Site 1: Dry Site } & \multicolumn{4}{|c|}{ Across Sites } \\
\hline & & \multicolumn{2}{|c|}{$\begin{array}{c}\text { Mean } \\
\text { Freq. } \pm \mathrm{SE}\end{array}$} & \multicolumn{2}{|c|}{$\begin{array}{c}\text { Mean } \\
\text { Percent } \\
\text { Cover } \pm \text { SE }\end{array}$} & \multicolumn{2}{|c|}{$\begin{array}{c}\text { Mean } \\
\text { IV } \\
\pm \text { SE }\end{array}$} & \multicolumn{2}{|c|}{$\begin{array}{c}\text { Mean } \\
\text { Freq. } \pm \text { SE }\end{array}$} & \multicolumn{2}{|c|}{$\begin{array}{c}\text { Mean } \\
\text { Percent } \\
\text { Cover } \pm \text { SE }\end{array}$} & \multicolumn{2}{|c|}{$\begin{array}{c}\text { Mean } \\
\text { IV } \\
\pm \text { SE }\end{array}$} & \multicolumn{2}{|c|}{$\begin{array}{c}\text { Mean } \\
\text { Freq. } \pm \text { SE }\end{array}$} & \multicolumn{2}{|c|}{$\begin{array}{c}\text { Mean } \\
\text { Percent } \\
\text { Cover } \pm \text { SE }\end{array}$} & \multicolumn{2}{|c|}{$\begin{array}{c}\text { Mean } \\
\text { IV } \\
\pm \text { SE }\end{array}$} & \multicolumn{2}{|c|}{$\begin{array}{l}\text { Mean Percent } \\
\text { Cover } \pm \text { SE }\end{array}$} & \multicolumn{2}{|c|}{$\begin{array}{c}\text { Mean } \\
\mathrm{IV} \pm \mathrm{SE}\end{array}$} \\
\hline & & 0.25 & 0.18 & 1.41 & 1.21 & 13 & 8 & 0.31 & 0.16 & 0.78 & 0.39 & 9 & 4 & 0.00 & 0.00 & 0.00 & 0.00 & 0 & 0 & 0.7 & 0.4 & 7 & 4 \\
\hline 10 & $\begin{array}{l}\text { Euonymus } \\
\text { fortunei }\end{array}$ & 0.00 & 0.00 & 0.00 & 0.00 & 0 & 0 & 0.00 & 0.00 & 0.00 & 0.00 & 0 & 0 & 0.06 & 0.06 & 0.16 & 0.16 & 1 & 1 & 0.1 & 0.1 & 0 & 0 \\
\hline 10 & $\begin{array}{l}\text { Lonicera } \\
\text { japonica }\end{array}$ & 0.19 & 0.12 & 1.41 & 1.03 & 7 & 4 & 0.31 & 0.16 & 1.56 & 1.16 & 7 & 3 & 0.75 & 0.25 & 26.56 & 10.84 & 37 & 12 & 9.8 & 8.4 & 17 & 10 \\
\hline 10 & $\begin{array}{c}\text { Menispermum } \\
\text { canadensis }\end{array}$ & 0.00 & 0.00 & 0.00 & 0.00 & 0 & 0 & 0.13 & 0.13 & 1.09 & 1.09 & 2 & 2 & 0.13 & 0.07 & 0.47 & 0.30 & 2 & 1 & 0.5 & 0.3 & 2 & 1 \\
\hline 10 & $\begin{array}{c}\text { Parthenocissus } \\
\text { quinquifolia }\end{array}$ & 0.25 & 0.14 & 0.78 & 0.47 & 7 & 4 & 0.31 & 0.24 & 8.28 & 8.07 & 11 & 8 & 0.50 & 0.23 & 2.03 & 1.26 & 10 & 5 & 3.7 & 2.3 & 9 & 1 \\
\hline 10 & Smilax spp. & 0.00 & 0.00 & 0.00 & 0.00 & 0 & 0 & 0.06 & 0.06 & 0.16 & 0.16 & 2 & 2 & 0.25 & 0.18 & 0.63 & 0.44 & 4 & 3 & 0.3 & 0.2 & 2 & 1 \\
\hline 10 & $\begin{array}{c}\text { Toxicodendron } \\
\text { radicans }\end{array}$ & 0.63 & 0.16 & 8.75 & 4.60 & 69 & 12 & 0.94 & 0.06 & 39.69 & 11.14 & 67 & 11 & 0.69 & 0.19 & 8.59 & 4.66 & 42 & 20 & 19.0 & 10.3 & 59 & 9 \\
\hline 10 & Vitaceae & 0.13 & 0.07 & 0.47 & 0.30 & 4 & 2 & 0.13 & 0.07 & 0.31 & 0.18 & 2 & 1 & 0.19 & 0.12 & 0.47 & 0.30 & 3 & 2 & 0.4 & 0.1 & 3 & 0 \\
\hline 30 & $\begin{array}{l}\text { Campsis } \\
\text { radicans }\end{array}$ & 0.31 & 0.19 & 3.91 & 3.13 & 30 & 24 & 0.00 & 0.00 & 0.00 & 0.00 & 0 & 0 & 0.06 & 0.06 & 0.16 & 0.16 & 2 & 2 & 1.4 & 1.3 & 11 & 10 \\
\hline 30 & $\begin{array}{l}\text { Euonymus } \\
\text { fortunei }\end{array}$ & 0.00 & 0.00 & 0.00 & 0.00 & 0 & 0 & 0.00 & 0.00 & 0.00 & 0.00 & 0 & 0 & 0.25 & 0.25 & 16.25 & 16.25 & 12 & 12 & 5.4 & 5.4 & 4 & 4 \\
\hline 30 & $\begin{array}{l}\text { Lonicera } \\
\text { japonica }\end{array}$ & 0.19 & 0.12 & 2.66 & 2.45 & 11 & 9 & 0.25 & 0.25 & 11.72 & 11.72 & 8 & 8 & 0.81 & 0.19 & 12.03 & 7.16 & 34 & 11 & 8.8 & 3.1 & 18 & 8 \\
\hline 30 & $\begin{array}{c}\text { Menispermum } \\
\text { canadensis }\end{array}$ & 0.00 & 0.00 & 0.00 & 0.00 & 0 & 0 & 0.00 & 0.00 & 0.00 & 0.00 & 0 & 0 & 0.19 & 0.19 & 0.47 & 0.47 & 6 & 6 & 0.2 & 0.2 & 2 & 2 \\
\hline 30 & $\begin{array}{c}\text { Parthenocissus } \\
\text { quinquifolia }\end{array}$ & 0.06 & 0.06 & 0.16 & 0.16 & 3 & 3 & 0.44 & 0.26 & 10.16 & 6.45 & 13 & 7 & 0.19 & 0.12 & 0.47 & 0.30 & 5 & 4 & 3.6 & 3.3 & 7 & 3 \\
\hline 30 & Smilax spp. & 0.00 & 0.00 & 0.00 & 0.00 & 0 & 0 & 0.06 & 0.06 & 0.16 & 0.16 & 2 & 2 & 0.31 & 0.06 & 1.56 & 0.74 & 12 & 4 & 0.6 & 0.5 & 5 & 4 \\
\hline 30 & $\begin{array}{c}\text { Toxicodendron } \\
\text { radicans }\end{array}$ & 0.50 & 0.20 & 25.63 & 18.93 & 55 & 21 & 0.75 & 0.25 & 47.97 & 16.23 & 46 & 18 & 0.44 & 0.21 & 1.41 & 0.82 & 14 & 6 & 25.0 & 13.4 & 38 & 13 \\
\hline 30 & Vitaceae & 0.06 & 0.06 & 0.16 & 0.16 & 2 & 2 & 0.31 & 0.16 & 1.56 & 1.16 & 7 & 3 & 0.31 & 0.12 & 4.53 & 3.91 & 16 & 9 & 2.1 & 1.3 & 8 & 4 \\
\hline
\end{tabular}




\begin{tabular}{|c|c|c|c|c|c|c|c|c|c|c|c|c|c|c|c|c|c|c|c|c|c|c|c|}
\hline \multirow[b]{2}{*}{ Distance } & \multirow[b]{2}{*}{ Species } & \multicolumn{6}{|c|}{ Site 3: Wet Site } & \multicolumn{6}{|c|}{ "Site 2: Intermediate Site } & \multicolumn{6}{|c|}{ Site 1: Dry Site } & \multicolumn{4}{|c|}{ Across Sites } \\
\hline & & \multicolumn{2}{|c|}{$\begin{array}{c}\text { Mean } \\
\text { Freq. } \pm \text { SE }\end{array}$} & \multicolumn{2}{|c|}{$\begin{array}{c}\text { Mean } \\
\text { Percent } \\
\text { Cover } \pm \mathrm{SE}\end{array}$} & \multicolumn{2}{|c|}{$\begin{array}{c}\text { Mean } \\
\text { IV } \\
\pm \text { SE }\end{array}$} & \multicolumn{2}{|c|}{$\begin{array}{c}\text { Mean } \\
\text { Freq. } \pm \text { SE }\end{array}$} & \multicolumn{2}{|c|}{$\begin{array}{c}\text { Mean } \\
\text { Percent } \\
\text { Cover } \pm \text { SE }\end{array}$} & \multicolumn{2}{|c|}{$\begin{array}{c}\text { Mean } \\
\text { IV } \\
\pm \text { SE } \\
\end{array}$} & \multicolumn{2}{|c|}{$\begin{array}{c}\text { Mean } \\
\text { Freq. } \pm \text { SE }\end{array}$} & \multicolumn{2}{|c|}{$\begin{array}{c}\text { Mean } \\
\text { Percent } \\
\text { Cover } \pm \text { SE }\end{array}$} & \multicolumn{2}{|c|}{$\begin{array}{c}\text { Mean } \\
\text { IV } \\
\pm \text { SE }\end{array}$} & \multicolumn{2}{|c|}{$\begin{array}{c}\text { Mean Percent } \\
\text { Cover } \pm \mathrm{SE}\end{array}$} & \multicolumn{2}{|c|}{$\begin{array}{c}\text { Mean } \\
\text { IV } \pm \text { SE }\end{array}$} \\
\hline 60 & $\begin{array}{l}\text { Campsis } \\
\text { radicans }\end{array}$ & 0.13 & 0.13 & 1.88 & 1.88 & 25 & 25 & 0.00 & 0.00 & 0.00 & 0.00 & 0 & 0 & 0.19 & 0.12 & 0.47 & 0.30 & 6 & 4 & 0.8 & 0.6 & 10 & 8 \\
\hline 60 & $\begin{array}{l}\text { Lonicera } \\
\text { japonica }\end{array}$ & 0.19 & 0.19 & 0.47 & 0.47 & 4 & 4 & 0.00 & 0.00 & 0.00 & 0.00 & 0 & 0 & 0.63 & 0.22 & 11.88 & 6.14 & 35 & 10 & 4.1 & 3.9 & 13 & 11 \\
\hline 60 & $\begin{array}{c}\text { Menispermum } \\
\text { canadensis }\end{array}$ & 0.00 & 0.00 & 0.00 & 0.00 & 0 & 0 & 0.00 & 0.00 & 0.00 & 0.00 & 0 & 0 & 0.06 & 0.06 & 0.16 & 0.16 & 1 & 1 & 0.1 & 0.1 & 0 & 0 \\
\hline 60 & $\begin{array}{c}\text { Parthenocissus } \\
\text { quinquifolia }\end{array}$ & 0.25 & 0.18 & 0.63 & 0.44 & 7 & 4 & 0.19 & 0.12 & 1.25 & 0.88 & 11 & 6 & 0.69 & 0.24 & 1.72 & 0.59 & 19 & 9 & 1.2 & 0.3 & 12 & 4 \\
\hline 60 & Smilax spp. & 0.00 & 0.00 & 0.00 & 0.00 & 0 & 0 & 0.00 & 0.00 & 0.00 & 0.00 & 0 & 0 & 0.31 & 0.12 & 4.69 & 4.07 & 16 & 6 & 1.6 & 1.6 & 5 & 5 \\
\hline 60 & $\begin{array}{c}\text { Toxicodendron } \\
\text { radicans }\end{array}$ & 0.50 & 0.29 & 22.34 & 13.74 & 37 & 22 & 0.69 & 0.06 & 16.25 & 10.02 & 71 & 7 & 0.44 & 0.12 & 2.81 & 1.78 & 16 & 4 & 13.8 & 5.8 & 41 & 16 \\
\hline 60 & Vitaceae & 0.06 & 0.06 & 0.16 & 0.16 & 2 & 2 & 0.19 & 0.12 & 0.47 & 0.30 & 18 & 12 & 0.19 & 0.06 & 0.47 & 0.16 & 6 & 3 & 0.4 & 0.1 & 9 & 5 \\
\hline
\end{tabular}


Appendix Table 15. Plant-level data for all individuals of Lonicera maackii surveyed. Days flooded refers to the transect, not the individual plant. Rank elevation refer to the relative elevation of each plant at the transect level. Individuals ranked as having rank elevations of 100 had absolute elevations equal to or greater than the highest elevation recorded in the ground survey of transect elevations. Individuals ranked as having rank elevation of 0 had absolute elevations less than or equal to the lowest elevation recorded in the ground survey of transect elevations. Transect ID is in the format: (site)-(edge-tointerior transect ID)-(distance from edge).

\begin{tabular}{ccccc}
\hline \hline $\begin{array}{c}\text { Transect } \\
\text { ID }\end{array}$ & $\begin{array}{c}\text { Number } \\
\text { of } \\
\text { Stems }\end{array}$ & $\begin{array}{c}\text { Stem } \\
\text { Height }\end{array}$ & $\begin{array}{c}\text { Rank } \\
\text { Elevation }\end{array}$ & $\begin{array}{c}\text { Days } \\
\text { Flooded } \\
\text { (Transect } \\
\text { Average) }\end{array}$ \\
\hline 3-N1-30m & 3 & 2 & 100 & 42.5 \\
3-N2-1m & 1 & 0.25 & 99.3 & 40.9 \\
1-N2-30m & 9 & 2.5 & 49.7 & 28.1 \\
1-N2-30m & 3 & 2 & 72.4 & 28.1 \\
1-N2-30m & 5 & 2.5 & 76.9 & 28.1 \\
2-S2-10m & 3 & 0.5 & 100 & 21.4 \\
2-S1-30m & 8 & 2 & 95.6 & 17.3 \\
2-S1-30m & 1 & 0.25 & 58.9 & 17.3 \\
2-S1-10m & 3 & 2 & 98.8 & 15.3 \\
2-S1-10m & 3 & 2.5 & 91.4 & 15.3 \\
2-N2-5m & 3 & 3 & 56.4 & 10.85 \\
2-N2-5m & 3 & 3 & 61.5 & 10.85 \\
2-N2-5m & 2 & 2 & 44.8 & 10.85 \\
2-N2-5m & 4 & 4 & 87.1 & 10.85 \\
2-N2-5m & 2 & 2 & 89.7 & 10.85 \\
2-N2-5m & 3 & 1 & 91.4 & 10.85 \\
2-N2-5m & 2 & 1 & 89.7 & 10.85 \\
2-N2-5m & 2 & 0.5 & 83.8 & 10.85 \\
2-N2-5m & 2 & 1 & 48.7 & 10.85 \\
2-N2-5m & 5 & 2 & 92.6 & 10.85 \\
2-N1-10m & 1 & 0.25 & 96.3 & 10.65 \\
2-N1-10m & 3 & 2 & 100 & 10.65 \\
2-N1-10m & 2 & 2 & 95.9 & 10.65 \\
2-N1-10m & 2 & 2 & 96.3 & 10.65 \\
2-N1-10m & 3 & 2 & 100 & 10.65 \\
2-N1-10m & 4 & 2 & 97.2 & 10.65 \\
2-N1-10m & 5 & 2 & 100 & 10.65 \\
2-N1-10m & 3 & 0.25 & 96.9 & 10.65 \\
2-N1-10m & 1 & 0.5 & 96.6 & 10.65 \\
2-N1-10m & 3 & 1 & 95.3 & 10.65 \\
1-N2-60m & 2 & 0.5 & 69 & 10.25 \\
3-S1-30m & 3 & 0.5 & 89.7 & 8.7 \\
\hline \hline & & & & \\
\hline
\end{tabular}




\begin{tabular}{|c|c|c|c|c|}
\hline $\begin{array}{c}\text { Transect } \\
\text { ID }\end{array}$ & $\begin{array}{c}\text { Number } \\
\text { of } \\
\text { Stems }\end{array}$ & $\begin{array}{c}\text { Stem } \\
\text { Height }\end{array}$ & $\begin{array}{c}\text { Rank } \\
\text { Elevation }\end{array}$ & $\begin{array}{c}\text { Days } \\
\text { Flooded } \\
\text { (Transect } \\
\text { Average) }\end{array}$ \\
\hline 3-S1-30m & 1 & 0.25 & 92.1 & 8.7 \\
\hline $2-\mathrm{S} 1-5 \mathrm{~m}$ & 2 & 0.5 & 33.3 & 8.2 \\
\hline $2-\mathrm{S} 1-5 \mathrm{~m}$ & 5 & 1 & 84.9 & 8.2 \\
\hline $2-\mathrm{S} 1-5 \mathrm{~m}$ & 2 & 1 & 79.4 & 8.2 \\
\hline $2-\mathrm{S} 1-5 \mathrm{~m}$ & 3 & 1 & 96.2 & 8.2 \\
\hline $2-\mathrm{S} 2-5 \mathrm{~m}$ & 6 & 2 & 100 & 5.4 \\
\hline $2-\mathrm{S} 2-5 \mathrm{~m}$ & 5 & 1 & 73.6 & 5.4 \\
\hline $2-\mathrm{S} 2-5 \mathrm{~m}$ & 4 & 1 & 100 & 5.4 \\
\hline $2-\mathrm{S} 2-5 \mathrm{~m}$ & 7 & 2 & 98.3 & 5.4 \\
\hline $2-5 \mathrm{~m}$ & 9 & 2 & 0 & 4.05 \\
\hline $1-\mathrm{S} 2-5 \mathrm{~m}$ & 2 & 2 & 33.3 & 4.05 \\
\hline $3-\mathrm{S} 1-1 \mathrm{~m}$ & 2 & 2 & 100 & 2.6 \\
\hline $3-\mathrm{S} 1-1 \mathrm{~m}$ & 2 & 2 & 100 & 2.6 \\
\hline $3-\mathrm{S} 1-1 \mathrm{~m}$ & 1 & 0.25 & 100 & 2.6 \\
\hline $3-S 1-60 m$ & 11 & 2 & 90.1 & 2.2 \\
\hline $3-S 1-60 m$ & 3 & 2.5 & 89.4 & 2.2 \\
\hline $1-\mathrm{S} 2-60 \mathrm{~m}$ & 1 & 0.25 & 94.8 & 1.2 \\
\hline $1-\mathrm{S} 2-60 \mathrm{~m}$ & 2 & 1 & 88.2 & 1.2 \\
\hline $1-\mathrm{S} 2-60 \mathrm{~m}$ & 2 & 1 & 33.3 & 1.2 \\
\hline $1-\mathrm{S} 1-60 \mathrm{~m}$ & 3 & 1 & 32.3 & 0.925 \\
\hline $1-\mathrm{S} 1-60 \mathrm{~m}$ & 7 & 2 & 4.1 & 0.925 \\
\hline $1-\mathrm{N} 2-10 \mathrm{~m}$ & 3 & 0.5 & 100 & 0.8 \\
\hline $1-\mathrm{S} 2-30 \mathrm{~m}$ & 7 & 2.5 & 89.1 & 0.575 \\
\hline $1-\mathrm{S} 2-30 \mathrm{~m}$ & 1 & 1 & 76 & 0.575 \\
\hline $1-\mathrm{S} 2-30 \mathrm{~m}$ & 2 & 2.5 & 7.6 & 0.575 \\
\hline $1-\mathrm{S} 2-30 \mathrm{~m}$ & 7 & 2 & 38.4 & 0.575 \\
\hline $1-\mathrm{S} 2-30 \mathrm{~m}$ & 3 & 2 & 61.5 & 0.575 \\
\hline $1-\mathrm{S} 2-30 \mathrm{~m}$ & 4 & 2 & 61.5 & 0.575 \\
\hline $1-\mathrm{S} 2-30 \mathrm{~m}$ & 1 & 0.25 & 85.8 & 0.575 \\
\hline $1-\mathrm{S} 2-30 \mathrm{~m}$ & . & . & 85.8 & 0.575 \\
\hline $1-\mathrm{S} 2-30 \mathrm{~m}$ & . & . & 85.8 & 0.575 \\
\hline $1-\mathrm{S} 2-30 \mathrm{~m}$ & 3 & 2 & 87.1 & 0.575 \\
\hline $2-\mathrm{N} 1-5 \mathrm{~m}$ & 3 & 2 & 98.9 & 0.4 \\
\hline $1-\mathrm{S} 1-1 \mathrm{~m}$ & 2 & 1 & 41 & 0 \\
\hline $1-\mathrm{S} 1-1 \mathrm{~m}$ & 3 & 1 & 72.6 & 0 \\
\hline $1-\mathrm{S} 1-1 \mathrm{~m}$ & 3 & 1 & 85.4 & 0 \\
\hline $1-\mathrm{S} 1-1 \mathrm{~m}$ & 5 & 1 & 25.6 & 0 \\
\hline $1-\mathrm{S} 1-1 \mathrm{~m}$ & 2 & 0.5 & 13.6 & 0 \\
\hline $1-\mathrm{S} 1-10 \mathrm{~m}$ & 1 & 1 & 33.3 & 0 \\
\hline $1-\mathrm{S} 1-10 \mathrm{~m}$ & 5 & 1 & 56.4 & 0 \\
\hline $1-\mathrm{S} 1-10 \mathrm{~m}$ & 1 & 0.25 & 97.4 & 0 \\
\hline $1-\mathrm{S} 1-30 \mathrm{~m}$ & 1 & 0.25 & 69.2 & 0 \\
\hline
\end{tabular}




\begin{tabular}{ccccc}
\hline $\begin{array}{c}\text { Transect } \\
\text { ID }\end{array}$ & $\begin{array}{c}\text { Number } \\
\text { of } \\
\text { Stems }\end{array}$ & $\begin{array}{c}\text { Stem } \\
\text { Height }\end{array}$ & $\begin{array}{c}\text { Rank } \\
\text { Elevation }\end{array}$ & $\begin{array}{c}\text { Days } \\
\text { Flooded } \\
\text { (Transect } \\
\text { Average) }\end{array}$ \\
\hline $1-\mathrm{N} 1-1 \mathrm{~m}$ & 1 & 0.25 & 18.6 &. \\
$1-\mathrm{N} 1-1 \mathrm{~m}$ & 1 & 0.25 & 31.4 &. \\
$1-\mathrm{N} 1-1 \mathrm{~m}$ & 1 & 0.25 & 48.7 &. \\
$1-\mathrm{N} 1-1 \mathrm{~m}$ & 1 & 0.25 & 14.1 &. \\
$1-\mathrm{N} 1-1 \mathrm{~m}$ & 1 & 0.25 & 14.1 &. \\
$1-\mathrm{N} 1-1 \mathrm{~m}$ & 1 & 0.25 & 40.3 &. \\
$1-\mathrm{N} 1-1 \mathrm{~m}$ & 1 & 0.25 & 40.3 &. \\
$1-\mathrm{N} 1-1 \mathrm{~m}$ & 1 & 2 & 47 &. \\
$1-\mathrm{N} 1-5 \mathrm{~m}$ & 1 & 0.5 & 97.9 &. \\
$1-\mathrm{N} 1-5 \mathrm{~m}$ & 2 & 2.5 & 100 &. \\
$1-\mathrm{N} 1-60 \mathrm{~m}$ & 2 & 0.5 & 100 &. \\
$1-\mathrm{N} 1-60 \mathrm{~m}$ & 2 & 2 & 97.4 &. \\
\hline \hline
\end{tabular}


Appendix Table 16. Wetland indicator status code, and species designations for species encountered in this study.

\begin{tabular}{|c|c|c|c|}
\hline Indicator Code & Indicator Status & Designation & Comment \\
\hline $\mathrm{OBL}$ & Obligate Wetland & Hydrophyte & $\begin{array}{c}\text { Almost always occur } \\
\text { in wetlands }\end{array}$ \\
\hline FACW & Facultative Wetland & Hydrophyte & $\begin{array}{c}\text { Usually occur in } \\
\text { wetlands, but may } \\
\text { occur in non-wetlands }\end{array}$ \\
\hline FAC & Facultative & Hydrophyte & $\begin{array}{c}\text { Occur in wetlands and } \\
\text { non-wetlands }\end{array}$ \\
\hline FACU & Facultative Upland & Non-hydrophyte & $\begin{array}{l}\text { Usually occur in non- } \\
\text { wetlands, but may } \\
\text { occur in wetlands }\end{array}$ \\
\hline UPL & Obligate Upland & Non-hydrophyte & $\begin{array}{c}\text { Almost never occur in } \\
\text { wetlands }\end{array}$ \\
\hline $\mathrm{NE}$ & Not Evaluated & & \\
\hline
\end{tabular}

\begin{tabular}{ccc}
\hline Species & Form & WIS \\
\hline Aralia spinosa & SHRUB & FAC \\
Cephalanthus occidentalis & SHRUB & OBL \\
Cornus foemina & SHRUB & FACW \\
Euonymus americanus & SHRUB & FAC \\
Lindera benzoin & SHRUB & FAC \\
Lonicera maackii & SHRUB & NE \\
Symphoricarpos orbiculatus & SHRUB & FACU \\
Sambucus canadensis & SHRUB & FAC \\
Acer negundo & TREE & FAC \\
Acer rubrum & TREE & FAC \\
Acer saccharinum & TREE & FACW \\
Asimina triloba & TREE & FAC \\
Celtis laevigata & TREE & FACW \\
Cornus florida & TREE & FACU \\
Diospyros virginiana & TREE & FAC \\
Fagus grandifolia & TREE & TREE \\
Fraxinus pennsylvanica & TREE & FACW \\
Juniperus virginiana & TREE & FACU \\
\hline \hline
\end{tabular}




\begin{tabular}{ccc} 
Liquidambar styraciflua & TREE & FAC \\
Liriodendron tulipifera & TREE & FACU \\
Nyssa sylvatica & TREE & FAC \\
Platanus occidentalis & TREE & FACW \\
Populus deltoides & TREE & FAC \\
Quercus bicolor & TREE & FACW \\
Quercus lyrata & TREE & OBL \\
Quercus michauxii & TREE & FACW \\
Quercus palustris & TREE & FACW \\
Salix nigra & TREE & OBL \\
Ulmus americana & TREE & FACW \\
Ulmus rubra & TREE & FAC \\
Campsis radicans & VINE & FAC \\
Euonymus fortunei & VINE & NE \\
Lonicera japonica & VINE & FAC \\
Menispermum canadense & VINE & FACU \\
Parthenocissus quinquifolia & VINE & FACU \\
Toxicodendron radicans & VINE & FAC \\
\hline
\end{tabular}




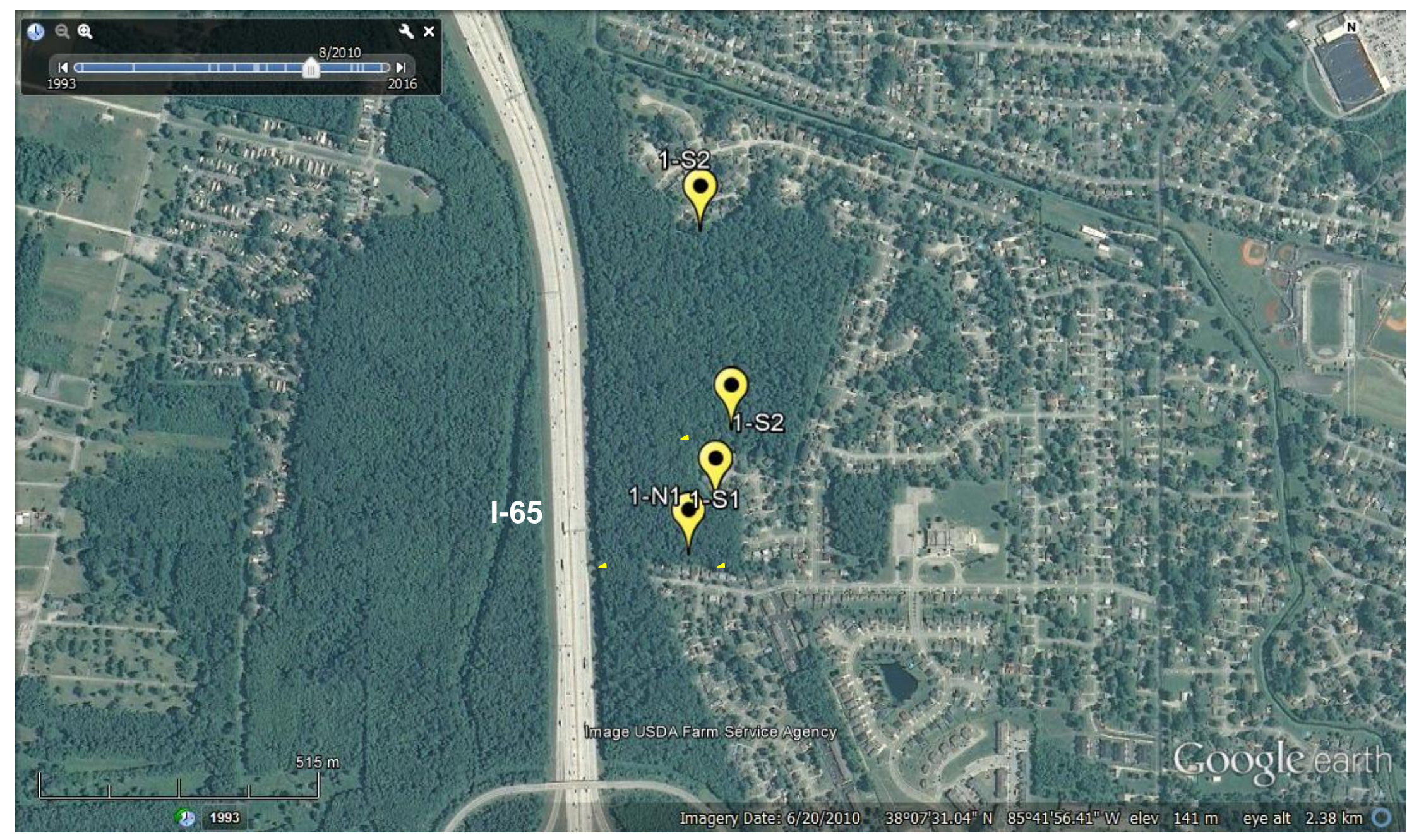

Appendix Figure 1. Aerial imagery showing Site 1 (dry site) in Jefferson County, Kentucky (Louisville Metro Area). Each tagged marker represents the location of an edge-to-interior transect. 


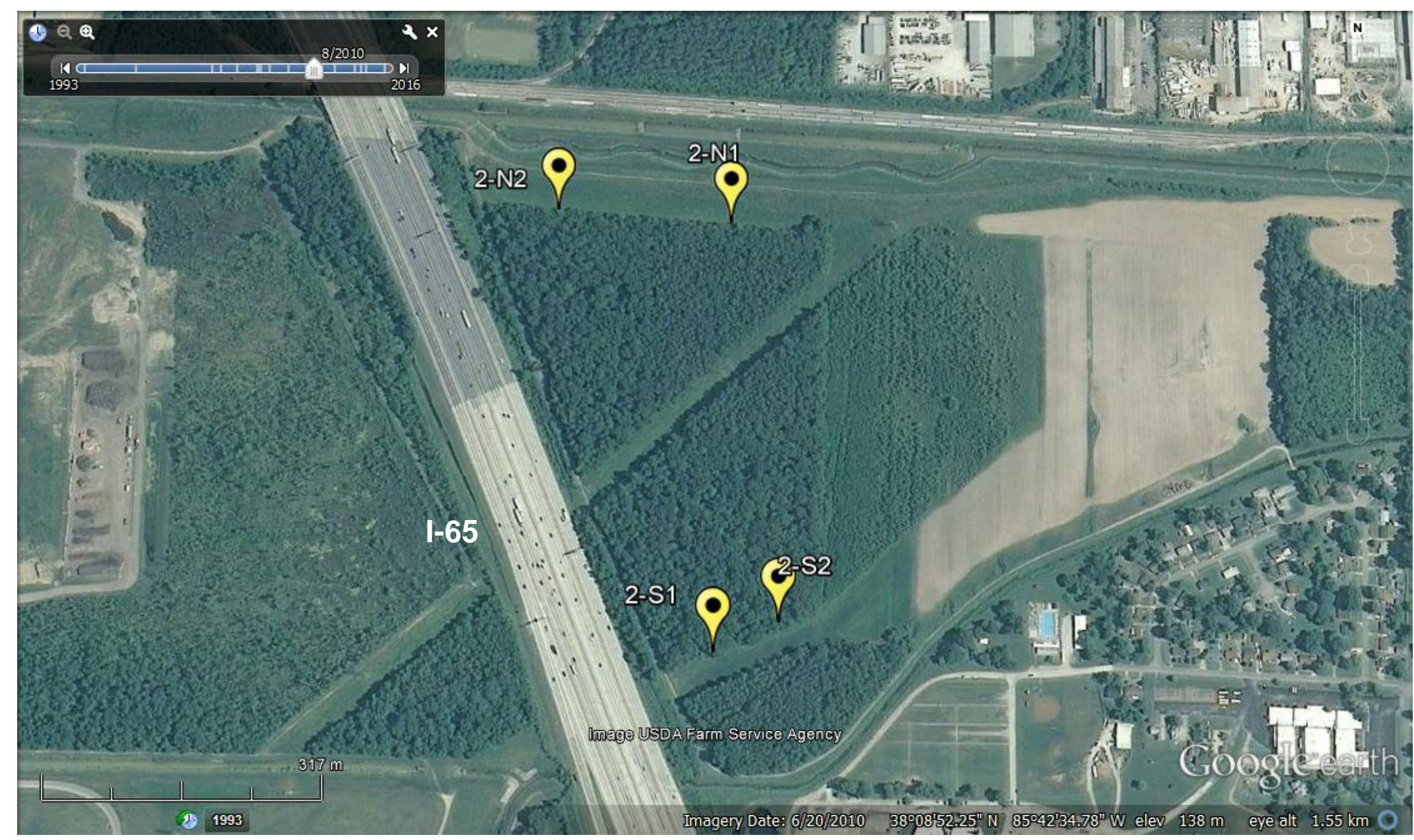

Appendix Figure 2. Aerial imagery showing Site 2 (intermediate site) in Jefferson County, Kentucky (Louisville Metro Area). Each tagged marker represents the location of an edge-to-interior transect. 


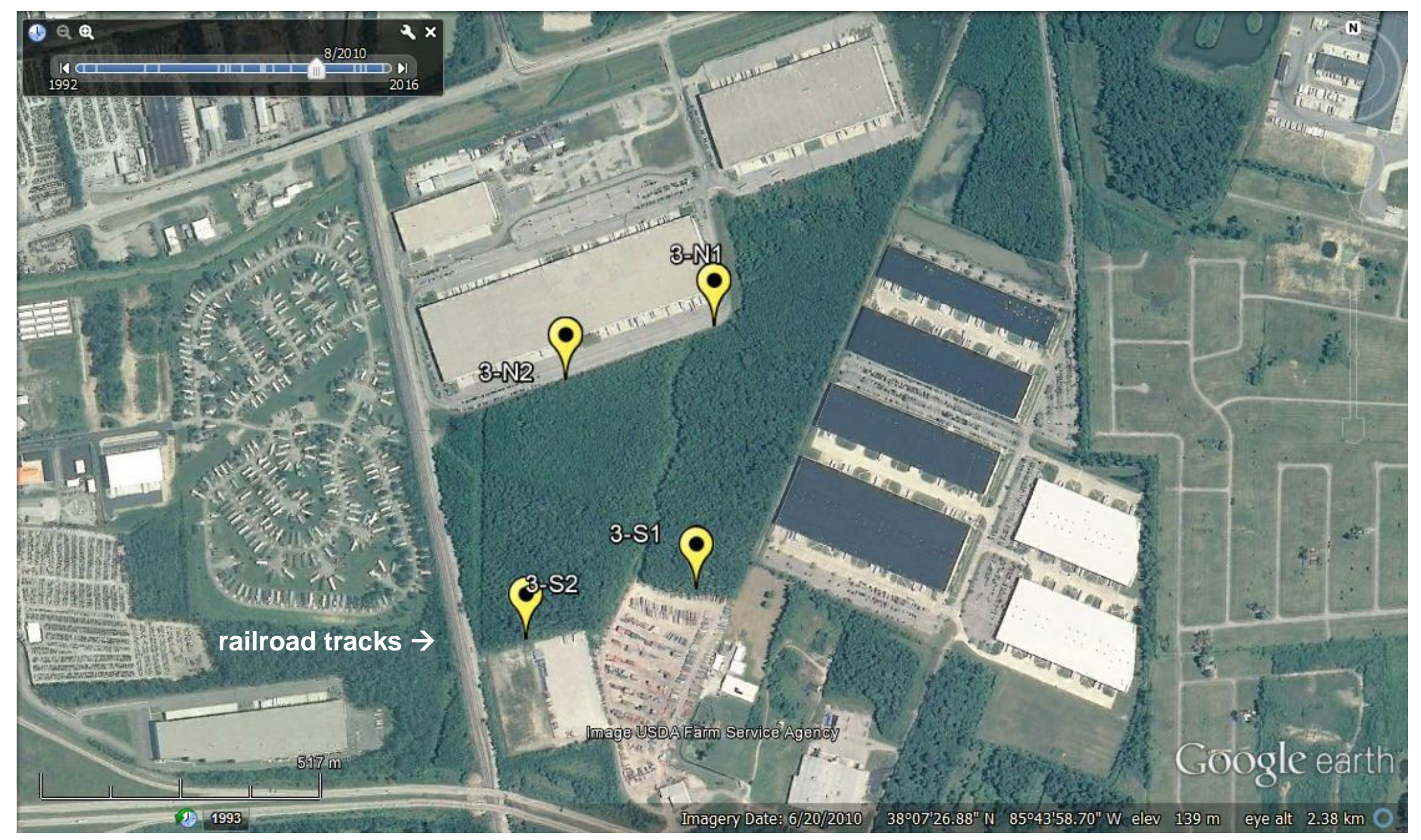

Appendix Figure 3. Aerial imagery showing Site 3 (wet site) in Jefferson County, Kentucky (Louisville Metro Area). Each tagged marker represents the location of an edge-to-interior transect. 


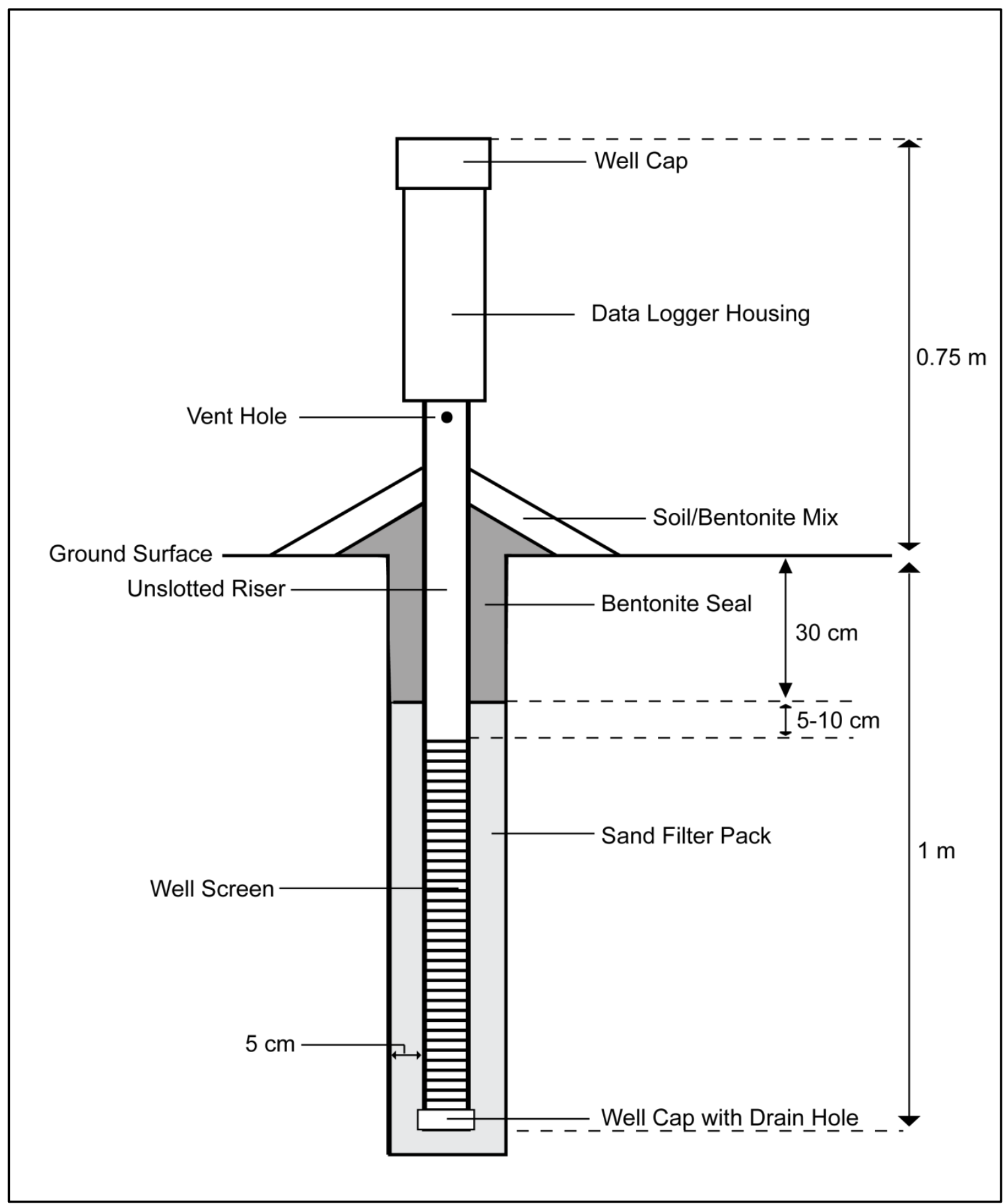

Appendix Figure 4. Diagram depicting general construction of the groundwater monitoring wells used in this study. In this study, wells extended $1 \mathrm{~m}$ below the ground surface, with the riser and PVC housing for a data logger extending $0.75 \mathrm{~m}$ above the ground surface. Image adapted from Sprecher (2008). Image is not to scale. 


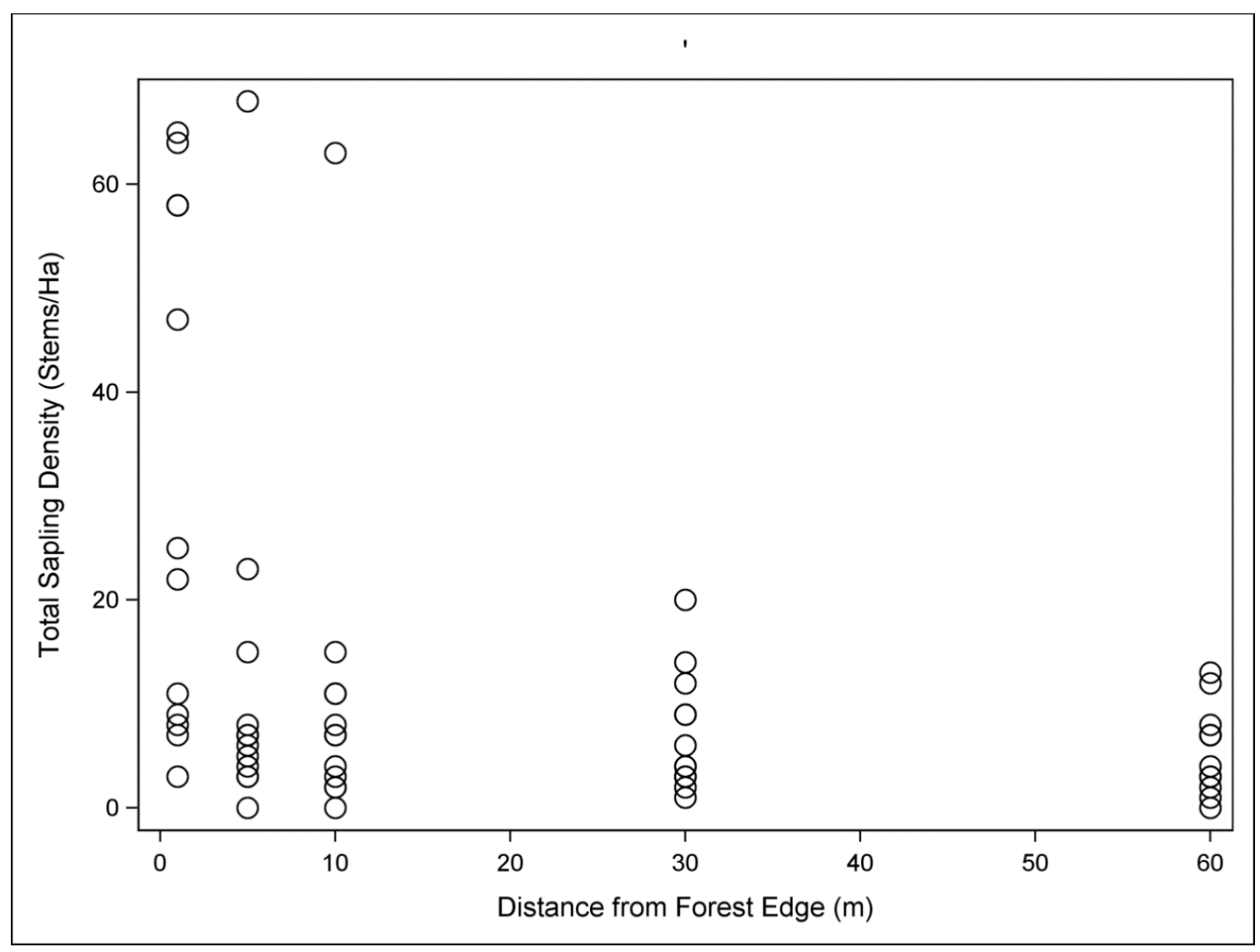

Appendix Figure 5. Total sapling stem density (stems/Ha) vs. distance from forest edge. Each data point represents the mean vine cover in a transect at 1, 5, 10, 30 or 60 meters from the forest edge. Data from all 60 transects (20 per site) is included. 


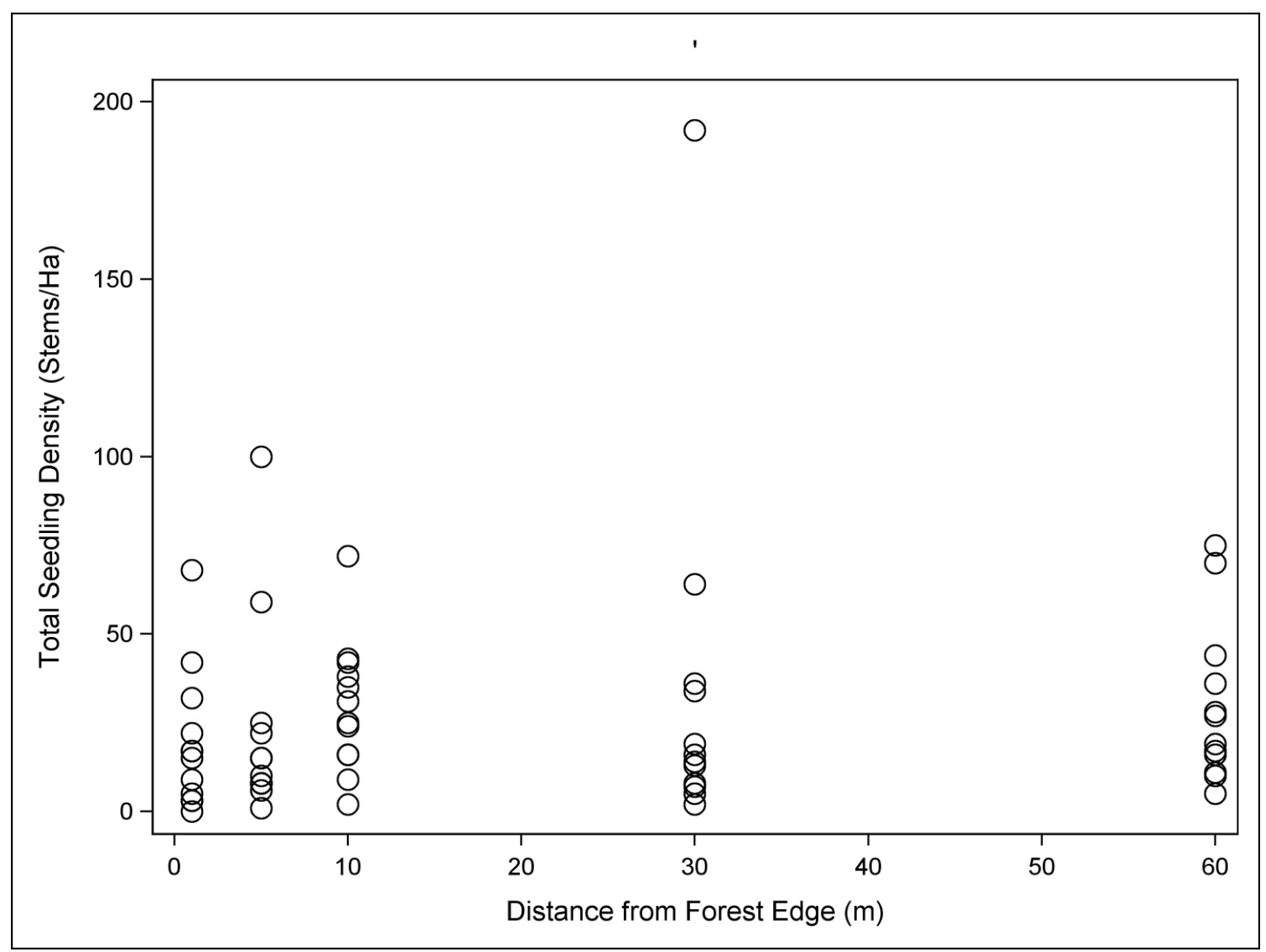

Appendix Figure 6. Total seedling stem density (stems/Ha) vs. distance from forest edge. Each data point represents the seedling density in a transect at 1, 5, 10, 30 or 60 meters from the forest edge. Data from all 60 transects (20 per site) is included. 


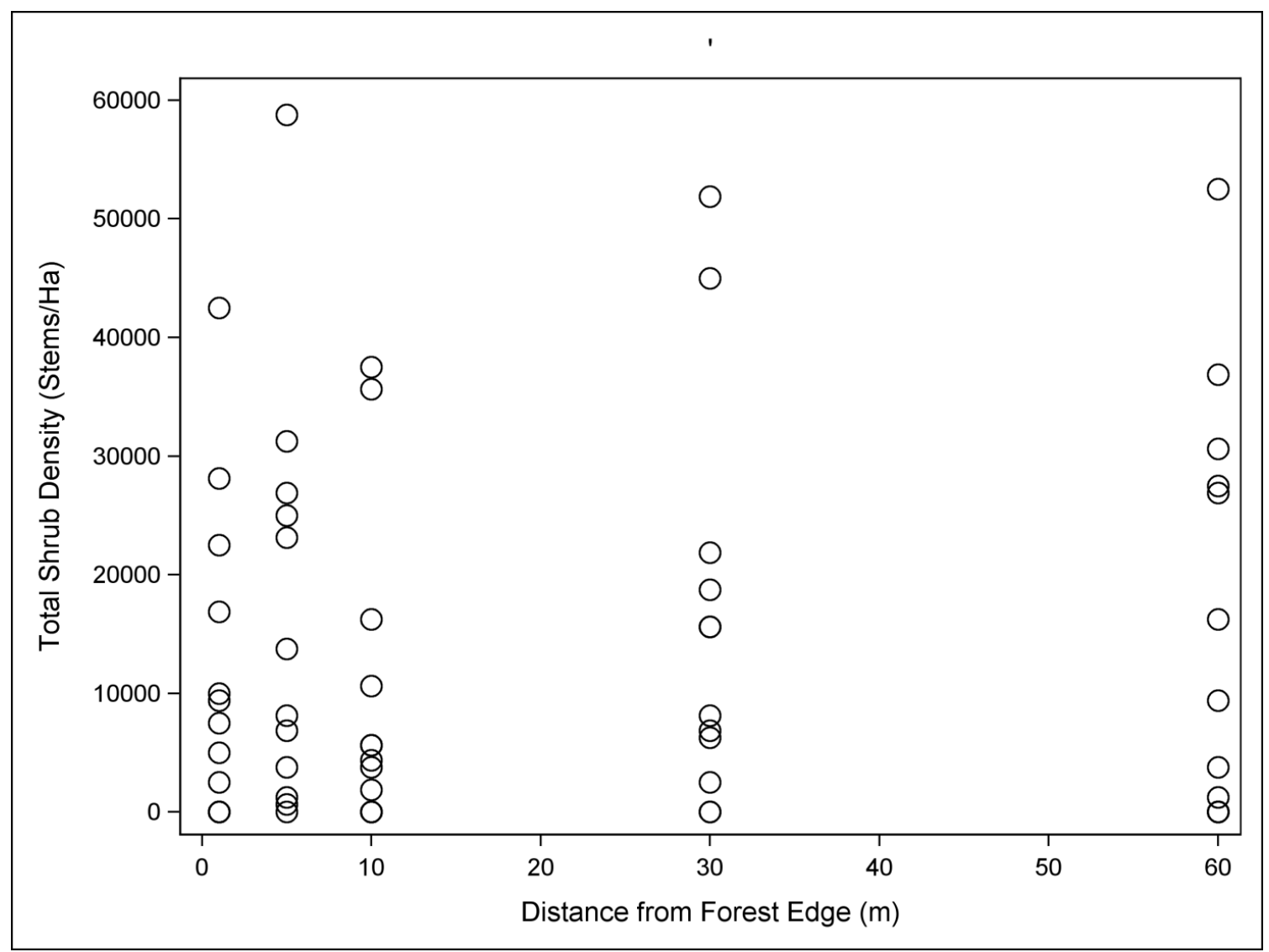

Appendix Figure 7. Total shrub stem density (stems/Ha) vs. distance from forest edge. Each data point represents the mean shrub density in a transect at 1, 5, 10, 30 or 60 meters from the forest edge. Data from all 60 transects ( 20 per site) is included. 


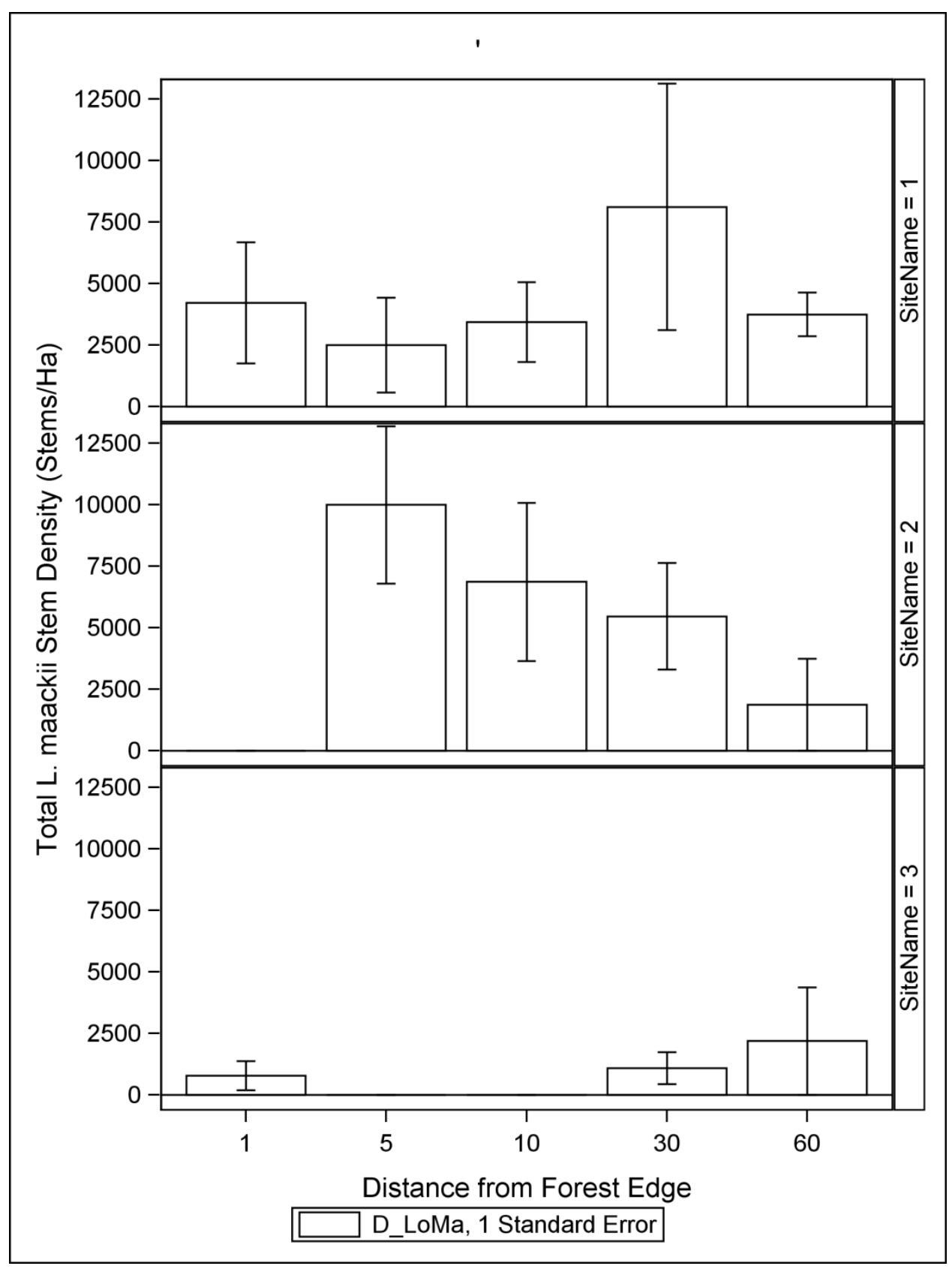

Appendix Figure 8. Total stem density of Lonicera maackii shrubs with distance from the forest edge at all three research sites. Each bar represents the mean shrub density of L. maackii stems at four transects per site, corresponding to 1, 5, 10, 30 or 60 meters from the forest edge. Sites 1, 2 and 3 refer to the dry, intermediate, and wet sites, respectively. Error bars are $\pm 1 \mathrm{SE}$. 


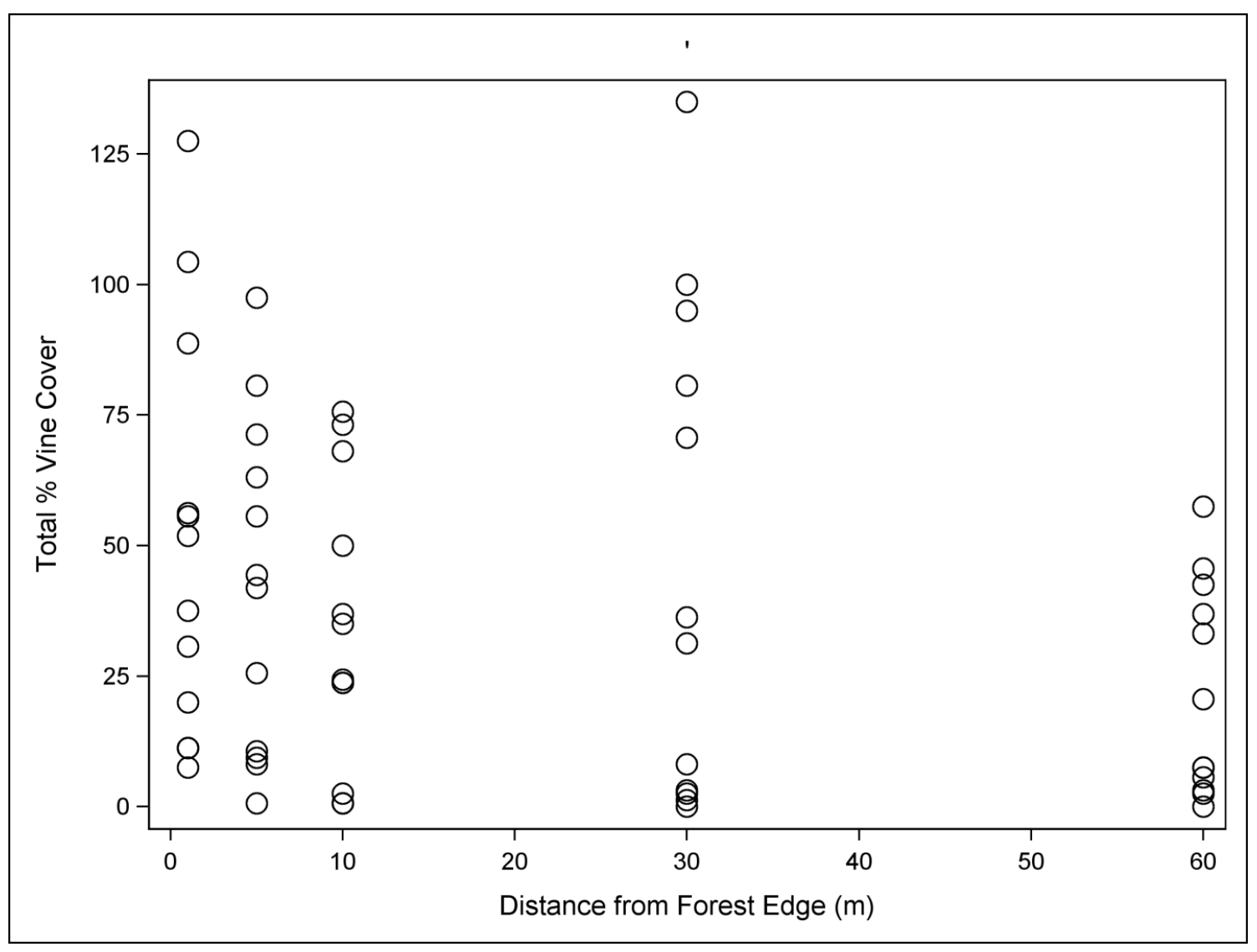

Appendix Figure 9. Total percent vine cover vs. distance from forest edge. Each data point represents the mean vine cover in a transect at 1, 5, 10, 30 or 60 meters from the forest edge. Data from all 60 transects (20 per site) is included. 


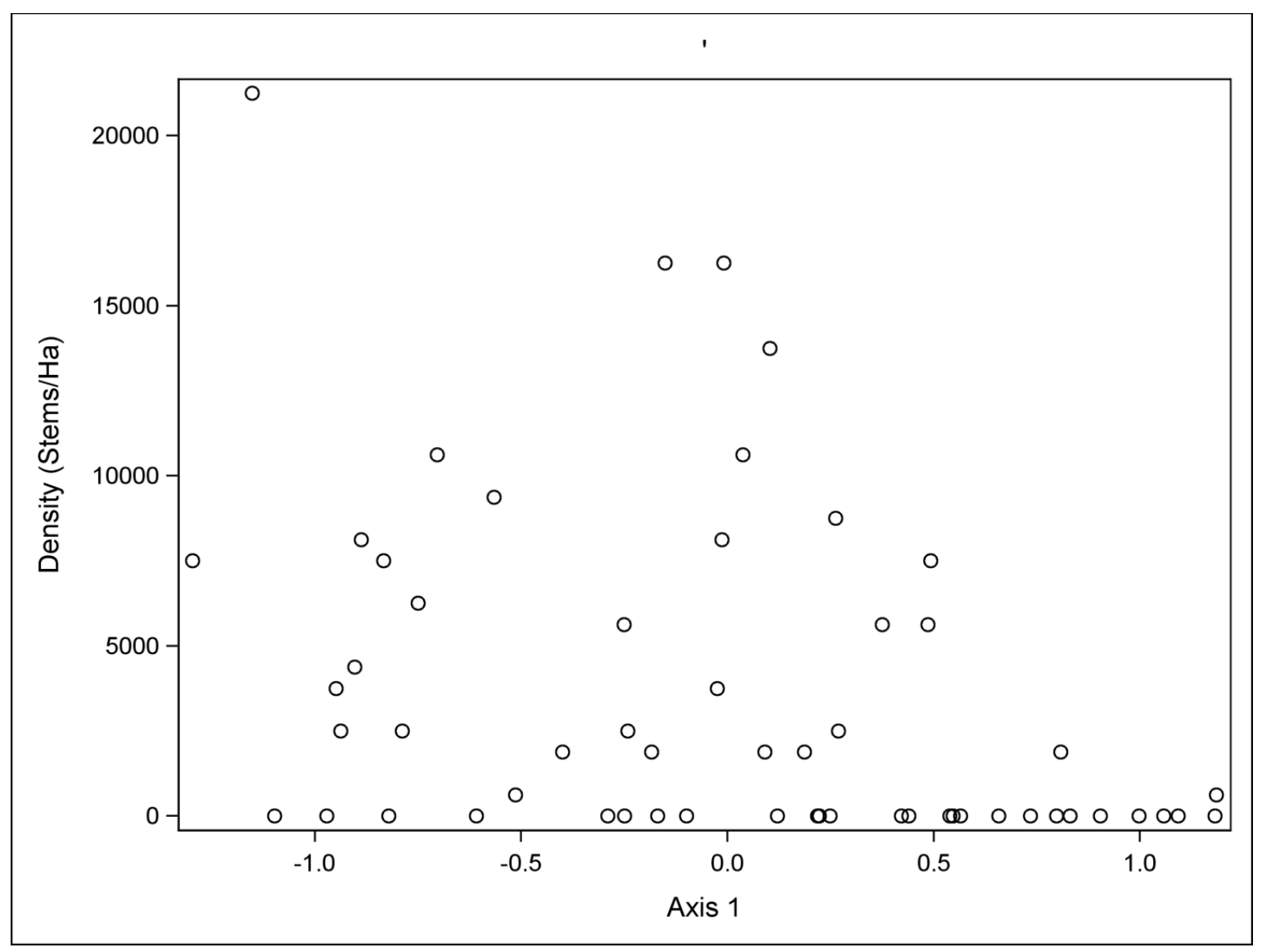

Appendix Figure 10. Density of Lonicera maackii plotted against values of Axis 1 for all transects that were included in the NMS ordination of woody plants species data at all sites. Note that the value zero for Axis 1 is in the center of the $\mathrm{x}$-axis. Axis 1 was positively related to days flooded. 


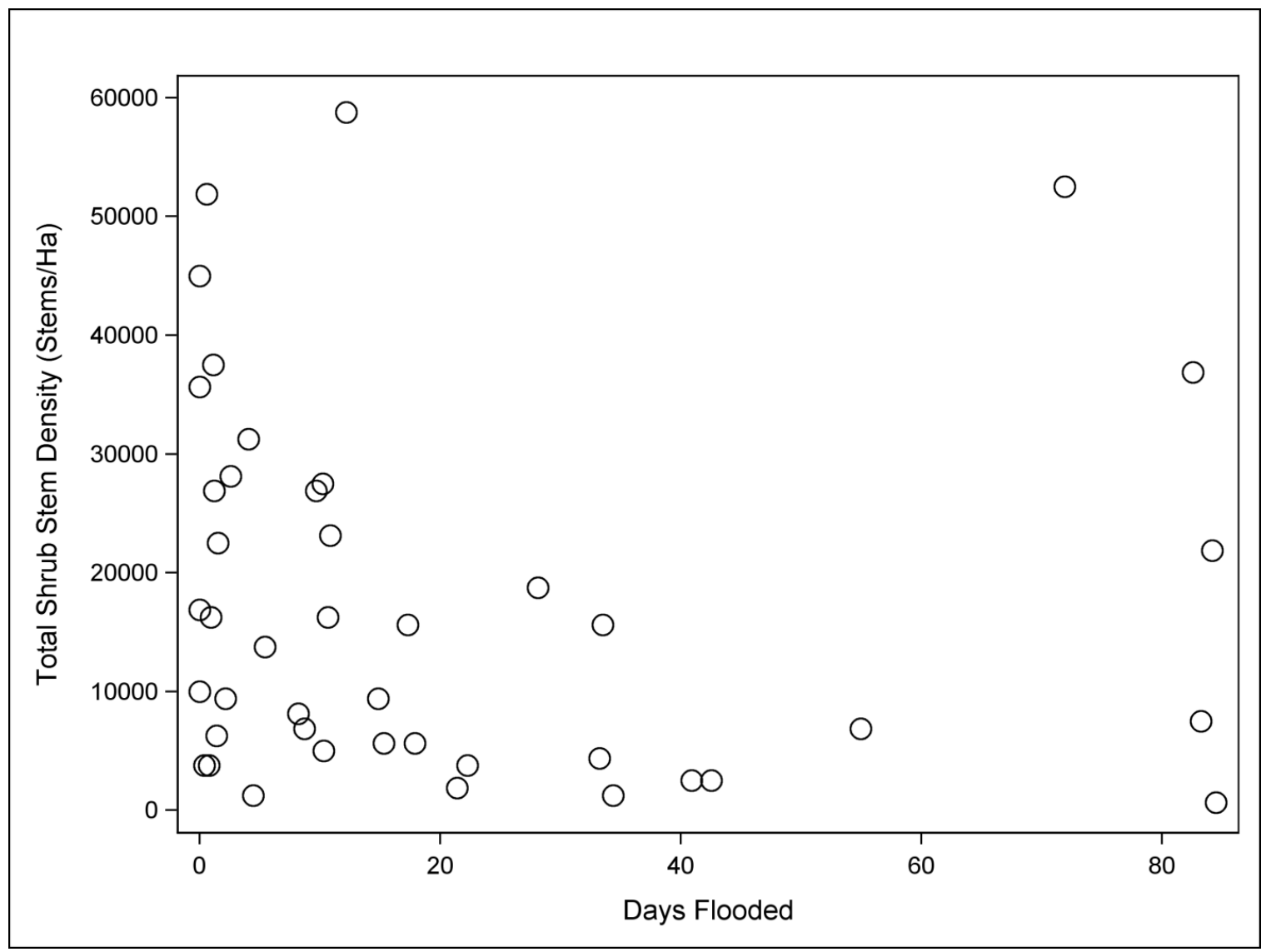

Appendix Figure 11. Total shrub stem density as it relates to the number of days flooded in the 55 transects where flooding was estimated. Only data points where values of total stem density were greater than zero are shown. 


\title{
CURRICULUM VITAE
}

\author{
Meghan Langley \\ Department of Biology \\ Life Sciences 139 \\ University of Louisville \\ Louisville, KY 40202
}

August 14, 1982

\section{EDUCATION}

B.S Biology, Centre College, 2004. Graduated cum laude.

\section{PROFESSIONAL POSITIONS}

Supplementary Instruction (SI) Leader and Peer Mentor. REACH Center, University of Louisville, Louisville, Kentucky. 8/2012-12/2012.

Graduate Teaching Assistant. REACH Center, University of Louisville, Louisville, Kentucky. 8/2011-5/2012.

Graduate Teaching Assistant. University of Louisville, Department of Biology, Louisville, KY. 8/2006-8/2011.

Student Conservation Association (SCA) Conservation Intern. U.S. Fish and Wildlife Service, Ecological Services and Fisheries Field Office, Panama City, Florida. 4/2005-4/2006.

\section{SCHOLASTIC AND PROFESSIONAL HONORS}

Student Research Grant, 2010. Awarded by the International Society of Wetland Scientists. Bernadine Meyer Memorial Scholarship, 2009. Awarded by Kentucky Natural History Society. Type 1 Travel Grant, 2008. Awarded by The Wetland Foundation.

Beechmont Garden Club Award, 2008. Awarded by University of Louisville, Biology Department.

Woody Boebinger Memorial Scholarship, 2007. Awarded by Kentucky Natural History Society. John C. Young Research Scholar, 2010. Centre College, Danville, Kentucky. Omicron Delta Kappa, 2004. Inducted for exceptional leadership skills.

Research Experience for Undergraduates Funding Recipient, 2002. Awarded by the National Science Foundation. 


\section{LEADERSHIP POSITIONS}

President, Biology Graduate Student Association. University of Louisville, Louisville, Kentucky. $8 / 10-8 / 11$.

Vice-President/Treasurer, Biology Graduate Student Association. University of Louisville, Louisville, Kentucky. 8/9-8/10.

\section{PRESENTATIONS}

Effects of flooding duration, depth, and simulated canopy closure on the growth and survival of the invasive shrub Lonicera maackii (Rupr.) Herder. Ecological Society of America, Annual Meeting, 2011, Austin, TX. (Oral Presentation).

Effects of flooding duration, depth, and simulated canopy closure on the growth and survival of Lonicera maackii (Rupr.) Herder. Meghan R. Langley, Kaycee E. Stone and Margaret M. Carreiro. Kentucky Academy of Sciences Annual Meeting, 2010, Bowling Green, KY. (Poster Presentation). 